Presented to:

The United States Department of Energy

\title{
Biomass Gasification Combined Cycle DE-FC36-96GO10173
}

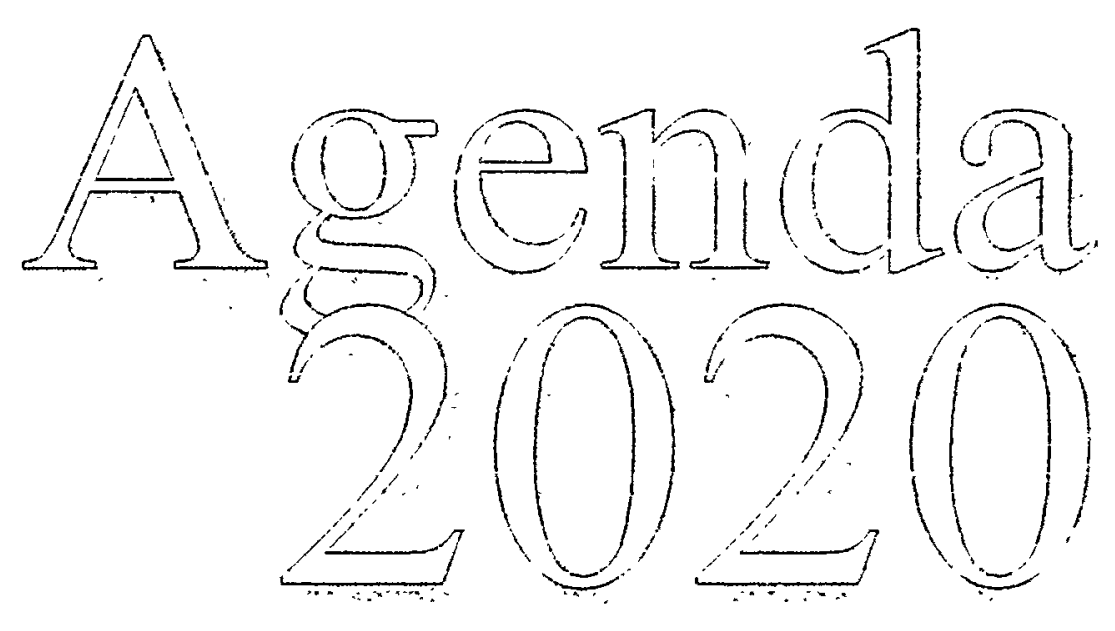

Submitted by: 


\section{DISCLAIMER}

This report was prepared as an account of work sponsored by an agency of the United States Government. Neither the United States Government nor any agency thereof, nor any of their employees, make any warranty, express or implied, or assumes any legal liability or responsibility for the accuracy, completeness, or usefulness of any information, apparatus, product, or process disclosed, or represents that its use would not infringe privately owned rights. Reference herein to any specific commercial product, process, or service by trade name, trademark, manufacturer, or otherwise does not necessarily constitute or imply its endorsement, recommendation, or favoring by the United States Government or any agency thereof. The views and opinions of authors expressed herein do not necessarily state or reflect those of the United States Government or any agency thereof. 


\section{DISCLAIMER}

Portions of this document may be illegible in electronic image products. Images are produced from the best available original document. 


\section{BIOMASS GASIFICATION COMBINED CYCLE DE-FC36-96G010173}

Final Report, July, 2000

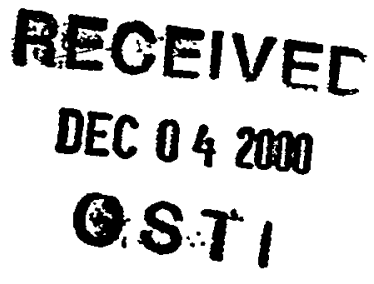

Prepared by:

Weyerhaeuser Company

32901 Weyerhaeuser Way

Federal Way WA 98003

Principal Investigator: Del Raymond

Valued Contributors:

James Lincoln, Senior Project Engineer, Weyerhaeuser Judith Kieffer, Contract Administration, Weyerhaeuser

Dave Davidson, Raw Materials Consultant, Weyerhaeuser

Robert Campbell, So. Forestry Project Manager, Weyerhaeuser

Bill Koos, New Bern Project Engineer, Weyerhaeuser

Terry Adams, Weyerhaeuser Consultant

Ron McKinsey, Nexant (previously with Bechtel International)

Tom Vivenzio, Stone \& Webster Engineering Corporation

Prepared for:

U.S. Department of Energy

Technical Monitor: James Spaeth, Bob Martin 


\section{Disclaimer of Warranties and Limitation of Liabilities}

This report was prepared by the organizations named below as an account of work sponsored by the Department of Energy, Office of Industrial Technologies. Neither of the organizations named below, nor any person acting on behalf of any of them:

A) Makes any warranty or representation whatsoever, expressed or implied, (I) with respect to the use of any information, apparatus, method, process, or similar items disclosed in this report, including merchantability and fitness for a particular purpose, or (II) that such use does not infringe on or interfere with privately owned rights, including any party's intellectual property, or (III) that this report is suitable to any particular user's circumstance; or

B) Assumes responsibility for any damages or other liability whatsoever (including any consequential damages, even if the organizations named below have been advised of the possibility of such damages) resulting from your selection or use of this report or any information, apparatus, method, process, or similar item disclosed in this report.

Organizations that prepared this report:

Weyerhaeuser Company

Stone \& Webster Engineering Corporation

Bechtel International 


\section{Executive Summary}

Biomass and black liquor gasification have been viewed by the forest products industry as important and beneficial technologies for nearly three decades. The U.S. Department of Energy and the industry have committed substantial resources to the development and demonstration of these technologies over this time period.

By the early 1990s, the results of these efforts appeared to be bringing both biomass and black liquor technologies to the point of commercial reality. Weyerhaeuser has been an industrial leader in the promotion of gasification throughout the period. The company has piloted black liquor technologies at its mill in New Bern, North Carolina, and operated the world's first commercial black liquor gasification unit at that facility.

The industry vision of the powerhouse of the future will necessitate both black liquor and wood residual gasification; and in the early 1990s, Weyerhaeuser proposed and received a grant from the Department of Energy to look at the feasibility of a wood residual gasifieralso at the New Bern facility. The results of that study, published in June 1995, indicated that in an electric power value situation of $\$ 0.05 / \mathrm{kWh}$ and above, a biomass gasification combined cycle project could potentially be attractive.

A further DOE grant was pursued, a biomass gasification technology was chosen, and the design and economics of both a New Bern specific and a generic gasification facility were developed, which is the subject of this report.

The project began in late 1996. It was originally envisioned to have a 12-18 month life with a goal of producing a design and engineering estimate for proceeding to construction and operation at either the New Bern facility or another facility, to be selected either inside or outside of Weyerhaeuser. The technology of choice was the Battelle/FERCO Low Inlet Velocity Gasification (LIVG) technology. It was selected because it operates at close to atmospheric pressure, produces a medium as opposed to a low Btu gas, is somewhat forgiving of variability in feedstock, and was believed to have the possibility of lower capital cost than other competing technologies.

The economic equation for an application at New Bern was driven by the belief that:

- A new power boiler would soon be necessary

- The opportunity to export power at prices in excess of $\$ 0.05 / \mathrm{kWh}$ would likely be in place for the foreseeable future

- Oil, on which the mill depends for its non-recovery fuel, would remain in excess of $\$ 20 / \mathrm{bbl}$ and trend upward at a higher rate than inflation

- The demonstration facility being built by FERCO at Burlington, Vermont, would provide the database for reducing capital costs and understanding both process performance and operating economics

Since the initiation of the project in late 1996, the Burlington facility has been significantly delayed as a result of both technical and program funding issues. The price of oil to the New Bern facility has fluctuated widely, and the process of electrical deregulation has created 
uncertainty with respect to power prices. In addition, in order to meet the powerhouse demands of the New Bern mill, a new power boiler has been installed. A detailed discussion of the unique factors surrounding a project at New Bern is found beginning on page § 8-21.

All of this resulted in eliminating biomass gasification as an option for New Bern in the near future. Therefore, to capture the greatest value possible from the extensive work already undertaken in this project, the scope of work was altered-with the concurrence of the DOE_-to focus on the process design, operating economics and public policy factors that would support a commercially viable biomass gasification project.

This report looks at the realities of raw material availability in eastern North Carolina and concludes that sufficient material is available for the size project considered here (236,200 BDT/year) at an average price of $\$ 18 / \mathrm{BDT}$. Further, producing an energy crop while utilizing nutrients from municipal wastewater was investigated with preliminary conclusions that such application could, in fact, be feasible and does potentially increase fiber production on a site of the kind investigated.

The gasification island design and cost is dealt with in depth, with the significant finding that feedstock drying technology integration is perhaps the most important capital and operating cost opportunity for design optimization. Further, a steam as opposed to a flue gas dryer, may be uniquely suited for integration with the gasification technology considered.

The integration of the gasifier island with a pulp mill is dealt with in detail using the New Bern facility as a real-life example. Nth Plant, Next Plant and Generic Nth Plant capital cost estimates are reported.

Utilization of medium Btu syngas from biomass is discussed with a conclusion that the impact of firing this gas in either a boiler or a lime kiln should be modest, with potential for positive environmental implications.

Finally, the last two sections of the report deal with the economic and public policy factors that would support the initial construction and operation of the first few gasification facilities and later support the sustainability of the technology as broadly applied across the industry. It appears from this analysis that the conclusion of the 1995 report-namely, that at a power value of $\$ 0.05 / \mathrm{kWh}$ or more with reasonable wood costs of $\$ 20 / \mathrm{BDT}$ or less and fossil fuel replacement value of $\$ 3.00 / \mathrm{Btu}$ or more - a mature gasification technology is likely to be economically sustainable given that a facility considering this technology is at the point of needing to replace or significantly upgrade existing powerhouse facilities.

A discussion of the relationship of this work to that reported in 1995 begins on page $\S 8-18$. It should be pointed out that in the 1995 study the concept included export power sales and therefore was significantly more influenced by power value than the current effort.

Given the current state of development, the report concludes that to nurture the technology to maturity and get the first full commercial units in place will require:

- unique site characteristics of very low raw material costs, fossil fuel prices in excess of $\$ 3.00 / \mathrm{MBtu}$ and power values in excess of $\$ 0.05 / \mathrm{kWh}$; and $/$ or

- $\quad$ significant public policy changes on the order of a $\$ 0.50 / \mathrm{MBtu}$ or greater fuel gas tax credit, a $\$ 25 /$ ton avoided atmospheric carbon emissions credit, or some similar policy. 
An example of conditions that would produce favorable economics is found on page § 8-17, where a $\$ 24 / \mathrm{bbl}$ oil price escalating at $1 \%$ real, biomass cost of $\$ 8 / \mathrm{BDT}$ and a $\$ 0.06 / \mathrm{kWh}$ power cost results in ROIs above $20 \%$.

The study strengthens the belief that the perceived benefits of the Battelle/FERCO technology-given a successful demonstration at the Burlington, VT, facility-are real. It is hoped that this study provides the design and economic basis for a demonstration project that has the site characteristics essential for commercial success and will enhance and improve the efficiency of such project development.

Weyerhaeuser would like to recognize with special thanks the Department of Energy for their financial support of this project, FERCO for the cooperation and essential information provided, Bechtel and Stone \& Webster Corporation for the professionalism of their engineering services and NREL — particularly, Dr. Ralph Overend-for his willingness to review and provide insight. 


\section{CONTENTS}

1.0 Background and Introduction ................................................. 1-1

$1.1 \quad$ Putting Gasification in Context ......................................................1-1

1.2 Brief History of Gasification Interest in the Forest Products Industry ......................................................1-1

1.3 Summary of Recent Weyerhaeuser Activities in Gasification ............1-1

1.4 Opportunity at the New Bern Mill ...................................................1-2

1.5 Current DOE/Weyerhaeuser Project.................................................. 1-2

1.6 The formation and Purpose of the Forest Products Gasification Initiative .......................................................................... 1-3

1.7 The Organization of This Report.................................................1-4

2.0 Raw Material Availability .......................................................... 2-1

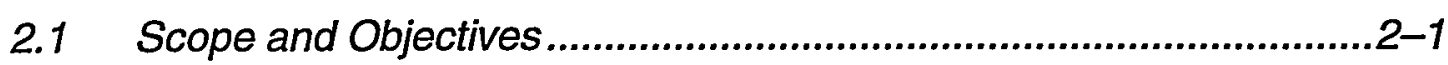

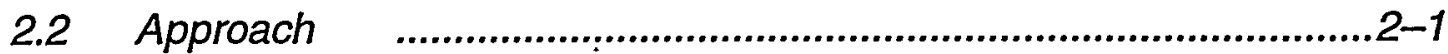

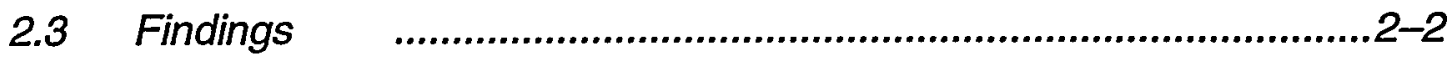

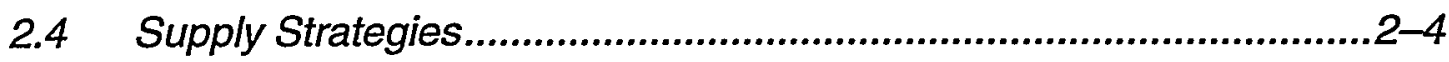

2.4.1 Capture Existing Volumes at Hog Fuel Values.......................2-4

2.4.2 Incorporate Mill Residuals Currently Going to Landfill.............2-7

2.4.3 Capture Existing Residuals at Hog Fuel Prices Plus Transportation ..............................................................2-8

2.4.4 Grow Biomass by Maximizing Pine Volumes ........................2-12

2.4.5 Grow Maximum Pine/Hardwood per Acre ...........................2-13

2.4.6 Dedicated Short Rotation Plantation ....................................2-14

\subsection{Energy Crop Possibilities.................................................... 3-1}

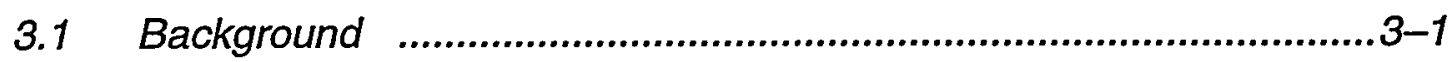

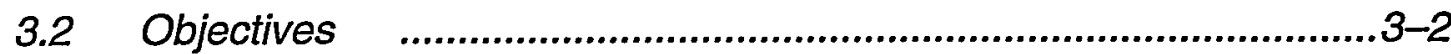

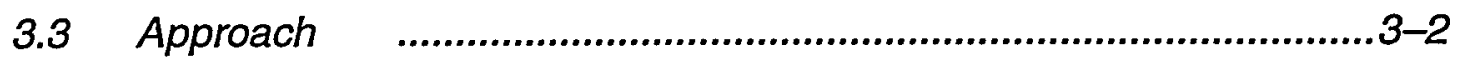

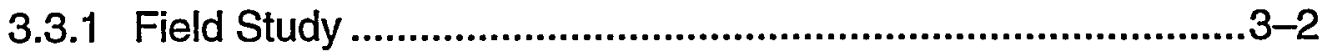

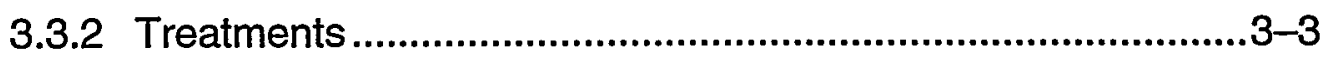

3.3.3 Application Systems ............................................................3-3 
3.3.4 Plot Layout ....................................................................................

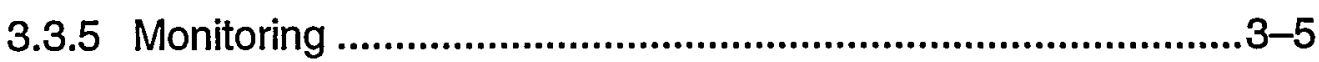

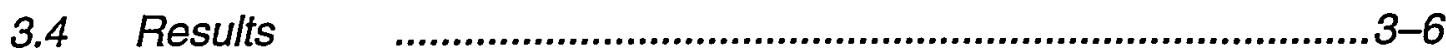

3.4.1 Tree Measurements ...............................................................3-6

3.4.2 Pine Foliage ...........................................................................

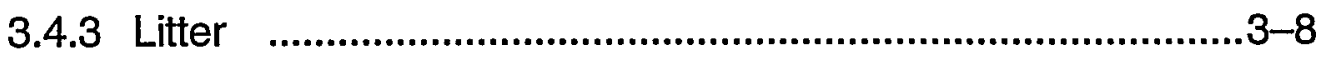

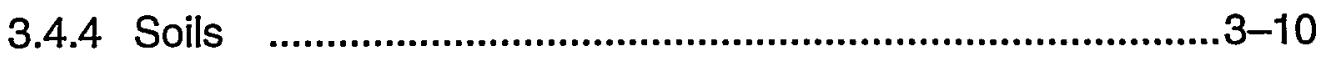

3.4.5 Surface Water ....................................................................10

3.4.6 Ground Water.......................................................................

3.4.7 Understory Vegetation.........................................................3-11

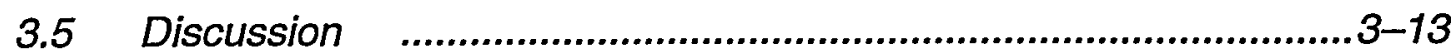

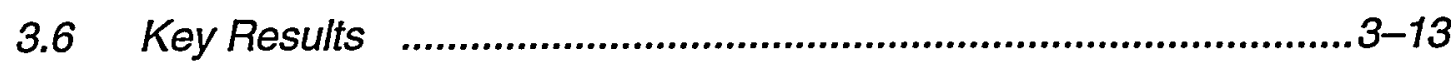

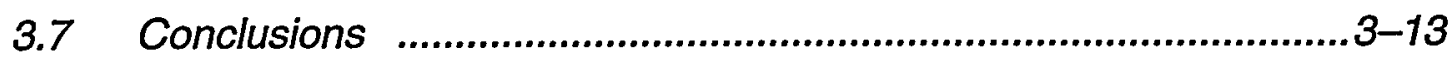

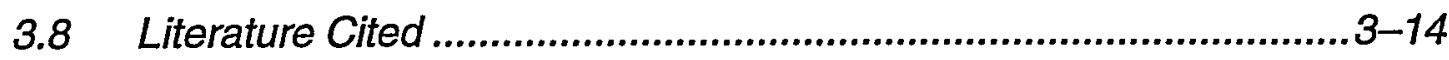

4.0 Gasifier Island Design \& Cost ............................................. 4-1

4.1 Approach to Cost/Performance Analysis ........................................4-1

4.2 New Bern Specifications \& Design Basis.......................................4-2

4.2.1 General Criteria ......................................................................4-2

4.2.2 Site-related Conditions .......................................................4-2

4.2.3 Meteorological Data ..............................................................4-2

4.2.4 Technical Data ......................................................................

4.2.5 Capital Cost Criteria ..............................................................4-4

4.2.6 Qualifications.........................................................................4-4

4.2.7 Direct Field Material Costs ....................................................4-5

4.2.8 Direct Field Labor Costs.....................................................4-5

4.2.9 Direct Subcontract Costs......................................................4-5

4.2.10 Indirect Field and Home Office Engineering Costs..................4-5

4.3 Plant Description........................................................................6

4.3.1 Fuel Feed and Drying System ................................................4-6

4.3.2 Gasifier/Combustor System ...................................................4-7

4.3.3 Product Gas Clean-up System ...........................................4-9 
4.4 Significant Findings.................................................................4-14

4.4.1 Dryer Type ............................................................................ $4-14$

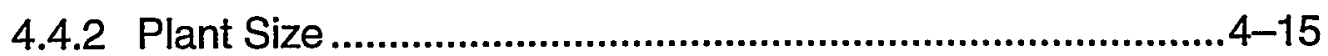

4.4.3 Feed Moisture ................................................................... 46

4.5 Implications to Future Designs......................................................4-18

4.6 Areas of Significant Impact on Economics.....................................4-19

4.6.1 Drying Technology Integration .........................................4-19

4.6.2 Fluidizing Gas Selection..................................................4-20

4.6.3 Dryer Product Moisture .........................................................4-20

4.6.4 Capital and Operating Cost Tradeoffs ...............................4-20

4.7 Capital Cost Estimating Approach .................................................4-20

4.8 Detailed Capital Costs ..................................................................4-21

4.9 Capital Cost Result Summary ........................................................4-23

5.0 Pulp Mill Integration Design \& Cost .................................. 5-1

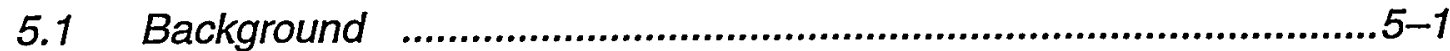

5.2 Integration Design Basis ..................................................................

5.3 Balance of Plant System Descriptions ..........................................5-4

5.3.1 Wood Receiving, Storage and Handling System....................5-4 5.3.1.1 Equipment List ................................................5-5

5.3.2 Ash Collection and Removal System ...................................5-8 5.3.2.1 Equipment List ...............................................5-8

5.3.3 Product Gas System ...........................................................5-11

5.3.3.1 Equipment List..............................................5-12

5.3.4 Condensing Steam Turbine System..................................5-14

5.3.4.1 Equipment List..........................................5-14

5.3.5 Cooling Water System.......................................................5-16

5.3.5.1 Equipment List..............................................5-16

5.3.6 Other Utility/Infrastructure Requirements ..........................5-18

5.3.6.1 Nitrogen System ...........................................5-18

5.3.6.2 Instrument Air ................................................5-18

5.3.6.3 Process Water Make-up to

Gasification Plant \& New Cooling Tower .........5-18

5.3.6.4 Boiler Feedwater Make-up to

Gasification Plant..........................................5-18 
5.4 Capital Cost Estimates

5.4.1 Estimating Approach $5-23$

5.4.2 Estimating Basis and Assumptions $5-23$

5.4.3 Estimate Components $5-24$

5.4.3.1

Direct Field Material Costs

$5-24$

5.4.3.2

Direct Field Labor Costs $5-24$

5.4 .3 .3

Direct Subcontract Costs .5-24

5.4.3.4

Indirect Field and Home Office

Engineering Costs $5-25$

5.4 .3 .5

Process Contingency .5-25

5.4.3.6

Project Contingency

5.4.4 Nth Plant Design at New Bern Cost Estimate $5-26$

5.4.5 Next Plant Design at New Bern Cost Estimate. $5-26$

5.4.6 Generic Nth Plant Gasification Plant Cost Estimate $5-27$

5.5 Operating \& Maintenance Costs $5-27$

5.5.1 Staffing Requirements. $5-27$

6.0 Syngas Utilization Considerations 6-1

6.1 Process Impacts of MCVG. $6-1$

7.0 Power Boiler Relifing as a Conventional Alternative 7-1

7.1 Background 7-1

7.2 Design Basis 7-2

7.3 System Descriptions . $7-5$

7.3.1 Boiler/Flue Gas System Modifications 
7.3.2 Condensing Steam Turbine System.....................................7-8

7.3.2.1 Equipment List.................................................7-8

7.3.3 Wood Handling System ........................................................7-10

7.3.3.1 Equipment List...............................................

7.3.4 Ash Handling System ......................................................7-12

7.3.4.1 Equipment List .............................................7-12

7.3.5 Cooling Water System.......................................................7-15

7.3.5.1 Equipment List............................................

7.3.6 Other Utility/Infrastructure Requirements ...........................7-17

7.4 Capital Cost Estimate .................................................................

7.4.1 Estimate Approach ............................................................7-17

7.4.2 Estimating Basis and Assumptions ....................................7-18

7.4.3 Estimate Components.....................................................7-19

7.4.3.1 Direct Field Material Costs...............................7-19

7.4.3.2 Direct Field Labor Costs ..................................7-19

7.4.3.3 Direct Subcontract Costs .................................7-19

7.4.3.4 Indirect Field and Home Office

Engineering Costs .........................................7-19

7.4.3.5 Contingency................................................

7.5 Boiler Relifing Project Cost Estimate ........................................... 7-20

7.6 Operating \& Maintenance Costs ................................................. 7-20

7.6.1 Staffing Requirements....................................................7-20

8.0 Economics of New Bern Alternatives..................................... 8-1

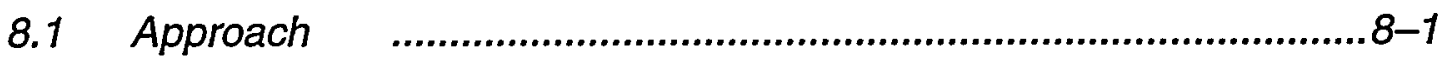

8.2 Overview of Alternatives .................................................................

8.3 Analytical Method, Assumptions and Key Inputs ..............................8-2

8.4 Results and Discussion................................................................8-4

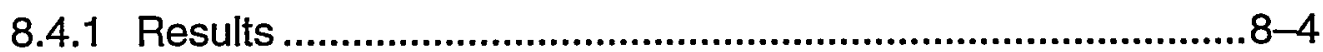

8.4.2 Discussion - Comparison to BGCC Technology ................. 8-18

8.5 Conclusions: New Bern Gasification Project Economic Analysis....8-21 


\subsection{Public Policy \& Sustainable Economic Considerations ...... 9-1}

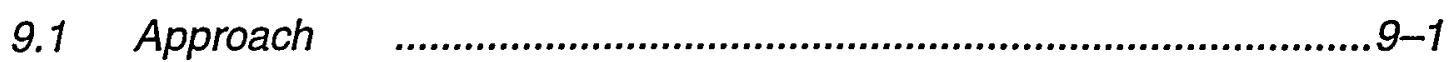

9.2 Overview of Alternatives .............................................................2

9.3 Analytical Method, Assumptions and Key Inputs .............................9-3

9.4 Results and Discussion: Generic LIVG Process Economics.............9-4

9.4.1 Economic Assumptions .....................................................9-4

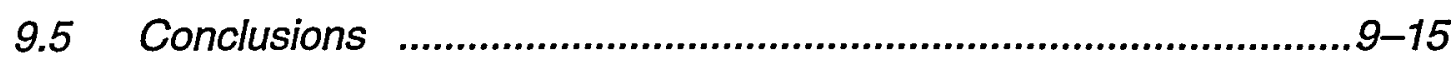

10.0 Overall Conclusions ..............................................................10-1 


\section{LIST OF TABLES}

2-1 Total Biomass Fuel Resource (kBDT/year)

2-2 Weyerhaeuser Mill Residuals by Fuel Cost

2-3 Non-Weyerhaeuser Mill Residuals (\$/BDT)

2-4 Non-Weyerhaeuser Mill Residuals by Distance from New Bern

2-5 Weyerhaeuser Forest Residuals - kBDT

2-6 First Thinning Residuals

2-7 Inter-row Planting - 450 to 800 trees/acre

2-8 Short Rotation Pine Plantation

3-1-A Loblolly pine measurement of height ( $\mathrm{ft}$ ) and $\mathrm{dbh}$ (in) by treatment level and application

3-1-B Loblolly pine growth as measured by change in height (ft) and dbh (in) and presented by treatment level and application method on Craven 26 fertigation study

3-1-C Loblolly pine measurements and growth by $\mathrm{D}^{2} \mathrm{H}\left(\mathrm{ft}^{3}\right)$ on Craven 26 fertigation study

3-2 Loblolly pine foliar nutrient content on Craven 26 fertigation study

3-3-A Loblolly pine litter nutrient content on Craven 26 fertigation study

3-3-B Other litter nutrient concentration on Craven 26 fertigation study

3-4 Soil nutrient concentrations on Craven 26 fertigation study

3-5 Surface (riser) water nutrient concentration on Craven 26 fertigation study

3-6 Ground (well) water nutrient concentration on Craven 26 fertigation study

3-7-A Understory grass vegetation nutrient content on Craven 26 fertigation study

3-7-B Understory grass vegetation nutrient concentration on Craven 26 fertigation study

4-1 Design Biomass Feed Analysis

4-2 Design Biomass Size, Williams Classification

4-3 Design Biomass Source Distribution

4-4 Typical Product Gas Analysis, Dry Basis

4-5 Major Process Flow Streams - Weyerhaeuser/LIVG Gasifier

4-6 Total Plant Cost for an Nth Plant (New Bern) by System (January $1999 \mathrm{k} \$$ )

4-7 Total Plant Cost for First-of-a-Kind Plant (New Bern) (1999 k\$) 
5-1 Product Gas Composition

5-2 Required Modifications to Utilize Product Gas

5-3 Gasification Project Electrical Load List

5-4 Biomass Gasification Retrofit Project Capital Cost Estimate - Nth Plant Design

5-5 Biomass Gasification Retrofit Project Capital Cost Estimate - Next Plant Design

5-6 Biomass Gasification Retrofit Project Capital Cost Estimate - Nth Plant Design Generic Application

6-1 Process Impacts of MCVG

7-1 Relifed Boiler Expected Performance

7-2 Performance at Reduced Loads

7-3 Additional Electric Loads

7-4 No. 1 Power Boiler Relifing Project Capital Cost Estimate

8-1 Overview of Project Alternatives

8-2 Summary of Default Economic Assumptions (New Bern Alternatives Case)

8-3 Escalation Factors for Economic Viability

8-4 Public Policy Incentives - Levels for New Bern Gasifier Project Economic Viability

8-5 Economic Value as a Function of Economic Assumptions

8-6 Performance Parameters for BGCC Technology Comparison

8-7 Supportable Capital Summary for New Bern Biomass Options

9-1 Overview of the Generic LIVG Project

9-2 Summary of Default Economic Assumptions (Generic Case)

9-3 Supportable Capital Summary

9-4 Level of Public Policy Incentive to Reach Threshold Rate of Return 


\section{LIST OF FIGURES}

Figure 2-1 Residual Biomass Fuel Resources

Figure 2-2 Total Biomass Fuel Resource

Figure 2-3 Map of External Forest Residuals

Figure 2-4 Map of Total Mill Residuals

Figure 3-1 Schematic of Irrigation Hose Application Method

Figure 3-2 Schematic of Reel Rain Traveler Irrigation System

Figure 4-1 Feed Preparation

Figure 4-2 Gasification/Combustion

Figure 4-3 Product Gas Clean-up

Figure 4-4 Steam to Gasifier

Figure 4-5 Sand Circulation

Figure 4-6 Cold Gas Efficiency

Figure 4-7 Overall Efficiency

Figure 5-1 Gasification Project Site Plan

Figure 5-2 Biomass Feedstock Handling System

Figure 5-3 Ash Collection \& Removal Flow Diagram

Figure 5-4 Product Gas System Flow Diagram

Figure 5-5 Condensing Steam Turbine Flow Diagram

Figure 5-6 Circulating Water Flow Diagram

Figure 5-7 Gasifier Steam System Flow Diagram

Figure 7-1 Power Boiler Relifing Site Plan

Figure 7-2 Boiler/Flue Gas System Modifications

Figure 7-3 Condensing Steam Turbine Flow Diagram

Figure 7-4 No. 1 Power Boiler Wood Handling System

Figure 7-5 No. 1 Power Boiler Ash Handling Flow Diagram

Figure 7-6 No. 1 Power Boiler Circulating Water Flow Diagram

Figure 8-1 Impact of Fossil Fuel Cost \& Escalation on Return on Investment

Figure 8-2 Impact of Fossil Fuel Cost \& Escalation on Net Present Value

Figure 8-3 Impact of Average Biomass Fuel Cost on Return on Investment

Figure 8-4 Impact of Average Biomass Fuel Cost on Net Present Value 
Figure 8-5 Impact of Displaced Purchased Power Value on Return on Investment

Figure 8-6 Impact of Displaced Purchased Power Value on Net Present Value

Figure 8-7 Impact of Maintenance Cost Assumptions on Return on Investment

Figure 8-8 Impact of Maintenance Cost Assumptions on Net Present Value

Figure 8-9 Comparison with No. 1 Power Boiler Relifing Project - Return on Investment

Figure 8-10 Comparison with No. 1 Power Boiler Relifing Project - Net Present Value

Figure 8-11 Impact of Fuel Gas Tax Credit on Return on Investment

Figure 8-12 Impact of Fuel Gas Tax Credit on Net Present Value

Figure 8-13 Impact of Tax Credits for Avoided Carbon Emissions on Return on Investment

Figure 8-14 Impact of Tax Credits for Avoided Carbon Emissions on Net Present Value

Figure 8-15 Impact of Favorable Economic Assumptions on Return on Investment

Figure 8-16 Impact of Favorable Economic Assumptions on Net Present Value

Figure 8-17 New Bern DOE Study Options vs. Tampella BGCC/LOI Study - Return on Investment

Figure 8-18 New Bern DOE Options vs. Tampella BGCC - Net Present Value

Figure 9-1 Impact of Fossil Fuel Cost on Return on Investment (Free Biomass)

Figure 9-2 Impact of Fuel Costs on Net Present Value (Free Biomass)

Figure 9-3 Impact of Fossil Fuel Cost on Return on Investment (\$10/BDT Biomass)

Figure 9-4 Impact of Fuel Costs on Net Present Value (\$10/BDT Biomass)

Figure 9-5 Impact of Fossil Fuel Cost on Return on Investment (\$20/BDT Biomass)

Figure 9-6 Impact of Fuel Costs on Net Present Value (\$20/BDT Biomass)

Figure 9-7 Impact of Fossil Fuel Cost on Return on Investment (\$30/BDT Biomass)

Figure 9-8 Impact of Fuel Costs on Net Present Value (\$30/BDT Biomass)

Figure 9-9 Impact of Capacity Utilization on Return on Investment

Figure 9-10 Impact of Capacity Utilization on Net Present Value

Figure 9-11 Impact of Preferential Tax Treatment on Return on Investment

Figure 9-12 Impact of Preferential Tax Treatment on Net Present Value

Figure 9-13 Impact of Tax Credits for Avoided Carbon Emissions on Return on Investment

Figure 9-14 Impact of Tax Credits for Avoided Carbon Emissions on Net Present Value

Figure 9-15 Impact of Fuel Gas Tax Credit on Return on Investment

Figure 9-16 Impact of Fuel Gas Tax Credit on Net Present Value 


\section{Section 1}

\section{Background and Introduction}




\subsection{Background and Introduction}

\subsection{Putting Gasification in Context}

According to the Combined Heat \& Power Association, on average two-thirds of the fuel used to make electricity in the U.S. is wasted. The average efficiency of power generation has remained around 33\% since 1960. By utilizing the emerging technologies of gasification combined cycle, this percentage can be increased to levels of $70 \%$ and above.

Combined heat and power technologies have been practiced in the forest products industry for several decades, and this industry is currently the largest producer of energy from biomass in the world. By combining the efficiency gains offered by biomass gasification combined cycle with the renewable energy available through wood residuals and spent pulping liquors, the forest products industry has by far the greatest early opportunity to significantly impact the National goals of less dependence on foreign oil and reduced carbon emissions while at the same time increasing the industry's global competitiveness. In addition, BGCC technologies applied to spent pulping liquors also have benefits associated with pulp yield and quality. It is for these reasons that for many years the industry has had an interest in the development, commercialization and deployment of BGCC technologies.

\subsection{Brief History of Gasification Interest in the Forest Products Industry}

The gasification of carbonaceous feedstocks has been practiced successfully for well over 40 years. Beginning in the early 1970's, the forest products industry began to intensively study the potential opportunity of applying gasification technologies to its wood residuals, spent pulping liquors and solid wastes. This interest was driven by the realization that the technologies that had been in use for many years were inefficient, capitally intensive and had both safety and environmental issues. A landmark conference was undertaken in Sweden in 1976 where the world's alternatives to the processing of Kraft black liquor were discussed and the most promising selected for further development. At about this same time, the U.S. Department of Energy began to actively support research in the area of spent liquor and wood residual gasification. This industry/government partnership has evolved the most promising technologies to the point of large scale demonstrations.

\subsection{Summary of Recent Weyerhaeuser Activities in Gasification}

Weyerhaeuser's interest in gasification dates back to the mid-1970s, during which time technologists within the company evolved their own bubbling bed gasification concept and design. Near the end of the Carter administration in 1980, the company applied for and received a significant grant from the DOE in the gasification area. This grant was for the purpose of installing the Weyerhaeuser-designed gasifier on a lime kiln at its Everett, Washington, pulp mill.

As a result of a withdrawal of funds by the incoming Reagan administration, the project was never completed. However, the interest in gasification within Weyerhaeuser continued. 
In the early to mid 1980s, several studies were made focused on applying gasification technology in a number of the company's mills-including the evaluation of coal gasification at the Weyerhaeuser mill in Plymouth, North Carolina, biomass gasification at the Weyerhaeuser mill in Valliant, Oklahoma, and a study of the use of biomass gasification at the Weyerhaeuser mill in Springfield, Oregon. Although the results of these studies were encouraging, it was concluded that the technology was not sufficiently developed to effect a low-risk implementation.

In the late 1980s, the company turned its attention to black liquor gasification and worked with MTCI in the development of a novel black liquor technology. This effort ultimately resulted in a pilot plant being built and operated at the Weyerhaeuser New Bern, North Carolina, mill in 1994. The pilot plant was evolved from 1994-1995 and was operated successfully for a brief period of time in late 1995 .

At about the same time, the decision was made to construct a unit at the New Bern mill using a different black liquor technology. This technology, offered by Kvaerner Chemrec, was built and started operation in December of 1996. It is an atmospheric pressure technology designed for the purpose of providing incremental pulping capacity to the mill. The unit has been operated intermittently since that time, and a considerable amount of knowledge has been gained about the chemistry and physics of the operation as well as the materials of construction and refractories that will survive in the harsh environments created by black liquor.

\subsection{Opportunity at the New Bern Mill}

Since 1991, the New Bern mill has been unable to utilize internally-generated hog fuel in its power boiler and has operated with the use of \#6 oil. Consequently, there has been significant motivation to find an economically sustainable alternative to the use of oil in the power boiler and the lime kiln. As a result, Weyerhaeuser responded to the NREL Request for Proposals (LOI number RCA-3-13326) in July, 1993. The company also responded to a DOE Request for Proposals (DE-NPO2-93CH10566) in October, 1993; and most recently to the DOE program solicitation DE-PS36-95GO10052 aimed at biomass power for rural development. The company was fortunate to receive DOE grants in two of these attempts and has been working with the DOE on projects aimed at the New Bern mill opportunity since receiving the first grant in May of 1994.

The first of these studies-which was carried out with Stone \& Webster Engineering, Amoco Oil, EPRI and Carolina Power \& Light as partners-concluded that at export power prices in excess of $4-5 \phi / \mathrm{kWh}$, a biomass gasification combined cycle plant at a facility like New Bern should be economically attractive. It was this result that motivated the company to apply for the second grant, which was awarded in October, 1996. It is this project, entitled Biomass Gasification Combined Cycle, that is the subject of this report.

\subsection{Current DOE/Weyerhaeuser Project}

The technology of choice in this work has been the Battelle/FERCO Low Inlet Velocity gasification technology that is being demonstrated in a utility application in Burlington, Vermont. The reasons for choosing this technology included a belief that it would be more forgiving of feedstock variability, the unit operates without pressurization, it provides a 
medium as opposed to a low heating value gas and was anticipated to be lower in capital than many alternatives-particularly those that required pressurization. A significant part of the present work has been to verify whether or not these lower capital expectations were justified.

The Biomass Gasification Combined Cycle project had an original completion date of September, 1997, but was highly dependent on the information being developed at the Burlington demonstration facility. As a result of significant delays in the Burlington project, four time extensions were requested and approved. During this time period, the drivers that initially made the project look economically sustainable at New Bern underwent significant change. For example, the mill became significantly more thermally efficient and, until very recently, the anticipated price of oil has been much lower than the early economics assumed.

As a result of these and other factors, it was determined in the fist quarter of 1999 that an early implementation of the technology was unlikely at the New Bern location.

Consequently, a scope change was negotiated with the DOE that basically refocused the project on process improvements and capital cost reduction opportunities and eliminated the tasks associated with a detailed engineering cost estimate for implementation at New Bern. Even though the decision was made not to implement a biomass application at New Bern in the short term, interest in developing both biomass and black liquor gasification combined cycle technologies for use in other Weyerhaeuser locations remains strong.

\subsection{The Formation and Purpose of the Forest Products Industry Gasification Initiative}

The development of the Forest Products Industry technology vision in 1994 and its further refinement resulted in gasification combined cycle technologies being identified as a very high priority for the industry. In 1998, Weyerhaeuser joined forces with Georgia Pacific and Champion International to evolve an alliance of the industry entitled the Forest Products Industry Gasification Initiative. This initiative is broadly supported across the entire industry and recently Gaylord Container has joined the alliance as another potential host company for the early deployment of these technologies. This initiative is being overseen by the Agenda 2020 Chief Technology Officers Committee.

The motivation behind this initiative is the belief that the industry needs at least three different technologies in at least three different applications in order to take full advantage of a window of opportunity in the capital cycle, which is commencing now and will continue for the next 15-20 years. The goal that the alliance and Weyerhaeuser has in this initiative is to bring biomass and black liquor gasification combined cycle technologies to a stage of development that they will be available to the industry as commercially viable choices. If proven, these technologies offer great potential for improved capital effectiveness, energy efficiency, environmental performance, global competitiveness and safety. These advantages will be gained from:

- the ability to increase electrical power production capability by up to $300 \%$;

- providing the potential to positively impact green house gas emissions by over 30 million metric tons of carbon per year; 
- making available these technology options early enough for the majority of the U.S. forest products industry to utilize them in normal capital replacement decisions; and

- providing U.S. facilities with significantly more effective and efficient powerhouses compared to currently growing segments of the global industry, such as southeast Asia.

The three projects originally proposed were:

- Champion's Courtland, Alabama mill to demonstrate a full-scale pressurized, oxygenbased Kraft black liquor gasification system,

- Georgia Pacific's Big Island, Virginia mill to demonstrate semi-chem caustic/carbonate liquor gasification, and

- Weyerhaeuser's New Bern, North Carolina mill to demonstrate gasification of residual biomass.

Each of the three projects utilizes a different gasification technology in a different application. Choosing one technology over another to demonstrate on a sequential basis would result in a significant delay getting the technology to the marketplace for use by all segments of the industry. The combination of these three projects ensures that the broadest range of the pulp and paper industry will benefit from the proposed demonstrations. Each of the applications may be used separately, or may be combined for the highest level of benefits. Demonstrating them in different mill configurations ensures that, if proven, the technology will find broad market acceptance in a wide range of facilities in the industry-be it for replacement of current technology or for incremental new capacity.

Because of the age of the industry's powerhouses, these technologies need to be demonstrated in parallel if they are to be available in time for broad application across the industry. Due to the diversity of the industry's needs, no one technology can provide a full solution. Though the three technologies differ, there are fundamental issues of chemistry and physics that are common across each project. This can reinforce the robustness of the projects, reduce the risk of failure, and-in the event of a project delay or diminished success-provide an adaptable alternative.

By working through the American Forest \& Paper Association and with lobbyists from the involved companies, a line item in the Federal budget has been established to fund the initiative. In FY $1999, \$ 2 \mathrm{M}$ was provided to launch the gasification initiative. $\$ 14 \mathrm{M}$ has been appropriated in the current fiscal year, and a similar or larger amount is anticipated for FY 2001. Additional funds are available for basic research projects to support the success of the large-scale demonstrations. Among the areas being pursued are materials and corrosion issues, gas cleaning and the basic chemistry and physics of gasification.

After a decade of building a partnership to bring biomass and black liquor gasification to commercial reality, the players and the funding appear to be falling into place. However, the big steps of design and construction of the large-scale demonstration facilities remains.

\subsection{The Organization of This Report}

This report focuses on the potential application of the Battelle/FERCO residual gasification technology at the Weyerhaeuser mill in New Bern, North Carolina. It reports the results of studies carried out by Weyerhaeuser and Bechtel on the gasifier's cost and performance, 
taking into account process improvements over the design being implemented in Burlington. The report begins by discussing the results of a raw material availability study around Weyerhaeuser's facilities in Eastern North Carolina. These raw material availability studies included the possibility of utilizing nutrients from waste water for the purpose of growing an energy crop.

This section is followed by discussions of the gasifier island design and cost, and its integration into a pulp mill operating environment. The utilization of medium Btu gas from the Battelle/FERCO technology in a lime kiln was studied, and is included as well.

Weyerhaeuser worked with Stone \& Webster Engineering Corporation to look at the integration of the technology, specifically into the New Bern mill, but also more generically to enhance the understanding of how the technology can be used in any similar pulp mill application. A conventional technology alternative-existing power boiler relifing-will be presented as a point of comparison for the gasification technology.

This report will discuss the site characteristics and public policy considerations that will be necessary to provide sustainable economics to the first few projects. Conclusions of this work will be discussed and the detailed economic analysis carried out will be reported, giving emphasis to the major leverage points to achieve economic sustainability in future applications. From the beginning, it has been a strong belief that any project implemented must have economic sustainability.

Although the gasification project conceived at New Bern will not be built in the immediate future, it is hoped and believed that the results reported here will encourage and enhance the ability to find an appropriate location where the learnings and the process improvements that resulted from this project can find an early application. Biomass and black liquor gasification combined cycle technologies are among the very few defining technology needs for a sustainable future for this industry and must be developed so the industry has them available as commercial choices. 


\section{Section 2}

\section{Raw Material Availability}




\subsection{Raw Material Availability}

\subsection{Scope and Objectives}

Weyerhaeuser first looked at the economics and availability of wood and processing residuals for use in a gasification facility in the mid-nineties. The results of this study were described in a report to the Department of Energy in June, 1995, as part of the "New Bern Biomass to Energy Project Phase 1 Feasibility Study". The work reported here uses this prior study as a basis and updates the results.

The objectives of this work included developing a description of the fuel supply and the fuel costs for the biomass gasification options being proposed for New Bern. To address both existing and potential supplies, six strategies were developed to account for alternative sources, future costs, and environmental benefits. The strategies have been developed sufficiently to address real costs and benefits, in dollars, fuel supply, and sustainable forest management practices.

\subsection{Approach}

Availability and costs for volume from Weyerhaeuser forests and facilities were obtained from historical records and knowledgeable people in the company who have the responsibility for managing the forests and supplying the raw material for the mills. Information on plantation growth and economics was backed up by strategic planners and researchers who utilized computer runs on Weyerhaeuser's proprietary financial models. These models rely on extensive information collected and verified over many years on volume, growth and field operations. Estimates for items such as harvesting, collecting, transporting, site prepping, and planting were based on data from actual experience modified for the specific situation. Cost, volume, and growth estimates were generally modified towards optimism in an attempt to include a particular component such as biomass from plantations or from short rotation forestry. However, when it was apparent that inclusion of the component was not feasible, conservative estimates (those tending to reduce the quantity) were used to identify the quantity actually available for use in an energy facility.

Data for residual material potentially available from external sources was obtained primarily from resource bulletins published by the Southeastern Forest Experiment Station, United States Department of Agriculture (Resource Bulletins SE-111, SE-113, SE-120, \& SE-142). The Forest Experiment Station researchers and writers of the bulletins were especially helpful in interpreting the data in the bulletins and in making a special run to collate the mill residual data on a county-by-county basis. The quantity in each county was roughly proportioned on the basis of each county's area within mileage circles around New Bern to determine transportation cost and availability.

The forest residue quantity available from lands not owned by Weyerhaeuser was determined on a county-by-county basis. A recoverable residual biomass to merchantable growing stock ratio was determined on a full state basis since this was the lowest level that individual biomass component information was available (Resource Bulletin SE-142). This ratio was then applied to the merchantable growing stock for each county (from Resource Bulletins 
SE-111 \& SE-113) to determine the recoverable residual by county. In addition, several Weyerhaeuser people knowledgeable about raw materials assessed the quantity information on each component of forest biomass from the bulletin and estimated the amount of each component that would be recoverable and the portion of forests that would be accessible. This was compared with Weyerhaeuser experience and found to be conservatively low.

The data on residual material available from wood product facilities was examined in great detail and in several different ways. In the final analysis, the primary data source for the quantity generated and potentially available was again the Southeastern Forest Experiment Station bulletins. The bulletins contain information on mill residuals from mill surveys conducted every two years on all wood product facilities in the state. The amount available by county was proportioned on a mileage circle basis.

Since the data produced by the above approach indicated a significant volume $(160,000 \mathrm{BDT})$ of mill residuals generated within 40 miles, a more direct and detailed study was conducted. Weyerhaeuser Raw Material Managers directly contacted more than 80 mills (chip mills, pulp mills and sawmills) out to 160 miles to obtain the material type each mill was willing to market and the associated volume and price. The mileage to each mill was determined and the mileage related transportation cost was added to arrive at total costs.

\subsection{Findings}

There is sufficient biomass fuel available from the feedstock system surrounding New Bern to satisfy the feedstock needs of the gasification facility described in this report-236,200 bone dry tons (BDT) per year-at an average cost of $\$ 18$ per BDT. This biomass is made up of Weyerhaeuser mill residuals and woods residuals from the final harvest of natural stands and plantations and is all within a 60 mile transportation radius of New Bern (Figures 2-1 and $2-2$ ). A requirement of $390,000 \mathrm{BDT}$ raises the average cost to $\sim 23$ per BDT, increases the transportation distance to about 80 miles and adds woods residuals from non-Weyerhaeuser lands and more non-Weyerhaeuser mills. More volume would be available beyond 80 miles, but this was not pursued because of the scope of this project

The fuel for a New Bern facility could be sourced entirely from mill residuals. The $236,200 \mathrm{BDT}$ of fuel required represents $\sim 60 \%$ of the residual fuel that has been identified (Table 2-1). The least costly and most readily committed components are the residuals available from the New Bern and Greenville sawmill, pulp mill and chip mill. These amount to $146,000 \mathrm{BDT}$. 


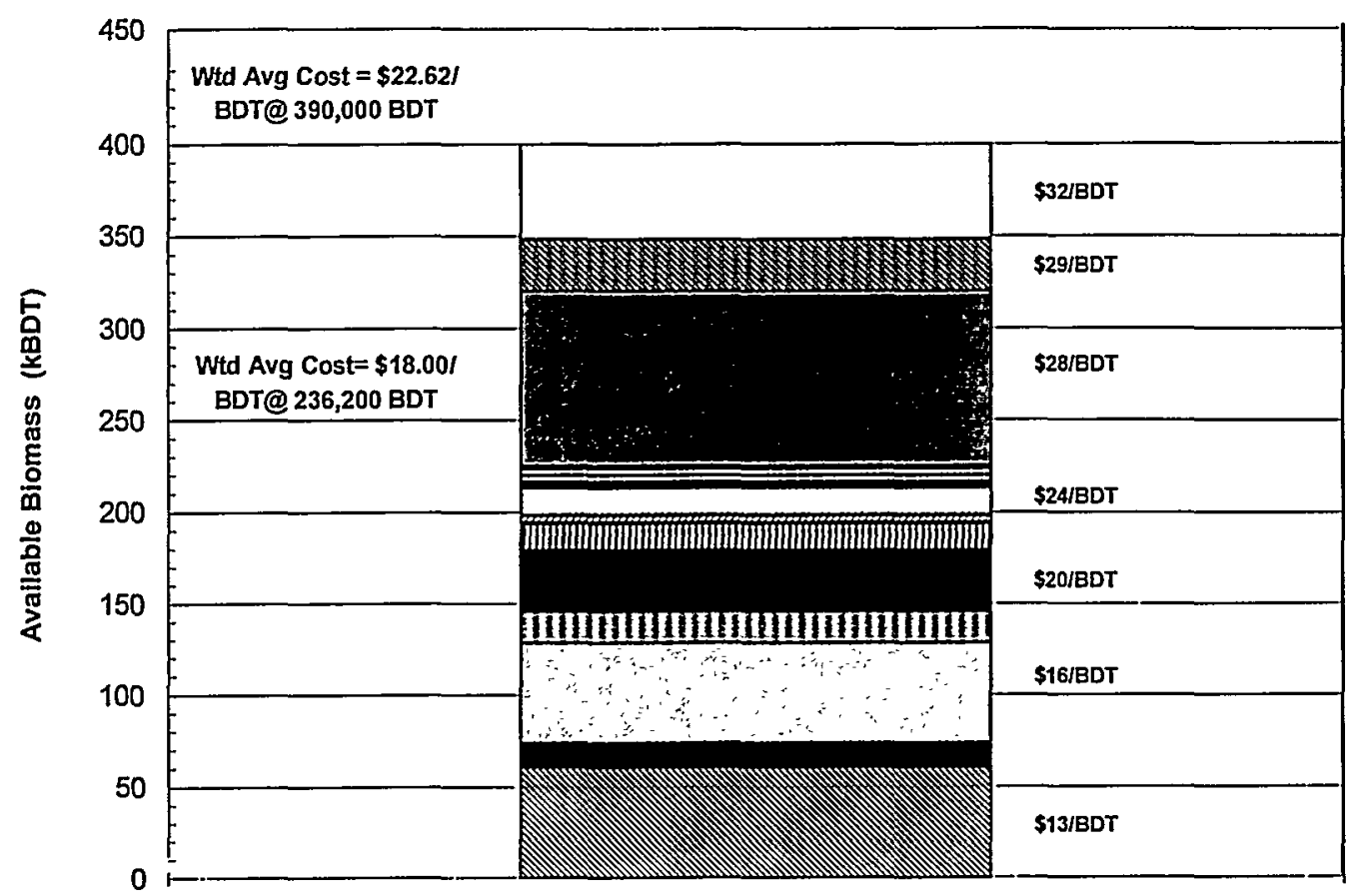

Figure 2-1: Residual Biomass Fuel Resources

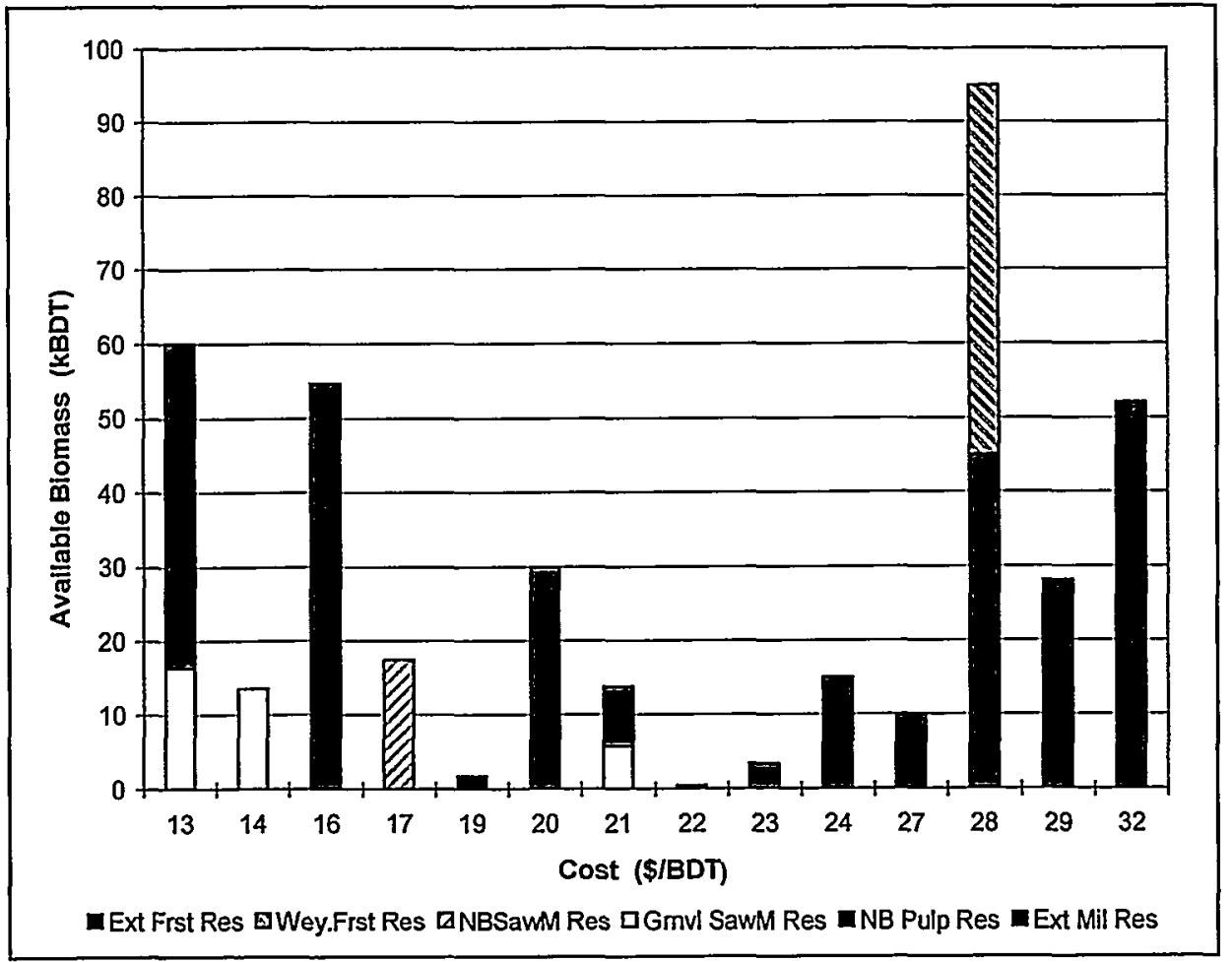

Figure 2-2: Total Biomass Fuel Resource 


\begin{tabular}{|c|c|c|c|c|c|c|c|c|}
\hline \multirow[b]{3}{*}{$\begin{array}{l}\text { Fuel Cost } \\
\text { (\$/BDT) }\end{array}$} & \multicolumn{4}{|c|}{ Weyerhaeuser Operations } & \multirow{2}{*}{\multicolumn{2}{|c|}{$\begin{array}{l}\text { Non-Weyerhaeuser } \\
\text { Operations }\end{array}$}} & \multirow[b]{3}{*}{$\begin{array}{c}\text { Total } \\
\text { Resldual } \\
\text { Fuel }\end{array}$} & \multirow[b]{3}{*}{$\begin{array}{c}\text { Accm. } \\
\text { Residual } \\
\text { Fuel }\end{array}$} \\
\hline & \multicolumn{4}{|c|}{ Mill Residuals } & & & & \\
\hline & $\begin{array}{c}\text { Final } \\
\text { Harvest } \\
\text { Residuals }\end{array}$ & $\begin{array}{l}\text { New Bern } \\
\text { Sawmill }\end{array}$ & $\begin{array}{l}\text { New Bern } \\
\text { Pulp MIII }\end{array}$ & $\begin{array}{l}\text { Greenville } \\
\text { Sawmill }\end{array}$ & $\begin{array}{c}\text { Final } \\
\text { Harvest } \\
\text { Residuals }\end{array}$ & $\begin{array}{c}\text { Mill } \\
\text { Reslduals }\end{array}$ & & \\
\hline 13 & & & 43.8 & 16.3 & & & 60 & 60 \\
\hline 14 & & & & 13.6 & & & 14 & 74 \\
\hline 16 & & & 54.7 & & & & 55 & 128 \\
\hline 17 & & 17.5 & & & & & 48 & 146 \\
\hline 19 & & & & & & 1.8 & 2 & 148 \\
\hline 20 & & & & & & 30.0 & 30 & 178 \\
\hline 21 & & & & 5.7 & & 8.1 & 14 & 192 \\
\hline 22 & & & & & & 0.4 & 0 & 192 \\
\hline 23 & & & & & & 3.4 & 3 & 195 \\
\hline 24 & & & & & & 15.0 & 15 & 210 \\
\hline 27 & & & & & & 10.0 & 10 & 220 \\
\hline 28 & 50.0 & & & & 45.0 & 3.4 & 98 & 319 \\
\hline 29 & & & & & & 24.6 & 25 & 343 \\
\hline 32 & & & & & & 52.0 & 52 & 395 \\
\hline $\begin{array}{l}\text { Source } \\
\text { Total }\end{array}$ & 50 & 18 & 99 & 36 . & 45 & 149 & 395 & . \\
\hline
\end{tabular}

Table 2-1: Total Biomass Fuel Resource (kBDT/year)

With the above information, six potential strategies were evaluated as possible approaches for supplying the needed biomass for the projects. These strategies are summarized below.

\subsection{Supply Strategies}

\subsubsection{Capture existing volumes of residuals available to Weyerhaeuser that are available at hog fuel (or lower) values}

\section{Weyerhaeuser Mill Residuals}

Weyerhaeuser processes predominantly pine into bleached market pulp and lumber at the New Bern, Greenville and Plymouth locations.

The New Bern pulp mill, New Bern sawmill and Greenville sawmill generate 146,000 BDT per year of bark, sawdust, screenings and hogged waste wood at values of $\$ 13$ to $\$ 17 / \mathrm{BDT}$ delivered to New Bern (Table 2-2). Greenville furnishes about $30,000 \mathrm{BDT}$ of residual material. At the present time, most of this material is sold to Craven Hydraco, a private electricity generating facility utilizing wood residuals, with some small portion going to the Plymouth wood waste boiler on a supplemental basis. 


\begin{tabular}{|c|c|c|c|}
\hline \multirow[b]{2}{*}{$\begin{array}{l}\text { Fuet Cost } \\
\text { (\$BDT) }\end{array}$} & \multicolumn{3}{|c|}{ Mill Residuals (kBDT) } \\
\hline & $\begin{array}{l}\text { New Bern } \\
\text { Sawmill }\end{array}$ & $\begin{array}{l}\text { New Bern } \\
\text { Pulp Mill }\end{array}$ & $\begin{array}{l}\text { Greenville } \\
\text { Sawmill }\end{array}$ \\
\hline 12.80 & & 43.8 & \\
\hline 13.10 & & & 16.3 \\
\hline 13.70 & & & 13.6 \\
\hline 15.60 & & 54.7 & \\
\hline 16.70 & 17.5 & & \\
\hline Total & 18 & 99 & 30 \\
\hline
\end{tabular}

Table 2-2: Weyerhaeuser Mill Residuals by Fuel Cost

The wood products facilities at New Bern and Greenville also generate about $10,000 \mathrm{BDT}$ of dry planer shavings. This material was not included as a source for fuel because of its very high value ( $\$ 40$ to $\$ 50 / \mathrm{BDT}$ ) as poultry bedding and furnish for engineered panels.

The obvious benefit of using the mill residuals as fuel is the large volume of lowvalue material already owned by Weyerhaeuser and-in the case of New Bernalready on site. The handling costs are the only incremental costs, and the existing value is what other people are willing to pay for fuel less transportation cost. Using this source of material for a new New Bern power plant provides a dedicated Weyerhaeuser supplier/consumer; a reliable flow of fuel; an opportunity to reduce current handling, marketing, and disposal costs; and the opportunity to add value to existing products.

\section{Non-Weyerhaeuser Plant Residuals}

Based on the mill surveys conducted by the Southeast Forest Experiment Station and an internal study conducted by Weyerhaeuser, there is over 160,000 BDT of mill residuals within a 40 mile radius of New Bern (Figure 2-3 and Figure 2-4).

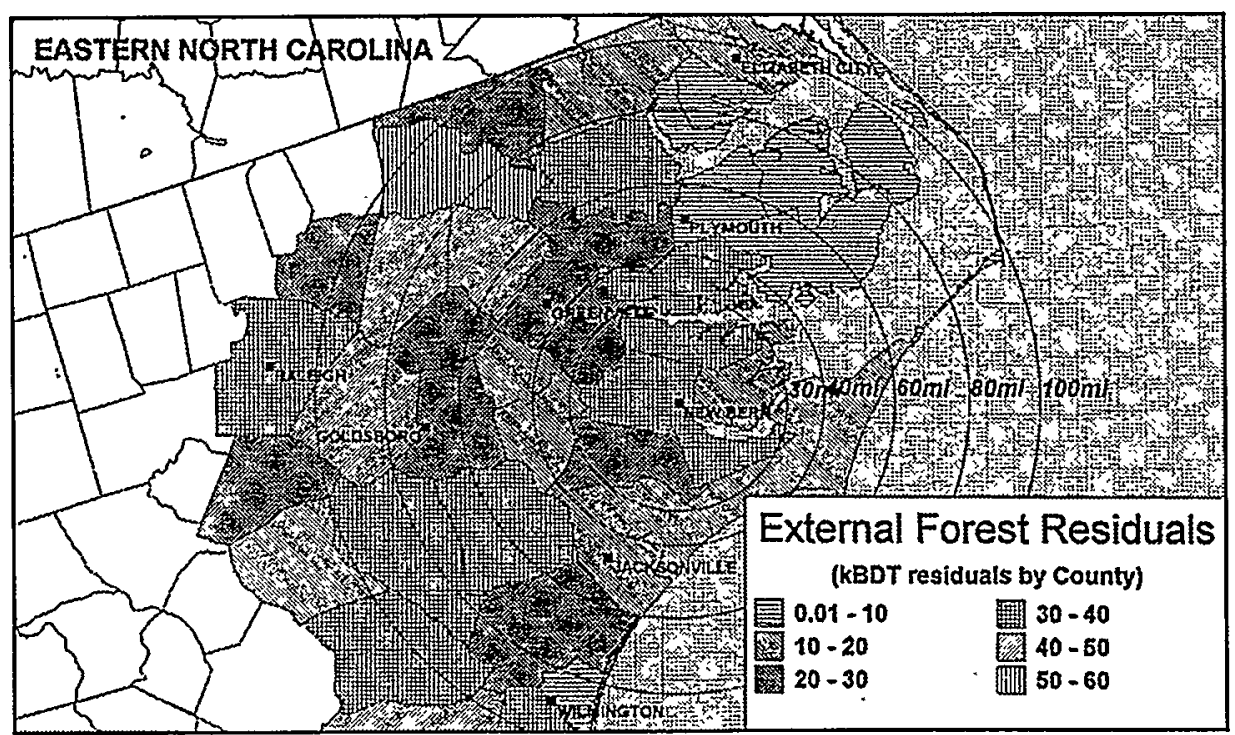

Figure 2-3: Map of External Forest Residuals 


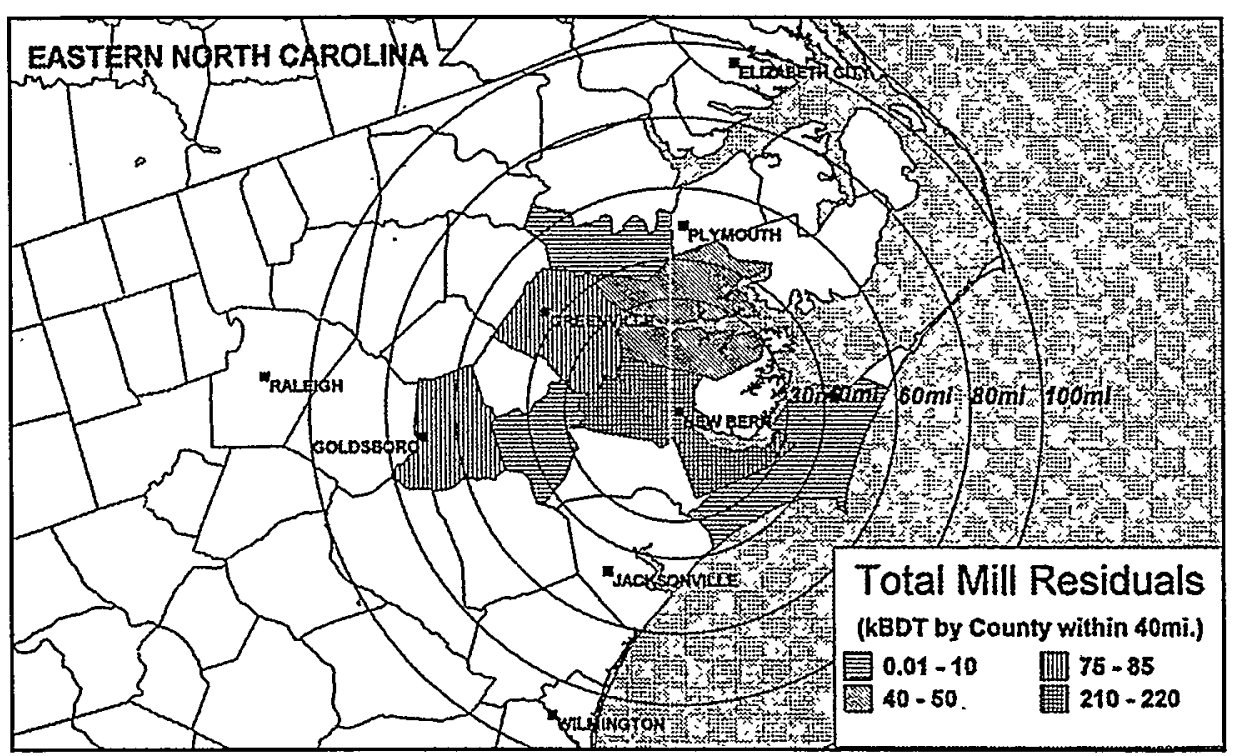

Figure 2-4: Map of Total Mill Residuals

The direct contact by the raw material managers to the 82 mills identified over 450,000 BDT (not including the planer shavings) of bark, sawdust, and hog fuel that the mills had available to market at a maximum price of $\$ 35 / \mathrm{BDT}$. The weighted average price for all 450,000 BDT would be $\$ 24 / \mathrm{BDT}$. A large portion of this was already being sold to others. Because of proximity to New Bern and the associated lower transportation costs, it is highly likely that a large portion of the 160,000 BDT of mill residuals within a 40 mile radius currently being utilized by others would be available to a New Bern facility. Since Weyerhaeuser mills and woods residuals are providing $193,000 \mathrm{BDT}$ of the 262,000 requirement, there should be little problem in obtaining the remaining 69,000 BDT from this source at their market prices.

Volumes from each mill range from $400 \mathrm{BDT}$ to $30,000 \mathrm{BDT}$ and costs from $\$ 19$ to \$27 (Table 2-3).

\begin{tabular}{|l|c|c|}
\hline Residual Product & Volume Produced (kBDT) & Price (\$/BDT) \\
\hline Hog Fuel & 1.8 & $\$ 19$ \\
Bark & 30.0 & $\$ 20$ \\
Bark & 2.4 & $\$ 21$ \\
Bark & 5.7 & $\$ 21$ \\
\hline Hog Fuel & 0.4 & $\$ 22$ \\
Hog Fuel & 3.4 & $\$ 23$ \\
Screenings & 15.0 & $\$ 24$ \\
Sawdust & 2.5 & $\$ 27$ \\
\hline Sawdust & 7.5 & $\$ 27$ \\
Bark & 3.4 & $\$ 29$ \\
Mix & 24.6 & $\$ 29$ \\
Mix & 52.0 & $\$ 32$ \\
\hline Totar & 149 & \\
\hline
\end{tabular}

Table 2-3: Non-Weyerhaeuser Mill Residuals (\$/BDT) 
Continued efficiency improvements in wood product plants and increases in residual uses could somewhat reduce the amount available from wood product mill facilities in the 2000 and beyond time frame. However, having to take more volume from the next highest cost mill residual increment would only increase the average cost by $\$ 1$ to $\$ 2 / B D T$.

\section{Poultry House Waste}

Dry planer shavings from Weyerhaeuser and other sawmills are being purchased at a high value ( $\$ 30$ to $\$ 34 / \mathrm{BDT}$ ) and utilized as bedding material in the burgeoning North Carolina poultry business. After use, the material is reclaimed from the poultry houses and some of it is spread on farm fields as mulch and fertilizer. One of the larger users, Goldsboro Milling, uses approximately 90,000 tons of shavings annually to which the poultry adds about 25,000 tons. Today, there is a cost to Goldsboro Milling to reclaim, load, haul and spread the material in the fields as well as a problem with winter time disposals when the fields are too wet to spread. Goldsboro is very interested in alternative disposals, and it was assumed that this material would be available for the cost of transportation or $\$ 8$ to $\$ 12 / B D T$. Since it was not known if the fuel facility could handle this material, it was not included in the following summaries.

\section{Summary}

Mill residuals from Weyerhaeuser mills are an obvious first choice for fuel as they are readily available, can be committed to internal use and for the most part are the lowest cost. Residuals from external mills are the next obvious choice because of their attractive prices and large quantity available on the market. The use of poultry house residuals could reduce the average cost of fuel.

\subsubsection{Incorporate mill residuals that currently are going to landfill or lagoon disposal sites at a net cost and long-term liability to the Company.}

New Bern Pulp currently sends sludge (23,850 wet tons) to an old landfill as $10-15 \%$ solids at about a $\$ 4.00 / \mathrm{T}$ handling cost (est.). New landfill space would have a much higher cost. Probability of permitting additional landfill construction beyond the current space is difficult and would require significant capital.

The landfill and the treatment lagoons at New Bern have many tons of material that could be recovered as a fuel source. The lagoons may have to be dredged in the near future with expensive disposal alternatives. Combustion under controlled temperature is a potential remediation process. Plymouth has a system in place to dry dredged sludge for burning, but does not have the capacity to dry and burn all their lagoon sludge if further clean up is required. A system designed with the temperature requirements of sludge burning at New Bern could be a desirable home for this material. The mill residuals included in this discussion are generally not net contributors to an energy balance due to their high moisture levels ( $85 \%$ to $90 \%$ moisture content). However, the use by the energy facility would have a significant benefit to the mill site in the form of reduced operating cost for disposal. There may be qualities that discourage their use as a fuel source. However, these residuals are part of the current manufacturing process and do have costs and limited options for 
disposal. Use in an energy system would capture some benefit from materials that are currently direct costs. Landfill or lagoon storage have been low cost options, but creation of new space will continue to increase in cost with significant regulatory barriers that may prevent long term continuation without changes and significant costs. Thermal conversion in a gasifier or combustion system may be an attractive alternative.

\section{Summary}

Requires suitable drying technology, regulatory driven, some risk, and not a significant Btu source.

\subsubsection{Capture existing and/or potential woods residual chips from final harvest and plantation thinning, that are available at hog fuel prices plus transportation.}

\section{Non-Weyerhaeuser Forest Residuals}

Every four to six years the Southeastern Forest Experiment Station of the U.S. Forest Service conducts a survey of the North Carolina standing forest inventory and operational logging sites. Based on the 1996 analysis of the 1989 survey (no later survey was available at the time of this study), $8 \%$ of the merchantable growing stock (6\% softwood, $10 \%$ hardwood) in harvested areas is left in the woods as logging residue. In addition, unmerchantable material, composed primarily of small stems1 " to 5" dbh (diameter at breast height) - and tops and limbs, but with a portion of salvageable dead trees, rough trees and partially rotten trees, is not currently recovered. The total unmerchantable material is an increment about $25 \%$ greater than the merchantable growing stock for softwood and about $55 \%$ greater than the merchantable growing stock for hardwood.

After several knowledgeable people assessed each unmerchantable component for recoverability, it was determined that approximately $40 \%$ of the unmerchantable pine and $35 \%$ of the unmerchantable hardwood would be recoverable from those stands selected for residual harvest. It was also assumed that residual recovery would not be attempted on $50 \%$ of the stands due to small stand size, inaccessibility, operability constraints, low volume per acre, and a future shift from natural stands to more plantations for Weyerhaeuser and other large forest products companies. The increment to the merchantable growing stock removal amounts to $16 \%$ (about $7 \mathrm{BDT} / \mathrm{acre}$ ) for softwood and $31 \%$ (about $13 \mathrm{BDT} / \mathrm{acre}$ ) for hardwood. Residual availability was determined for each county and then each county was proportioned on the basis of map area and portions assigned to specific mileage zones around New Bern. Residual availability and costs were determined for mileage zones from 40 to 100 miles in 20 mile increments (Table 2-4). 


\begin{tabular}{|l|c|c|c|c|c|}
\hline Distance from New Bern (miles) & 30 & 40 & 60 & 80 & 100 \\
\hline Material Available (kBDT) & 92 & 58 & 122 & 157 & 209 \\
\hline Recovery Cost (\$/BDT) & $\$ 20$ & $\$ 20$ & $\$ 20$ & $\$ 20$ & $\$ 20$ \\
\hline Transportation Cost (\$/BDT) & $\$ 7$ & $\$ 8$ & $\$ 11$ & $\$ 14$ & $\$ 17$ \\
\hline Total Cost (\$/BDT) & $\$ 27$ & $\$ 28$ & $\$ 31$ & $\$ 34$ & $\$ 37$ \\
\hline
\end{tabular}

Table 2-4: Non-Weyerhaeuser Forest Residuals by Distance from New Bern

Recovery of forest logging residuals at the time of final harvest for roundwood is already a significant and reliable source of biomass fuel for the Weyerhaeuser wood residue boilers in Plymouth. Its contribution has ranged from $10 \%$ to $35 \%$ of the Plymouth wood fuel source over the last eight years. Although higher in cost than the mill residual increment by up to $\$ 10 / \mathrm{BDT}$ within the same transportation zones, it is available in significant quantities within a 100 mile hauling distance of New Bern.

For more than 8 years, Weyerhaeuser has experienced a residual recovery of 10 to $15 \mathrm{BDT} / \mathrm{acre}$ on natural pine stands. Logging contractors have developed efficient systems for residual recovery over the more than 8 years of producing fuel for Weyerhaeuser. They are now realizing incremental harvest costs which range from $\$ 18$ to $\$ 22 / \mathrm{BDT}$ with transportation and handling costs an additional $\$ 8$ to $\$ 15 / \mathrm{BDT}$ with hauling distances up to 70 miles.

With the significant volume available as shown above and based on Weyerhaeuser experience, there should be no problem producing 100,000 BDT per year. Four chipping contractors would be able to produce 100,000 to 120,000 BDT per year with most coming within 50 miles of New Bern at a delivered cost of \$28.30/BDT.

The lower costs of regeneration behind harvest operations utilizing a woods chipper to remove more biomass provides a competitive advantage for purchase of stumpage from some small private landowners. While this type of advantage may be difficult to assign a value to, as competition for timber increases it may be the difference in being competitive for this timber stumpage.

\section{Weyerhaeuser Natural Stands and Plantation Final Harvest}

Merchantable volume from final harvest of natural stands is decreasing as the natural stands are depleted and residual volume per acre also reduces from the current $16 \mathrm{BDT}$ per acre to $12 \mathrm{BDT}$ per acre by 2008 . Merchantable volume from final harvest of plantations will continue to increase until about the year 2004, and then level off at that amount into the foreseeable future. Based on projected quantities of limbs and tops and the residual recovery results from early plantation harvests, there appears to be 3 to $5 \mathrm{BDT} / \mathrm{acre}$ of residual biomass available for fuel. This is composed of non-merchantable stems, hardwood in-growth, pine tops and large limbs, landing scraps, long butts and lily pads.

Because of more intensive management, future plantations will have less nonmerchantable material and hardwood in-growth resulting in a decrease of residuals to 2 to $4 \mathrm{BDT} /$ acre. It was estimated that at least $50,000 \mathrm{BDT} /$ year could be recovered 
from natural and plantation stands (Table 2-5). With an identified need and improved values, this could be increased slightly through the use of harvesting heads which could cut off the stem at or slightly below ground level. Residual harvest costs will be about the same as for the non-Weyerhaeuser forest residuals at $\$ 28.30 / \mathrm{BDT}$.

\begin{tabular}{|c|c|c|c|}
\hline Harvest Year & Plantation Residuals & Natural Stand Residuals & Total Residuals \\
\hline 2000 & 46 & 82 & 129 \\
\hline 2001 & 70 & 61 & 131 \\
\hline 2002 & 59 & 41 & 100 \\
\hline 2003 & 56 & 41 & 97 \\
\hline 2004 & 76 & 10 & 86 \\
\hline 2005 & 80 & 3 & 83 \\
\hline 2006 & 76 & 17 & 93 \\
\hline 2007 & 83 & 2 & 86 \\
\hline 2008 & 93 & 7 & 100 \\
\hline 2009 & 83 & 9 & 92 \\
\hline 2010 & 101 & 7 & 108 \\
\hline
\end{tabular}

Table 2-5: Weyerhaeuser Forest Residuals - kBDT

\section{First Thinning}

Market conditions will dictate the stocking level of future plantations in North Carolina. Depending on the value of chips and fuel at first thinning in relation to the value of diameter at final harvest, there may be some options to increase chip and/or fuel harvest removals in the first thin. However, higher expected future demand for chips from already planted plantations is expected to shift the existing first thinning activity from fuel production to pulp and paper chip production for export and domestic sales.

Although the total volume for fuel from this source will decrease, if these operations utilize woods chipping with flail debarking about 5 tons/acre of flailed bark, limbs and tops can be recovered for fuel as a by-product of the chips at a recovery (grind and load) cost of approximately $\$ 25 / \mathrm{BDT}$ and average transportation cost of $\$ 8$ to $\$ 12 / B D T$. This could provide about $20,000 \mathrm{BDT}$ of residual fuel annually during the 1998 to 2006 time frame (Table 2-6) but is above the cost of the other alternatives.

First thinning on already planted more heavily stocked plantations is expected to be completed by 2006 when the wider spacing and fewer trees of the new regime will start to be thinned and overall removal volume and residual volume will be significantly reduced. The new planting regime would only yield about 1 to 2 tons/acre of residuals from thinning; and because of low volume (requires coverage of up to 24 acres for each truckload), could only be applied to the highest volume stands (assumed to be applicable to $40 \%$ of available stands), which would make it costly to recover. This would only provide 5,000 to 8,000 BDT per year. 


\begin{tabular}{|c|c|c|}
\hline \multirow{2}{*}{ Harvest Year } & \multicolumn{2}{|c|}{ Blomass (kBDT) } \\
\cline { 2 - 3 } 2000 & $20 \%$ Available Flail \& Chip & Produced on 60\% of Stds \\
2001 & 30 & 18 \\
2002 & 29 & 17 \\
2003 & 28 & 17 \\
2004 & 37 & 22 \\
2005 & 26 & 16 \\
2006 & 36 & 21 \\
& 31 & 19 \\
2007 & $10 \%$ Avaliable Flail \& Chip & Produced on 40\% of Stos \\
2008 & 16 & 6 \\
\hline
\end{tabular}

Table 2-6: First Thinning Residuals

North Carolina operations are also considering an alternative to the woods chipping approach for first thinning in both time frames, which removes the thinning material in roundwood log form from the forest and processes the stems at a chip plant. This would still recover the bark at the chip plant; but since the chipping or grinding process would need to be brought to the woods specifically for the small increment of fuel from the limbs and tops (less than 1 ton/acre or more than 24 acres required per truckload), the costs would probably be prohibitive for either of the above plantation time frames.

\section{Second Thinning Residuals}

If second thinning is conducted in the future, cut-to-length harvesters will be utilized for second thinning. This process removes the limbs and tops and leaves them at the stump while recovering all of the stem to the terminal bud. Recovering these limbs and tops would be more difficult than first thinning or final harvest residuals recovery because, in addition to being a very low volume (less than $1 \mathrm{BDT} / \mathrm{acre}$ ), the harvest costs would be considerably higher since they would have to be independently collected at the stump and transported to roadside. This would make the costs considerably higher $(\$ 5-\$ 7 / \mathrm{BDT}$ ) than any of the alternative biomass fuel options and would also require incremental fertilization to offset the limbs and tops nutrient contribution.

\section{Site Preparation Residuals}

The initial V-shear operation produces a roll of biomass on each side of the blade, even with a fairly clean logging job. This material consists of stump lily pads, nonmerchantable stems, understory, and soil litter. After the V-shear pass for slash disposal behind final harvest, a flail-type chipper on a Hydro-ax with a collection system (silage chopper concept), could be used to collect the residual biomass. However, there is a value in this material to the long-term organic matter levels on mineral soils. In addition, there is a question about how much of this shearing will be done long term if the EPA/Corps continues their present direction. Given the regulatory risk, soil organic matter impact, harvesting cost, and other options, this should not rank very high on the list of biomass options. 


\section{Summary}

Though not the lowest cost, the woods residual component from final harvest is a large source of biomass fuel. Based on the conservative assumptions above, there is about 209,000 BDT of non-Weyerhaeuser forest residuals available within 100 miles of New Bern. Weyerhaeuser forest residuals account for about 50,000 BDT more. Residual volumes from thinning are very low and have a high cost. Because of the low volume of material available from thinning and the mechanical systems being utilized, the costs of recovering residuals are not currently competitive.

\subsection{4: Grow biomass by maximizing pine volumes per acre without giving up solid wood values, and trying to hold costs to hog fuel values plus transportation.}

\section{Pine Inter-row Planting}

The most cost effective (most tons of biomass produced) approach to increase available biomass would be to plant more trees, make more frequent thinning entries, leave more trees at each entry, lengthen the rotation and forego some diameter growth. An option to achieve this is to plant an additional row of pine between the rows of the existing current prescription and then remove all of the trees in the extra row plus some in the normal rows to reach the desired 200 trees per acre after thinning. If the final harvest values are assumed to be unaffected by this additional row-even though current forest growth and financial models indicate that the smaller trees would be worth less-then the incremental site preparation cost must be offset by the value of the additional material removed in the thinning. In order to earn $8 \%$ real after tax on the additional site preparation and planting investment, the thinning material must have a value of \$90/BDT if thinned at 14 years and \$120/BDT if thinned at 10 years (Table 2-7, Option 1).

\begin{tabular}{|c|c|c|c|c|c|}
\hline Thin Age & 10 & 11 & 12 & 13 & 14 \\
\hline $\begin{array}{c}\text { Option 1: All merchantable and residuals to fuel } \\
\text { Required Fuel Value for viable economics }\end{array}$ & $\$ 120$ & $\$ 100$ & $\$ 95$ & $\$ 90$ & $\$ 90$ \\
\hline $\begin{array}{c}\text { Option 2: Assumed 10\% higher final stand value; all } \\
\text { thinning material to fuel } \\
\text { Required Fuel Value for viable economics }\end{array}$ & & $\$ 50$ & $\$ 45$ & $\$ 45$ & $\$ 45$ \\
\hline $\begin{array}{c}\text { Option 3: Option 2 with 80\% of bole from thinning to } \\
\text { chips; 20\% of bole to fuel } \\
\text { Required Fuel Value for viable economics }\end{array}$ & $\$ 85$ & $\$ 50$ & $\$ 40$ & $\$ 35$ & $\$ 35$ \\
\hline
\end{tabular}

Table 2-7: Inter-row Planting - 450 to 800 trees/acre

There is a possibility that the loss of value from having a smaller log (due to the heavier initial stocking) might be offset by a benefit from the smaller low value juvenile $\log$ core and smaller limbs/knots. If a higher final harvest stand value of about $10 \%$ is assumed, then-since the thinning provides an offsetting benefit-the total required return for thinning and the resulting fuel value can be reduced by $50 \%$ (Table 2-7, Option 2). This requires a high fuel value of $\$ 45$ to $\$ 60 / B D T$. However, if $80 \%$ of the material is allocated to the higher value of chips (with a chip price of $\$ 50 / \mathrm{BDT}$ ), the fuel would only need a value of $\$ 35$ to $\$ 40 / \mathrm{BDT}$ for ages 14 to 12 respectively. 
The incremental costs of almost doubling the site preparation and planting costs for the current values of fuel-or even optimistically high future values - do not appear to be warranted for the harvest of fuel alone. However, if chip prices for pulp and paper increase significantly (above \$50/BDT) and if an increase in final harvest values can be validated, a higher planting level with subsequent thinning for chips and fuel could be justified.

Early fertilization on responsive stands has been shown to provide the option to increase first thinnings removal at age 12 by 3-4 BDT and still leave larger diameters on crop trees. While this approach does not minimize DOS (unpruned, low value core), the combination of values from a single lift prune, chip harvest, and growing to a larger final diameter may be a net benefit.

\section{Summary}

Biologically feasible; low volumes, high plantation establishment and carrying costs.

\subsubsection{Grow maximum pine/hardwood biomass per acre trying to hold costs to hog fuel plus transportation}

\section{Hardwood Sprouting Between Rows}

The next increment of volume would come from a strategy that intentionally grew biomass fuel as opposed to using residuals from other processes. A low-investment approach within the existing solid-wood strategy could use the current bed spacing to advantage. Most of Weyerhaeuser's sites have an understory component of Red Maple, Pepperbush, Sweetgum, Bay, etc. that is not killed with the V-streaking. This is heavier in natural stands, but plantations can have a significant component. With early thinning, more thinning entries, and wider row spacing, the understory is heavier. North Carolina has not used brush control like the rest of the South. However, brush control between rows might be needed to reduce competition with the pine; but would only be done if the competition level was severe. Energy harvest could replace a brush control on these sites. One of the options for this brush control would be a mechanical chopping or mowing, which would replace part of the harvesting cost of an energy operation.

Seeding between the rows is an option, but most of the native species would have a prohibitive seed cost compared to planting. The plantation would then be fertilized, bedded and planted with weed control directly on the top of the bed. The materials between rows could be re-harvested just before second thinning or final harvest, or when volume justified with a yet to be developed silage chopper concept. This regrowth material would be Sweetgum, Red Maple, Pepperbush, and Switchcane.

The harvest costs associated with this biomass harvest would be higher than standard round wood harvest or woods chipping costs. There is an additional cost associated with this strategy that is less apparent. The understory material has a higher concentration of nutrients than pine bark and stem wood. The nutrient concentration increases with increases in the percentage of leaves and non-woody material. Most of eastern North Carolina has soils that are nutrient limited, with much of the available nutrient supply tied up in vegetation. Natural additions to the nutrient pool are limited and would not compensate for removals associated with intensive biomass 
harvesting of the understory. Thus, nutrient replacement is essential to insure longterm sustainability of this type of system.

An option for this nutrient replacement is to spread the residual ash from the biomass boiler back across the harvested acres. Research done internally by Weyerhaeuser has shown the costs and values associated with this process. Estimated application costs are less than costs of new landfill space, so replacement of nutrient removals from biomass harvesting could be limited to nitrogen and phosphorus replacement. There is always the potential for new harvest technologies that would separate leaves and other small pieces from the larger pieces and return these to the forest floor with a resulting reduction in nitrogen and phosphorus replacement cost.

There are values associated with soil organic matter related to water movement, soil structure, root penetration, slow release of nutrients, maintenance of microbial populations, and nutrient retention in the upper soil profile that are extremely difficult to quantify. A conceptual example is the comparison of an old field plantation with a stand on a woods site. The woods site may or may not exhibit the greater productivity of pine, but the greater ecosystem diversity and buffering capacity results in a greater total productivity. The old field site is more comparable to row crop agriculture in relation to the requirement of nutrient additions in excess of removals to maintain long-term productivity potential.

Another issue in this type of system is the amount of traffic over the soil with heavy harvesting equipment. Rutting and compaction seriously impact the surface rooting volume of most soils and subsequent tree growth. Amelioration during site preparation can alleviate some impacts.

\section{Hardwood Inter-Row Planting}

The next increment of volume (and cost) would be to plant Sweetgum or Red Maple in a row between the rows of pines. A nitrogen-fixing tree species that was not very competitive with the pine crop trees would be desirable for this use. However, there is not a native species available. Wax Myrtle is an aborescent shrub that has some potential. Black Locust has been used in mine reclamation for this purpose, but is not native or particularly adapted to eastern North Carolina. This row would be chipped at first thinning entry and resprouting encouraged. The sprouts could be harvested whenever volume justified reentry. The incremental costs associated with this approach are primarily the planting stock and planting labor.

\section{Summary}

Biologically feasible; high risk, low volumes, high plantation establishment and carrying costs and high harvest costs with current harvest technology.

\subsubsection{Dedicated Short Rotation Plantation}

Weyerhaeuser foresters believe that for the Eastern North Carolina region the lowest cost fast growth tree crop to grow is a Loblolly Pine plantation. With the addition of sludge as discussed in the next section, it was assumed that the site index could be increased to an 85 . For a harvest age of 10 years, it appears that 800 trees per acre initial planting is a good balance between site preparation, planting, and harvesting costs and maximum biomass growth. As above with Strategy 2.4 .4 , it is assumed that 
the harvested material must have a value high enough to earn $8 \%$ real after tax on the site preparation and planting investment. Based on projections of growth and volume and expected planting, site preparation and harvesting cost, fuel value would have to reach about $\$ 50 / \mathrm{BDT}$ in order to achieve the required return (Table 2-8, Option 1, Alternative A). If site preparation and planting costs could be reduced by about $20 \%$, then fuel values would only have to reach about \$45/BDT (Table 2-8, Option 1, Alternative B). If they could be dramatically reduced by $75 \%$, fuel values would only have to be \$30/BDT (Table 2-8, Option 1, Alternative C).

\begin{tabular}{|l|c|c|c|}
\hline \multicolumn{1}{c|}{ Alternative } & A & B & C \\
\hline Site Index & 85 & 85 & 85 \\
Initial Trees (trees/acre) & 800 & 800 & 800 \\
Final Harvest Age & 10 & 10 & 10 \\
Site Preparation \& Planting Cost & Normal & $80 \%$ & $25 \%$ \\
\hline $\begin{array}{l}\text { Option 1: All Merchantable and Residuals to Fuel } \\
\quad \text { Total Required Return (\$/BDT) }\end{array}$ & & & \\
\hline $\begin{array}{l}\text { Option 2: Merchantable to Chips and Residuals to Fuel } \\
\text { Fuel price to return 8\% on site preparation (\$/BDT) }\end{array}$ & & & \\
\hline
\end{tabular}

Table 2-8: Short Rotation Pine Plantation

Though it would reduce the amount of biomass for fuel, a more feasible though still optimistic alternative would be to harvest for fuel and for pulp and chips. Fuel costs would only have to reach $\$ 30 /$ acre with a $20 \%$ reduction in site preparation and planting costs (Table 2-8, Option 2, Alternative B).

The above scenarios all assume an optimistically low harvest and transport cost and a relatively high chip price for a very high site with no incremental cost for the application of sludge to achieve the high productivity site. 


\section{Section 3}

\section{Energy Crop Possibilities}




\subsection{Energy Crop Possibilities}

\subsection{Background}

Economic constraints and value of alternative products have limited wood production for energy purposes in intensive plantation regimes. A potential opportunity was identified which included the growing of high-value saw timber with municipal wastewater in intensively managed plantations and to produce significant amounts of wood for energy in the process.

The Neuse River has a documented history of nutrient related water quality problems that are linked to effluent discharges from various sources. Municipal treatment plants are recognized as primary point source contributions. Recent limits restricting nitrogen loading in sewer plant permits makes alternatives to point source discharge more attractive. Published research shows that land application of treated municipal and industrial wastewater on forestland has been utilized successfully at various locations in the South for up to 30 years. Land application is one of the most cost-effective and environmentally-sound processes for the recycling of wastewater. Limited availability of well-drained soils and rising land cost, coupled with increased growth and the need for greater wastewater treatment capability, have caused a decline in land application.

Eastern North Carolina is dominated by hydric soils with seasonally high water tables. Under current State guidelines, these soils are not generally permitted for land application. Weyerhaeuser and other forest landowners have established loblolly pine plantations of upland hydric soils throughout the coastal plain using water management and drainage systems to reduce the periods of high water tables. In the Neuse Basin, Weyerhaeuser owns over 200,000 acres with a total of about 570,000 acres in eastern North Carolina. Including private landowners and other industry, about $60 \%$ of North Carolina's coastal plain is covered with managed forests. Weyerhaeuser Company and many private landowners are interested in production of high-value sawtimber, but are limited by markets for early thinnings. Energy wood market opportunities coupled with the nutrient values of wastewater would support an intensive plantation management regime that would meet these objectives.

In managed plantations, the extensive root system and accumulation of organic matter promotes and enhances infiltration, percolation, and denitrification of wastewater in the soil. Loblolly pine provides rainfall interception, evaporation, and transpiration during the entire year. All of these factors significantly reduce the surface water runoff potential. Nutrient uptake by fine roots in the surface soil is rapid under most conditions. Denitrification, a primary process in nitrogen reduction, can also occur in these wet forest soils. Soil microorganisms change nitrate-nitrogen in shallow groundwater to gaseous nitrogen. (Amatya, D., Gilliam, J.W., Skaggs, R.W., and Blanton, C.D.; 1996)

The North Carolina State Forest Nutrition Cooperative has documented loblolly pine growth increases of $30 \%$ with 200 pounds of nitrogen and 25 pounds of phosphorus fertilizer per acre. Recent efforts are focused on nitrogen dosage/frequency studies in younger stands. Results from the SETRES site in Scotland County have shown the substantial increases in growth associated with frequent, complete fertilization and irrigation on a droughty site. 
Treated wastewater nutrient analyses are very low, with application rates usually limited by hydraulic loading rather than nutrient levels. However, cumulative applications should produce growth response. "Managed pine forests in the coastal plain grow on nutrient deficient soils and, thus, are effective nutrient sinks." (Gilliam, J.W.; 1995).

Research efforts over the last 30 years have provided excellent data on loblolly pine water and nutrient use, and this demonstration project considers several specific questions. The impact of land application of water during the peak growing season that typically has a moisture deficit is evaluated. The project was designed to quantify the water and nutrient balance for the selected site, and tree growth and nutrient uptake provided permitting and management guidance. Data was used to validate the utility of DRAINMOD (Skaggs, 1978) and NUTREM (NCSFNC, 1998) as models to predict water and nutrient balances, respectively, on potential land application sites in the Neuse River basin and eastern North Carolina.

\subsection{Objectives}

1) Determine the feasibility of seasonal fertigation of mid-rotation loblolly pine on hydric soils in eastern North Carolina as a technology to increase production of wood for energy as a co-product of a sawtimber rotation.

2) Quantify the nutrient and water balances with different amounts of water to assess the potential for nutrient movement off the site.

3) Evaluate the utility of the water balance model DRAINMOD and the nutrient model NUTREM for prediction of water and nutrient balances.

4) Demonstrate the potential for low-cost, mobile systems.

\subsection{Approach}

The demonstration project used simulated wastewater, based on the five-year average analysis for the City of New Bern's effluent. A specially formulated liquid fertilizer was injected into irrigation water as it was applied. By mixing the nutrient concentrations to the same analysis in every application, the variation in nutrient contents often seen in long-term wastewater application studies was controlled. For an operational system, dischargers would haul or pipe the treated effluent to permitted forestlands. The project also demonstrated multiple application technologies suitable for non-dedicated forest sites. The mobile systems (i.e., irrigation hose or traveler system) are lower cost and more adaptable to normal forestry activities than traditional fixed riser systems.

\subsubsection{Field Study}

The site is located on a Company-owned 12-year-old loblolly pine plantation. It represents a large percentage of Company land ownership on drained hydric soilspecifically, a Pantego fine sandy loam. The property lies within the Neuse River basin in Craven County off NC 1005 near the Craven County Landfill at Tuscarora. 


\subsubsection{Treatments}

A minimum application period was proposed from May-October ( 6 months) based on the growing season of loblolly pine with peak leaf area in August. The June-October hurricane season of 1995 and 1996 produced a higher than average rainfall resulting in a worst case scenario.

In order to answer both how much and how often wastewater can be applied, the treatments consisted of:

- High Volume (4 in. every other month from May to Oct. $=12$ in./year)

- High Frequency ( 2 in. every month from May to Oct. $=12$ in./year)

- Constant Wetting (maintains water table at 12 in. below soil surface)

- Control (average rainfall last 5 years is May-2.72 in., June-3.66 in., July5.88 in., August-6.64 in., September-6.80 in., and October-4.49 in.)

\subsubsection{Application Systems}

A traditional "fixed" spray irrigation system would be cost-prohibitive for the frequency and duration of application being considered. Therefore, low-cost and highly mobile delivery systems were utilized. These included:

1) Modified surface application, in which the water is distributed through surface pipes. Advantages of this system include limited disturbance to the soil and plant roots and decreased human exposure due to no aerosol production.

2) Traditional reel system, used in agricultural land application. The water pressure was decreased dramatically so the tree bark would not be injured. The "gun" trolley is slowly retracted down the third (cut) row while supplying water to the four rows on either side.

The two delivery systems mentioned above were combined with the four treatments for a total of eight regimes in order to determine the best silvicultural practice, in terms of both economic and environmental standards.

\subsubsection{Plot Layout}

Schematics of the plot layouts are seen in Figures 3-1 and 3-2. Operational third row select thinning with an average of 150 residual trees/acre was the uniform pretreatment. The first delivery system, shown in Figure 3-1, utilizes irrigation hoses in the middle three cut rows to supply water to the trees on each side. The water pressure and hose construction were calculated such that the water would be as evenly distributed as possible.

Figure 3-2 shows the second delivery system using the third (cut) row as the distribution path. In an agricultural setting, the gun can shoot water in a 120' radius. This approach was modified for forest application by decreasing the pressure and using a diffuse nozzle, resulting in water flows of approximately $40^{\prime}$ in all directions. This wets four rows of trees on each side of the reel device. 

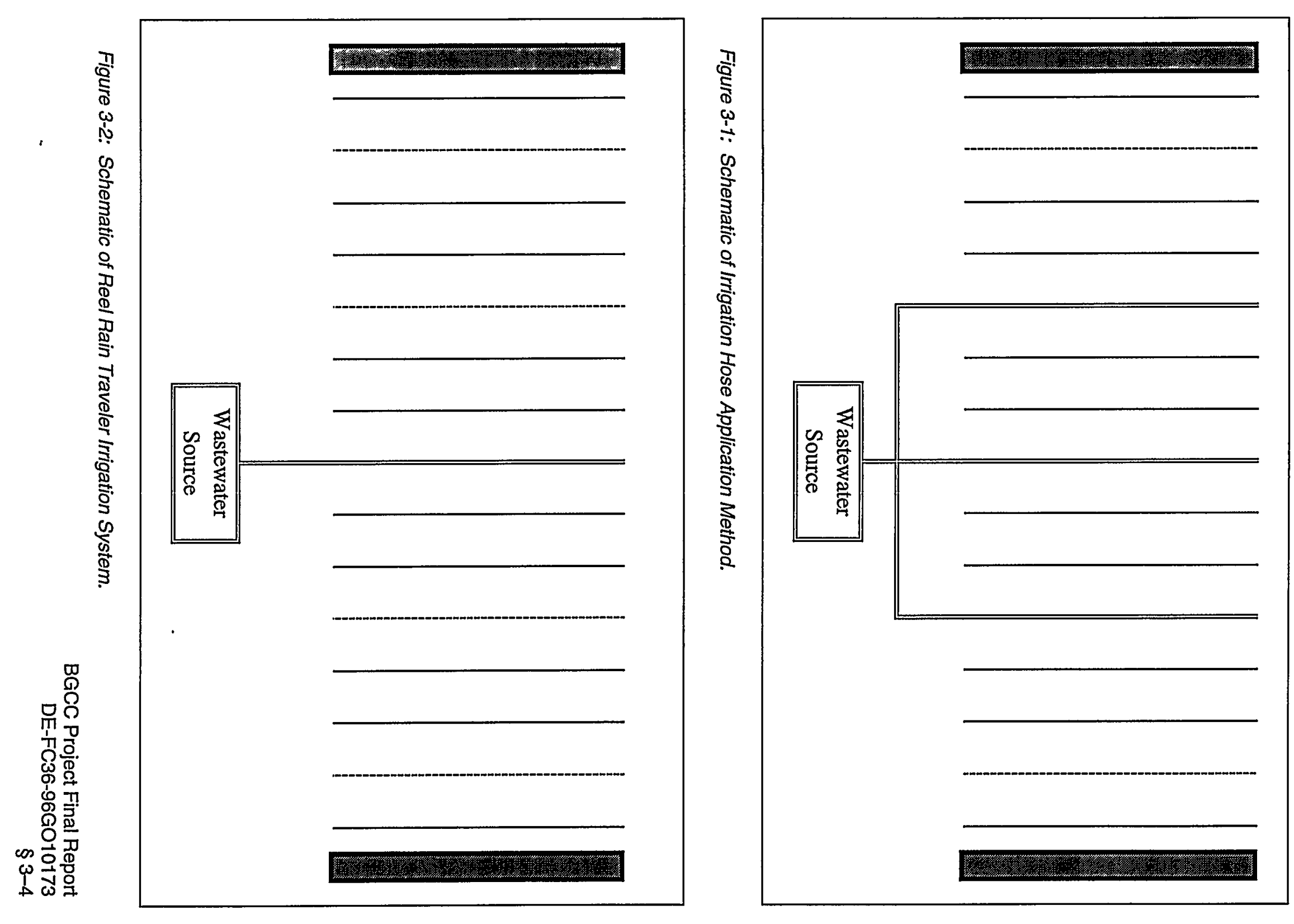


\subsubsection{Monitoring}

The two main objectives of the comprehensive monitoring regime are:

1) to insure that unacceptable levels of nutrients, particularly nitrate, do not occur downstream; and

2) to obtain data representative of the nutrient and hydrologic cycles of the site to compare with the NCSFNC nutrient use model and DRAINMOD as the basis for the hydrologic model.

A complete characterization of the soil-including but not limited to organic matter, $\mathrm{pH}, \mathrm{CEC}$, soil moisture, soil nutrients, permeability, and bulk density-was accomplished prior to application and at yearly increments. Soil nutrient constituents include nitrogen $(\mathrm{N})$, phosphorus $(\mathrm{P})$, potassium $(\mathrm{K})$, magnesium $(\mathrm{Mg})$, calcium $(\mathrm{Ca})$, sulfur (S), zinc ( $\mathrm{Zn})$, Manganese (Mn), iron ( $\mathrm{Fe}$ ), copper (Cu), and boron (B).

The application method delivery systems were located in separate ditch cuts. Any drainage of surface water from the study site was limited by water control structures with downstream sampling to monitor any nutrient loss from the site.

Surface and ground water table levels were monitored along two transects in both ditch cuts. Additionally, ground water monitoring wells were placed at different depths in the soil profile of each plot to measure nutrient concentrations in the soil water.

The outlet riser had a Stevens water level recorder to provide a continuous measurement of water level. Additionally, a Sigma water sampler was used to sample surface water during periods of flow for nutrient analysis.

Loblolly and understory foliage were sampled for weight and nutrient concentrations. Litter traps were used to collect monthly litterfall and estimate leaf area. Tree diameter was measured monthly during the spray season with annual height and diameter recorded at the end of the growing season.

A Davis GroWeather station was placed at the site to record weather data. The high variability of weather patterns and the importance of accuracy dictated this necessity. Additionally, manual rain gauges were strategically placed to act as a check on the electronic gauge and to determine variability across the site.

Statistical Analysis Software (SAS, 1997) was used to analyze relationships between tree growth, various nutrient concentrations, water level, treatment level, and application method. The general linear model procedure was used to test for significant differences among treatments. Duncan multiple range tests were used to separate means by treatment level and application method.

The effluent from the City of New Bern WWTP was analyzed over a period of five years. Average nutrient concentrations over that time were used to simulate a fertilizer with those same characteristics. The fertilizer was manufactured by Encee Chemical, Inc. and is comprised of $4.87 \% \mathrm{~N}, 1.30 \% \mathrm{P}_{2} \mathrm{O}_{5}, 5.05 \% \mathrm{~K}_{2} \mathrm{O}, 80 \mathrm{ppm} \mathrm{Cu}$, and $122 \mathrm{ppm} \mathrm{Zn}$. It has a pH of 1.62 and a density of $1.144 \mathrm{~g} / \mathrm{ml}$. It is diluted at a rate of 1 to 3225 to produce a fertigant with the approximate concentration of $15 \mathrm{ppm}$ $\mathrm{N}, 9.61 \mathrm{ppm} \mathrm{NH}_{3}, 1.76 \mathrm{ppm} \mathrm{P}, 13 \mathrm{ppm} \mathrm{K}, 25 \mathrm{ppb} \mathrm{Cu}$, and $38 \mathrm{ppb} \mathrm{Zn}$. 


\subsection{Results}

\subsubsection{Tree Measurements}

Covariance analysis was used to account for the pretreatment bias in initial tree measurements. Table 3-1-A shows simple height and diameter means for each treatment level and application method. The coefficient of determination, $\mathrm{R}^{2}$, is very high. This signifies that the variation in measurements is accounted for by the model variables; i.e., treatment level, application method and initial measurements. All of the measurements are the greatest in the constant wetting $(6 \mathrm{in} / \mathrm{mo})$ treatment and are followed by control, high volume ( $4 \mathrm{in} / 2 \mathrm{mo}$ ), and high frequency ( $2 \mathrm{in} / \mathrm{mo})$. The trees in the outer four rows, receiving less fertigation water, were significantly larger in height and diameter than those in the inner four rows.

\begin{tabular}{|c|c|c|c|c|c|c|c|}
\hline & & & Measure & nent Date & & & \\
\hline & Jan-98 & Aug-98 & Sep-98 & Oct-98 & Jan-99 & Jun-99 & Aug-99 \\
\hline Height & & & & & & & \\
\hline$R^{2}$ & 0.23 & * & * & * & 0.93 & * & * \\
\hline Treatment Level & & & & & & & \\
\hline High Frequency (2in/mo) & $36.59 \mathrm{~d}$ & \# & * & * & $40.26 \mathrm{~d}$ & * & $\star$ \\
\hline High Volume $(4 \mathrm{in} / 2 \mathrm{mo})$ & $38.53 \mathrm{c}$ & \# & \# & * & $41.78 \mathrm{c}$ & $\star$ & * \\
\hline Constant Wetting (6in/mo) & $42.92 \mathrm{a}$ & \# & * & * & $46.11 \mathrm{a}$ & * & * \\
\hline Control & $41.08 \mathrm{~b}$ & ‡ & * & ๘ & $44.17 \mathrm{~b}$ & * & * \\
\hline Application Method & & & & & & & \\
\hline Irrigation Hose & $40.26 \mathrm{a}$ & * & * & * & $43.36 \mathrm{a}$ & * & * \\
\hline Reel Rain Traveler & $38.95 \mathrm{~b}$ & * & * & * & $42.42 \mathrm{~b}$ & * & * \\
\hline Tree Row & & & & & & & \\
\hline Inner & $38.29 \mathrm{a}$ & $\star$ & $\star$ & * & $42.14 b$ & * & * \\
\hline Outer & $39.61 \mathrm{a}$ & \# & * & \# & $42.91 \mathrm{a}$ & \# & * \\
\hline Diameter & & & & & & & \\
\hline $\mathrm{R}^{2}$ & 0.04 & 0.99 & 0.99 & 0.99 & 0.99 & 0.98 & 0.97 \\
\hline Treatment Level & & & & & & & \\
\hline High Frequency (2in/mo) & $8.42 \mathrm{~b}$ & $8.96 \mathrm{c}$ & $9.01 \mathrm{c}$ & $9.04 \mathrm{c}$ & $8.98 \mathrm{c}$ & $9.38 \mathrm{c}$ & $9.50 \mathrm{c}$ \\
\hline High Volume $(4 \mathrm{in} / 2 \mathrm{mo})$ & $8.41 \mathrm{~b}$ & $8.97 \mathrm{c}$ & $9.01 \mathrm{c}$ & $9.06 \mathrm{c}$ & $9.02 \mathrm{c}$ & $9.40 \mathrm{c}$ & $9.54 \mathrm{c}$ \\
\hline Constant Wetting (6in/mo) & $8.96 \mathrm{a}$ & $9.48 \mathrm{a}$ & $9.52 \mathrm{a}$ & $9.56 \mathrm{a}$ & $9.50 \mathrm{a}$ & $9.88 \mathrm{a}$ & $10.00 \mathrm{a}$ \\
\hline Control & $8.63 \mathrm{ab}$ & $9.20 \mathrm{~b}$ & $9.25 b$ & $9.31 \mathrm{~b}$ & $9.26 \mathrm{~b}$ & $9.67 b$ & $9.79 \mathrm{~b}$ \\
\hline Application Method & & & & & & & \\
\hline Irrigation Hose & $8.80 \mathrm{a}$ & $9.34 \mathrm{a}$ & $9.39 \mathrm{a}$ & $9.44 \mathrm{a}$ & $9.40 \mathrm{a}$ & $9.78 \mathrm{a}$ & $9.90 \mathrm{a}$ \\
\hline Reel Rain Traveler & $8.40 \mathrm{~b}$ & $8.96 \mathrm{~b}$ & $9.00 \mathrm{~b}$ & $9.04 \mathrm{~b}$ & $8.98 \mathrm{~b}$ & $9.38 \mathrm{~b}$ & $9.51 \mathrm{~b}$ \\
\hline Tree Row & & & & & & & \\
\hline$\overline{\text { Inner }}$ & $8.12 \mathrm{a}$ & $8.71 \mathrm{~b}$ & $8.66 \mathrm{~b}$ & $8.69 \mathrm{~b}$ & $8.65 \mathrm{~b}$ & $9.05 \mathrm{~b}$ & $9.19 \mathrm{~b}$ \\
\hline Outer & $8.62 \mathrm{a}$ & $9.16 \mathrm{a}$ & $9.21 \mathrm{a}$ & $9.26 \mathrm{a}$ & $9.21 \mathrm{a}$ & $9.60 \mathrm{a}$ & $9.72 \mathrm{a}$ \\
\hline${ }^{*}$ No measurements were $t$ & ken. & Means V & the sam & etter are & t signific & ly differer & \\
\hline
\end{tabular}

Table 3-1-A: Loblolly pine measurements of height ( $\mathrm{ft}$ ) and $\mathrm{dbh}(\mathrm{in})$ by treatment level and application

Table 3-1-B shows the growth of the trees over the 19-month period. Again, covariance analysis was used. The $\mathrm{R}^{2}$ was very low; however, it is increasing over time for diameter. Interestingly, height and diameter growth show significantly different patterns. Height growth is greatest in the high frequency $(2 \mathrm{in} / \mathrm{mo})$ plots while the control plots exhibit greater diameter growth. Additionally, the inner tree rows show greater height growth while the outer rows exhibit greater diameter growth. Tree spacing was not taken into account. 


\begin{tabular}{|c|c|c|c|c|c|c|c|}
\hline \multicolumn{8}{|c|}{ Measurement Date } \\
\hline & Jan-98 & Aug-98 & Sep-98 & Oct-98 & Jan-99 & Jun-99 & Aug-99 \\
\hline \multicolumn{8}{|l|}{ Height } \\
\hline$R^{2}$ & 0 & * & * & * & 0.06 & * & * \\
\hline \multicolumn{8}{|l|}{ Treatment Level } \\
\hline High Frequency $(2 \mathrm{in} / \mathrm{mo})$ & 0 & * & * & * & $3.63 \mathrm{a}$ & * & * \\
\hline High Volume $(4 \mathrm{in} / 2 \mathrm{mo})$ & 0 & * & $\star$ & * & $3.28 \mathrm{~b}$ & * & * \\
\hline Constant Wetting (6in/mo) & 0 & * & $\star$ & \# & $3.21 \mathrm{~b}$ & * & * \\
\hline Control & $\mathbf{0}$ & * & * & \pm & $3.09 \mathrm{~b}$ & * & * \\
\hline \multicolumn{8}{|l|}{ Application Method } \\
\hline Irrigation Hose & 0 & \# & * & * & $3.07 \mathrm{~b}$ & * & * \\
\hline Reel Rain Traveler & 0 & $\star$ & * & $\star$ & $3.55 \mathrm{a}$ & $\star$ & * \\
\hline \multicolumn{8}{|l|}{ Tree Row } \\
\hline Inner & $\mathbf{0}$ & * & * & * & $3.86 \mathrm{a}$ & * & \# \\
\hline Outer & 0 & * & * & * & $3.29 \mathrm{~b}$ & * & \pm \\
\hline \multicolumn{8}{|l|}{ Diameter } \\
\hline $\mathrm{R}^{2}$ & 0 & 0.08 & 0.14 & 0.17 & 0.17 & 0.17 & 0.18 \\
\hline \multicolumn{8}{|l|}{ Treatment Level } \\
\hline High Frequency (2in/mo) & $\mathbf{0}$ & $0.53 \mathrm{a}$ & $0.58 \mathrm{ab}$ & $0.62 \mathrm{bc}$ & $0.56 \mathrm{~b}$ & $0.96 \mathrm{bc}$ & $1.08 \mathrm{~b}$ \\
\hline High Volume (4in/2mo) & 0 & $0.57 \mathrm{a}$ & $0.60 \mathrm{a}$ & $0.65 \mathrm{ab}$ & $0.59 \mathrm{~b}$ & $1.00 \mathrm{ab}$ & $1.15 \mathrm{a}$ \\
\hline Constant Wetting (6in/mo) & $\mathbf{0}$ & $0.53 \mathrm{a}$ & $0.56 \mathrm{~b}$ & $0.60 \mathrm{c}$ & $0.55 \mathrm{~b}$ & $0.93 \mathrm{c}$ & $1.06 \mathrm{~b}$ \\
\hline Control & 0 & $0.57 \mathrm{a}$ & $0.62 \mathrm{a}$ & $0.68 \mathrm{a}$ & $0.64 \mathrm{a}$ & $1.04 \mathrm{a}$ & $1.16 \mathrm{a}$ \\
\hline \multicolumn{8}{|l|}{ Application Method } \\
\hline Irrigation Hose & 0 & $0.53 \mathrm{a}$ & $0.58 \mathrm{a}$ & $0.64 \mathrm{a}$ & $0.59 \mathrm{a}$ & $0.98 \mathrm{a}$ & $1.11 \mathrm{a}$ \\
\hline Reel Rain Traveler & 0 & $0.56 \mathrm{a}$ & $0.60 \mathrm{a}$ & $0.63 \mathrm{a}$ & $0.58 \mathrm{a}$ & $0.98 \mathrm{a}$ & $1.11 \mathrm{a}$ \\
\hline \multicolumn{8}{|l|}{ Tree Row } \\
\hline Inner & 0 & $0.59 \mathrm{a}$ & $0.53 b$ & $0.56 \mathrm{~b}$ & $0.53 b$ & $0.92 \mathrm{a}$ & $1.06 \mathrm{a}$ \\
\hline Quter & 0 & $0.55 a$ & $0.60 \mathrm{a}$ & $0.64 \mathrm{a}$ & $0.59 a$ & $0.99 \mathrm{a}$ & $1.11 \mathrm{a}$ \\
\hline
\end{tabular}

Table 3-1-B: Loblolly pine growth as measured by change in height (ft) and $\mathrm{dbh}$ (in) and presented by treatment level and application method on Craven 26 fertigation study.

Tree volume measurements and volume growth are represented by $\mathrm{D}^{2} \mathrm{H}\left(\mathrm{ft}^{3}\right)$ and are presented in Table 3-1-C. While the covariance analysis accounts for the pretreatment bias, it is not removed. Therefore, percent growth is also shown. These results demonstrate that high frequency $(2 \mathrm{in} / \mathrm{mo})$ and high volume $(4 \mathrm{in} / 2 \mathrm{mo}) \mathrm{had}$ greater percent growth than the control. The constant wetting $(6 \mathrm{in} / \mathrm{mo})$ treatment level has a significantly lower impact on percent growth. The reel rain traveler had significantly higher percent growth than the irrigation hose method. While outer tree rows had greater growth, inner tree rows had greater percent growth.

\begin{tabular}{|c|c|c|c|c|}
\hline & Jan-98 & Jan-99 & Growth & $\%$ Growth \\
\hline $\mathrm{R}^{2}$ & 0.08 & 0.98 & 0.60 & $\mathrm{n} / \mathrm{a}$ \\
\hline \multicolumn{5}{|l|}{ Treatment Level } \\
\hline High Frequency (2in/mo) & $20.1 \mathrm{c}$ & $25.0 \mathrm{~b}$ & $4.83 \mathrm{~b}$ & 124 \\
\hline High Volume (4in/2mo) & $20.7 \mathrm{c}$ & $25.7 \mathrm{c}$ & $4.90 \mathrm{~b}$ & 124 \\
\hline Constant Wetting (6in/mo) & $26.0 \mathrm{a}$ & $31.3 \mathrm{a}$ & $5.41 \mathrm{a}$ & 120 \\
\hline Control & $23.5 \mathrm{~b}$ & $25.0 \mathrm{~d}$ & $5.47 \mathrm{a}$ & 123 \\
\hline \multicolumn{5}{|l|}{ Application Method } \\
\hline Irrigation Hose & $23.9 \mathrm{a}$ & $29.2 \mathrm{a}$ & $5.24 \mathrm{a}$ & 122 \\
\hline Reel Rain Traveler & $21.1 \mathrm{~b}$ & $26.0 \mathrm{~b}$ & $5.04 \mathrm{a}$ & 123 \\
\hline \multicolumn{5}{|l|}{ Tree Row } \\
\hline Inner & $19.0 \mathrm{~b}$ & $23.7 b$ & $4.62 \mathrm{~b}$ & 124 \\
\hline Outer & $22.6 \mathrm{a}$ & $27.8 \mathrm{a}$ & $5.17 \mathrm{a}$ & 123 \\
\hline
\end{tabular}

Table 3-1-C: Loblolly pine measurements and growth by $D^{2} \mathrm{H}$ (ft3) on Craven 26 fertigation study. 


\subsubsection{Pine Foliage}

Loblolly pine foliage was sampled Fall, 1997, prior to application and again Fall, 1998. Nutrient content data is presented in Table 3-2. The coefficient of determination, adjusted $\mathrm{R}^{2}$, ranged from 0.41 for $\mathrm{Mn}$ to 0.98 for $\mathrm{B}$. There were no significant differences among treatment level or application methods for $\mathrm{N}, \mathrm{P}, \mathrm{K}, \mathrm{Mg}$, $\mathrm{Ca}, \mathrm{B}, \mathrm{Zn}, \mathrm{Mn}, \mathrm{Fe}$, or $\mathrm{Cu}$. Boron (B), $\mathrm{Zn}$, and Fe increased significantly from Fall, 1997, to Fall, 1998.

\begin{tabular}{|c|c|c|c|c|c|}
\hline \multirow{2}{*}{. } & $\mathbf{N}$ & $\mathbf{P}$ & $\mathbf{K}$ & $\mathrm{Mg}$ & $\mathrm{Ca}$ \\
\hline & \multicolumn{5}{|c|}{ 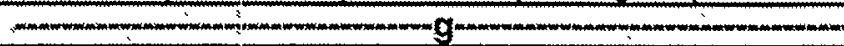 } \\
\hline$R^{2}$ & 0.56 & 0.80 & 0.50 & 0.72 & 0.57 \\
\hline \multicolumn{6}{|l|}{ Treatment Level } \\
\hline High Frequency (2in/mo) & $0.32 \mathrm{a}$ & $0.02 \mathrm{a}$ & $0.10 \mathrm{a}$ & $0.01 \mathrm{a}$ & $0.02 a$ \\
\hline High Volume (4in/2mo) & $0.33 \mathrm{a}$ & $0.03 \mathrm{a}$ & $0.11 \mathrm{a}$ & $0.02 \mathrm{a}$ & $0.02 \mathrm{a}$ \\
\hline Constant Wetting (6in/mo) & $0.30 \mathrm{a}$ & $0.02 \mathrm{a}$ & $0.11 \mathrm{a}$ & $0.01 \mathrm{a}$ & $0.02 \mathrm{a}$ \\
\hline Control & $0.32 \mathrm{a}$ & $0.03 \mathrm{a}$ & $0.11 \mathrm{a}$ & $0.01 \mathrm{a}$ & $0.02 \mathrm{a}$ \\
\hline \multicolumn{6}{|l|}{ Application Method } \\
\hline Irrigation Hose & $0.31 \mathrm{a}$ & $0.02 \mathrm{a}$ & $0.11 \mathrm{a}$ & $0.01 \mathrm{a}$ & $0.02 \mathrm{a}$ \\
\hline Reel Rain Traveler & $0.32 \mathrm{a}$ & $0.02 a$ & $0.10 a$ & $0.01 \mathrm{a}$ & $0.02 a$ \\
\hline \multicolumn{6}{|l|}{ Season } \\
\hline Fall 1997 & $0.30 \mathrm{a}$ & $0.02 \mathrm{a}$ & $0.10 \mathrm{a}$ & $0.01 \mathrm{a}$ & $0.02 \mathrm{a}$ \\
\hline \multirow[t]{3}{*}{ Fall 1998} & $0.34 \mathrm{a}$ & $0.03 \mathrm{a}$ & $0.12 \mathrm{a}$ & $0.02 \mathrm{a}$ & $0.02 \mathrm{a}$ \\
\hline & $\mathbf{B}$ & $2 n$ & Mn & $\mathrm{Fe}$ & Ca \\
\hline & \multicolumn{5}{|c|}{ 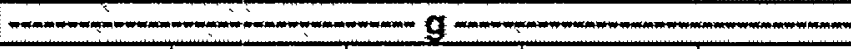 } \\
\hline $\mathrm{R}^{2}$ & 0.98 & 0.62 & 0.41 & 0.76 & 0.67 \\
\hline \multicolumn{6}{|l|}{ Treatment Level } \\
\hline High Frequency ( $2 \mathrm{in} / \mathrm{mo}$ ) & $0.08 \mathrm{a}$ & $0.05 \mathrm{a}$ & $0.09 \mathrm{a}$ & $0.10 \mathrm{a}$ & $0.01 \mathrm{a}$ \\
\hline High Volume (4in/2mo) & $0.08 \mathrm{a}$ & $0.05 a$ & $0.09 a$ & $0.11 \mathrm{a}$ & $0.01 \mathrm{a}$ \\
\hline Constant Wetting (6in/mo) & $0.08 \mathrm{a}$ & $0.05 \mathrm{a}$ & $0.08 \mathrm{a}$ & $0.10 \mathrm{a}$ & $0.01 \mathrm{a}$ \\
\hline Control & $0.09 \mathrm{a}$ & $0.05 a$ & $0.08 \mathrm{a}$ & $0.11 \mathrm{a}$ & $0.02 \mathrm{a}$ \\
\hline \multicolumn{6}{|l|}{ Application Method } \\
\hline Irrigation Hose & $0.08 \mathrm{a}$ & $0.05 a$ & $0.08 \mathrm{a}$ & $0.11 \mathrm{a}$ & $0.01 \mathrm{a}$ \\
\hline Reel Rain Traveler & $0.08 \mathrm{a}$ & $0.05 a$ & $0.08 \mathrm{a}$ & $0.10 a$ & $0.01 \mathrm{a}$ \\
\hline \multicolumn{6}{|l|}{ Season } \\
\hline Fall 1997 & $0.02 b$ & $0.04 \mathrm{~b}$ & $0.09 \mathrm{a}$ & $0.08 \mathrm{~b}$ & $0.01 \mathrm{~b}$ \\
\hline Fall 1998 & $0.15 \mathrm{a}$ & $0.06 \mathrm{a}$ & $0.08 \mathrm{a}$ & $0.12 \mathrm{a}$ & $0.02 \mathrm{~b}$ \\
\hline
\end{tabular}

Table 3-2: Loblolly pine foliar nutrient content on Craven 26 fertigation study

\subsubsection{Litter}

Loblolly pine litter data is presented in Table 3-3-A. The $\mathrm{R}^{2}$ ranges from 0.56 for $\mathrm{Cu}$ to 0.91 for $\mathrm{B}$. Potassium (K), S, and Na vary with treatment level. Potassium was highest in the constant wetting $(6 \mathrm{in} / \mathrm{mo})$ plots. Sulfer (S) and Na were greatest in the control plots.

Other litter includes hardwoods, bushes and forbs. Its nutrient content data is presented in Table 3-3-B. Copper (Cu) varied with treatment level. It was greatest in the constant wetting $(6 \mathrm{in} / \mathrm{mo})$ plots. All of the nutrients were greatest in the irrigation hose plots. 


\begin{tabular}{|c|c|c|c|c|c|c|c|}
\hline & 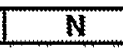 & $\mathbf{P}$ & $\mathbf{K}$ & $\mathbf{s}$ & $\mathrm{Mg}$ & $\mathrm{Ca}$ & $\mathrm{Na}$ \\
\hline $\mathrm{R}^{2}$ & 0.81 & 0.85 & 0.74 & 0.79 & 0.82 & 0.83 & 0.86 \\
\hline \multicolumn{8}{|l|}{ Treatment Level } \\
\hline High Frequency (2in/mo) & $1.18 \mathrm{a}$ & $0.09 \mathrm{a}$ & $0.22 \mathrm{ab}$ & $0.09 \mathrm{ab}$ & $0.08 \mathrm{a}$ & $0.29 \mathrm{a}$ & $0.04 \mathrm{ab}$ \\
\hline High Volume (4in/2mo) & $0.95 \mathrm{a}$ & $0.07 \mathrm{a}$ & $0.20 \mathrm{~b}$ & $0.07 \mathrm{~b}$ & $0.08 \mathrm{a}$ & $0.27 \mathrm{a}$ & $0.03 \mathrm{~b}$ \\
\hline Constant Wetting (6in/mo) & $1.16 \mathrm{a}$ & $0.09 \mathrm{a}$ & $0.26 \mathrm{a}$ & $0.11 \mathrm{ab}$ & $0.08 \mathrm{a}$ & $0.32 \mathrm{a}$ & $0.04 \mathrm{ab}$ \\
\hline Control & $1.26 \mathrm{a}$ & $0.10 \mathrm{a}$ & $0.25 \mathrm{ab}$ & $0.12 \mathrm{a}$ & $0.08 \mathrm{a}$ & $0.31 \mathrm{a}$ & $0.04 \mathrm{a}$ \\
\hline \multicolumn{8}{|l|}{ Application Method } \\
\hline Irrigation Hose & $1.00 \mathrm{~b}$ & $0.07 b$ & $0.22 \mathrm{a}$ & $0.09 \mathrm{a}$ & $0.07 \mathrm{~b}$ & $0.26 \mathrm{~b}$ & $0.03 \mathrm{~b}$ \\
\hline \multirow[t]{2}{*}{ Reel Rain Traveler } & $1.28 \mathrm{a}$ & $0.10 \mathrm{a}$ & $0.25 \mathrm{a}$ & $0.11 \mathrm{a}$ & $0.09 \mathrm{a}$ & $0.33 \mathrm{a}$ & $0.04 \mathrm{a}$ \\
\hline & & $B$ & $\mathrm{Zn}$ & $\operatorname{mn}$ & $\mathrm{Fe}$ & $\mathrm{Cu}$ & Al \\
\hline & & & & & & & \\
\hline$R^{2}$ & & 0.91 & 0.77 & 0.75 & 0.59 & 0.56 & 0.78 \\
\hline \multicolumn{8}{|l|}{ Treatment Level } \\
\hline High Frequency (2in/mo) & & $0.55 \mathrm{a}$ & $0.22 \mathrm{a}$ & $0.51 \mathrm{a}$ & $0.97 \mathrm{a}$ & $0.14 \mathrm{a}$ & $5.16 \mathrm{a}$ \\
\hline High Volume (4in/2mo) & & $0.48 \mathrm{a}$ & $0.19 a$ & $0.48 \mathrm{a}$ & $1.37 \mathrm{a}$ & $0.13 \mathrm{a}$ & $4.99 \mathrm{a}$ \\
\hline Constant Wetting (6in/mo) & & $0.51 \mathrm{a}$ & $0.25 a$ & $0.51 \mathrm{a}$ & $1.27 \mathrm{a}$ & $0.18 \mathrm{a}$ & $5.59 \mathrm{a}$ \\
\hline Control & & $0.52 \mathrm{a}$ & $0.25 a$ & $0.56 \mathrm{a}$ & $1.27 \mathrm{a}$ & $0.18 \mathrm{a}$ & $5.69 \mathrm{a}$ \\
\hline \multicolumn{8}{|l|}{ Application Method } \\
\hline Irrigation Hose & & $0.48 \mathrm{a}$ & $0.20 \mathrm{~b}$ & $0.47 \mathrm{a}$ & $1.03 \mathrm{~b}$ & $0.16 \mathrm{a}$ & $4.63 \mathrm{~b}$ \\
\hline Reel Rain Traveler & & $0.55 \mathrm{a}$ & $0.26 \mathrm{a}$ & $0.56 \mathrm{a}$ & $1.41 \mathrm{a}$ & $0.16 \mathrm{a}$ & $6.09 \mathrm{a}$ \\
\hline Means with the sam & & & & & & & \\
\hline
\end{tabular}

Table 3-3-A: Loblolly pine litter nutrient content on Craven 26 fertigation study

\begin{tabular}{|c|c|c|c|c|c|c|c|}
\hline & $\mathbf{N}$ & $\mathbf{P}$ & $\mathbf{K}$ & $\mathbf{S}$ & $\mathrm{Mg}$ & $\mathrm{Ca}$ & Na \\
\hline & & & 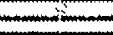 & $-m-$ & & & \\
\hline$R^{2}$ & 0.71 & 0.56 & 0.29 & 0.35 & 0.73 & 0.75 & 0.46 \\
\hline \multicolumn{8}{|l|}{ Treatment Level } \\
\hline High Frequency (2in/mo) & $1.33 \mathrm{~b}$ & $0.07 \mathrm{a}$ & $0.24 a$ & $0.11 \mathrm{a}$ & $0.24 b$ & $0.84 \mathrm{c}$ & $0.04 \mathrm{a}$ \\
\hline High Volume (4in/2mo) & $1.46 \mathrm{ab}$ & $0.10 \mathrm{a}$ & $0.44 \mathrm{a}$ & $0.16 \mathrm{a}$ & $0.26 \mathrm{~b}$ & $0.89 \mathrm{bc}$ & $0.05 a$ \\
\hline Constant Wetting (6in/mo) & $1.52 a b$ & $0.10 \mathrm{a}$ & $0.29 \mathrm{a}$ & $0.14 \mathrm{a}$ & $0.27 \mathrm{~b}$ & $1.05 \mathrm{ab}$ & $0.05 a$ \\
\hline Control & $1.55 \mathrm{a}$ & $0.08 \mathrm{a}$ & $0.25 \mathrm{a}$ & $0.14 \mathrm{a}$ & $0.32 \mathrm{a}$ & $1.09 \mathrm{a}$ & $0.05 \mathrm{a}$ \\
\hline \multicolumn{8}{|l|}{ Application Method } \\
\hline Irrigation Hose & $1.45 \mathrm{a}$ & $0.08 \mathrm{a}$ & $0.27 a$ & $0.12 \mathrm{a}$ & $0.28 \mathrm{a}$ & $0.95 \mathrm{a}$ & $0.05 \mathrm{a}$ \\
\hline Reel Rain Traveler & $1.48 \mathrm{a}$ & $0.10 \mathrm{a}$ & $0.34 \mathrm{a}$ & $0.14 \mathrm{a}$ & $0.26 \mathrm{a}$ & $0.97 \mathrm{a}$ & $0.05 \mathrm{a}$ \\
\hline \multicolumn{8}{|l|}{ Sampling Date } \\
\hline Sep-98 & $1.78 \mathrm{a}$ & $0.14 \mathrm{a}$ & $0.19 \mathrm{~b}$ & $0.18 \mathrm{a}$ & $0.18 \mathrm{c}$ & $0.50 \mathrm{~d}$ & $0.05 a$ \\
\hline Oct-98 & $1.83 \mathrm{a}$ & $0.09 a b$ & $0.36 \mathrm{ab}$ & $0.13 \mathrm{ab}$ & $0.28 \mathrm{~b}$ & $0.89 \mathrm{bc}$ & $0.05 \mathrm{a}$ \\
\hline Nov-98 & $1.17 \mathrm{c}$ & $0.12 \mathrm{a}$ & $0.65 \mathrm{a}$ & $0.17 \mathrm{a}$ & $0.37 \mathrm{a}$ & $1.25 \mathrm{a}$ & $0.05 \mathrm{a}$ \\
\hline Dec-98 & $1.17 \mathrm{c}$ & $0.06 \mathrm{~b}$ & $0.29 \mathrm{ab}$ & $0.09 \mathrm{~b}$ & $0.32 \mathrm{a}$ & $1.22 \mathrm{a}$ & $0.05 \mathrm{ab}$ \\
\hline Jan-99 & $1.35 b c$ & $0.06 \mathrm{~b}$ & $0.13 \mathrm{~b}$ & $0.12 a b$ & $0.27 \mathrm{a}$ & $1.09 \mathrm{ab}$ & $0.03 \mathrm{~b}$ \\
\hline \multirow[t]{3}{*}{ Mar-99 } & $1.52 \mathrm{~b}$ & $0.05 \mathrm{~b}$ & $0.21 a b$ & $0.10 a b$ & $0.21 \mathrm{a}$ & $0.81 \mathrm{c}$ & $0.05 \mathrm{ab}$ \\
\hline & & $\mathbf{B}$ & $\mathrm{Zn}$ & Mh & $\mathrm{Fe}$ & $\mathrm{Cu}$ & AI \\
\hline & & \multicolumn{6}{|c|}{-2} \\
\hline $\mathrm{R}^{2}$ & & 0.92 & 0.66 & 0.65 & 0.44 & 0.54 & 0.48 \\
\hline \multicolumn{8}{|l|}{ Treatment Level } \\
\hline High Frequency (2in/mo) & & $64.31 \mathrm{a}$ & $37.12 \mathrm{~b}$ & $210.33 \mathrm{ab}$ & $148.10 \mathrm{ab}$ & $33.05 \mathrm{a}$ & $244.30 \mathrm{a}$ \\
\hline High Volume (4in/2mo) & & $66.72 a$ & $40.86 \mathrm{~b}$ & $157.92 \mathrm{~b}$ & $219.48 \mathrm{a}$ & $23.65 \mathrm{a}$ & $225.00 \mathrm{a}$ \\
\hline Constant Wetting (6in/mo) & & $64.33 \mathrm{a}$ & $59.65 \mathrm{a}$ & $220.12 a b$ & $185.89 \mathrm{ab}$ & $37.30 \mathrm{a}$ & $287.00 \mathrm{a}$ \\
\hline Control & & $68.05 \mathrm{a}$ & $56.62 \mathrm{a}$ & $253.82 \mathrm{a}$ & $119.89 \mathrm{~b}$ & $45.36 \mathrm{a}$ & $246.00 \mathrm{a}$ \\
\hline \multicolumn{8}{|l|}{ Application Method } \\
\hline Irrigation Hose & & $67.58 \mathrm{a}$ & $50.96 \mathrm{a}$ & $240.77 \mathrm{a}$ & $160.47 \mathrm{a}$ & $36.82 \mathrm{a}$ & $234.75 \mathrm{a}$ \\
\hline Reel Rain Traveler & & $63.95 \mathrm{a}$ & $45.70 \mathrm{a}$ & $177.13 \mathrm{~b}$ & $178.67 \mathrm{a}$ & $32.32 \mathrm{a}$ & $267.47 \mathrm{a}$ \\
\hline \multicolumn{8}{|l|}{ Sampling Date } \\
\hline Sep-98 & & $36.63 \mathrm{c}$ & $34.25 \mathrm{~b}$ & $95.50 \mathrm{~d}$ & $107.38 \mathrm{~b}$ & $14.88 \mathrm{c}$ & $281.25 \mathrm{a}$ \\
\hline Oct-98 & & $18.71 \mathrm{~d}$ & $50.57 \mathrm{a}$ & $162.14 \mathrm{~cd}$ & $224.86 \mathrm{a}$ & $31.71 \mathrm{bc}$ & $191.14 \mathrm{a}$ \\
\hline Nov-98 & & $86.38 \mathrm{~b}$ & $51.50 \mathrm{a}$ & $282.75 \mathrm{a}$ & $203.38 \mathrm{ab}$ & $14.25 \mathrm{c}$ & $238.63 \mathrm{a}$ \\
\hline Dec-98 & & $97.63 \mathrm{ab}$ & $60.38 \mathrm{a}$ & $274.00 \mathrm{a}$ & $134.13 \mathrm{ab}$ & $21.25 \mathrm{c}$ & $248.63 \mathrm{a}$ \\
\hline Jan-99 & & $106.38 \mathrm{a}$ & $65.13 \mathrm{a}$ & $254.88 \mathrm{ab}$ & $230.25 \mathrm{a}$ & $69.38 \mathrm{a}$ & $286.38 \mathrm{a}$ \\
\hline Mar-99 & & $43.23 \mathrm{c}$ & $28.79 \mathrm{~b}$ & $182.55 \mathrm{bc}$ & $123.19 \mathrm{ab}$ & $55.87 \mathrm{ab}$ & $*$ \\
\hline${ }^{\star}$ No measurements were ta & & \multicolumn{5}{|c|}{ Means with the same letter are not significantly different. } & \\
\hline
\end{tabular}

Table 3-3-B: Other litter nutrient concentration on Craven 26 fertigation study 


\subsubsection{Soils}

Soil samples were collected Spring 1998 and Spring 1999. Except for P, soil parameters were well accounted for by the model and produced reasonably high $\mathrm{R}^{2}$. Table 3-4 shows that $\mathrm{K}, \mathrm{Mg}, \mathrm{Ca}, \mathrm{Na}, \mathrm{pH}$, and $\mathrm{CEC}$ significantly increased by the second sampling date. Manganese (Mn) and $\mathrm{Cu}$ significantly decreased over that year. There are no significant differences among treatment level or application method for any of the constituents analyzed.

\begin{tabular}{|c|c|c|c|c|c|c|c|c|c|}
\hline & P & $\bar{K}$ & Mg & $\mathrm{Ca}$ & $\mathrm{Na}$ & $\mathbf{S}$ & $\mathbf{Z n}$ & $\mathbf{M n}$ : & $\mathrm{Cu}$ \\
\hline $\mathrm{R}^{2}$ & 0.31 & 0.84 & 0.96 & 0.89 & 0.93 & 0.56 & 0.63 & 0.78 & 0.68 \\
\hline \multicolumn{10}{|l|}{ Treatment Level } \\
\hline High Frequency (2in/mo) & $33.10 \mathrm{a}$ & $78.91 \mathrm{a}$ & $140.41 \mathrm{a}$ & $1271.5 \mathrm{a}$ & $11.50 \mathrm{a}$ & $41.15 \mathrm{a}$ & $4.03 \mathrm{a}$ & $61.08 \mathrm{a}$ & $4.35 \mathrm{a}$ \\
\hline High Volume (4in/2mo) & $29.85 a$ & $57.88 \mathrm{a}$ & $124.09 \mathrm{a}$ & $778.1 \mathrm{a}$ & $17.25 \mathrm{a}$ & $48.85 \mathrm{a}$ & $3.55 \mathrm{a}$ & $41.83 \mathrm{a}$ & $1.69 \mathrm{a}$ \\
\hline Constant Wetting (6in/mo) & $25.50 \mathrm{a}$ & $78.94 \mathrm{a}$ & $9 \overline{8.24 a}$ & $541.8 \mathrm{a}$ & $11.50 \mathrm{a}$ & $41.25 \mathrm{a}$ & $7.40 a$ & $34.61 \mathrm{a}$ & $1.84 \mathrm{a}$ \\
\hline Control & $39.95 \mathrm{a}$ & $63.08 \mathrm{a}$ & $113.00 \mathrm{a}$ & $825.0 \mathrm{a}$ & $11.50 \mathrm{a}$ & $36.05 \mathrm{a}$ & $14.58 \mathrm{a}$ & $27.28 \mathrm{a}$ & $2.16 \mathrm{a}$ \\
\hline \multicolumn{10}{|l|}{ Application Method } \\
\hline Irrigation Hose & $24.15 \mathrm{a}$ & $49.98 \mathrm{a}$ & $121.61 \mathrm{a}$ & $784.0 \mathrm{a}$ & $14.38 \mathrm{a}$ & $41.40 \mathrm{a}$ & $1.62 \mathrm{a}$ & $22.77 \mathrm{a}$ & $2.12 \mathrm{a}$ \\
\hline Reel Hain Traveler & $39.75 \mathrm{a}$ & $89.42 \mathrm{a}$ & $116.26 \mathrm{a}$ & $924.1 \mathrm{a}$ & $11.50 \mathrm{a}$ & $42.25 \mathrm{a}$ & $13.16 \mathrm{a}$ & $59.64 \mathrm{a}$ & $2.90 \mathrm{a}$ \\
\hline \multicolumn{10}{|l|}{ Season } \\
\hline Spring 1998 & $33.75 \mathrm{a}$ & $20.88 \mathrm{~b}$ & $19.63 b$ & $38.8 \mathrm{~b}$ & $0.00 \mathrm{~b}$ & $37.00 \mathrm{a}$ & $14.42 \mathrm{a}$ & $80.40 a$ & $4.08 \mathrm{a}$ \\
\hline Spring 1999 & $30.15 \mathrm{a}$ & $118.53 \mathrm{a}$ & $218.24 \mathrm{a}$ & $1669.4 \mathrm{a}$ & $25.88 \mathrm{a}$ & $46.65 \mathrm{a}$ & $0.36 \mathrm{a}$ & $2.00 \mathrm{~b}$ & $0.94 \mathrm{~b}$ \\
\hline \multirow[t]{2}{*}{, } & $\mathrm{OM}$ & $\mathrm{pH}$ & $\mathrm{CEC}$ & & & & & & \\
\hline & क: & & $\operatorname{med} 1100 \mathrm{~g}$ & & & & & & \\
\hline $\mathrm{R}^{2}$ & 0.53 & 0.76 & 0.94 & & & & & & \\
\hline \multicolumn{10}{|l|}{ Treatment Level } \\
\hline High Frequency (2in/mo) & $9.95 \mathrm{a}$ & $4.05 \mathrm{a}$ & $11.03 a$ & & & & & & \\
\hline High Volume (4in/2mo) & $9.95 \mathrm{a}$ & $4.05 \mathrm{a}$ & $8.00 \mathrm{a}$ & & & & & & \\
\hline Constant Wetting (6in/mo) & $9.85 \mathrm{a}$ & $4.15 \mathrm{a}$ & $6.80 \mathrm{a}$ & & & & & & \\
\hline Control & $9.56 \mathrm{a}$ & $4.05 \mathrm{a}$ & $8.30 \mathrm{a}$ & & & & & & \\
\hline \multicolumn{10}{|l|}{ Application Method } \\
\hline Irrigation Hose & $9.76 \mathrm{a}$ & $4.06 a$ & $8.38 \mathrm{a}$ & & & & & & \\
\hline Reel Rain Traveler & $9.90 \mathrm{a}$ & $4.09 \mathrm{a}$ & $8.69 \mathrm{a}$ & & & & & & \\
\hline \multicolumn{10}{|l|}{ Season } \\
\hline Spring 1998 & $9.90 \mathrm{a}$ & $4.00 \mathrm{~b}$ & $1.75 \mathrm{~b}$ & & & & & & \\
\hline Spring 1999 & $9.76 \mathrm{a}$ & $4.15 \mathrm{a}$ & $15.31 \mathrm{a}$ & & Means W & he same & tter are $\mathrm{r}$ & cinnific & differen \\
\hline
\end{tabular}

Table 3-4: Soil nutrient concentrations on Craven 26 fertigation study

\subsubsection{Surface Water}

Surface water analyses are presented in Table 3-5. Total nitrogen and total phosphate were not well accounted for by the model. However, they are greatest in the high frequency $(2 \mathrm{in} / \mathrm{mo})$ plots. The high frequency $(2 \mathrm{in} / \mathrm{mo})$ plots also had significantly higher ammonium- $\mathrm{N}$ along with the outlet riser. Ammonium-N was highest in the irrigation hose plots. Nitrate- $\mathrm{N}$ was highest in the constant wetting $(6 \mathrm{in} / \mathrm{mo})$ plots but significantly diluted at the outlet riser. Nitrate- $\mathrm{N}$ was greatest in the traveler plots. 


\begin{tabular}{|l|c|c|c|c|}
\hline & $\mathrm{NH}_{4}-\mathrm{N}$ & $\mathrm{TKN}$ & $\mathrm{NO}_{3} / \mathrm{NO}_{2}-\mathrm{N}$ & $\mathrm{TPO}_{4}$ \\
\hline & \multicolumn{4}{|c|}{} \\
\hline $\mathrm{R}^{2}$ & 0.81 & 0.37 & 0.85 & 0.36 \\
\hline Treatment Level & & & & \\
\hline High Frequency (2in/mo) & $0.06 \mathrm{a}$ & $0.81 \mathrm{a}$ & $0.13 \mathrm{ab}$ & $0.07 \mathrm{a}$ \\
\hline High Volume (4in/2mo) & $0.04 \mathrm{~b}$ & $0.65 \mathrm{a}$ & $0.11 \mathrm{bc}$ & $0.05 \mathrm{ab}$ \\
\hline Constant Wetting (6in/mo) & $0.04 \mathrm{~b}$ & $0.69 \mathrm{a}$ & $0.15 \mathrm{a}$ & $0.05 \mathrm{~b}$ \\
\hline Control & $0.04 \mathrm{~b}$ & $0.30 \mathrm{~b}$ & $0.13 \mathrm{ab}$ & $0.04 \mathrm{~b}$ \\
\hline Outlet & $0.06 \mathrm{a}$ & $0.60 \mathrm{ab}$ & $0.09 \mathrm{C}$ & $0.04 \mathrm{~b}$ \\
\hline Application Method & & & & \\
\hline Irrigation Hose & $0.06 \mathrm{a}$ & $0.71 \mathrm{a}$ & $0.11 \mathrm{~b}$ & $0.05 \mathrm{a}$ \\
\hline Reel Rain Traveler & $0.04 \mathrm{~b}$ & $0.57 \mathrm{a}$ & $0.15 \mathrm{a}$ & $0.05 \mathrm{a}$ \\
\hline Means with the same letter are not significantly different. & \\
\hline
\end{tabular}

Table 3-5: Surface (riser) water nutrient concentration on Craven 26 fertigation study

\subsubsection{Ground Water}

The ground water nutrient concentrations are presented in Table 3-6. Again, total nitrogen and total phosphate were not particularly well accounted for by the model. Total $\mathrm{N}$ was greatest at a depth of 2 feet. Ammonium- $\mathrm{N}$ was highest in the high frequency ( $2 \mathrm{in} / \mathrm{mo}$ ) plots, the traveler plots, and at a depth of 4 feet. Nitrate-N was highest in plots treated with high volume ( $4 \mathrm{in} / 2 \mathrm{mo})$, constant wetting ( $6 \mathrm{in} / \mathrm{mo}$ ), high frequency ( $2 \mathrm{in} / \mathrm{mo}$ ), and control, in that order. Nitrate- $\mathrm{N}$ was highest in the irrigation hose plots and at depths of 2 and 3 feet.

\begin{tabular}{|l|c|c|c|c|}
\hline & $\mathrm{NH}_{4}-\mathrm{N}$ & $\mathrm{TKN}$ & $\mathrm{NO}_{3} / \mathrm{NO}_{2}-\mathrm{N}$ & $\mathrm{TPO}_{4}$ \\
\hline & \multicolumn{4}{|l|}{$\mathrm{ppm}-1$} \\
\hline $\mathrm{R}^{2}$ & 0.86 & 0.51 & 0.87 & 0.51 \\
\hline Treatment Level & & & & \\
\hline \hline High Frequency (2in/mo) & $0.09 \mathrm{a}$ & $0.82 \mathrm{a}$ & $2.21 \mathrm{~b}$ & $0.10 \mathrm{a}$ \\
\hline High Volume (4in/2mo) & $0.07 \mathrm{~b}$ & $1.08 \mathrm{a}$ & $3.60 \mathrm{a}$ & $0.14 \mathrm{a}$ \\
\hline Constant Wetting (6in/mo) & $0.05 \mathrm{c}$ & $0.97 \mathrm{a}$ & $3.41 \mathrm{a}$ & $0.08 \mathrm{a}$ \\
\hline Control & $0.04 \mathrm{c}$ & $0.63 \mathrm{a}$ & $0.65 \mathrm{c}$ & $0.09 \mathrm{a}$ \\
\hline Application Method & & & & \\
\hline Irrigation Hose & $0.05 \mathrm{~b}$ & $1.00 \mathrm{a}$ & $3.09 \mathrm{a}$ & $0.11 \mathrm{a}$ \\
\hline Reel Rain Traveler & $0.07 \mathrm{a}$ & $0.74 \mathrm{a}$ & $1.88 \mathrm{~b}$ & $0.10 \mathrm{a}$ \\
\hline Depth & & & & \\
\hline 2 feet & $0.04 \mathrm{~b}$ & $1.31 \mathrm{a}$ & $3.25 \mathrm{a}$ & $0.13 \mathrm{a}$ \\
\hline 3 feet & $0.06 \mathrm{ab}$ & $0.83 \mathrm{~b}$ & $2.98 \mathrm{a}$ & $0.11 \mathrm{a}$ \\
\hline 4 feet & $0.07 \mathrm{a}$ & $0.64 \mathrm{~b}$ & $1.68 \mathrm{~b}$ & $0.08 \mathrm{a}$ \\
\hline Means with the same letter are not significantly different. & \\
\hline
\end{tabular}

Table 3-6: Ground (well) water nutrient concentration on Craven 26 fertigation study

\subsubsection{Understory Vegetation}

Understory vegetation sampling results were divided into grasses and forbs and are presented in Tables 3-7-A and 3-7-B, respectively. The model did not produce reasonable $\mathrm{R}^{2}$ for any of the nutrients. Nitrogen $(\mathrm{N}), \mathrm{Mg}, \mathrm{Na}, \mathrm{Zn}$, and $\mathrm{Mn}$ had 
significant differences among treatments for grass. They were highest in the high frequency $(2 \mathrm{in} / \mathrm{mo})$ plots and lowest in the constant wetting $(6 \mathrm{in} / \mathrm{mo})$ plots. There were no significant differences in nutrient content for the forbs.

\begin{tabular}{|c|c|c|c|c|c|c|c|}
\hline & $\overline{\mathbf{N}}$ & $\mathbf{S}$ & $p$ & $\bar{K}$ & $\mathrm{Mg}$ & $\mathrm{Ca}$ & $\mathrm{Na}$ \\
\hline & & & & $-g-$ & & & \\
\hline $\mathrm{A}^{2}$ & 0.29 & 0.27 & 0.23 & 0.35 & 0.3 & 0.22 & 0.37 \\
\hline Treatment Level & & & & & & & \\
\hline High Frequency (2in/mo) & $1.69 \mathrm{a}$ & $0.20 \mathrm{a}$ & $0.11 \mathrm{a}$ & $1.01 \mathrm{a}$ & $0.39 \mathrm{a}$ & $0.59 \mathrm{a}$ & $0.33 \mathrm{a}$ \\
\hline High Volume (4in/2mo) & $1.03 \mathrm{ab}$ & $0.14 a$ & $0.08 \mathrm{a}$ & $0.77 \mathrm{a}$ & $0.17 \mathrm{ab}$ & $0.35 \mathrm{a}$ & $0.14 \mathrm{ab}$ \\
\hline Constant Wetting (6in/mo) & $0.25 \mathrm{~b}$ & $0.02 \mathrm{a}$ & $0.02 \mathrm{a}$ & $0.13 \mathrm{a}$ & $0.03 \mathrm{~b}$ & $0.09 \mathrm{a}$ & $0.03 b$ \\
\hline Control & $1.11 \mathrm{ab}$ & $0.14 \mathrm{a}$ & $0.09 \mathrm{a}$ & $0.54 \mathrm{a}$ & $0.13 \mathrm{ab}$ & $0.20 \mathrm{a}$ & $0.16 a b$ \\
\hline Application Method & & & & & & & \\
\hline Irrigation Hose & $0.95 \mathrm{a}$ & $0.11 \mathrm{a}$ & $0.08 \mathrm{a}$ & $0.53 \mathrm{a}$ & $0.20 \mathrm{a}$ & $0.31 \mathrm{a}$ & $0.15 \mathrm{a}$ \\
\hline Reel Rain Traveler & $1.05 \mathrm{a}$ & $0.13 a$ & $0.07 \mathrm{a}$ & $0.68 \mathrm{a}$ & $0.13 a$ & $0.28 \mathrm{a}$ & $0.16 \mathrm{a}$ \\
\hline & & $B$ & $Z_{n}$ & $\mathrm{Mn}$ & $\mathrm{Fe}$ & $\mathrm{Cu}$ & Al \\
\hline $\mathrm{R}^{2}$ & & 0.26 & 0.36 & 0.32 & 0.23 & 0.36 & 0.22 \\
\hline Treatment Level & & & & & & & \\
\hline High Frequency (2in/mo) & & $1.02 \mathrm{a}$ & $0.74 \mathrm{a}$ & $1.49 \mathrm{a}$ & $3.07 \mathrm{a}$ & $0.12 \mathrm{a}$ & $3.48 \mathrm{a}$ \\
\hline High Volume $(4 \mathrm{in} / 2 \mathrm{mo})$ & & $0.83 \mathrm{a}$ & $0.37 a b$ & $1.19 \mathrm{ab}$ & $1.47 \mathrm{a}$ & $0.10 \mathrm{a}$ & $1.95 \mathrm{a}$ \\
\hline Constant Wetting (6in/mo) & & $0.16 \mathrm{a}$ & $0.11 \mathrm{~b}$ & $0.18 \mathrm{~b}$ & $0.88 \mathrm{a}$ & $0.02 \mathrm{a}$ & $0.68 \mathrm{a}$ \\
\hline Control & & $0.71 \mathrm{a}$ & $0.32 \mathrm{ab}$ & $0.68 \mathrm{ab}$ & $0.84 \mathrm{a}$ & $0.05 \mathrm{a}$ & $3.23 \mathrm{a}$ \\
\hline Application Method & & & & & & & \\
\hline Irrigation Hose & & $0.62 \mathrm{a}$ & $0.36 \mathrm{a}$ & $0.84 a$ & $1.44 \mathrm{a}$ & $0.06 \mathrm{a}$ & $1.73 \mathrm{a}$ \\
\hline Reel Rain Traveler & & $0.72 \mathrm{a}$ & $0.39 a$ & $0.89 \mathrm{a}$ & $1.59 \mathrm{a}$ & $0.09 \mathrm{a}$ & $2.98 \mathrm{a}$ \\
\hline & Means w & he same & ter are $n$ & significan & different & & \\
\hline
\end{tabular}

Table 3-7-A: Understory grass vegetation nutrient content on Craven 26 fertigation study

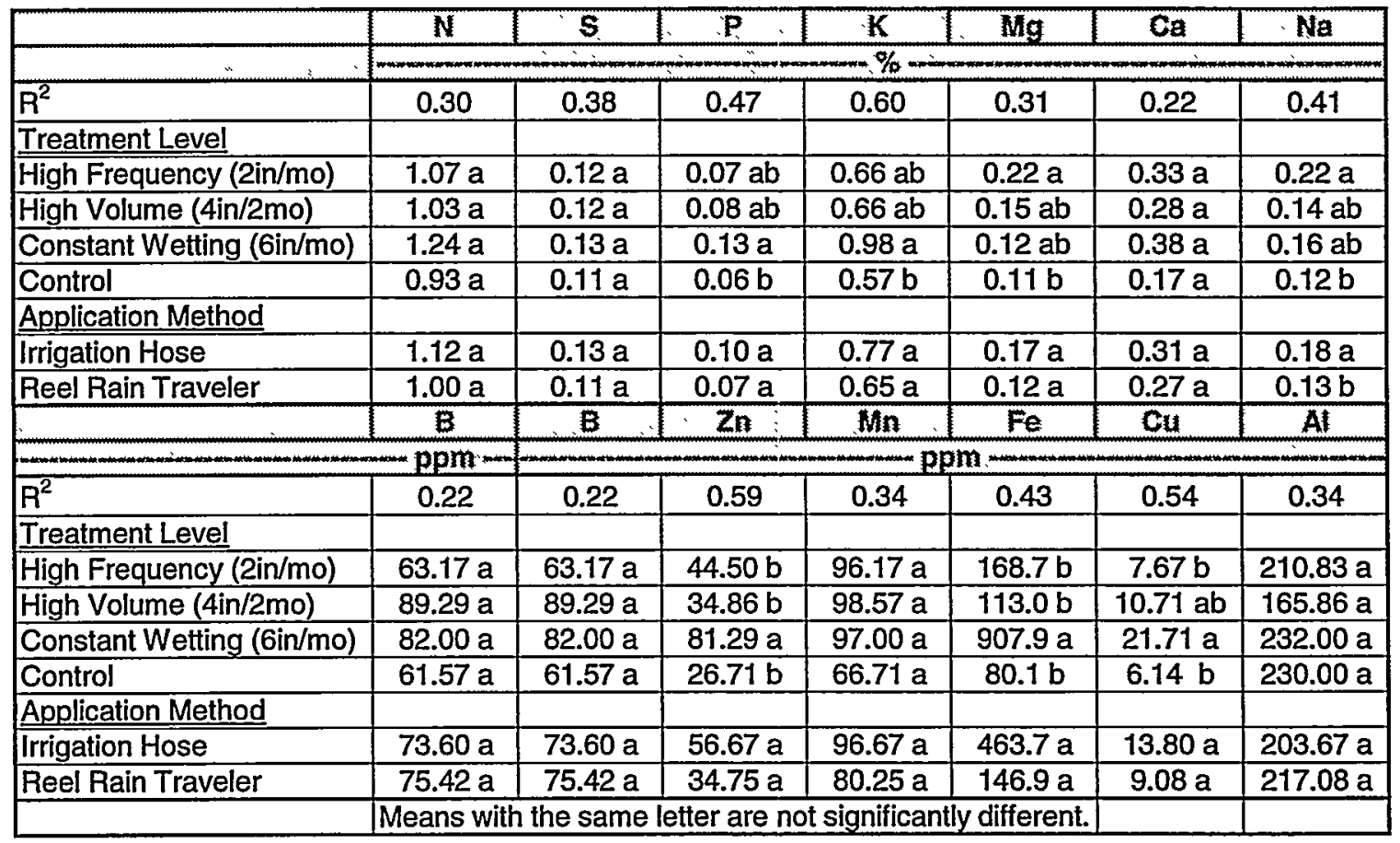

Table 3-7-B: Understory grass vegetation nutrient concentration on Craven 26 fertigation study 


\subsection{Discussion}

The impact of wastewater application on tree growth is not fully understood. One year of data on this trial is not sufficient to determine its total effect. However, using percent growth on the control plots as a base line, initial trends can be identified. The constant wetting $(6 \mathrm{in} / \mathrm{mo})$ treatment has a significantly negative impact. It appears that the high frequency $(2 \mathrm{in} / \mathrm{mo})$ and high volume $(4 \mathrm{in} / 2 \mathrm{mo})$ treatments caused a slight increase in percent growth over the control treatment.

Overall, foliar nutrient contents were not significantly affected by wastewater application. Of the nutrients that increased from 1997 to 1998, only $\mathrm{P}$ and $\mathrm{Cu}$ were added. The other nutrients were either provided by the soil or availability increased with a change in soil $\mathrm{pH}$. With continued application, these values would probably increase over time-particularly in the higher treatment levels. Pine litter nutrient contents will most likely continue the similar trend of increasing for the higher treatment levels.

Soil nutrient concentrations show potential leaching or runoff situations for $\mathrm{P}, \mathrm{Ca}, \mathrm{Mn}$, and $\mathrm{Cu}$ in the constant wetting $(6 \mathrm{in} / \mathrm{mo})$ and high volume $(4 \mathrm{in} / 2 \mathrm{mo})$ treatment regimes. The $\mathrm{pH}$ appears to be increasing with increasing treatment levels.

\subsection{Key Results}

The limited time of tree response is not adequate to make definitive statements. The statistical differences in some of the parameters are surprising; but the effects of the hurricane events, particularly on the constant wetting treatment, may confound the trends.

The pine foliage nutrients do not show strong differences in content or concentrations between treatments. Trends and some specific comparisons do indicate that foliar nutrients are increasing with the nutrient additions. The seasonal comparison and the litter trends reinforce this trend.

Soil nutrient values show seasonal significant increases, although treatment differences are not yet significant.

The understory grass nutrient concentration and content values reflect the differences in nutrient additions. The constant treatment shows increases (significant and non-significant) in nitrogen, sulfur, phosphorus, potassium calcium, sodium, zinc, iron, and magnesium.

Ground water nutrient concentrations of nitrogen forms have significant increases associated with treatments. These trends are also visible at the outlet risers, although NO3/N has the most differences and trends.

\subsection{Conclusions}

The early results from this demonstration trial are beginning to show trends that reflect the treatment differences. This is somewhat unexpected at this stage.

The trends would indicate that tree growth could be increased using nutrients supplied by wastewater. The range of treatments appears to be adequate to cover the range from complete retention of nutrients to some leakage into surface water. 
Continued monitoring of this fertigation project is needed to meet the original goal to quantify the effects of wastewater application on loblolly pine to produce additional energy wood as a co-product of a saw timber rotation.

\subsection{Literature Cited}

Amatya, D., Gilliam, J.W., Skaggs, R.W., and Blanton, C.D.; 1996

Gilliam, J.W.; 1995

Keefer, G.B., and M.W. Gilliland. 1985. Land application of domestic wastewater, wood production, and sludge composting: An integrated design. Resources and Conservation, 12: 13-27.

Skaggs, R.W.; 1978. A water management model for shallow water table soils. Report No. 134, Water Resources Research Institute of the University of N.C.

Statistical Analysis Software; 1997. Release 6.12. SAS Institute, Inc., Cary, NC. 


\section{Section 4}

\section{Gasifier Island Design \& Cost}




\subsection{Gasifier Island Design \& Cost}

This section discusses the design and cost of a gasification island for integration into a market pulp mill. The Weyerhaeuser mill at New Bern, North Carolina, is used as the focus of the study. The technology utilized is Battelle's dual-bed Low Inlet Velocity Gasification (LIVG) process, licensed by Future Energy Resource Corporation (FERCO).

The FERCO gasifier would be used to gasify the waste biomass typically available on and around the facility as described in Section 2. It would be used to generate sufficient medium Btu gas to reduce the quantity of No. 6 fuel oil used in the kiln and power boilers.

In support of this activity, Nexant (a Bechtel Technology and Consulting Company) was asked to develop a conceptual design, including capital cost estimates, that would concentrate on the design, constructability, and capital costs associated with the gasification island. It was agreed that this evaluation would be accomplished in two phases.

The first phase was completed in mid-1999 and covered the design and capital cost estimate for a generic greenfield commercial-size gasification facility. The technology was assumed to be mature or "Nth plant" in order to determine the commercial feasibility of the technology. Significant effort was expended on examining the impact of operating parameters, such as gasifier feed moisture, on overall plant performance. Based on these results, a plant configuration was established and a "Class 40 " capital cost estimate was prepared. (A further clarification of "Class 40 " is found on page $\$ 4-4,4.2 .5$ )

The second phase also examined the impact of key operating parameters but included their effect on capital cost as well as on performance of the gasification island. Since the capital costs developed in the first phase had illustrated the considerable impact the dryer has on the overall plant cost, the second phase included the evaluation of drying options. Also included was an estimate of the capital cost for a first-of-a-kind, or "next plant" cost, as compared to the "Nth plant" costs developed during the first phase. Where possible, the revised work also incorporated information from FERCO's demonstration plant in Burlington, Vermont, to fine tune some of the chemistry, throughput, and operational issues that have not been demonstrated to date at the larger scale. Unfortunately, this was limited due to restricted operation of the Burlington plant during this phase.

The results from Bechtel's work on Phase 2 have been incorporated into an overall conceptual design and cost estimate by Stone \& Webster Engineering Corporation (SWEC). This estimate will include BOP elements and interface to the existing onsite facilities at the New Bern site and is reported in Section 5.

\subsection{Approach to Cost/Performance Analysis}

The work carried out under Phase 2 built on the results and findings from Phase 1. Because of the critical nature that the choice of dryer type and the operating parameters have on the Gasifier Island, a significant amount of effort in Phase 2 was directed to determining the optimum dryer configuration. Since a steam dryer was used in Phase 1, sufficient information was available to carry out the steam dryer portion of the analysis. Therefore, the initial work in Phase 2 was directed at determining the size, configuration, operating 
conditions, and capital cost for a rotary dryer operating off heat from the combustor flue gas. Included in this analysis was a determination of what downstream equipment would be required to clean the wet flue gas leaving the dryer.

Typical operating conditions for the rotary dryer under various design scenarios were provided by M-E-C Company. This data was introduced into the gasifier process model to provide performance data that more closely reflected actual operating practice. The process portion of the model for the steam dryer/gasifier system was unchanged except to add the option of using a constant steam flow to the gasifier. Both models were enhanced to be able to provide scaled capital costs using the costs developed in Phase 1 as a basis.

\subsection{New Bern Mill Specifications \& Design Basis}

The key general and economic criteria used to develop the design of the gasifier island are described below.

\subsubsection{General Criteria}

The general study criteria are as follows:

- Designs are based on FERCO's dual-bed LIVG biomass gasification process developed by Battelle

- Plant is a grassroots facility

- Design of the gasifier island components emphasize minimizing capital cost wherever prudent

- Nth plant perspective was used in the base design

- Product gas from the gasifier was assumed to be used to replace No. 6 fuel oil in existing boilers and kiln

\subsubsection{Site-related Conditions}

The study site is located at Weyerhaeuser's New Bern Mill facility in North Carolina. The site is clear and level with no unusual problems due to soil conditions; however, 60 -foot pile foundations are assumed required based on previous work at the site.

\subsubsection{Meteorological Data}

Annual average ambient air conditions assumed for material balances, thermal efficiencies, and equipment sizing are:

- Dry bulb temperature $60^{\circ} \mathrm{F}$

- Atmospheric pressure $14.7 \mathrm{psia}$ 


\subsubsection{Technical Data.}

The technical data used include:

- The plant capacity is 420 million Btu/hr of product gas, as set by the size of the fuel feed dryer

- The design biomass feed is a combination of hogged fuel, wood residuals, and sludges; a representative analysis is presented in Tables 4-1 through 4-3.

- Gasifier yields are based on Battelle data from their 8- and 10-inch diameter pilot plant gasifier operations. Typical product gas analysis used for this study is presented in Table $4-4$

Heating value, HHV $=8,800$ Btu/lb. (dry basis)
\begin{tabular}{|l|c|}
\hline Component & Weight \% \\
\hline Moisture & 50.0 \\
\hline Carbon & 25.1 \\
\hline Hydrogen & 2.7 \\
\hline Nitrogen & 0.1 \\
\hline Oxygen & 20.1 \\
\hline Ash & 2.0 \\
\hline Total & 100.0 \\
\hline
\end{tabular}

Table 4-1: Design Biomass Feed Analysis

\begin{tabular}{|l|c|}
\hline Size Fraction & 'Weight \%' \\
\hline$+29 \mathrm{~mm}$ & 7.9 \\
\hline $29-22 \mathrm{~mm}$ & 14.6 \\
\hline $22-16 \mathrm{~mm}$ & 23.0 \\
\hline $16-10 \mathrm{~mm}$ & 26.3 \\
\hline $10-5 \mathrm{~mm}$ & 15.9 \\
\hline Pan & 12.3 \\
\hline Total & 100.0 \\
\hline
\end{tabular}

Table 4-2: Design Biomass Size, Williams Classification

\begin{tabular}{|l|c|}
\hline Component & Weight \% \\
\hline Chips & 22.5 \\
\hline Chip fines & 6.5 \\
\hline Forest residue & 71.0 \\
\hline Total & 100.0 \\
\hline
\end{tabular}

Table 4-3: Design Biomass Source Distribution

\begin{tabular}{|l|c|c|}
\hline \multicolumn{1}{|c|}{ Component } & $\begin{array}{c}\text { Dry Gas } \\
\left(\mathbf{N}_{2} \text { Free }\right)\end{array}$ & $\begin{array}{c}\text { Contribution to } \\
\text { Heating Value }\end{array}$ \\
\hline $\mathrm{H}_{2}$ & Volume $\%$ & Btu/SCF \\
\hline $\mathrm{CO}$ & 17.5 & 56.9 \\
\hline $\mathrm{CO}_{2}$ & 50.4 & 161.9 \\
\hline $\mathrm{CH}_{4}$ & 9.4 & -- \\
\hline $\mathrm{C}_{2} \mathrm{H}_{4}$ & 15.5 & 156.9 \\
\hline $\mathrm{C}_{2} \mathrm{H}_{6}$ & 6.1 & 97.8 \\
\hline Calculated Heating Value $=493.0$ & 19.5 \\
\hline
\end{tabular}

Table 4-4: Typical Product Gas Analysis, Dry Basis 
- The level of product gas cleaning is consistent with use in a distributed gas system typically found at pulp and paper facilities. This includes bulk solids removal and scrubbing residual tar leaving the tar cracker. The design temperature of the product gas leaving the gasifier island is $125^{\circ} \mathrm{F}$, as agreed between SWEC, Weyerhaeuser, and Nexant. While this temperature minimizes the size of the product gas compressor, a more detailed analysis would likely show that a higher temperature would provide an economic optimum between the product gas cleanup system and product gas compressor.

- All heat and material balances are based on a feed with 50 percent moisture.

- Sand is delivered to the site by truck equipped with self-contained pneumatic. unloading equipment. Fresh sand is nominally $50 \mathrm{mesh}$ and free of oversize and fine dust.

- Tar yield is $1.0 \%$ of dry wood based on Battelle report, May 1988.

- Sparing philosophy: Online spares for rotating equipment at critical locations with severe duty conditions.

- Plant steam level is $850 \mathrm{psig} / 825^{\circ} \mathrm{F}$.

- Extraction steam from the turbine generator is at 155 psig, while exhaust is at 55 psig.

\subsubsection{Capital Cost Criteria.}

The estimating approach and the engineering information provided to support the estimate are generally consistent with an EPRI Class II, Preliminary Estimate, as defined in EPRI's Technical Assessment Guide, (EPRI TR-102275-VIR7, Volume 1: Rev. 7, June 1993). Based on early discussions with Weyerhaeuser, it was agreed that this level of detail is consistent with Weyerhaeuser's Class 40 evaluation. Cost data are based on a January 1999 price level.

\subsubsection{Qualifications}

The capital cost estimate was developed based on the following qualifications:

- Nth plant perspective was used.

- All major foundations rest on piles. Allowed pre-cast concrete piles with average length - $60 \mathrm{LF}$.

- A 120 foot long pipe/utility bridge is provided to link the Fuel Dryer and Gasification equipment with the rest of the plant.

- All pipe runs and electrical cables to/from unit are above ground.

- Price levels are generally $1^{\text {st }}$ Quarter- 1999 . There is no milestone schedule, so no allowance for price/wage escalation has been provided. Project duration would probably be about 24 months. 
- Engineering, Procurement, and other management/administration costs ("Home Office Cost") have been estimated as a percentage of the constructed cost of the plant. The percentage used is typical for process plants in this cost range and does not allow for additional effort associated with incorporating new technology and lessons learned from the demonstration plant into the design for a commercial plant.

\subsubsection{Direct Field Material Costs}

Direct field material costs are for permanent physical plant facilities including equipment, material, and freight. The local sales tax is excluded.

\subsubsection{Direct Field Labor Costs}

The components of direct field labor costs are labor manhours and the composite labor wage rate.

Manual labor average "all-in" wage rate $(\$ 21.50)$ was used. There is no allowance for travel or per diem for manual labor, because the construction peak is expected to be less than 100 people.

\subsubsection{Direct Subcontract Costs}

Direct subcontract costs are those for equipment, materials, and services furnished by the subcontractors, including installation labor costs and related indirect field costs.

Major items that were estimated as subcontract costs include:

- Dryer assembly

- Refractory

- Insulation, painting, and personnel protection

\subsubsection{Indirect Field and Home Office Engineering Costs}

Indirect field costs are costs that cannot be directly identified with any construction operation related to specific plant facilities but they support the general construction operation.

Based on previous experience at the New Bern Mill, the ratio of indirect to direct manual hours is typically less than $10 \%$ of the contractor's work; $20 \%$ has been used in order to allow for the cost of scaffolding and cleanup. Construction indirect material costs were estimated at $\$ 8 /$ manual hour, which is also consistent with the previous jobs at New Bern.

Field nonmanual hours were estimated as $20 \%$ of manual hours. The average cost of $\$ 25$ per hour was used for nonmanual labor while the combination of nonmanual travel, relocation, and per diem was estimated at $\$ 2.25 /$ nonmanual hour.

Home office engineering manhours and other home office services are accounted for by Bechtel through the addition of $15 \%$ of the Field Costs based on historical data for plants of this size. No special allowances were provided for New Technology for the base estimate. Also included is 5\% of the Total Field Cost and 5\% of the Engineering Cost to cover contractor's fee. 


\subsection{Plant Description}

A brief description of the major systems is provided below. The basic system closely follows the configuration developed by Battelle and employed by FERCO at the Burlington Demonstration Facility. A process flow diagram for the commercial application of the LIVG process used for this evaluation is shown in Figure 4-1, Figure 4-2, and Figure 4-3. The material balance associated with these figures is presented in Table 4-5 (three sheets).

\subsubsection{Fuel Feed and Drying Systems}

Raw wood residuals from the storage yard are reclaimed and transported to a drying plant surge bin, which is included in the BOP. This system is discussed in Section 5. The raw feed is transported to the steam dryer by a rotary feeder and screw conveyor. A knife gate is installed between the rotary feeder and the surge bin to permit isolation of the surge bin from down-stream equipment.

During the passage through the screw conveyor, the wet chips are preheated by waste steam coming from down-stream equipment. The screw conveyor delivers the warmed wet wood residuals to the first of 16 internal drying cells within the Niro steam dryer.

The Niro Steam Drying System is provided as a package that includes:

- Dryer feed end rotary valve

- Dryer feed screw conveyor

- Steam dryer

- Dryer discharge screw conveyor

- Dryer discharge end rotary valve

- Dryer discharge end knife gate

- Flash vessel

- Flash vessel discharge rotary feeder

The Niro dryer uses superheated IP steam as the source of heat. IP steam at approximately $309 \mathrm{psig}$ and $464^{\circ} \mathrm{F}$ is supplied to the dryer from the flue gas HRSG in the gasification section. The condensate from the IP steam (which never contacts the wood residuals and thus remains clean) is recovered and is pumped back to the flue gas HRSG.

The steam used to dry the wood is actually the steam released from the wood that has been superheated in the central exchanger and recirculated within the dryer by a circulating fan located at the bottom of the dryer. Excess steam is released at the top of the dryer through a pressure control system nominally set at $40 \mathrm{psig}$. At steady state, the quantity of process steam leaving the dryer equals the amount of water evaporated from the wet wood residuals. A predetermined amount of the process steam is sent to the Gasifier where it serves to fluidize the solids and control sand flow in the $\mathrm{L}$ valve. The remaining steam is condensed and sent to water treatment using partially heated cooling water from the product gas scrubber cooler. 
A screw conveyor collects the dried wood residuals from the dryer. A rotary valve, similar in construction to the feed end valve, delivers the solids at atmospheric pressure to a combination flash vessel and cyclone collector to separate solids from the gases, mainly steam.

During normal operation, the dried solids are transported by a reversible screw conveyor and high angle conveyor to a live-bottom surge bin containing six discharge screws. A collecting screw gathers the dried wood and transports it to the rotary valve, which feeds the wood residuals to a water-cooled screw that, in turn, feeds the gasifier. The screw feeder is installed in a declined position of about 15 degrees to assist flow of dried feed into the gasifier.

This reversible screw conveyor permits diversion of wood residuals to either the gasifier or the dried wood storage. The dried wood storage bin is a Flo-Matic ${ }^{\circledR}$ bin with about 4 hours capacity at full feed rates. When required, a reclaim conveyor returns the wood chips to the high angle conveyor and live-bottom surge bin for use in the gasifier.

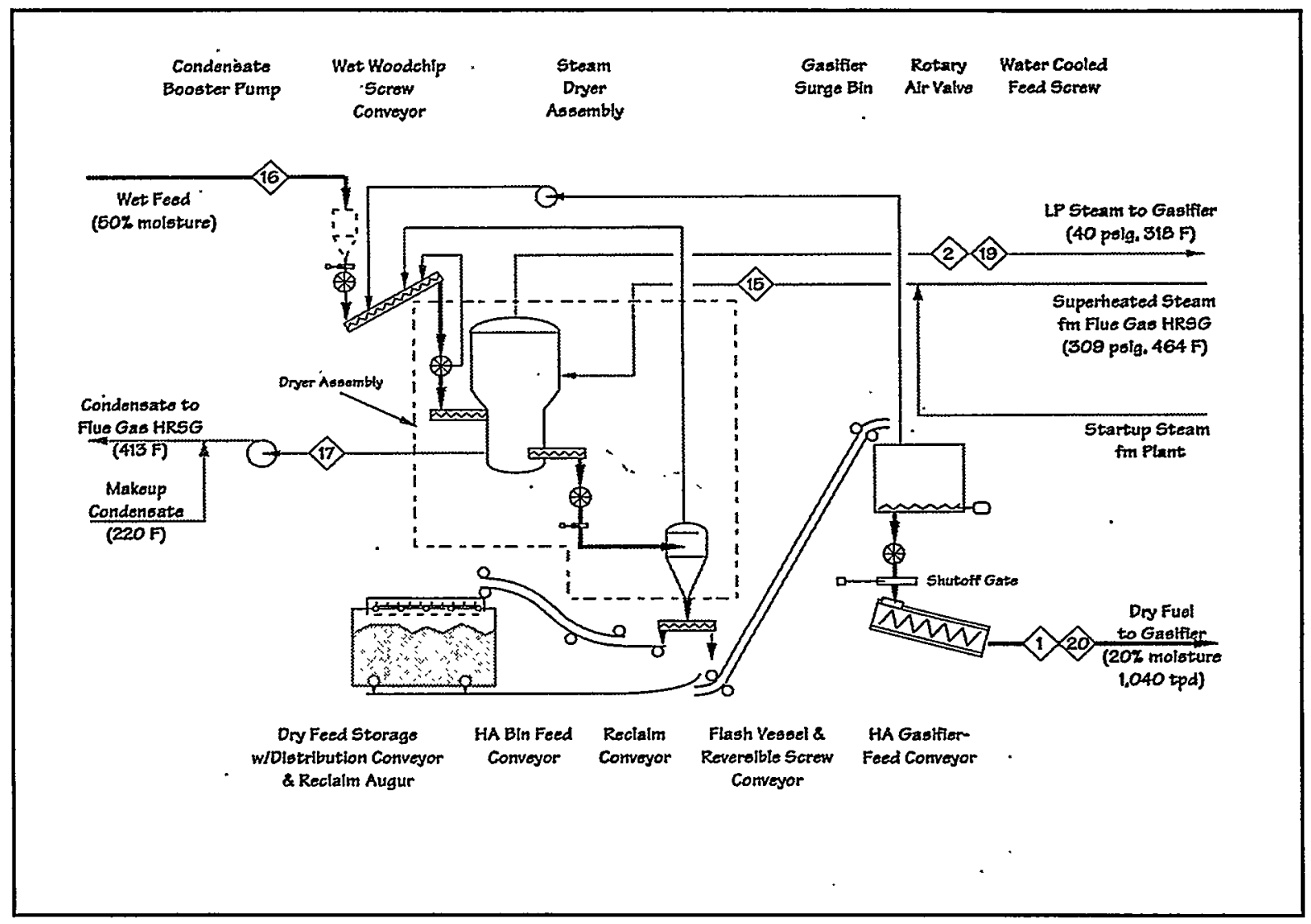

Figure 4-1: Feed Preparation

\subsubsection{Gasifier/Combustor System}

The process configuration for the gasifier and combustor systems closely resembles the system being demonstrated at the Burlington facility. A dual bed system is used with both a gasifier and combustor. Biomass entering the gasifier is heated to pyrolysis temperatures (nominally $1500^{\circ} \mathrm{F}$ ) with hot sand from the combustor. The 
gasifier is an entrained bed design with steam providing the motive force at the bottom of the vessel.

The partially cooled sand is separated from the product gas in a cyclone and is returned to the bottom of the combustor along with unconverted wood in the form of char. Air is provided by high-pressure blowers to fluidize the combustor and provide oxygen for the char combustion. Combusting the char reheats the sand to about $1800^{\circ} \mathrm{F}$, which is separated from the hot flue gas in a cyclone and returned to the gasifier, thereby completing the circuit.

Although the basic elements are the same, several modifications were made to simplify the system, reduce capital cost, or take into account some of the operating experience gained at the Burlington facility. Following the system more or less from beginning to end, the changes include:

- The external startup burners used at Burlington have been replaced with burners close coupled to the Gasifier and Combustor windboxes. The burners have been sized to provide sufficient heat to heat the incoming air to $1500^{\circ} \mathrm{F}$ for faster startup.

- The current study assumed that a dashpot/L-valve and a J-valve can be used to control solids circulation in the gasifier-combustor loop. The J-valve system would be similar to those used in CFB boilers. There is currently some concern on the integrity of such a seal since it will have to maintain a seal between product gas and flue gas with low levels of oxygen. However, for the Nth plant it has been assumed that these concerns will be overcome and the simpler and less expensive J-valve system will be acceptable practice.

- The secondary combustor cyclone at Burlington has been removed. Currently CFB boilers operate with a heat recovery system following a single cyclone and the LIVG process should be able to do the same. The only difference is the high level of quartz sand which is more erosive than coal ash; but based on discussions with HRSG vendor Deltak, it is believed that these difficulties can be overcome through proper design, materials, and reduced velocities.

- A HRSG replaces the quench system used at Burlington. It is assumed that the HRSG would be configured similar to the back end of a CFB boiler running top to bottom where any sand knocked out of the flue gas would be collected. In CFBs this is typically only about $5-10 \%$, with the bulk of the solids continuing with the flue gas to an ESP. If the solids prove too much for the ESP, the secondary cyclone will have to be added back in.

- Since the HRSG uses only a portion of the heat in the flue gas, a combustor air heater has been added down stream of the HRSG to recover the remaining heat. 


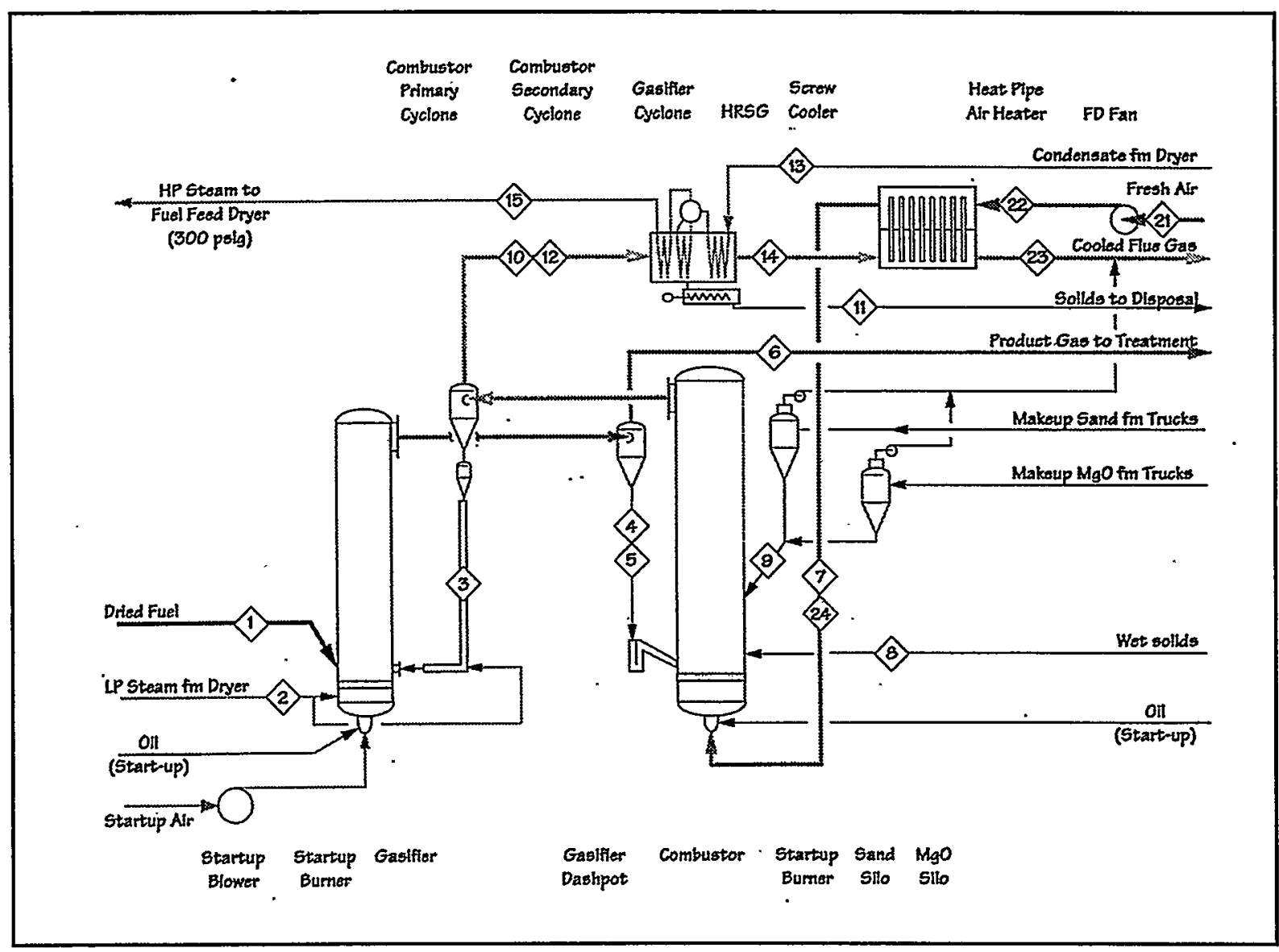

Figure 4-2: Gasification/Combustion

\subsubsection{Product Gas Clean-up System}

The product gas leaving the gasifier cyclone is sent directly to a tar cracker designed by Battelle. Battelle indicates that roughly $90 \%$ of the tar will be cracked to carbon monoxide and hydrogen. For the purpose of this work, it has been assumed that sufficient tar will be cracked to prevent problems in the scrubbing system and downstream equipment.

A product gas HRSG replaces the product gas quench system installed at Burlington to recover the heat and reduce the temperature to $300^{\circ} \mathrm{F}$ prior to entering the scrubber system. Steam is generated at plant conditions and added to the HP steam header.

Since it is not clear what the makeup of the gas stream leaving the tar cracker might be, the scrubbing system provided is essentially the same as the one used at Burlington. However, it is believed that in the commercial application a simpler system may be used to remove particulates (sand, ash, and carbon) and condense out the majority of the water. This would most likely be in the form of a Venturi scrubber without the column. Without the tar phase, the settling and recirculation tanks could also be simplified.

For Phase 2 , the gas leaving the scrubber is cooled to $125^{\circ} \mathrm{F}$ as requested by SWEC to minimize the power required by the product gas compressor. Unfortunately, at $125^{\circ} \mathrm{F}$ 
the duty on the scrubber cooler is about 50 percent greater than the close temperature approach which means that the size-and hence, cost-are increased several fold. While it was agreed to use the lower temperature for this phase, any future work should determine what temperature would provide an economic optimum between the two systems. While not determined, based on discussions with SWEC it is expected that this will be in the range of $135^{\circ} \mathrm{F}$ to $145^{\circ} \mathrm{F}$.

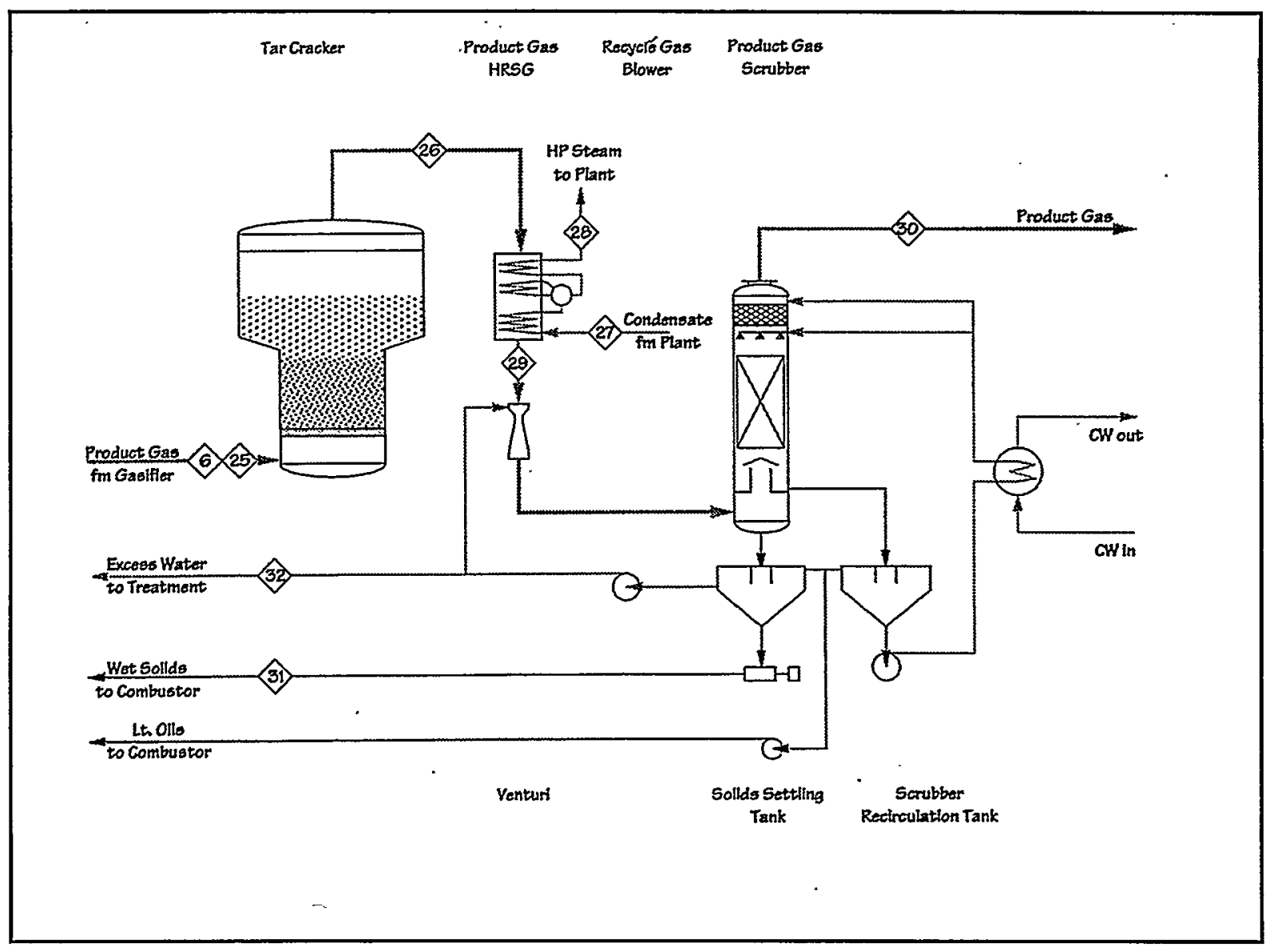

Figure 4-3: Product Gas Clean-up 


\section{Table 4-5}

Major Process Flow Streams - Weyerhaeuser / LIVG Gasifier Moisture in Feed $=\mathbf{2 0} \%$ with Controlled Steam to Gasifier

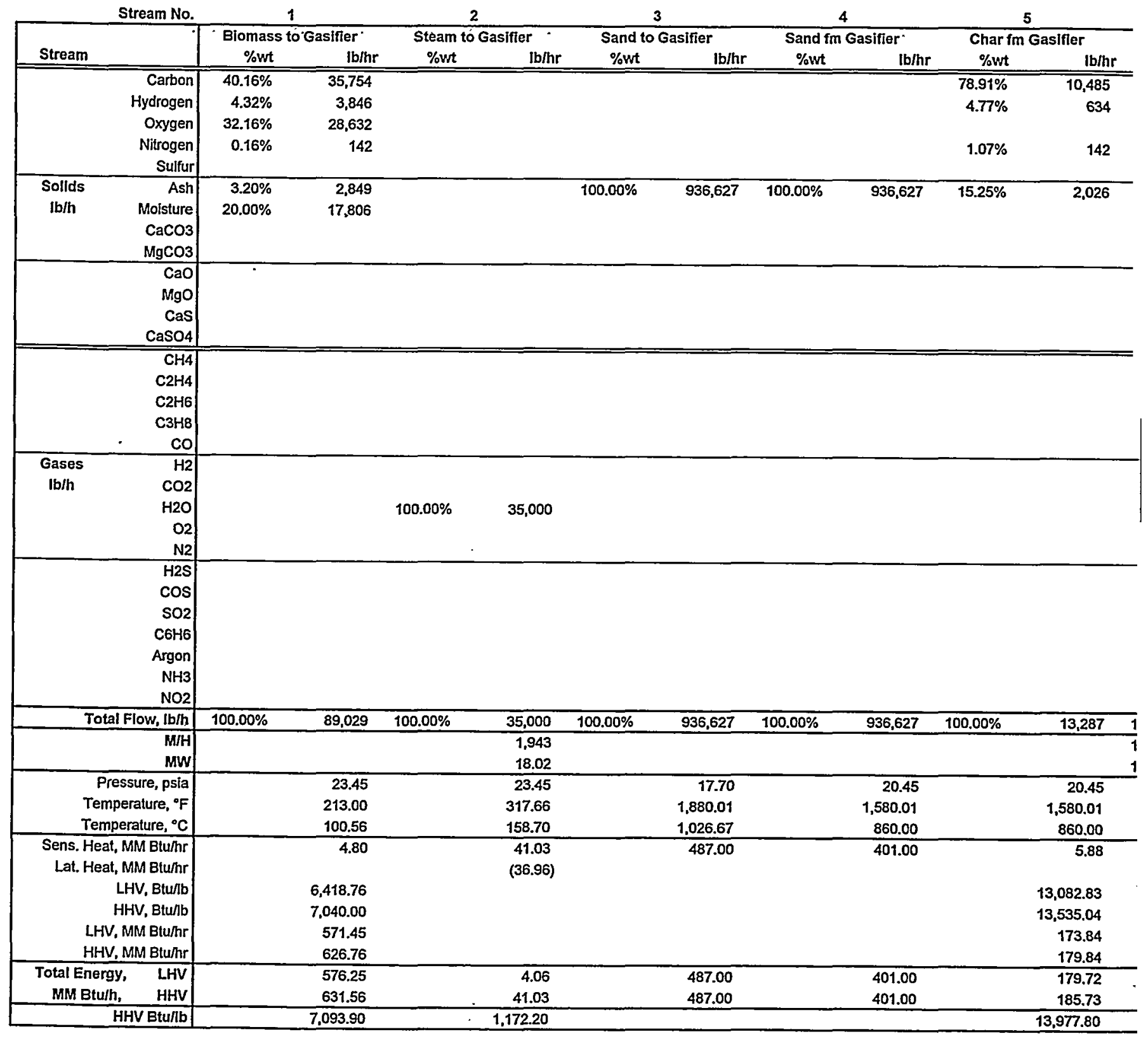




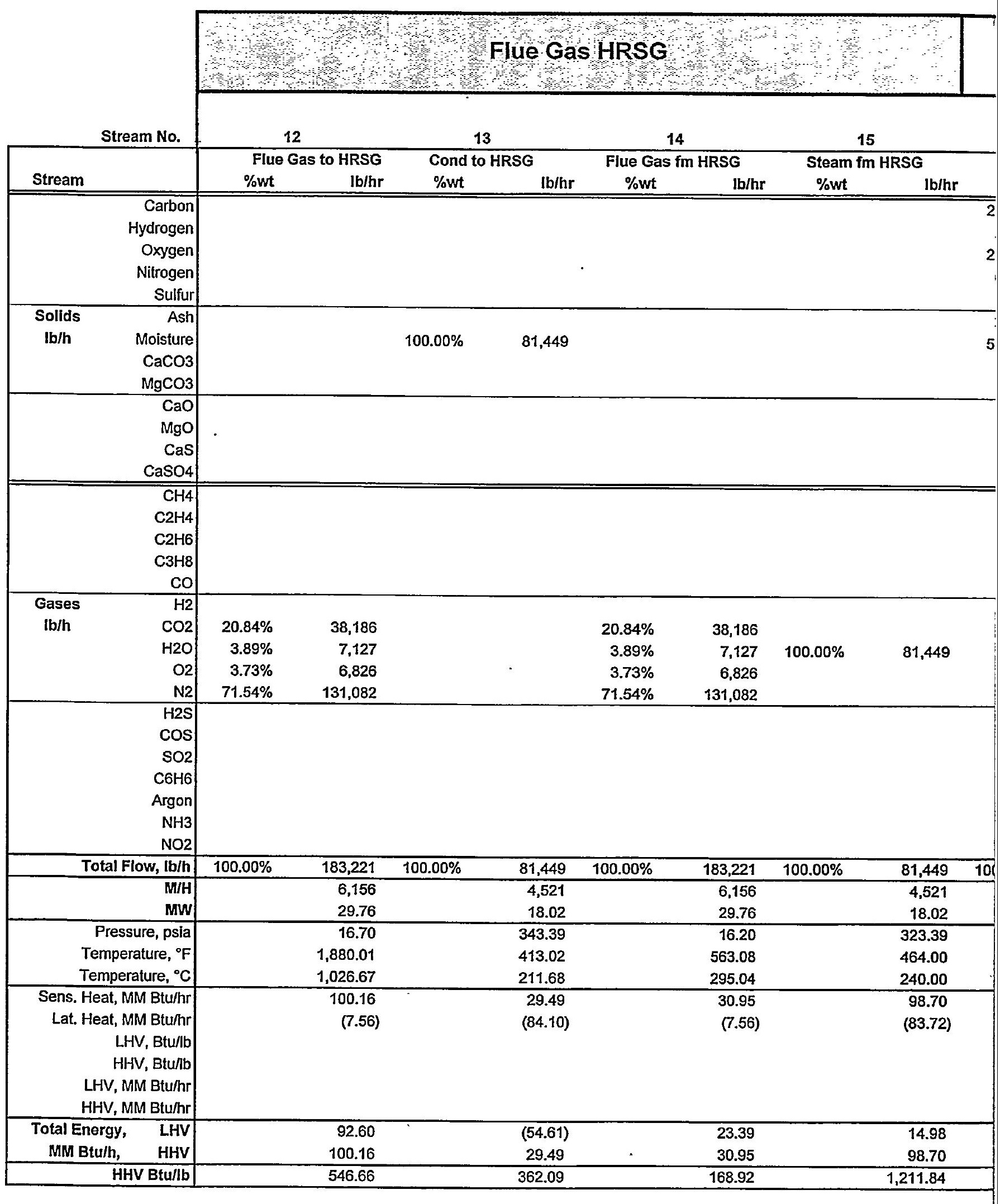




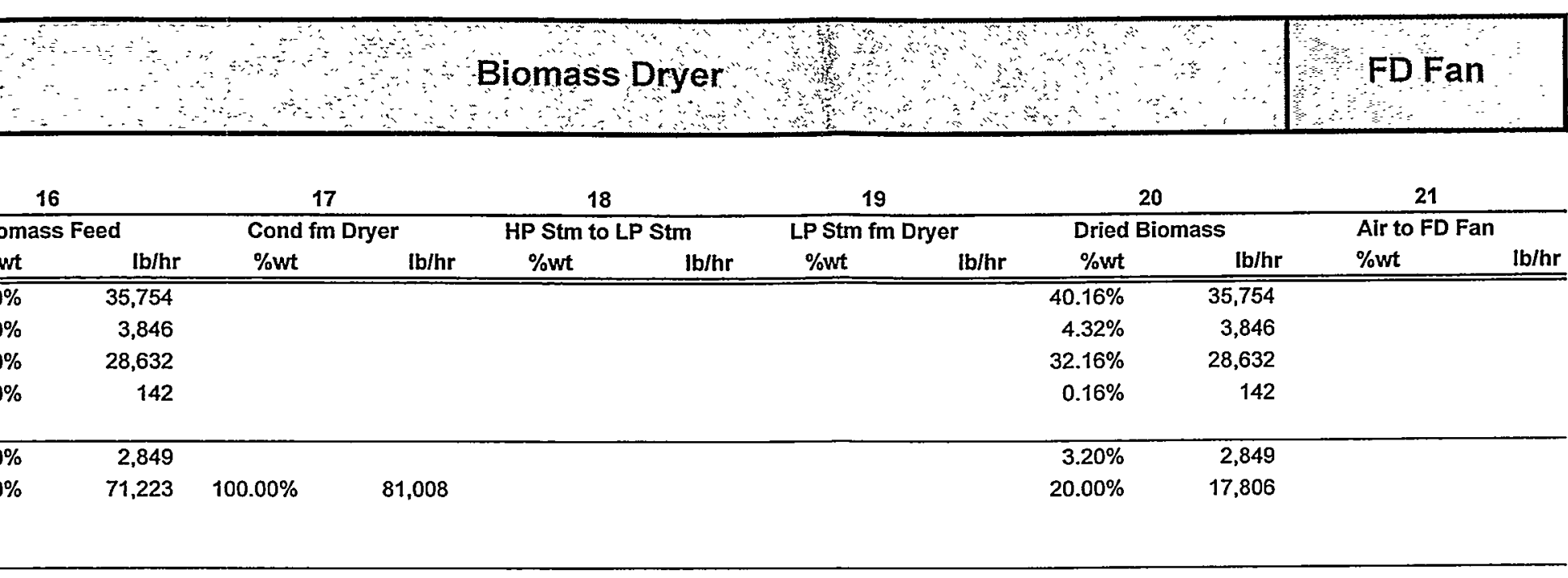

\begin{tabular}{rrrrrr}
$100.00 \%$ & & & & $0.05 \%$ & 86 \\
& 441 & \multirow{2}{*}{53,858} & $0.61 \%$ & 1,047 \\
& & & $23.05 \%$ & 39,562 \\
& & & $76.29 \%$ & 130,940 \\
\hline
\end{tabular}

\begin{tabular}{|c|c|c|c|c|c|c|c|c|c|c|}
\hline 142,446 & $100.00 \%$ & 81,008 & $100.00 \%$ & 441 & $100.00 \%$ & 53,858 & $100.00 \%$ & 89,029 & $100.00 \%$ & 171,635 \\
\hline \multirow[t]{2}{*}{1,709} & & 4,497 & & 24 & & 2,990 & & & & 5,971 \\
\hline & & 18.02 & & 18.02 & & 18.02 & & & & 28.75 \\
\hline 15.70 & & 321.39 & & 54.38 & & 54.38 & & 22.70 & & 14.70 \\
\hline 60.00 & & 413.02 & & 317.66 & & 317.66 & & 213.00 & & 60.00 \\
\hline 15.56 & & 211.68 & & 158.70 & & 158.70 & & 100.56 & & 15.56 \\
\hline \multirow[t]{2}{*}{0.09} & & & & 0.51 & & 62.68 & & 5.93 & & 1.15 \\
\hline & & & & $(0.46)$ & & $(56.43)$ & & & & (1.11) \\
\hline $3,614.22$ & & & & & & & & $6,418.76$ & & \\
\hline $4,400.00$ & & & & & & & & $7,040.00$ & & \\
\hline 514.83 & & & & & & & & 571.45 & & \\
\hline 626.76 & & & & & & & & 626.76 & & \\
\hline 514.92 & & & & 0.05 & & 6.25 & & 577.39 & & 0.04 \\
\hline 626.85 & & & & 0.51 & & 62.68 & & 632.70 & & 1.15 \\
\hline $4,400.65$ & & & & $1,163.83^{\circ}$ & & $1,163.83$ & 66.64 & $7,106.64$ & & 6.70 \\
\hline
\end{tabular}




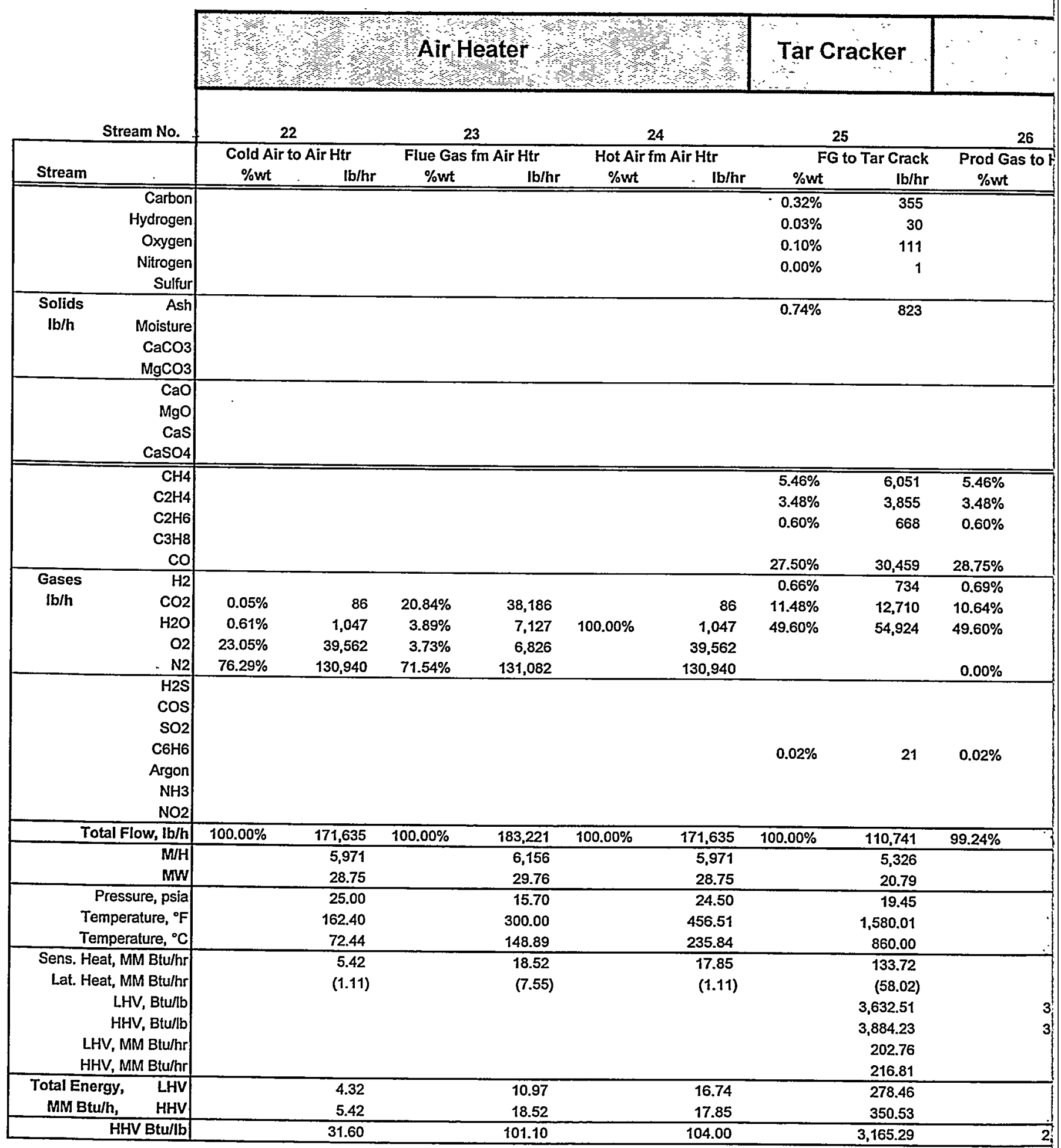


Fuel Gas HRSG

Fuel Gas scrubber

27

\begin{tabular}{|c|c|c|c|c|c|c|c|c|c|c|c|c|}
\hline & \multirow{2}{*}{\multicolumn{2}{|c|}{ BFW to HRSG }} & \multirow{2}{*}{\multicolumn{2}{|c|}{$\frac{28}{\text { SH Stm fm HRSG }}$}} & \multirow{2}{*}{\multicolumn{2}{|c|}{ Prod Gas to Scrubber }} & \multirow{2}{*}{\multicolumn{2}{|c|}{$\frac{30}{\text { Fuel Gas Product }}$}} & \multirow{2}{*}{\multicolumn{2}{|c|}{$\frac{31}{\text { Sludge to Comb }}$}} & \multirow{2}{*}{\multicolumn{2}{|c|}{$\frac{32}{\text { Water to Treatment }}$}} \\
\hline \multirow{2}{*}{$\begin{array}{l}\mathrm{G} \\
\mathrm{Ib} / \mathrm{hr}\end{array}$} & & & & & & & & & & & & \\
\hline & $\%$ wt & $\mathrm{lb} / \mathrm{hr}$ & \%wt & $\mathrm{lb} / \mathrm{hr}$ & $\%$ wt & $\mathrm{lb} / \mathrm{hr}$ & $\% w t$ & $\mathrm{Ib} / \mathrm{hr}$ & $\% w t$ & $\mathrm{lb} / \mathrm{hr}$ & \%wt & $\mathrm{lb} / \mathrm{hr}$ \\
\hline 18 & & & & & $0.02 \%$ & 18 & & & $1.42 \%$ & 18 & & \\
\hline
\end{tabular}

$100.00 \% \quad 55,769$

$0.74 \%$

823

$65.72 \%$

$32.86 \%$

823

411

\begin{tabular}{|c|c|c|c|c|c|c|c|c|c|}
\hline 051 & & & & $5.46 \%$ & 6,051 & $9.92 \%$ & 6,051 & & \\
\hline 855 & & & & $3.48 \%$ & 3,855 & $6.32 \%$ & 3,855 & & \\
\hline 668 & & & & $0.60 \%$ & 668 & $1.10 \%$ & 668 & & \\
\hline 836 & & & & $28.75 \%$ & 31,836 & $52.20 \%$ & 31,836 & & \\
\hline 764 & & & & $0.69 \%$ & 764 & $1.25 \%$ & 764 & & \\
\hline 781 & & & & $10.64 \%$ & 11,781 & $19.32 \%$ & 11,781 & & \\
\hline 924 & & $100.00 \%$ & 55,769 & $49.60 \%$ & 54,924 & $9.86 \%$ & 6,014 & & 48,499 \\
\hline 1 & & & & $0.00 \%$ & 1 & $0.00 \%$ & 1 & & \\
\hline 21 & & & & $0.02 \%$ & 21 & $0.03 \%$ & 21 & & \\
\hline 741 & $100.00 \%$ & $100.00 \%$ & 55,769 & $100.00 \%$ & 110,741 & $100.00 \%$ & 60,990 & $100.00 \%$ & 48,499 \\
\hline 369 & & & 3,096 & & 5,369 & & 2,654 & & 2,692 \\
\hline .63 & 18.02 & & 18.02 & & 20.63 & & 22.98 & & 18.02 \\
\hline .95 & 869.70 & & 864.70 & & 16.45 & & 15.45 & 27.70 & 50.00 \\
\hline .58 & 150.00 & & 950.00 & & 300.00 & & 125.00 & 125.00 & 100.00 \\
\hline .76 & 65.56 & & 510.00 & & 148.89 & & 51.67 & 51.67 & 37.78 \\
\hline .63 & 4.52 & & 76.91 & & 68.42 & & 7.72 & & 51.72 \\
\hline .03) & $(57.59)$ & & $(53.41)$ & & (58.03) & & (6.36) & & $(50.86)$ \\
\hline .17 & & & & & $3,574.95$ & & $6,485.09$ & & \\
\hline .50 & & & & & $3,829.28$ & & $6,946.89$ & & \\
\hline .63 & & & & & 395.90 & & 395.53 & & \\
\hline 82 & & & & & 424.06 & & 423.69 & & \\
\hline .23 & $(53.06)$ & & 23.51 & & 406.29 & & 396.89 & & 0.86 \\
\hline .45 & 4.52 & & 76.91 & & 492.48 & & 431.41 & & 51.72 \\
\hline .16 & 81.12 & & $1,379.13$ & & $4,447.15$ & & $7,073.46$ & & $1,066.35$ \\
\hline
\end{tabular}




\subsection{Significant Findings}

The LIVG technology, when applied in a commercial setting, is a highly integrated process. As such, changes made in one part of the process can have profound effects on other parts of the system that don't appear to have any obvious connection. This section summarizes some of the more significant findings observed during this study.

\subsubsection{Dryer Type}

Two dryer types were examined: a steam dryer and a more conventional rotary dryer that uses hot flue gas as the drying medium. Within each of these types, two alternatives were included.

The steam dryer produces process steam that can be used directly in the gasifier for fluidization. However, if uncontrolled, the amount of steam is governed by the amount of water removed from the biomass feed. Therefore, the more the wood is dried, the more steam is available for the gasifier. It happens that when the wood is dried to $35 \%$ moisture content, the amount of steam produced is very close to the amount required by the dryer. However, if the wood feed is dried beyond $35 \%$, the amount generated by the dryer is in excess of the amount of fluidizing medium needed in the gasifier. Therefore, the use of both an uncontrolled and controlled level of steam flow from the dryer to the gasifier was examined. In the controlled case, the excess steam was condensed with the water going to the plant water treatment facility.

The rotary dryer was also examined under two scenarios. While steam is the medium of choice at the Burlington demonstration facility and was used for the steam dryer option, recycled product gas can also be used. A blower is required to recycle the gas, but this is offset by the elimination of drawing steam from the plant steam system.

An examination of performance, capital cost and environmental impact for these four options revealed that a steam dryer is still the preferred system over the rotary dryer. Between the two steam dryer options, both had almost identical overall efficiency when the usable heat in the product flue gas is accounted for. However, a controlled steam flow requires slightly smaller equipment due to the lower throughput, and, therefore, has a lower capital requirement.

Environmental considerations are also an important factor in choosing a dryer. During the drying, a number of organic compounds are generated. In the case of the steam dryer, these compounds leave with the process steam and are either sent to the gasifier (where they are either destroyed or join the product gas) or they are condensed and sent to the existing waste water treatment facility.

The rotary dryer system is different. The flue gas used in the dryer will contain fine sand particles. These will continue with the flue gas through the dryer where the flue gas will pick up other pollutants that are generated within the dryer. The pollutants expected in the gases exiting the dryer are shown below with their respective sources:

- Total Particulate Matter (PM): wood dust from the dryer with sand and ash from the combustor flue gases 
- Particulate Matter less than 10 microns in aerodynamic diameter (PM-10): wood dust from the dryer with sand and ash from the combustor flue gas

- VOCs: From initial pyrolysis of wood residuals inside the dryer

- Condensable PM: From initial pyrolysis of wood residuals inside the dryer

- NOx : From the combustor flue gas

It is difficult to estimate exactly what level of contaminants will be present, but it appears certain that the level of pollutants will exceed the annual allotment. This means gas cleanup equipment will be required. In addition to the cyclones and multiclones supplied with the dryer, the gas cleaning section includes a Wet Electrostatic Precipitator for particulate control and Regenerative Thermal Oxidizer for reduction of VOCs and condensable PM. This adds both capital and operating cost to the rotary dryer option. It is likely that the plant availability will be reduced, although to what degree was not determined.

\subsubsection{Plant Size}

As part of the current study, Weyerhaeuser prepared data on the projected steam demand by month for the New Bern facility. The results showed that the demand ranged from an equivalent product gas production rate of about $500 \mathrm{M} \mathrm{Btu} / \mathrm{hr}$ in the summer up to about $800 \mathrm{M} \mathrm{Btu} / \mathrm{hr}$ in the winter. It was agreed early in this phase of the study that a single train configuration was desirable to minimize the $\$ /$ Btu capital cost and that the plant size would be set by the large practical size for such a configuration. It was quickly determined that for both types of dryers, a production level of $420 \mathrm{MBtu} / \mathrm{hr}$ of product gas is the maximum level that a single dryer can provide.

The steam dryer is a Niro Size 10 , which is the largest machine currently offered. The Niro dryers come in finite sizes, much as do gas turbines. Therefore, it is not possible to incrementally increase the size of the dryer; and multiple dryers would be required for gas production rates beyond the capability of the Size 10 system. A maximum gas production level of $420 \mathrm{M} \mathrm{Btu} / \mathrm{hr}$ was determined for the Size 10 system based on information provided by Niro during Phase 1.

Although rotary dryers can be made to fit the situation, the $15 \mathrm{ft}$ diameter by $96 \mathrm{ft}$ long dryer suggested by M-E-C is beyond the size of any dryer currently built. They do, however, believe it is a minor extension from existing technology. The majority of dryers offered for large jobs are $13 \mathrm{ft}$ in diameter to allow shop fabrication and overland transportation, although a few $14 \mathrm{ft}$ machines have been built successfully. Having to go to two units for either type of dryer would significantly increase the cost.

It should be noted that the dryer isn't the only equipment that is reaching its size limit. Although it is believed the gasifier and combustor could be sized for much higher flow rates, some consideration would have to be given to using multiples of some of the supporting equipment, such as the cyclone separators. If the system had to be much larger, a double set of cyclones would likely be required to maintain high 
cyclone efficiency and height constraints in the gasifier system. The high-pressure feed blowers are also near the maximum sizes available for this kind of duty.

\subsubsection{Feed Moisture}

Several operating parameters were examined during both phases of the study; however, the impact of feed moisture on the operation and capital cost of the gasifier island for the four systems dominated the current studies. As in Phase 1, the feed moisture was varied from 20 percent moisture up to 35 percent by 5 percent increments. Much of this work was an update of performance evaluations made during Phase 1 . However, the addition of a steam dryer using controlled steam to the gasifier provided a fourth option that turned out to have several benefits.

Before comparing all four systems, it is worth looking at the two steam dryer options and a couple of key variables. Figures 4-4 and 4-5 provide information on the impact of moisture content on the steam flow to the gasifier and sand circulation rates for these two systems. Figure 4-4 shows that almost twice as much steam is sent to the gasifier at the $20 \%$ feed moisture level for the uncontrolled scenario. This extra steam puts a higher heat demand on the gasifier, which means that the gasifier operates at a slightly lower temperature to make more char to provide the extra energy to heat the steam. This increase in heat requirement is reflected in Figure 4-5, which shows the relative sand circulation rates. While the sand circulation is only 10 percent lower when the feed is dried to $20 \%$ moisture, a 10 percent reduction in sand flow will translate to a 10 percent reduction in sand loss and the reduced flow is indicative of the corresponding reduction in size of the equipment in the gasifier system for the controlled steam case.

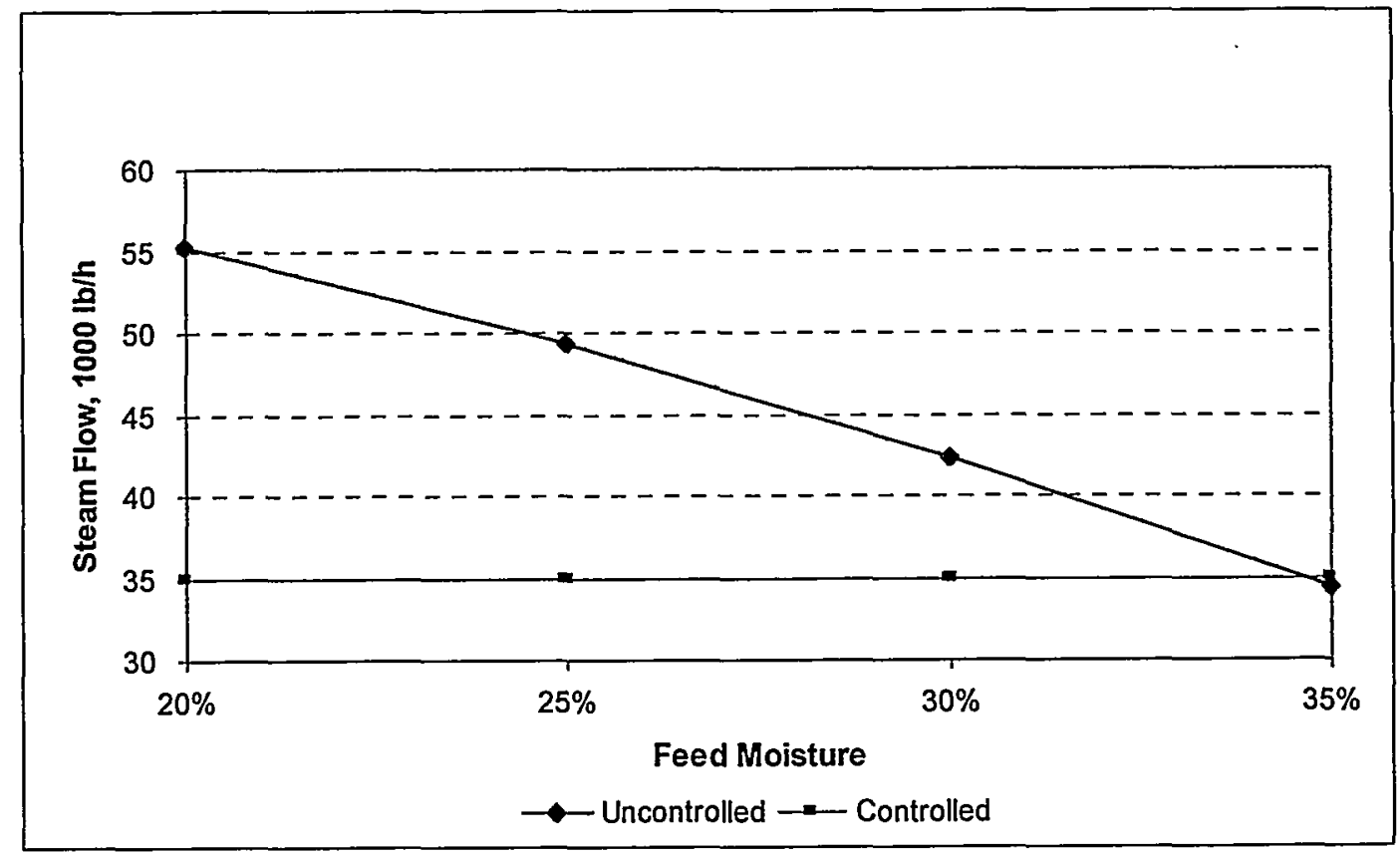

Figure 4-4: Steam to Gasifier 


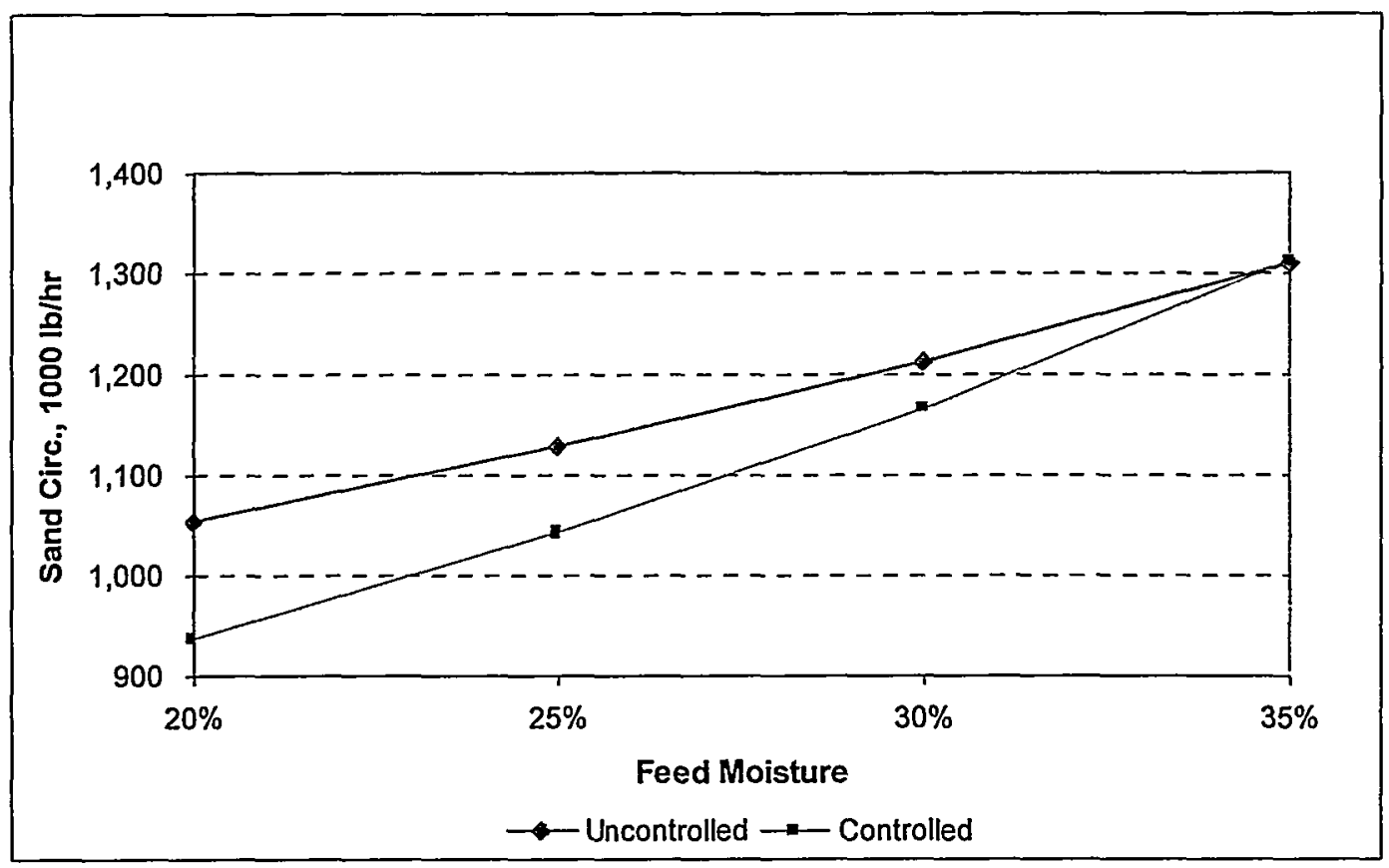

Figure 4-5: Sand Circulation

Figures 4-6 and 4-7 provide a comparison of system efficiency for all four systems evaluated. Figure 4-6 is an update of the cold gas efficiency determinations made during Phase 1 , with the addition of the new steam dryer case. Cold gas efficiency is determined from the fraction of chemical heat available in the wood feed to the gasifier that is transposed to chemical heat in the product gas. It does not account for enthalpy changes or recovery. Figure $4-6$ continues to show that reducing the level of moisture in the feed benefits the cold gas efficiency.

Steam is generated in the Product Gas HRSG, which is added to the plant steam production. Since the product gas will be used for steam generation it makes sense to combine these two sources to determine the true overall efficiency of the gasifier island. Figure 4-7 provides an insight into the overall energy efficiency for the four systems when this extra heat from the Product Gas HRSG is accounted for. The first thing that is noticed is that the degree of change in performance between $20 \%$ and $35 \%$ moisture is much less dramatic. It should be noted that this graph does not account for capital costs that still favor a lower feed moisture. The other thing it shows is that the two steam cases are essentially identical and that both have a considerable advantage over the two rotary dryer cases-especially rotary dryer with steam feed to the gasifier. 


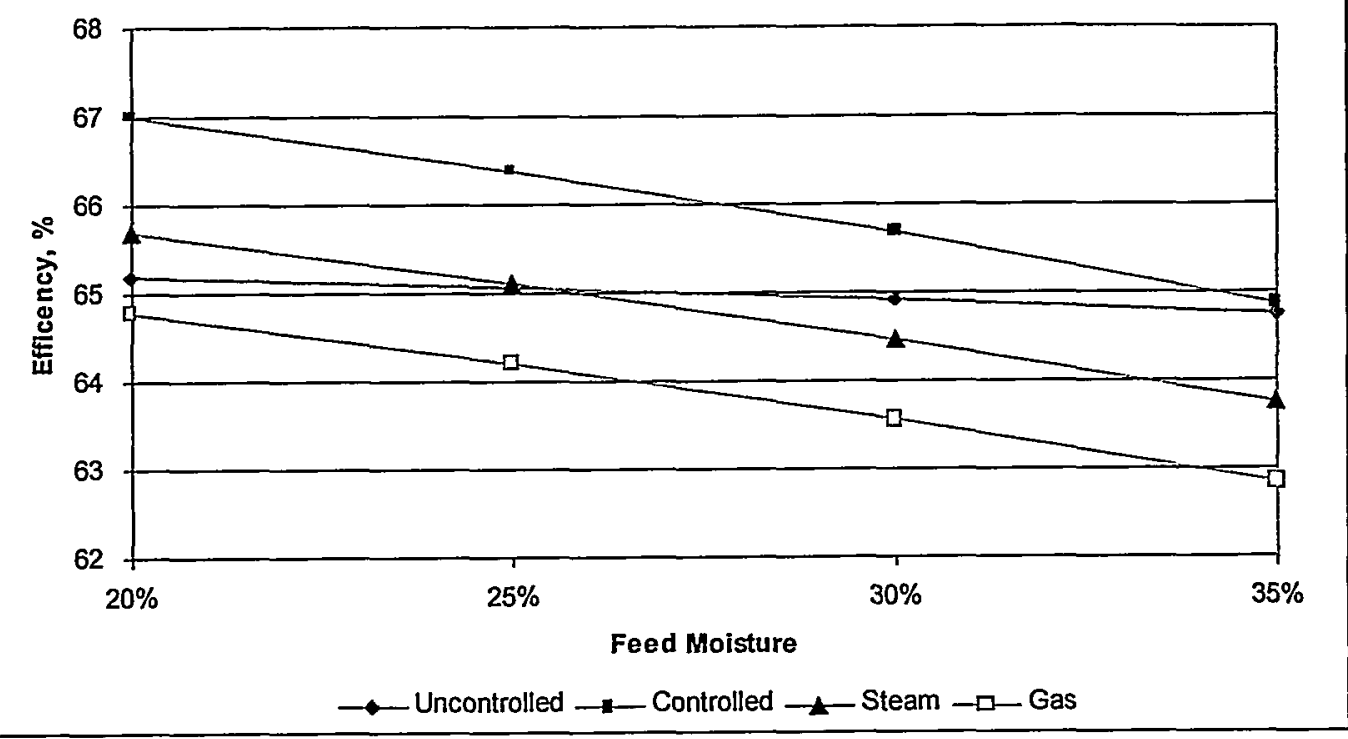

Figure 4-6: Cold Gas Efficiency

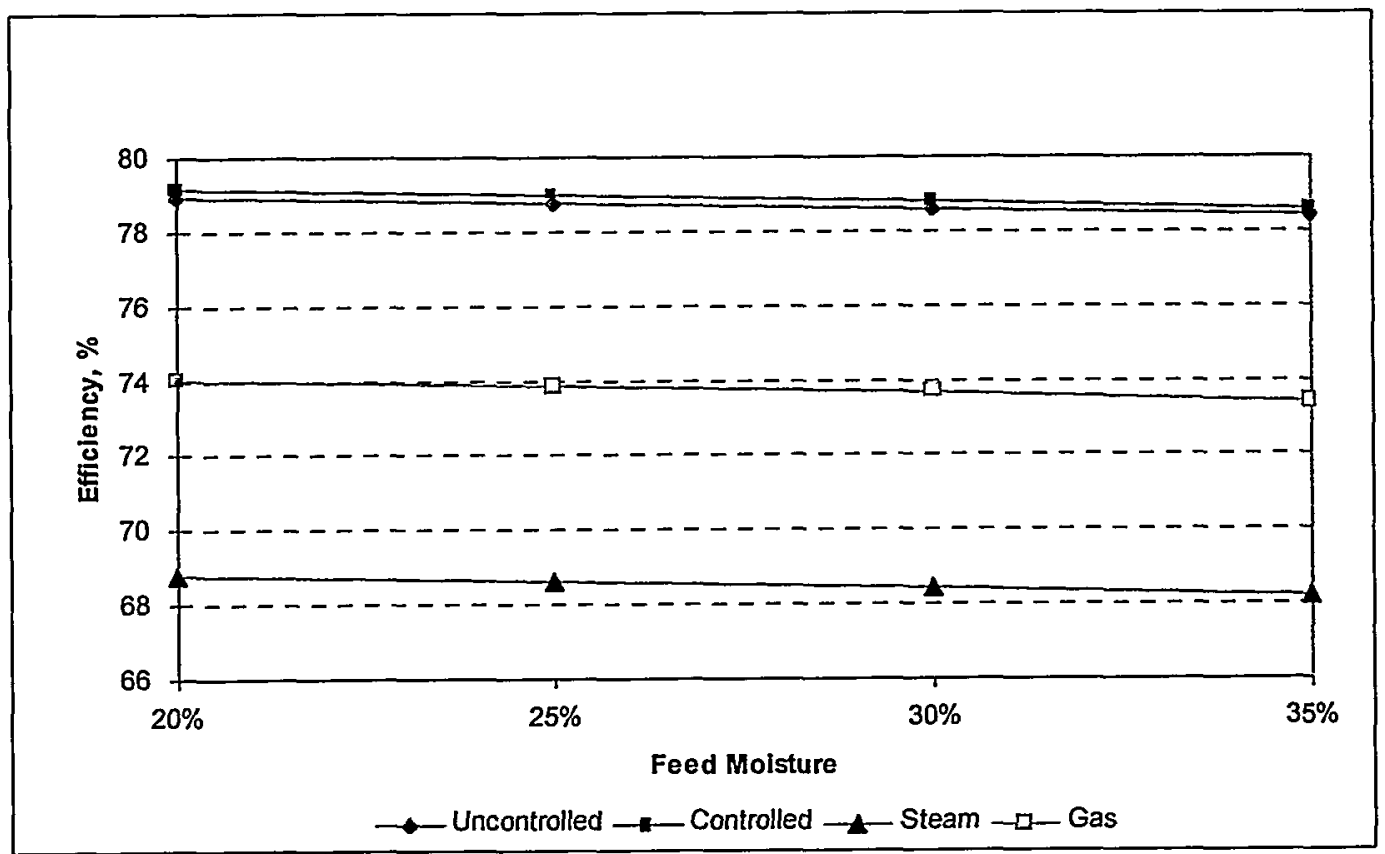

Figure 4-7: Overall Efficiency

\subsection{Implications to Future Designs}

It appears based on the work carried out during Phase 1 and Phase 2 that the steam dryer offers the best match for the LIVG system. The current level of evaluation is as detailed as 
can be made with the available data. If the LIVG process is to be considered further, the following information would have to be available:

- Process data from the Burlington Demonstration Facility including:

- Plant operation parameters while feeding typical New Bern feed compositions

- Confirmation of product gas composition leaving the gasifier

- Tar properties and amounts

- Confirmation of pyrolysis algorithms used in the process models

- Detailed data on the performance and design of the tar cracker

- Detailed information on sand attrition rates and cyclone performance, especially on the gasifier

- Information from the Burlington Demonstration Facility on preferred method and equipment for feeding fuel to the gasifier

- Information from the Burlington Demonstration Facility regarding preferred methods for controlling solids circulation in the gasifier-combustor loop

- Confirmation that the New Bern fuel composition could be handled in the Niro steam dryer

- Confirmation of the steam dryer's capabilities and operating conditions based on testing with New Bern feedstock

Based on details related to the tar cracker, a simplification of the product scrubbing system may be possible. This would reduce both capital and complexity of the current system. A new product cleanup system may also offer opportunities in improving the plant layout, and would certainly reduce the floor space required.

Future designs should provide for additional optimization between the gasifier island and the BOP. Most evident is the determination of the optimum product gas temperature leaving the gasifier island, but there may be some savings or optimization in other areas such as the fuel feed interface and the use and generation of water, steam, and power.

\subsection{Areas of Significant Impact on Economics}

A detailed discussion of capital costs is presented in Sections 4.7, 4.8, and 4.9. This section provides a discussion of how the capital cost and operating costs were impacted by the choices made in the equipment and operating conditions.

\subsubsection{Drying Technology Integration}

Despite the large cost of the dryer system, current work indicated that the actual difference in capital cost between the various dryer cases was minimal, and that most of the gains were in operation, complexity (availability), and environmental aspects. The stream dryer is a much simpler system which integrates extremely well between the dryer and the gasifier/combustor. The combustor provides all the superheated steam required by the dryer and the dryer provides the necessary fluidizing steam for the gasifier. 


\subsubsection{Fluidizing Gas Selection}

Fluidization gas selection is considered to be an application-specific design parameter. The availability of process steam at the conditions required by the gasifier is too opportune to ignore in the current case where a steam dryer is used. However, if pilot testing of the New Bern fuel in the Niro dryer test facility proves disappointing and a rotary dryer has to be used, then it appears that recycling product gas to fluidize the gasifier offers the best option.

An examination of the overall efficiency in Figure 4-7 shows that the efficiency using recycled product gas is more than 5 percent higher. Although the actual plant size would not be significantly different when using product gas vs. steam fluidization, the fact that in the steam case the gasifier would have to draw from the plant steam . system for fluidization steam means that additional oil would have to be used to make up this amount with a corresponding increase in plant operating cost.

\subsubsection{Dryer Product Moisture}

The effect of dryer product moisture was examined again in Phase 2. As discussed in Section 4.4.3, the results gained during the Phase 2 work supported the findings from Phase 1 that the best option is to dry the feed to a $20 \%$ moisture level. Plant performance is maximized and plant capital cost is minimized at the $20 \%$ moisture level. Plant performance is improved because less moisture has to be evaporated in the gasifier. The capital cost is reduced because the savings in the fuel handling, gasifier, and product cleanup systems outweigh the additional capital required for the dryer, which in the steam dryer case is essentially zero.

\subsubsection{Capital and Operating Cost Tradeoffs}

In most plants one weighs spending additional capital to obtain reductions in operating expenses. In this regard, the LIVG process is somewhat unique-at least when looking at the gasifier island as an entity unto itself. In this regard, reducing the feed moisture from $35 \%$ to $20 \%$ reduces both the capital requirements and the operating expenses since the performance is improved, which means less material has to be processed.

A tradeoff study was carried out between the two types of dryers; and as discussed in Section 4.6.1, the difference in capital was not the deciding factor. In this case, the rotary dryer, even with the flue gas cleaning facilities, appeared to be marginally less cost than the steam dryer but the operating cost was higher. However, the overriding issue was the environmental considerations and the added complexity.

\subsection{Capital Cost Estimating Approach}

Two cost estimates for the gasifier island were developed for Phase 2 of the study-an update of the Nth plant cost developed as part of Phase 1, and a modified version of the same estimate that reflects potential costs for a first-of-a-kind, or "next plant" scenario.

The Nth plant costs prepared for Phase 2 reflect local conditions at Weyerhaeuser's New Bern facility. Since the labor rates used for Phase 1 were also developed based on New Bern conditions, this allowed the costs for Phase 2 to be scaled directly from the Phase 1 results. There were two new pieces of equipment in the gasifier island for the new design-a live- 
bottom bin for the dry fuel feed to the gasifier and a steam condenser for the excess steam from the dryer. The equipment cost for the bin was developed using in-house data and verbal quotes from vendors. The condenser costs was scaled from condenser quotes obtained as part of other studies.

The "next plant" cost was developed using methodology used by EPRI. This methodology includes two elements-a reexamination of each major piece of equipment to determine if a change in the equipment size, configuration, or sparing philosophy used for the Nth plant is warranted, and the addition of a process contingency.

Contingency is applied to an estimate to denote the level of confidence in the values ascribed to the finite elements of the particular estimate. The amount of contingency is the estimator's judgment of the cost applied to the complete estimate to yield the most probable total cost or the cost at some specified probability of underrun/overrun. The addition of the contingency value does not improve the overall accuracy of the estimate, but rather reduces the probability of overrun to the desired level. The contingency applied in this study is based on achieving approximately a 50 percent probability of overrun.

Upon further review of previous Bechtel estimates on similar technologies, it was determined that the project contingency for the Nth plant could be reduced from $20 \%$ (used in Phase 1) down to $15 \%$ and still meet this goal. For the "next plant", however, a value of $25 \%$ was considered more in line with past experience.

Process contingency provides an allowance based on process uncertainties or lack of commercial demonstration, i.e., risk. It allows for additional expenditures typically experienced during initial operation, which can include the modification or replacement of equipment not meeting design expectations. An estimate of process contingency is accomplished by examining every subsystem or piece of major equipment in the estimate and assigning a contingency that reflects the level of confidence in the design and operating knowledge of that system. The composite is added as a lump sum to the Total Field Cost along with the Engineering \& Head Office and Project Contingency to give the Total Plant Cost. A weighted process contingency of about $12 \%$ of the Total Field Cost has been estimated and added for the "next plant" scenario. Process contingency is not included for the Nth plant estimate since it is assumed the design has been proven and startup will be routine.

\subsection{Detailed Capital Costs}

A comparison of the revised estimate for Phase 2 and the original estimate for Phase 1 by system is presented in Table 4-6. An examination of the two total columns provides the following information:

- The Total Plant Cost remained essentially the same.

- The combination of higher plant capacity and change of design basis from uncontrolled to controlled steam to the gasifier affected the three main process areas differently.

- The capital requirements for the Fuel Handling area increased by about 7\%. This increase can be attributed to three changes from the original plant: the dry fuel feed bin has been upgraded from a simple cone to a live bottom storage; the conveyor system entering and leaving the bin has been changed to reflect the 
change in bin type; and a process steam condenser has been added to reflect the change in operation to a controlled steam basis.

- Despite the $5 \%$ increase in plant capacity, the cost of the gasification island decreased by a little over $1 \%$ due to the reduced steam injection into the gasifier under the controlled steam flow design.

- Although the tar cracker and scrubber also experienced a slight decrease in cost, cooling the product gas to $125^{\circ} \mathrm{F}$ required a much larger cooler and an increase in the size of the recirculation tanks under the scrubber. The result is a net increase of almost $5 \%$.

The miscellaneous elements, including bulks, were adjusted to reflect to the changes in the major equipment and subsystems.

A capital cost estimate for the first-of-a-kind or "next plant" is presented in Table 4-7. This table also includes in the attached notes, a delineation of the philosophy used in developing the process contingency or equipment modifications made for each line item. Some of the more significant additions include:

- Per Niro's suggestion, an extra $\$ 1$ million has been added to the dryer cost for the first unit.

- A round-robin conveying system has been added to the fuel handling system to reduce the possibility of feed interruptions to the gasifier. The round-robin system allowed the use of a smaller feed bin since it is maintained full.

- The gasifier is provided with two fuel feed systems, also to increase availability.

- A 20\% process contingency has been added for both the gasifier and combustor in case data from Burlington indicates more residence time is required.

- Solids removal from the gas streams is critical so an allowance for secondary cyclones has been added for both the gasifier and combustor systems.

- A 50\% process contingency has been allowed for all ceramic-lined pipe to reflect the limited data available regarding potential erosion issues.

- A 50\% process contingency has also been provided for the tar cracker due to the limited data available.

The overall process contingency is slightly over $12 \%$. When compared to the Nth plant in Table 4-6, the results presented in Table 4-7 indicate the Total Plant Cost for the "next plant" will be $25-30 \%$ higher.

On the surface, these figures appear low based on experience with other projects that show process contingencies in the range of $15-20 \%$ and a Total Capital Cost that is $30-40 \%$ higher for first-of-a-kind plants. However, it should be noted (as it was during Phase 1) that over half of the equipment cost is tied up in four items-the dryer, the two HRSGs, and the air preheater. Although some process contingency has been allowed for each of these items, the level of confidence in these commercially demonstrated systems, is higher than those systems typically associated with demonstration projects, such as the gasifier, combustor and 
tar cracker systems. This heavy weighting of capital in more conventional equipment has lessened the penalty expected with a normal first-of-a-kind project.

\subsection{Capital Cost Result Summary}

The Total Capital Cost of $\$ 36$ million appears to be in line with previous estimates made by Princeton's Dr. Eric Larson, NREL, and others.

One of the original goals set forth by Weyerhaeuser was for Nexant to determine whether significant savings in capital could be gained by improving the design or operation of the gasifier island. Under these guidelines, Nexant has attempted to optimize the design based on the available process data by incorporating a steam dryer (which appears to be uniquely suited to the LIVG process) and by simplifying the equipment where prudent. Nexant has also spent some time studying the effect various operating conditions have on plant performance and the size of the equipment.

As a result of these studies, it is believed that the current combination of using a steam dryer with controlled steam to the gasifier offers the best option for the gasifier island. This is reflected, in part, by the lack of increase in the capital cost despite the $5 \%$ increase in throughput and the addition of some new equipment.

However, none of these improvements has yielded the significant improvement in the capital costs hoped for at the onset of the study. This is largely due to the phenomenon discussed in Section 4.8 that a large percentage of the equipment cost is tied up in items that are less sensitive to changes in gasifier operation. Doubling the capacity of the gasifier-if that were possible - would only offer savings of a few hundred thousand dollars at most, or less than $1 \%$ of the total capital. Conversely, should the current data on the gasifier prove to be optimistic, increasing the size of the gasifier should not have a significant penalty on the Total Plant Cost. The impact on operating economics, however, could be significant.

During Phase 1, several alternate configurations were considered for constructing the gasifier/combustor portion of the LIVG system, including:

- Stacking the major vessels

- Incorporating the cyclones within the major vessels as done for some systems in the petrochemical industry

- Bottom supporting the major vessels instead of top hanging as done at Burlington

Although a detailed examination was not made, a preliminary evaluation indicated that none of these alternatives appeared to offer any advantage over the current configuration. 


\begin{tabular}{|c|c|c|c|c|c|c|}
\hline & Equipment & Bulks & Labor & $\underline{\mathrm{SC}}$ & Total & Phase 1 Total \\
\hline \multicolumn{7}{|l|}{ Fuel Handling } \\
\hline Dryer Feed Screw & 45 & - & 2 & - & 47 & 46 \\
\hline Steam Dryer Assembly & - & - & - & 6,000 & 6,000 & 6,000 \\
\hline Process Steam Condenser & 141 & - & 3 & - & 144 & \\
\hline Transfer Conveyor & 815 & - & 36 & - & 851 & 701 \\
\hline Dried Wood Chip Storage & 480 & - & 81 & - & 561 & 457 \\
\hline Feed Bin & 214 & - & 19 & - & 233 & 21 \\
\hline Rotary Air Lock & 321 & - & 8 & - & 329 & 354 \\
\hline Water Cooled Feed Screw & 51 & - & 3 & - & 54 & 53 \\
\hline Subtotal & & & & & 8,219 & 7,631 \\
\hline \multicolumn{7}{|l|}{ Gasifier/Combustor } \\
\hline Gasifier & 162 & - & 8 & 195 & 365 & 405 \\
\hline Gasifier Hot Gas Line & 58 & - & 8 & 66 & 132 & 149 \\
\hline Gasifier Cyclone & 136 & - & 6 & 242 & 384 & 425 \\
\hline Gasifier Dashpot & 70 & - & 1 & 98 & 169 & 168 \\
\hline Combustor L Valve & 14 & - & 5 & 55 & 74 & 75 \\
\hline Air Blower & 530 & - & 56 & - & 586 & 600 \\
\hline Combustor & 212 & - & 11 & 237 & 460 & 467 \\
\hline Combustor Hot Gas Lines & 103 & - & 13 & 78 & 194 & 198 \\
\hline Combustor Primary Cyclone & 167 & - & 7 & 410 & 584 & 592 \\
\hline Combustor J Valve & 22 & - & 7 & 86 & 115 & 118 \\
\hline Combustor Secondary Cyclone & - & - & - & - & - & 0 \\
\hline Sand Cooler & 10 & - & 1 & - & 11 & 16 \\
\hline Sand Silos & 54 & - & 3 & - & 57 & 53 \\
\hline Magnesium Oxide Storage & 7 & - & - & - & 7 & 21 \\
\hline Expansion Joints & 1,067 & - & 30 & - & 1,097 & 1,111 \\
\hline Misc. Ceramic Pipe & 146 & - & 24 & 601 & 771 & 780 \\
\hline Flue Gas HRSG & 2,062 & - & 14 & - & 2,076 & 1,964 \\
\hline Heat Pipe Air Heater & 659 & - & 25 & - & 684 & 748 \\
\hline Subtotal & & & & & $\overline{7,766}$ & $\overline{7,889}$ \\
\hline \multicolumn{7}{|l|}{ Product Gas Cleanup } \\
\hline Tar Cracker & 118 & - & 6 & 554 & 678 & 755 \\
\hline Product Gas HIRSG & 1,702 & - & 11 & - & 1,713 & 1,742 \\
\hline Venturi & 19 & - & 4 & - & 23 & 24 \\
\hline Scrubber & 193 & - & 13. & - & 206 & 186 \\
\hline Scrubber Cooler & 196 & - & 5 & - & 201 & 34 \\
\hline Skimmer Settling Tank & 71 & - & 9 & - & 80 & 71 \\
\hline Scrubber Recirculation Tank & 64 & - & 3 & - & 67 & 27 \\
\hline Flare & 32 & - & 2 & - & 34 & 37 \\
\hline Subtotal & & & & & $\overline{3,002}$ & $\overline{2,874}$ \\
\hline \multicolumn{7}{|l|}{ Misc } \\
\hline Civil/Structural & - & 1,151 & 556 & - & 1,707 & 1,680 \\
\hline Piping & - & 1,071 & 691 & - & 1,762 & 1,645 \\
\hline Electrical & - & 233 & 78 & - & 311 & 293 \\
\hline Insulation & - & - & - & 158 & 158 & 150 \\
\hline $\mathrm{I} \& \mathrm{C}$ & - & 1,392 & 70 & - & 1,462 & 1,365 \\
\hline Subtotal & & & & & 5,400 & 5,133 \\
\hline Total Direct Cost & & & & & 24,387 & 23,527 \\
\hline Indirects & & & & & 1,728 & 1,613 \\
\hline Total Field Cost & & & & & 26,115 & 25,140 \\
\hline Engr. \& Head Office & & & & & 5,484 & 5,280 \\
\hline Contingency @15\% & & & & & 4,740 & 6,145 \\
\hline Total plant cost & & & & & $\overline{36,339}$ & 36,565 \\
\hline Piping & & & & & 319 & 304 \\
\hline Total plant cost including catalyst & & & & & 36,339 & 36,869 \\
\hline
\end{tabular}

Table 4-6: Total Plant Cost for an Nth Plant (New Bern) by System (January 1999 k\$) 


\begin{tabular}{|c|c|c|c|c|c|}
\hline & Equipment & & Labor & $\underline{\mathrm{SC}}$ & Total \\
\hline \multicolumn{6}{|l|}{ Fuel Handling } \\
\hline Dryer Feed Screw & 45 & - & 2 & - & 47 \\
\hline Steam Dryer Assembly & - & - & - & 7,000 & $7,000^{a}$ \\
\hline Process Steam Condenser & 141 & - & 3 & - & 144 \\
\hline Transfer Conveyors & 1,226 & - & 54 & - & $1,280^{\circ}$ \\
\hline Dried Wood Chip Storage & 480 & - & 81 & - & 561 \\
\hline Feed Bin & 127 & - & 11 & - & $138^{c}$ \\
\hline Rotary Air Lock & 432 & - & 11 & - & $443^{a}$ \\
\hline Water Cooled Feed Screw & 90 & - & 5 & - & $95^{\circ}$ \\
\hline Subtotal & & & & & $\overline{9,708}$ \\
\hline \multicolumn{6}{|l|}{ Gasifier/Combustor } \\
\hline Gasifier & 162 & - & 8 & 195 & $365^{\circ}$ \\
\hline Gasifier Hot Gas Line & 58 & - & 8 & 66 & $132^{\prime}$ \\
\hline Gasifier Cyclone & 136 & - & 6 & 242 & $384^{\mathrm{g}}$ \\
\hline Gasifier Dashpot & 70 & - & 1 & 98 & $169^{\prime}$ \\
\hline Combustor L Valve & 14 & - & 5 & 55 & $74^{\prime}$ \\
\hline Air Blower & 530 & - & 56 & 0 & 586 \\
\hline Combustor & 212 & - & 11 & 237 & $460^{e}$ \\
\hline Combustor Hot Gas Lines & 103 & - & 13 & 78 & $194^{\prime}$ \\
\hline Combustor Primary Cyclone & 167 & - & 7 & 410 & $584^{n}$ \\
\hline Combustor J Valve & 22 & - & 7 & 86 & $115^{\prime}$ \\
\hline Combustor Secondary Cyclone & - & - & - & - & -1 \\
\hline Sand Cooler & - & - & - & - & -1 \\
\hline Sand Silos & 88 & - & 4 & - & $92^{k}$ \\
\hline Magnesium Oxide Storage & 11 & - & 1 & - & $12^{\prime}$ \\
\hline Expansion Joints & 1,067 & - & 30 & - & 1,097 \\
\hline Misc. Ceramic Pipe & 146 & - & 24 & 601 & $771^{\mathrm{m}}$ \\
\hline Flue Gas HRSG & 2,062 & - & 14 & - & $2,076^{n}$ \\
\hline Heat Pipe Air Heater & 659 & - & 25 & - & $684^{n}$ \\
\hline Subtotal & & & & & $\overline{7,795}$ \\
\hline \multicolumn{6}{|l|}{ Product Gas Cleanup } \\
\hline Tar Cracker & 118 & - & 6 & 554 & $678^{\circ}$ \\
\hline Product Gas HRSG & 1,702 & - & 11 & - & $1,713^{P}$ \\
\hline Venturi & 19 & - & 4 & - & $23^{\prime}$ \\
\hline Scrubber & 193 & - & 13 & - & $206^{q}$ \\
\hline Scrubber Cooler & 196 & - & 5 & - & $201^{\prime}$ \\
\hline Skimmer Settling Tank & 71 & - & 9 & - & $80^{q}$ \\
\hline Scrubber Recirculation Tank & 64 & - & 3 & - & $67^{\circ}$ \\
\hline Flare & 32 & - & 2 & - & 34 \\
\hline Subtotal & & & & & $\overline{3,002}$ \\
\hline \multicolumn{6}{|l|}{ Misc } \\
\hline Civil/Structural & - & 1,284 & 620 & - & $1,904^{r}$ \\
\hline Piping & - & 1,192 & 769 & - & 1,961 \\
\hline Electrical & - & 255 & 85 & - & 340 \\
\hline Insulation & - & - & - & 176 & 176 \\
\hline $\mathrm{I} \& \mathrm{C}$ & - & 1,576 & 118 & - & $1,694^{\mathrm{s}}$ \\
\hline Subtotal & & & & & 6,075 \\
\hline Total Direct Cost & . & & & & 26,580 \\
\hline Indirects & & & & & 1,989 \\
\hline Total Field Cost & & & & & 28,569 \\
\hline Engr. \& Head Office & & & & & 5,999 \\
\hline Contingency@25\% & & & & & 8,642 \\
\hline Process Contingency & & & & & 3,550 \\
\hline Total plant cost & & & & & 46,760 \\
\hline Electrical & & & & & 319 \\
\hline Total plant cost including catalyst & & & & & $\overline{47,079}$ \\
\hline
\end{tabular}

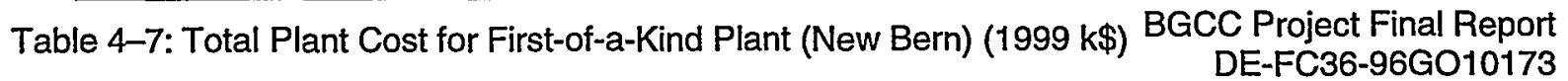
DE-FC36-96GO10173
$\S 4-25$ 
Notes for Table 4-7

Process

Contingency

a) $\quad 10 \%$

b) $\quad 0 \%$

c) $\quad 0 \%$

d) $\quad 0 \%$

e) 205

f) $\quad 50 \%$

g) $\quad 100 \%$

h) $\quad 100 \%$

i)

j)

k)

l)

m)

n)

o) $50 \%$

p) $\quad 15 \%$

q) $\quad 10 \%$

r)

s)

$0 \%$

$50 \%$

$10 \%$

\section{Comments}

Niro suggested a cost of $\$ 700 \mathrm{M}$ for the first plant, in addition, some allowance is given for likely redesign or specification of the flash vessel

Provided for round-robin conveying system

Bin for first-of-a-kind is $1 / 3$ the size since we've added the round-robin conveyor system

Two feed systems provided

Should data from Burlington indicate additional residence time is required

Process Contingency

In case a secondary cyclone is required to further reduce solids to the tar cracker and scrubber

No process contingency is allowed but later more detailed analysis may show a second cyclone to be more cost effective than the enhancements that might be necessary to handle the solids loading in the ESP

0\% Not used, but see note under Primary Cyclone

$0 \% \quad$ Included as part of OBP

0\% Doubled the size of sand silo in the event of higher than predicted sand usage

Doubled the size of $\mathrm{MgO}$ silo in the event of higher than predicted $\mathrm{MgO}$ usage

Process Contingency - This assumes sufficient data is obtained from Burlington to allow for proper design of critical lines, including specification of refractory

To allow for potential rework related either to erosion in unexpected places and/or modifications to solids removal system

Untested design, so final design may be larger or more complex than used here

To allow for potential rework related either to erosion in unexpected places and/or modifications to solids removal system

Process Contingency - This assumes sufficient data is obtained from Burlington to allow for proper design

Additional allowance put in to account for higher structure in case gasifier or combustor become taller

Provided for additional instrumentation plus 50\% additional labor for on-site modifications during startup 


\section{Section 5}

\section{Pulp Mill}

Integration Design \& Cost 


\subsection{Pulp Mill Integration Design \& Cost}

\subsection{Background}

Section 4 dealt with the design and cost of the gasifier island. Its integration with the New Bern pulp mill will be discussed here.

As reported in Section 2, the New Bern pulp mill generates waste wood that is presently sold to a nearby power plant. Prior to 1991, the mill burned the waste wood (hog fuel) along with No. 6 oil in the No. 1 power boiler. Due to emission constraints, this practice was discontinued. The mill currently burns No. 6 fuel oil in its lime kiln, No. 1 power boiler and new No. 2 power boiler.

Two alternatives for returning the mill to biomass fuel were evaluated. The first option is gasification of the mill's hog fuel, sludge and additional wood residuals available from outside sources to produce a medium Btu content fuel gas to totally replace the No. 6 fuel oil. The oil firing capability would be maintained strictly as a backup in the event the gasification system was down for maintenance.

The second option, explained in more detail in Section 7, is to refurbish the No.1 power boiler and add the necessary emission control equipment to allow the unit to once again burn hog fuel. This option would utilize only the mill's hog fuel and would replace a portion of the No. 6 oil usage. The No.1 power boiler was designed to produce about $60 \%$ of its maximum steam generating capacity with wood. To achieve full output, the hog fuel must be supplemented with oil. With this option, the lime kiln and No. 2 power boiler would still utilize oil.

The mill's black liquor recovery boiler and the two power boilers produce steam at $850 \mathrm{psig} /$ $825^{\circ} \mathrm{F}$. The steam is sent to a backpressure/extraction steam turbine generator. Process steam is obtained from a turbine extraction at about $155 \mathrm{psig}$ and from the turbine exhaust at about 55 psig. The steam turbine is capable of generating $29 \mathrm{MW}$ at full load. Since the mill process steam requirements vary with season and also with production, the mill steam generation is constantly adjusted to match the required process steam demand. Less steam generation means reduced throttle steam flow to the turbine generator, which results in less internal electric power generation and increased purchased power. This increases the mill's energy costs. This situation can be rectified by installing a small condensing steam turbine that would allow the mill to produce more electricity during periods of reduced process steam demand. Instead of reducing the steam production of the boilers to meet the process steam needs, the excess steam can be directed to the condensing steam turbine.

Consequently, the installation of a condensing steam turbine, in the $15 \mathrm{MW}$ size range, has been included as part of each of the alternative biomass projects.

\subsection{Integration Design Basis}

The design and capital cost of the gasification system was developed by the Bechtel Corporation and reported in the previous section. Stone \& Webster Engineering Corporation 
prepared the design for the balance-of-plant systems and the condensing steam turbine, and integrated the gasification system cost into a total project capital cost estimate.

The gasification process is designed to convert 73.2 tons $/ \mathrm{h}$ of $50 \%$ moisture feed into $420 \mathrm{MMBtu} / \mathrm{h}$ of fuel gas (HHV basis). The gasification plant design considered here would be located on the current site of the bark storage pile. This pile and the stacking conveyor would be removed to make room for the gasifier installation. Figure 5-1 (Plot plan 07194EM-1A) shows the layout of the Gasification Project.

Annual average ambient air conditions assumed for material balances, thermal efficiencies, and equipment sizing are:

- Dry bulb temperature

- Atmospheric pressure 14.7 psia

Cooling water requirements will be provided by a new cooling tower. $\mathrm{A} 90^{\circ} \mathrm{F}$ cooling water temperature is used for heat exchanger design.

Existing mill instrument air, process water, boiler feedwater, fire protection, and wastewater systems are adequate to support the project. Control of new systems will be incorporated into the existing mill DCS.

The gasification plant terminal points for interconnection to balance-of-plant systems are:

- Dryer feed (wet wood chip) bin outlet

- Dryer start up condenser non-condensables vent pipe to mill high-volume, lowconcentration (HVLC) vent gas collection system

- Dryer start up condenser condensate outlet

- Scrubber product gas outlet

- Combustor heat recovery steam generator (HRSG) ash hopper outlet

- Combustor air heater flue gas outlet

- Scrubber blowdown outlet

- Product gas HRSG steam outlet

- HRSG drum blowdown piping to grade

- Local control (input/output) cabinets

The following utilities are supplied to the gasification plant battery limits:

- Instrument air

- Nitrogen

- High pressure (HP) steam for start up and dryer only operation

- No. 2 fuel oil

- Cooling water supply and return

- Process water

- Fire water

- Boiler feed water make up

- Electric power 
Figure 5-1: Gasification Project Site Plan
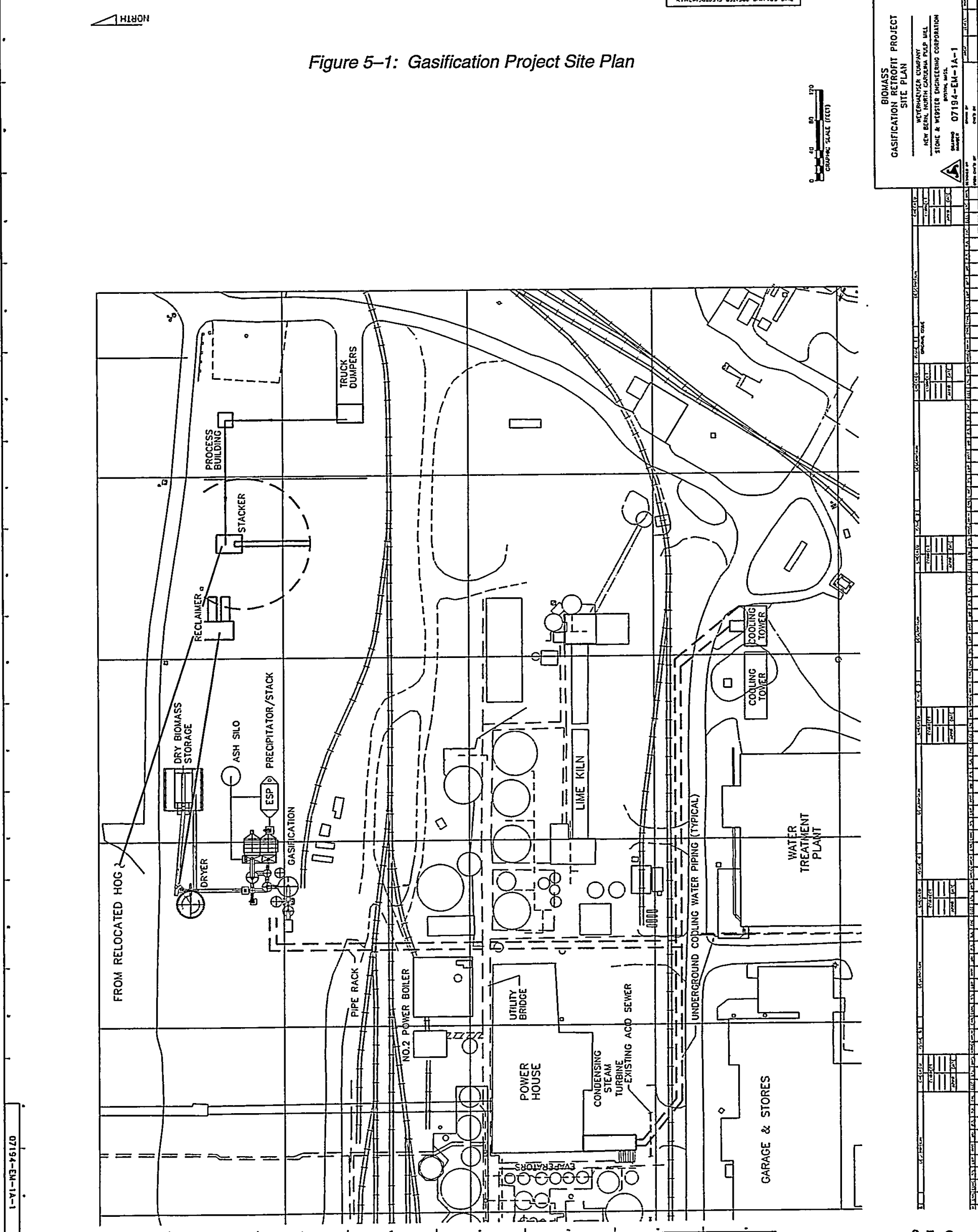

罗圆肾
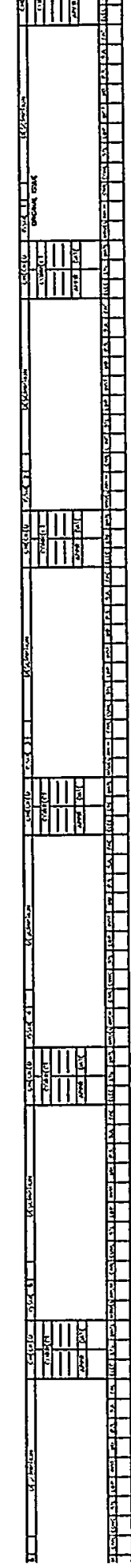


\subsection{Balance of Plant System Descriptions}

\subsubsection{Wood Receiving, Storage and Handling System}

At full capacity, the gasification plant requires 73.2 tons/h of $50 \%$ moisture content wood biomass feedstock. This feedstock is obtained from several sources (see Section 2). The first source-providing approximately 30 tons $/ \mathrm{h}$-is the bark, rejects, sawdust and sludge produced in the mill complex. The other sources include chipped woodlot harvesting and thinning residuals as well as residuals from other wood processing sites in the area. All off-site feedstock is received via 20-ton capacity trucks.

The bark, rejects, sawdust, and associated material produced in the existing mill complex are consolidated in the existing hog fuel processing equipment and flow via a new belt conveyor (W-458) from the existing sizing station to the proposed wet fuel storage pile.

The existing bark sizing station must be relocated to allow proper alignment of the conveyors. This equipment operates two shifts per day (16 hours).

During normal operation, biomass delivery trucks arriving at the facility are weighed on a truck scale (W-451). The trucks then proceed to one of two redundant hydraulic truck dumpers (W-452A, B) which empty the truck contents into an above-grade, live-bottom, $5900 \mathrm{ft}^{3}$ receiving hopper near the gasification plant area. The truck dumpers are designed to tip the trucks, with the trailer still coupled to the cab, into the receiving hoppers. Each of the two redundant dumpers can receive up to seven trucks per hour. With the plant receiving trucks eight hours per day, and an average payload of about 20 tons of chipped biomass, about 130 tons per hour are dumped. Empty trucks return to the scale to obtain their tare weight.

The wood receiving, storage and handling system is shown in Figure 5-2 (PFD-G002).

A belt conveyor (W-453) transfers feedstock from the two receiving hoppers to the process building, as shown in Figure 5-2. In the process building, the material is transferred onto a reversing belt conveyor (W-454). A magnetic tramp metal detection device mounted on this conveyor senses metal contamination in the feedstock, and reverses the conveyor to dump contaminated rejects to the ground. The dumped rejects are periodically removed by a front-end loader and discarded.

The process building contains a disk scalping screen (W-455) and a hammer-type hog (W-456). Material passing through the screen collects on a belt conveyor (W-457) and is transferred to the stacker $(W-460)$. The oversize material that does not pass through the screen is directed to the hog for size reduction. The hog discharges the sized material onto the same belt conveyor for transfer to the stacker.

The sized biomass storage system includes a radial stacker (W-460) that combines the feedstock streams from the process building and from the relocated existing sizing station, and stacks them in a 21-day pile. A bulldozer works the pile on a regular basis to ensure consistent blending of the feedstocks. Material is reclaimed from the 
storage pile by two redundant drag chain conveyors (W-461A, B) via an inlet hopper, which is fed by a bulldozer. The reclaim conveyors feed the material onto the dryer feed belt conveyor (W-464).

The dryer feed belt conveyor discharges the material into an $1800 \mathrm{ft}^{3}$ surge hopper (W-465). Metering screws for feeding the dryer (included in the gasification system scope of supply) will be installed in the bottom of this hopper.

\subsubsection{Equipment List}

Truck Scale (W-451) - Heavy-duty truck scale, fully electronic, including desktop indicator, ticket printer, lightning protection, side rails, truck scale management system, and traffic light signals.

Truck Dumpers (W-452A,B) - Hydraulic truck dumpers. Rated for 35 ton maximum gross weight tractor-trailer trucks, 25 ton maximum payload, and for seven dumping cycles per hour. Each is furnished with above ground $5900 \mathrm{ft}^{3}$ receiving hopper, 160 tph capacity belt-type unloading conveyor, and transfer chute to W-453. Process Building Feed Conveyor (W-453) - Covered, trough-type belt conveyor rated for $160 \mathrm{tph}$; includes $30 \mathrm{HP}$ motor. Conveying distance: $250 \mathrm{ft}$ horizontal, $45 \mathrm{ft}$ vertical. Furnished with steel stringers and support trestles from foundations at grade, and with transfer chute to W-454.

Reversing Conveyor (W-454) - Trough-type belt conveyor with magnetic trampmetal detector. Rated for $160 \mathrm{tph}$; includes $20 \mathrm{HP}$ motor. Furnished with rejects chute and transfer chute to W-455.

Scalping Screen (W-455) - Rated for 160 tph, with sizes as follows:

$$
\begin{array}{rl}
+29 \mathrm{~mm} & 7.9 \% \\
+22 \mathrm{~mm} & 14.6 \% \\
+16 \mathrm{~mm} & 23.0 \% \\
+10 \mathrm{~mm} & 26.3 \% \\
+5 \mathrm{~mm} & 15.9 \% \\
\text { pan } & 12.3 \%
\end{array}
$$

The screen is designed to pass all material smaller than $29 \mathrm{~mm}$. Furnished with $15 \mathrm{HP}$ motor and discharge chutes for oversized and undersized material.

Wet Fuel Hog (W-456) - Hammer-type with 300 HP motor. Rated for 16 tph (10\% of feedstock flow from truck deliveries). Designed to reduce size to $<29 \mathrm{~mm}$.

Wet Fuel Storage Pile Feed Conveyor (W-457) - Covered, trough-type belt conveyor, rated for $160 \mathrm{tph}$; includes $30 \mathrm{HP}$ motor. Conveying distance: $250 \mathrm{ft}$ horizontal; $45 \mathrm{ft}$ vertical. Furnished with steel stringers and support trestles from foundations at grade. Also furnished with loading chute from W-455 and W-456.

Wet Feed Storage Pile Feeder from Existing Hogging Station (W-458) - Covered, trough-type belt conveyor, rated for $50 \mathrm{tph}$; includes $25 \mathrm{HP}$ motor. Conveying distance: $750 \mathrm{ft}$ horizontal; $50 \mathrm{ft}$ vertical. Furnished with steel stringers and support trestles from foundations at grade. Also furnished with discharge chute for transfer of material to W-460. 
Wet Fuel Stacker (W-460) - Rated for $210 \mathrm{tph}$; includes $30 \mathrm{HP}$ motor. Conveying distance: $100 \mathrm{ft}$ horizontal; $30 \mathrm{ft}$ vertical. Furnished with telescoping discharge chute. Wet Fuel Reclaim Drag Chain Conveyors (W-461A,B) - Rated for 75 tph; includes $100 \mathrm{HP}$ motor. Designed to remove material from beneath storage pile and transfer it to W-464. Furnished with inlet hoppers/chutes. Inlet of reclaim conveyor is fed by a bulldozer from the storage pile.

Biomass Dryer Feed Belt Conveyor (W-464) - Covered, trough-type belt conveyor, rated for $75 \mathrm{tph}$; includes $40 \mathrm{HP}$ motor. Conveying distance: $700 \mathrm{ft}$ horizontal; $65 \mathrm{ft}$ vertical. Furnished with loading chute from W-461A, B.

Dryer Feed Surge Hopper (W-465) - $5 \mathrm{ft}$ wide by $18 \mathrm{ft}$ long with an overall height of $20 \mathrm{ft}$. Furnished with inlet hood from W-464. 


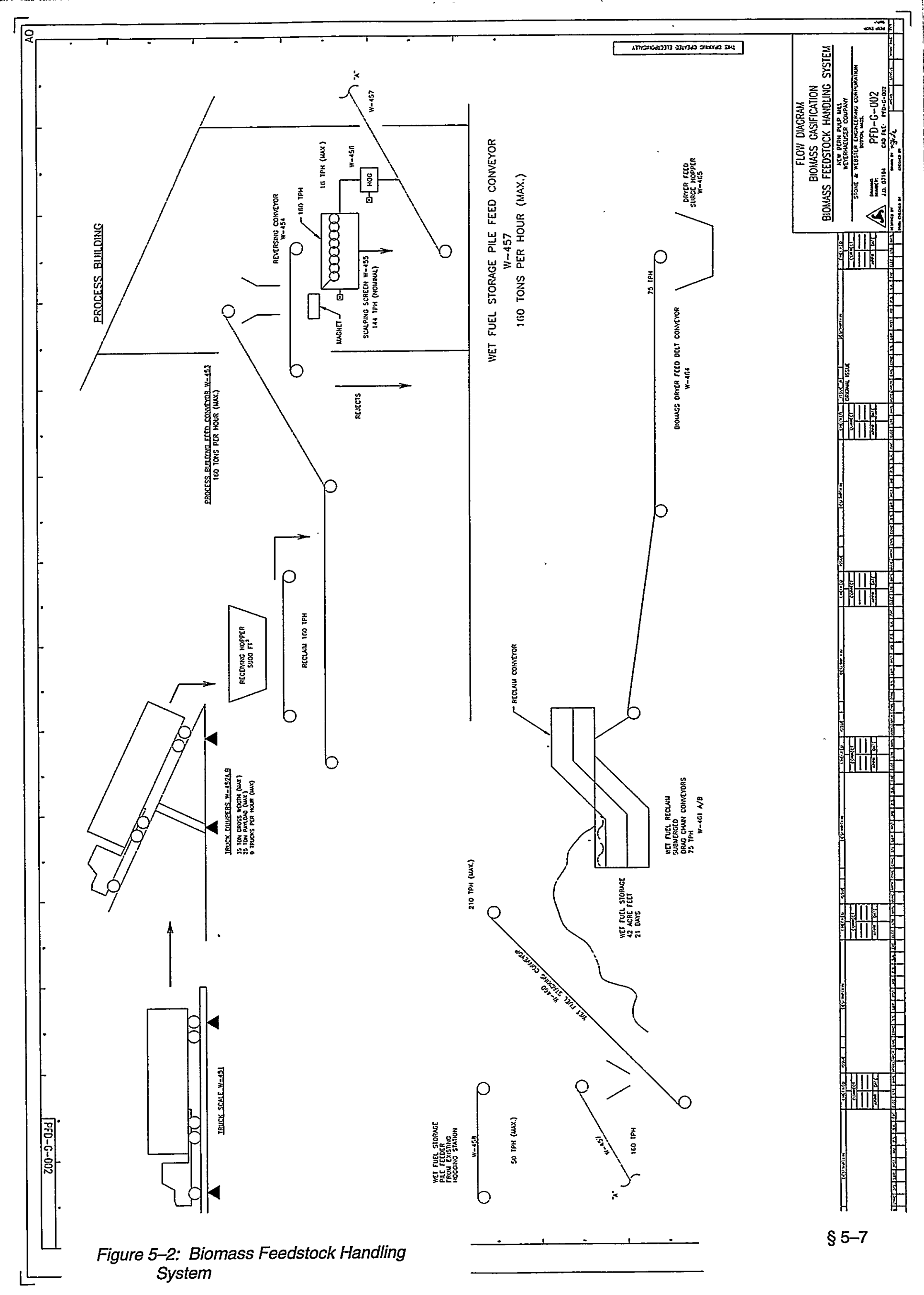




\subsubsection{Ash Collection and Removal System}

The ash leaves the gasification process with the combustor flue gas. This flue gas contains approximately $4,700 \mathrm{lb} / \mathrm{h}$ of biomass ash and sand. It is expected that at least $50 \%$ of this particulate matter (approximately $2,400 \mathrm{lb} / \mathrm{h}$ ) will drop out of the flue gas stream in the combustor HRSG.

Approximately $59,000 \mathrm{acfm}$ of $300^{\circ} \mathrm{F}$ flue gas leaving the air heater passes through an electrostatic precipitator (FGS-ESP1) for removal of the remaining flyash to meet emission standards. The cleaned flue gas will be discharged through a metal stack (FGS-STK1) 150 feet above grade.

The ash collection and removal system is shown in Figure 5-3 (PFD-G-003).

Ash at approximately $800^{\circ} \mathrm{F}$ falls by gravity from the combustor HRSG ash hopper into a water-jacketed screw conveyor (AHS-CNV1) where it is cooled to below $400^{\circ} \mathrm{F}$ with $65 \mathrm{gpm}$ of cooling water. The ash is discharged from the screw conveyor into a double flap airlock (AHS-LK1) to maintain 16.2 psia pressure in the combustor HRSG. The airlock feeds the ash transfer conveyer (AHS-CNV4), a drag chain conveyor that transports the ash to the storage silo (AHS-SILO1).

The ash removed in the electrostatic precipitator collects in two trough hoppers and falls by gravity into two ash collecting conveyors (AHS-CNV2A,B). These dry drag chain conveyors transport the ash to the precipitator transfer conveyor (AHS-CNV3), a dry drag chain conveyor which discharges into a double flap airlock valve (AHSLK2) designed to maintain the 15.7 psia pressure in the precipitator. The airlock directs the ash onto the ash transfer conveyor (AHS-CNV4) where it joins the HRSG ash and is deposited in the storage silo.

The ash storage silo (AHS-SILO1) is sized for 24 hours of maximum gasification process ash production, assuming a minimum ash density of $20 \mathrm{lb} / \mathrm{ft}^{3}$. The actual ash density may be as high as $60 \mathrm{lb} / \mathrm{ft}^{3}$, providing over 3 days of ash storage. The silo is designed to allow a truck to drive under the discharge hopper. The discharge hopper is equipped with an ash conditioning unit (AHS-W1) that wets the ash to increase its density for disposal.

\subsubsection{Equipment List}

Electrostatic Precipitator (FGS-ESP1) - Designed for 64,900 acfm (10\% overdesign) flue gas flow at $300^{\circ} \mathrm{F}$ and 15.7 PSIA with a inlet loading of 8 grains/ACF; Removal efficiency $=99.2 \%$.

Stack (FGS-STK1) - Dual wall steel stack; $150 \mathrm{ft}$ high; $4.5 \mathrm{ft}$ ID Ash Cooling Conveyor (AHS-CNV1) - Design capacity 4 tph; Design pressure 16.2 PSIA; screw type with indirect water cooling; Ash inlet temperature $=800^{\circ} \mathrm{F}$; Ash outlet temperature $=400^{\circ} \mathrm{F}(\max )$; Conveyor overall length $=35 \mathrm{ft} ; 3 \mathrm{HP}$ variable speed motor.

Precipitator Collecting Conveyors (AHS-CNV2A,B) - Design capacity $1.2 \mathrm{tph}$; $2 \times 12$ single strand drag chain with $37 \mathrm{ft}$ horizontal sprocket centers; design pressure $=15.7$ psia; 2 HP motor. 
Precipitator Transfer Conveyor (AHS-CNV3) - Design capacity 2.2 tph; $2 \times 12$ single strand drag chain with $37 \mathrm{ft}$ horizontal sprocket centers; design pressure $=15.7$ psia; 2 HP motor.

Ash Transfer Conveyor (AHS-CNV4) - Design capacity 4.6 tph; 2'-6" wide double strand design with $167 \mathrm{ft}$ true socket centers; horizontal run of $64 \mathrm{ft}+103 \mathrm{ft}$ inclined at $40^{\circ}$ to top of ash silo; $7.5 \mathrm{HP}$ motor.

Double Flap Airlock (AHS-LK1) - Design capacity $=4 \mathrm{tph}$; design pressure $=16.2$ psia

Double Flap Airlock (AHS-LK2) - Design capacity $=2.2 \mathrm{tph}$; design pressure $=$ 15.7 psia

Ash Silo (AHS-SILO1) - Steel silo $26 \mathrm{ft}$ diameter with $60^{\circ}$ bottom cone; $40 \mathrm{ft}$ overall height with bottom outlet $20 \mathrm{ft}$ above grade.

Ash Conditioning Unit (AHS-W1) - Designed for $30 \mathrm{tph}$; maximum ash inlet temperature $=400^{\circ} \mathrm{F}$; includes all valves, fittings feeders from silo bottom outlet through truck loading outlet. 


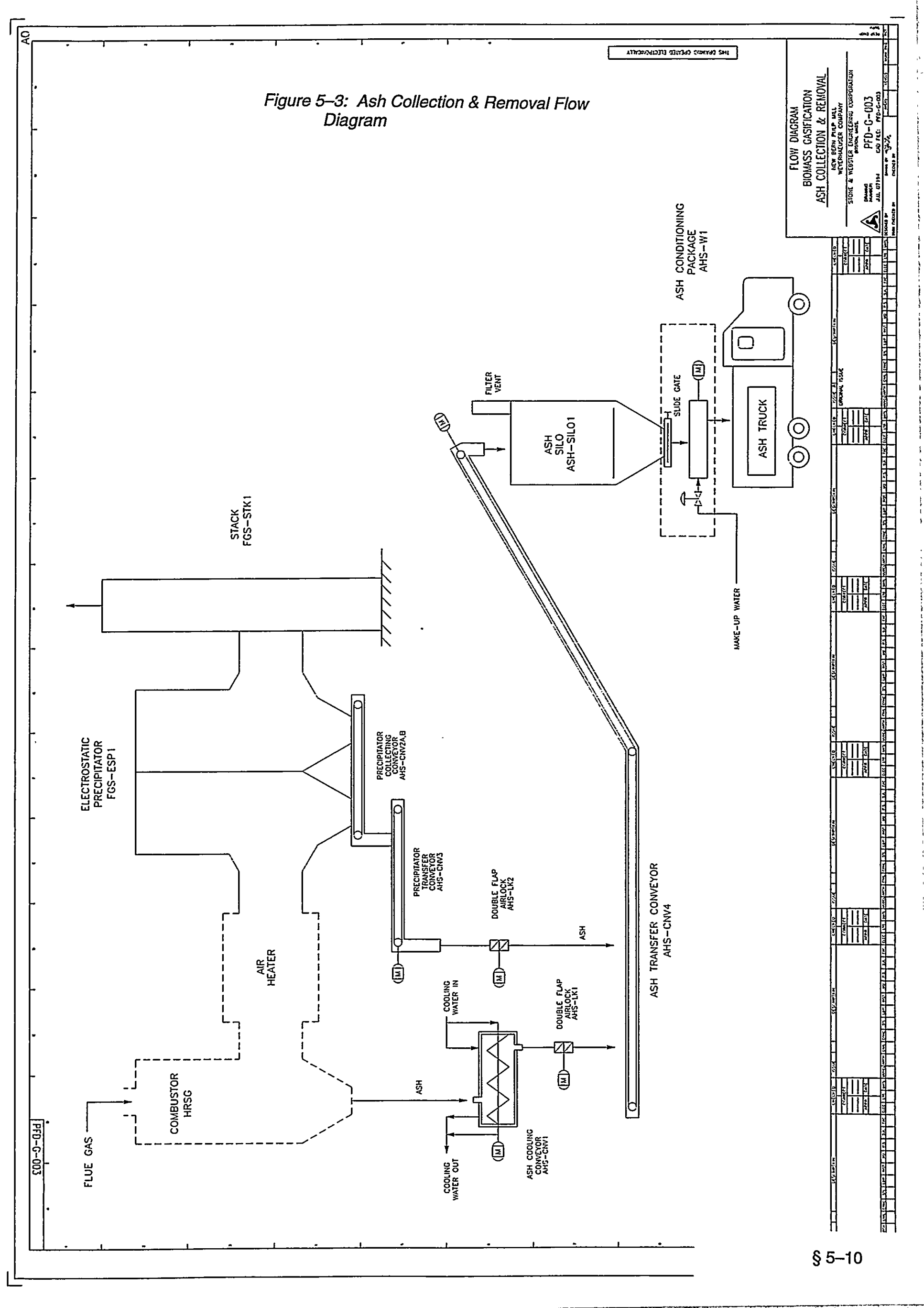




\subsubsection{Product Gas System}

The product gas system receives cleaned product gas from the gasification system scrubber discharge; cools the gas to reduce the water content; compresses the gas; distributes the gas to the mill's No. 1 power boiler, No. 2 power boiler and the lime kiln; and combusts the gas in these units. The product gas system is shown in Figure 5-4 (PFD-G-004).The gasification system produces $60,461 \mathrm{lb} / \mathrm{h}(17,691 \mathrm{acfm}$ at $15.45 \mathrm{psia} / 125^{\circ} \mathrm{F}$ ) of medium Btu heating value fuel gas (MBG). The gas composition is shown in Table 5-1, and the modifications required to utilize the product fuel gas are indicated in Table 5-2.

\begin{tabular}{|c|c|c|}
\hline COMPONENT & VOLUME \% & WEIGHT \% \\
\hline Hydrogen & 14.10 & 1.22 \\
\hline Methane & 14.46 & 10.02 \\
\hline Ethane & 0.85 & 1.04 \\
\hline Ethylene & 5.26 & 6.37 \\
\hline Carbon Monoxide & 41.57 & 50.36 \\
\hline Carbon Dioxide & 11.04 & 21.02 \\
\hline Water Vapor & 12.72 & 9.89 \\
\hline
\end{tabular}

Table 5-1: Product Gas Composition

The gas leaving the scrubber is saturated. The gas is fed to a compressor (PGS-C1) which compresses the product gas to a pressure of $15 \mathrm{psig}$. The compressed gas is distributed via a 12 inch nominal diameter Schedule 20 pipe header to the three product gas users.

\begin{tabular}{|l|l|}
\hline Equipment & \multicolumn{1}{|c|}{ Modifications Required } \\
\hline Lime Kiln & $\begin{array}{l}\text { Change the oil-fired burner to a fuel gas/oil burner with a heat input of } 105 \\
\text { MMBtu/h on either gas or oil. The new burner includes a burner management } \\
\text { system. The existing fuel oil piping train will be retained. } \\
\text { The fuel gas line to the lime kiln is } 8 \text { inch nominal diameter. }\end{array}$ \\
\hline $\begin{array}{l}\text { No. 2 Power } \\
\text { Boiler }\end{array}$ & $\begin{array}{l}\text { Change the multi-fueled (oil, low Btu gas, high concentration low volume vent } \\
\text { gases) dual burner system to a dual fired burner capable of burning these fuels as } \\
\text { well as medium Btu fuel gas(MBG). The MBG capacity of the burner will be } \\
\text { 230 MMBtu/h. The existing fuel oil, low Btu gas, vent gases piping trains will be } \\
\text { retained. The existing burner management system will be expanded to include the } \\
\text { new fuel gas. } \\
\text { The MBG feed line to the No. 2 power boiler is 10 inch nominal diameter }\end{array}$ \\
\hline $\begin{array}{l}\text { No. 1 Power } \\
\text { Boiler }\end{array}$ & $\begin{array}{l}\text { Replace the six existing No. } 6 \text { oil-fired burners with six dual fuel MBG/Oil fired } \\
\text { burners. Each burner has a capacity of } 75 \text { MMBtu/h. The existing Forney burner } \\
\text { management system will be replaced with a new burner management system. } \\
\text { The feed line to the No. 1 power boiler will be 10 inch nominal diameter, reducing } \\
\text { to } 6 \text { inch diameter for each of the six burner valve trains. The existing fuel oil piping } \\
\text { trains will be retained }\end{array}$ \\
\hline
\end{tabular}

Table 5-2: Required Modifications to Utilize Product Gas 


\subsubsection{Equipment List}

Compressor (PGS-C1) - Single stage integrally geared centrifugal compressor package including lube oil system (twin filters, twin pumps, SS downstream of filters), controls (capacity and protection), $1375 \mathrm{HP} 4160 \mathrm{~V}$ motor, dry gas seal, moisture separator, accumulator-receiver.

Lime Kiln Burner (PGS-LKB1) - 105 MMBtu/h dual zone burner burning MBG in the annulus zone and \#6 fuel oil in a center gun including a propane/electric pilot, dual fuel management system, flame scanner and primary air fan.

No. 1 Power Boiler Burners (PGS-PB1B1 through PGS-PB1B6) - Six 650 MMBTU/h dual fuel MBG/\#6 FO burners with main \#6 fuel oil guns, gas spuds, \#2 fuel oil ignitors, fuel valve trains, burner management system and spare main oil guns.

No. 2 Power Boiler Burner Modifications (PGS-PB2B1) - One set of 274 $\mathrm{MMBtu} / \mathrm{h}$ burner gas spuds for retrofit to the existing multifuel burner including MBG valve train and burner management modifications. 


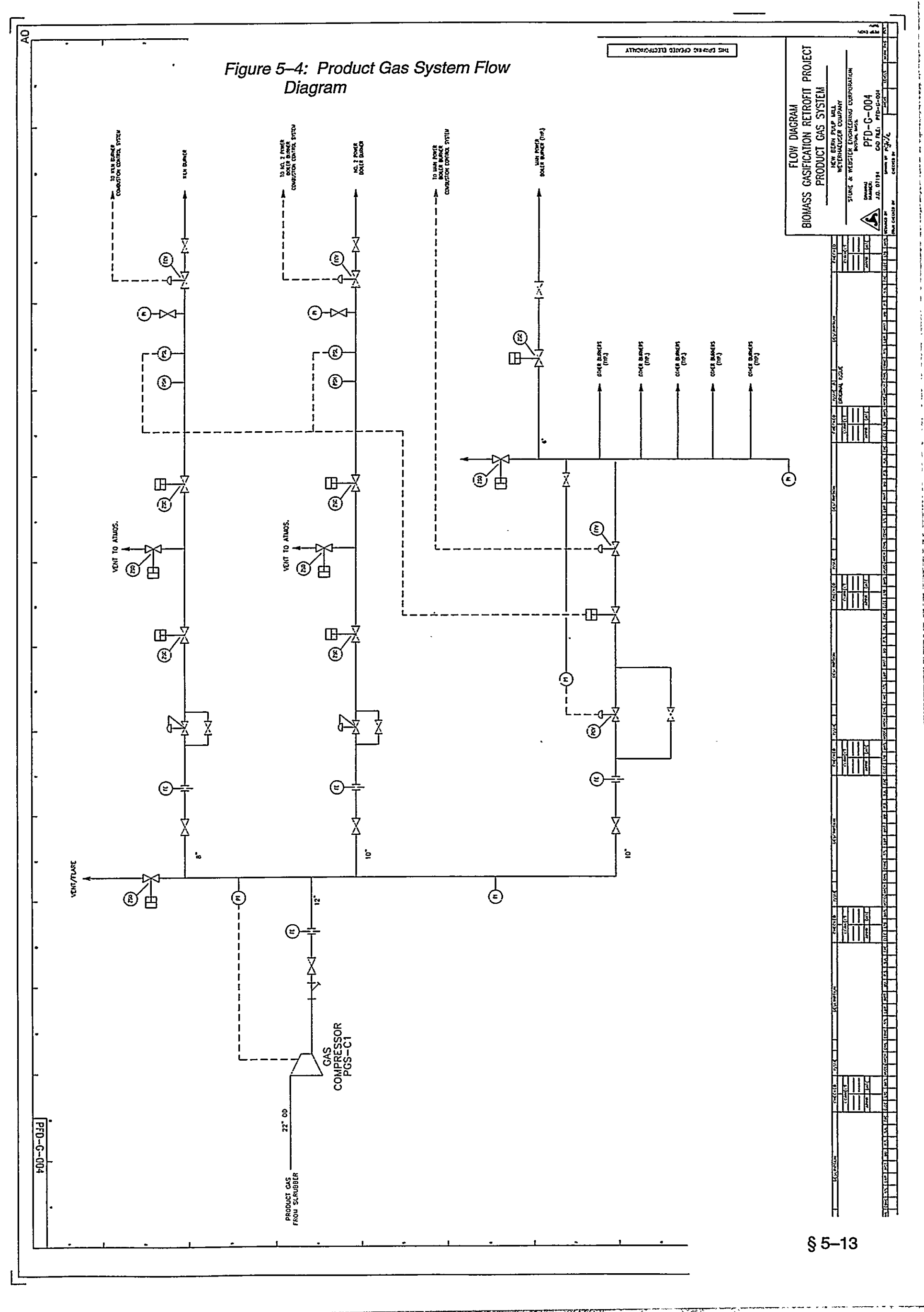




\subsubsection{Condensing Steam Turbine System}

The condensing steam turbine system includes the turbine generator, its control and auxiliary systems, main steam piping from high pressure steam header to the turbine throttle, extraction piping to mill medium pressure and low pressure steam headers, a surface condenser, a condenser air removal system, condensate pumps and condensate piping to existing mill deaerator.

The condensing steam turbine system is shown in Figure 5-5 (PFD-001).

The turbine generator (CST-T1) is a nominal $15 \mathrm{MW}$ machine. Steam is admitted to the throttle at $850 \mathrm{psig} / 825^{\circ} \mathrm{F}$. Steam can be extracted from two stages of the turbine, if desired, to supply the mill's medium pressure (155 psig) and/or low pressure (55 psig) steam headers. The turbine full load exhaust flow with no extractions and a condensing pressure of 3 inches $\mathrm{Hg}$ is $140,000 \mathrm{Ib} / \mathrm{h}$. The extractions are uncontrolled to minimize the turbine cost. Since external controls are employed for the extraction flow and pressure, an exhaust temperature control system is used to ensure that the flow to the exhaust is sufficient to prevent overheating.

The steam exiting the turbine is condensed in a surface condenser (CST-CND1) and the condensate is pumped using one of two $100 \%$ capacity pumps (CST-P1A/B) to the existing mill deaerator. The condenser design duty is $132.5 \mathrm{MMBtu} / \mathrm{h}$. The design cooling water flow rate is $8,823 \mathrm{gpm}$ based on a $30^{\circ} \mathrm{F} \Delta \mathrm{T}$.

Each condensate pump is sized for a maximum flow of $280 \mathrm{gpm}$. Since the condensing steam turbine will normally be operating at partial load, the condensate pump discharge will be recycled to the condenser hotwell as required to maintain a minimum hotwell level. Steam ejectors are used for condenser air removal. The system employs a hogging ejector for start up and a holding ejector for normal operation.

\subsubsection{Equipment List}

Turbine generator (CST-T1) - 15 MW nominal size, with two uncontrolled extractions at 155 psig and 55 psig, exhausting at 3 inches $\mathrm{Hg} ; 13.8 \mathrm{kV}$ totally enclosed water to air-cooled generator.

Surface Condenser (CST-CND1) - Heat transfer surface $=18,319 \mathrm{ft}^{2} ; 5 / 8^{\prime \prime}$ BWG 304 stainless steel tubes; single pressure, 2-pass.

Condensate Pumps (CST-P1A/B) - 280 gpm horizontal centrifugal pump with $30 \mathrm{HP}$ motor 


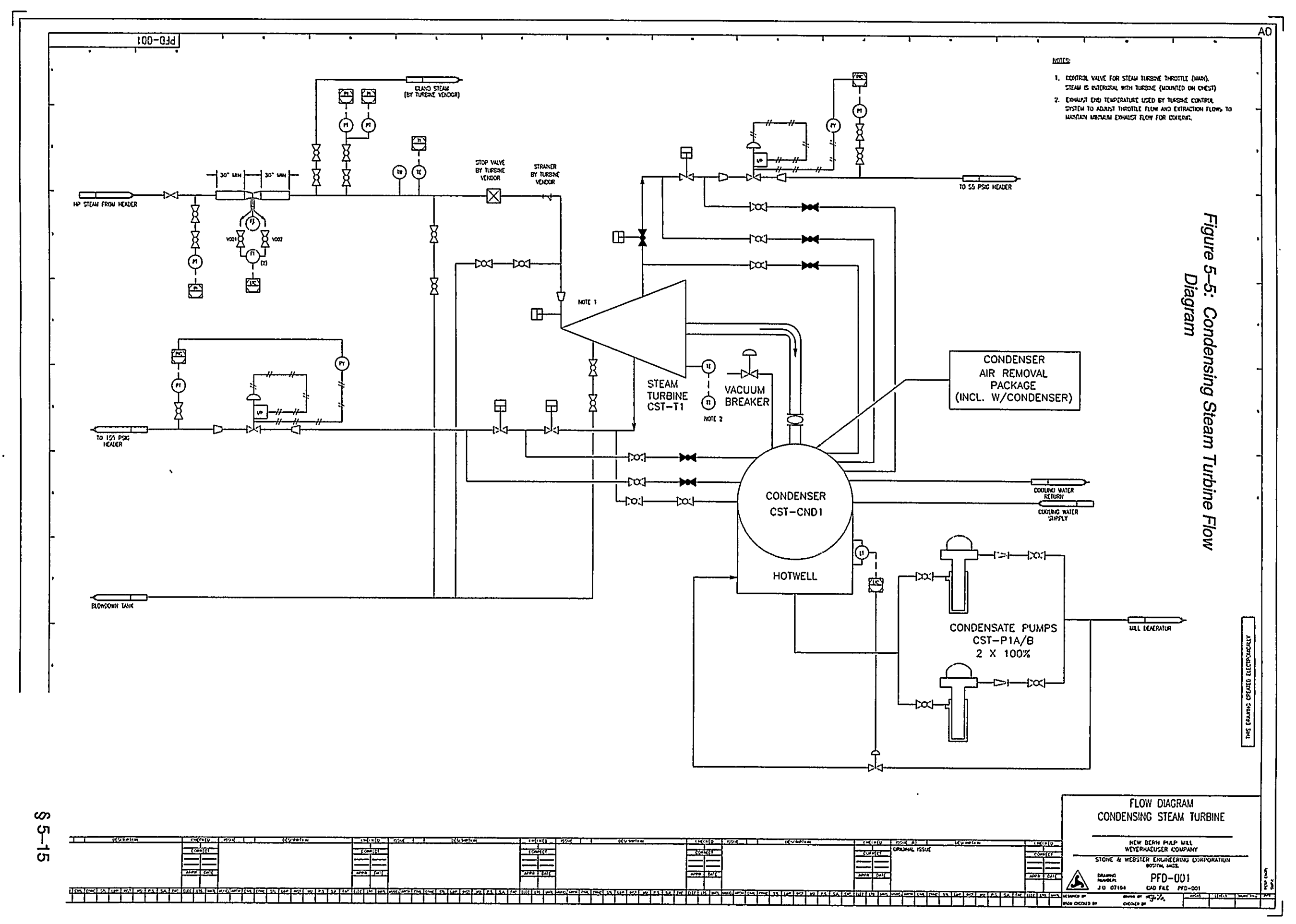




\subsubsection{Cooling Water System}

The cooling water system is shown on Figure 5-6 (PFD-G-005). The system is designed to meet the following cooling requirements:

Product fuel gas scrubber cooler

Product gas compressor lube oil cooler

Gasifier

Condensing steam turbine condenser

Condensing steam turbine lube oil cooler

Condensing steam turbine generator cooler

Combustor ash cooling conveyor

Dryer vent condenser

Nitrogen plant air compressor
6,484 gpm @ $25^{\circ} \Delta \mathrm{T}$

$30 \mathrm{gpm} @ 20^{\circ} \Delta \mathrm{T}$

300 gpm @ $20^{\circ} \Delta \mathrm{T}$

$8,823 \mathrm{gpm} @ 30^{\circ} \Delta \mathrm{T}$

200 gpm @ $20^{\circ} \Delta \mathrm{T}$

$260 \mathrm{gpm} @ 20^{\circ} \Delta \mathrm{T}$

$65 \mathrm{gpm} @ 20^{\circ} \Delta \mathrm{T}$

5,600 gpm @ $20^{\circ} \Delta \mathrm{T}$

$10 \mathrm{gpm} @ 20^{\circ} \Delta \mathrm{T}$

The normal circulating water flow is $16,172 \mathrm{gpm}$ since the dryer vent condenser is only in service if the dryer needs to be operated when the gasification plant is shut down (i.e., to build up inventory of gasifier feedstock).

The system is a closed cycle utilizing a two cell mechanical draft cooling tower (CWS-TWR1). Two 50\% capacity $(8,100 \mathrm{gpm}$ ) circulating water pumps (CWS$\mathrm{P} 1 \mathrm{~A}, \mathrm{~B})$ take suction from the cooling tower basin and distribute the water to the specified users and back to the cooling tower fill. The cooling tower blowdown rate is established to maintain the required water solids levels. The make up water to the tower is controlled by the water level in the basin.

\subsubsection{Equipment List}

Cooling Tower (CWS-TWR1) - Two cell (each cell is $36 \mathrm{ft} \times 36 \mathrm{ft}$ ) counterflow mechanical draft cooling tower with single speed $125 \mathrm{HP}$ fans; tower cooling duty = $223 \mathrm{MMBtu} / \mathrm{h}$

Circulating Water Pumps (CWS-P1A,B) - 8,100 gpm vertical centrifugal pump with $300 \mathrm{HP}$ motor. 


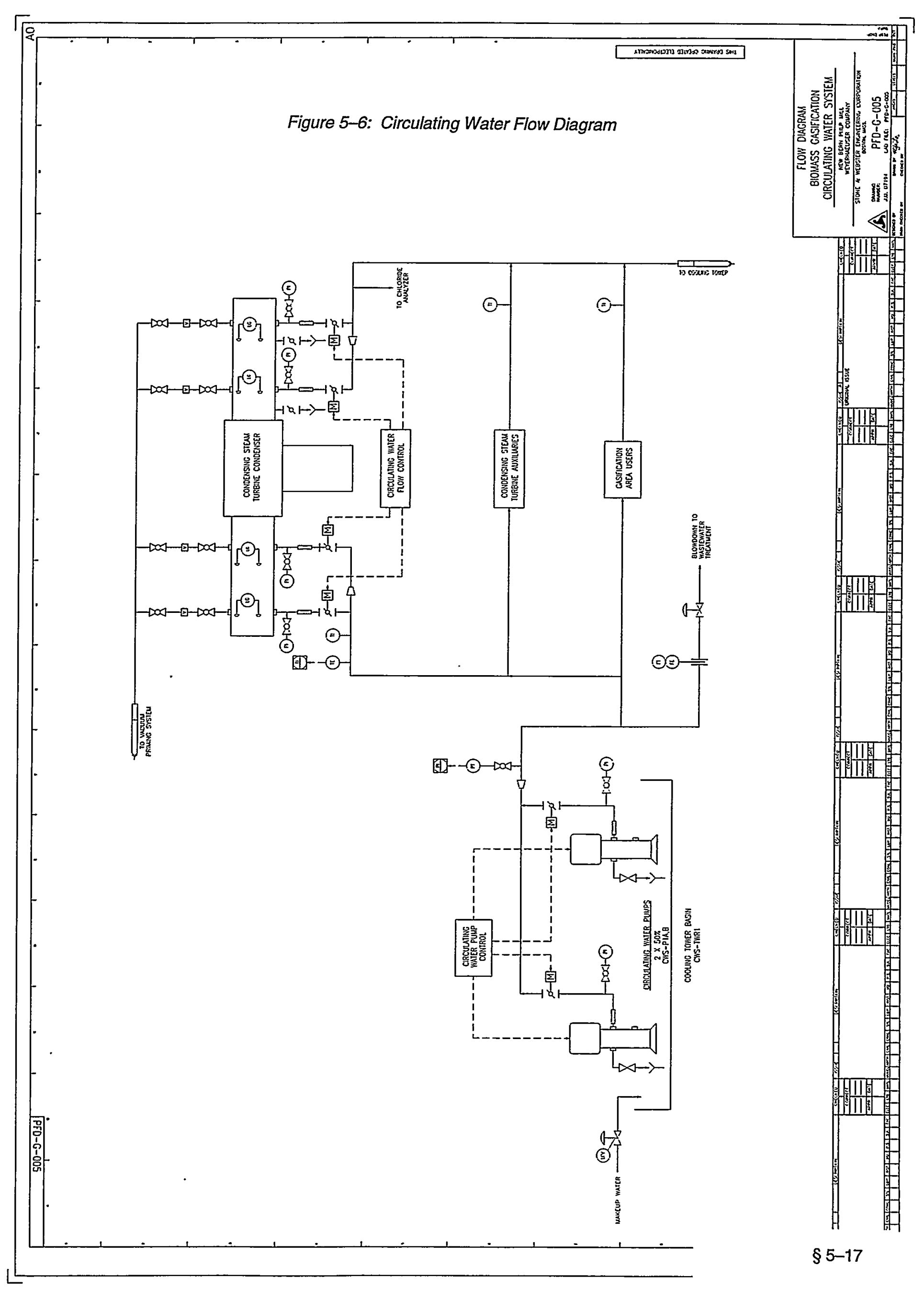




\subsubsection{Other Utility/Infrastructure Requirements}

Extending existing mill utility systems such as process water, compressed air, wastewater and fire protection to the gasification process is straightforward. The most significant integration involves the mill steam generation and distribution system. This system must provide boiler feed water, receive and provide steam and receive steam condensate. The interconnections between this system and the gasification plant are shown in Figure 5-7 (PFD-G-006).

\subsubsection{Nitrogen System}

The gasification system uses up to $75 \mathrm{scfm}$ of nitrogen for continuous inerting/ purging. In addition, 26,900 scf are required for a start up or shutdown. A nitrogen purity of $98 \%$ is acceptable.

A packaged membrane nitrogen generation system is employed. The system is capable of providing up to 5700 normal cubic feet per hour of $98 \%$ purity nitrogen. A $100 \mathrm{HP}$ air compressor supplies air to the membranes. The membranes require 175 psig air. The operating pressure of the system is based on an economic tradeoff between membrane cost and air compressor electricity consumption. The nitrogen leaves the membranes at 150 psig.

For the start up and shutdown purging requirements, a liquid nitrogen storage and vaporization system will be leased. The storage tank holds 6,000 gallons and is 8 feet in diameter by 26 feet high. The system is sized for one start up and shutdown.

\subsubsection{Instrument Air}

The gasification system utilizes $50 \mathrm{scfm}$ of instrument air. The total instrument air requirement for the project is estimated to be less than $75 \mathrm{scfm}$. The existing mill instrument air system has approximately $200 \mathrm{scfm}$ of excess capacity, so a new system is not provided.

\subsubsection{Process Water Make up to Gasification Plant and New Cooling Tower}

The gasification system does not have any continuous requirements for process water. Nonetheless, a connection to the mill's process water distribution system will be provided for intermittent requirements such as the initial filling of the scrubber.

Mill process water is used for cooling tower makeup. The makeup water flow rate to the new cooling tower will be about $567 \mathrm{gpm}$ at full load operation of both the gasification plant and the condensing steam turbine. With the gasification plant at full load and the condensing steam turbine at half load, the cooling tower make up rate would be reduced to about $400 \mathrm{gpm}$. A connection will be provided from the process water distribution system to the cooling tower make up water line.

\subsubsection{Boiler Feedwater Make up to Gasification Plant}

The product gas cooler requires $131 \mathrm{gpm}$ of boiler feed water at $1000 \mathrm{psia}$. The combustor heat recovery steam generator requires $168 \mathrm{gpm}$ of boiler feed water at 475 psia. A high pressure feed water line from the existing mill feed water system will be provided to the gasification plant battery limits. 


\subsubsection{HP Superheated Steam Connection}

The gasification plant requires steam to start up and to operate the dryer to build up dry wood inventory when the gasifier is shut down. During normal operation the gasification system product gas cooler will produce $65,356 \mathrm{lb} / \mathrm{h}$ of high pressure superheated steam.

An interconnection from the existing mill high pressure steam header to the gasification plant is provided to meet these requirements.

\subsubsection{Condensate Return from Gasification Plant to Mill Deaerator}

A condensate return pipe will be provided from the dryer heating steam condensate pump to the mill condensate collection system.

\subsubsection{Blowdown from HRSG Drums}

An atmospheric flash tank is located in the gasification area to receive intermittent and continuous blowdowns from the product gas HRSG steam drum and the combustor HRSG steam drum. The water remaining after flashing will be cooled in a heat exchanger using cooling water and discharged to the mill process sewer.

\subsubsection{Wastewater}

Most of the water in the wood fed to the gasifier is condensed in the product gas scrubber. Approximately $141 \mathrm{gpm}$ of water will be discharged to the mill wastewater treatment system.

When the dryer is operated with the gasification system shut down, the moisture removed from the wood is condensed and sent to the mill wastewater treatment plant. The maximum flow is approximately $111 \mathrm{gpm}$.

The blowdown from the new cooling tower is expected to be between 900 and 1200 gpm, depending upon whether 5 or 4 cycles of concentration is desired. The existing mill wastewater treatment system is capable of handling these additional wastewater loads.

\subsubsection{Vent VOC Collection}

The moisture removed in the dryer will contain volatile organic carbon (VOC) compounds from the wood. This contaminated steam is normally consumed in the gasifier. However, if the dryer is operated while the gasifier is shut down and the water vapor is condensed, the non-condensable gases will contain VOCs that can not be emitted to the atmosphere. The mill has two vent collection systems which utilize vent gases in the No. 2 power boiler. The dryer exhaust condenser vent will be connected to the existing mill HVLC non-condensable gas vent collection system.

\subsubsection{Start Up Fuel}

The gasifier and the combustor require approximately $86 \mathrm{MMBtu} / \mathrm{h}$ of fuel for start up. This requirement will be provided with No. 2 fuel oil (approximately $10 \mathrm{gpm}$ ). A 20,000 gallon tank and forwarding pumps will be located in the gasifier area. 


\subsubsection{Fire Protection}

A fire water line from the existing mill fire loop will be provided to serve the dryer/gasification area.

\subsubsection{Electrical Interconnections}

The generator output from the $15 \mathrm{MW}$ condensing steam turbine will be connected to the mill's $13.8 \mathrm{kV}$ bus. The biomass gasification retrofit project and condensing steam turbine project will utilize between 4.7 and $5.4 \mathrm{MW}$ of electricity on a continuous basis.

A $13.8 \mathrm{kV} / 4160$ volt transformer will be provided to feed a 4160 volt bus to supply electricity to the following major loads which will employ 4160 volt motors:

$\begin{array}{lr}\text { Combustor Blower } & 1,673 \mathrm{~kW} \\ \text { Gasifier Start Up Blower } & 1,431 \mathrm{~kW} \\ \text { Dryer Fan } & 998 \mathrm{~kW} \\ \text { Product Gas Compressor } & 1,044 \mathrm{~kW}\end{array}$

A 4160 volt $/ 480$ volt transformer will be provided to supply a 480 volt load center to service the remaining gasification plant loads including the wood yard, electrostatic precipitator, ash handling and nitrogen systems. These loads are summarized in Table 5-3.

\begin{tabular}{|c|c|c|c|}
\hline . & $\therefore$ & Normal & $\begin{array}{c}\text { Startup } / \\
\text { Shutdown }\end{array}$ \\
\hline Gasification Process & $\begin{array}{l}\text { Combustor Blower } \\
\text { Gasifier Blower } \\
\text { Dryer Fan } \\
\text { Other Dryer } \\
\text { Pumps } \\
\text { Conveyors } \\
\text { Rotary Feeder } \\
\text { Feed Screw } \\
\text { Misc. }\end{array}$ & $\begin{array}{r}\mathrm{kWe} \\
1,673 \\
998 \\
110 \\
59 \\
166 \\
45 \\
7 \\
20\end{array}$ & $\begin{array}{l}\text { kWe } \\
1,431\end{array}$ \\
\hline & $\begin{array}{r}\text { Gasification Subtotal } \\
\end{array}$ & 3,079 & kWe \\
\hline Balance of Plant & $\begin{array}{l}\text { Fuel Gas Compressor } \\
\text { Condensate Pump } \\
\text { Ash Handling } \\
\text { Wood Handling } \\
\text { Nitrogen } \\
\text { Circ Water Pumps } \\
\text { Cooling Tower Fan } \\
\text { Electrostatic Precipitator } \\
\text { Steam Turbine Auxiliaries } \\
\text { Misc. }\end{array}$ & $\begin{array}{r}1,044 \\
18 \\
16 \\
604 \\
75 \\
280 \\
100 \\
46 \\
19 \\
44\end{array}$ & \\
\hline & $\begin{array}{r}\text { BOP Subtotal } \\
\end{array}$ & 2,246 & $\mathrm{kWe}$ \\
\hline & TOTAL & 5,325 & kWe \\
\hline
\end{tabular}

Table 5-3: Gasification Project Electrical Load List 
The condensing steam turbine project loads and the new cooling water system will be connected to the existing mill 480 volt load centers.

\subsubsection{Control System}

The mill has a Rosemount distributed control system (DCS). The system will be expanded to allow control of the gasification plant and condensing steam turbine from the existing mill power and recovery control room. Two operator consoles will be added to the control room. 


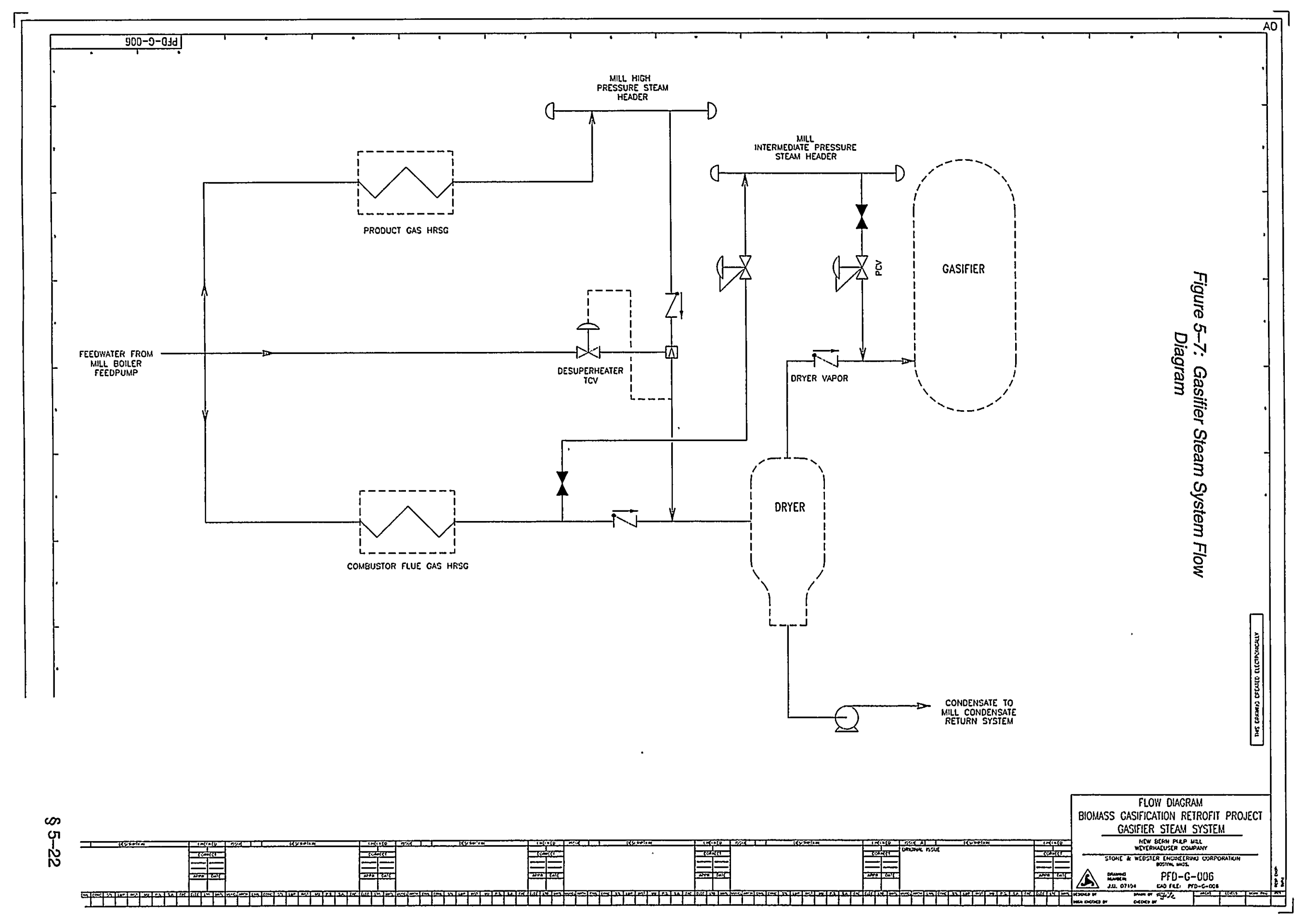




\subsection{Capital Cost Estimates}

Three capital cost estimates were prepared. Two of the estimates are for the gasification retrofit project at the Weyerhaeuser New Bern Pulp Mill and include a condensing steam turbine installation. The first estimate, titled the "Nth Plant Design", represents the cost for a mature gasification technology design. It is based upon expectations for the technology which must be verified. The second estimate, titled the "Next Plant Design", includes the higher costs for the first commercial application of the gasification technology. To provide information for others to evaluate the economics of wood gasification, a third estimate for a generic or non-site specific gasification plant (Nth plant design) was developed.

Bechtel developed the estimates for the gasification process including the dryer. Stone \& Webster prepared the costs for the condensing steam turbine and balance of plant and assembled the complete project estimates.

\subsubsection{Estimating Approach}

The estimating approach and the engineering information provided to support the gasification process estimate are consistent with an Electric Power Research Institute (EPRD) Class II, Preliminary Estimate, as defined in EPRI's Technical Assessment Guide, (EPRI TR-102275-VIR7, Volume 1: Rev. 7, June 1993).

The estimates were developed using flowsheets and site plan/elevation sketches. Process equipment sizes and/or capacity ratings, and fabrication materials/methods were defined. Budget quotes were obtained for major equipment items. Most of the utilities piping outside of the gasification area were sized and estimated based on quantities developed from material takeoffs using the site plan. The rest of the items and bulk materials were estimated using in-house estimating databases. Bechtel checked bulk materials for the gasification system by comparing ratios of bulk material purchase order costs versus major equipment purchase order costs against actual cost ratios from a similar facility - the gasifier and quench units in the Cool Water Coal Gasification Demonstration Project.

These estimates should be characterized as near conceptual, having an accuracy range of $\pm 25-30 \%$.

\subsubsection{Estimating Basis and Assumptions}

The capital cost estimate was developed based on the following assumptions:

- Cost data are based on a January 2000 price level.

- Owners' costs are not included.

- Cost of permits, applications and inspections by governmental bodies not included.

- No clearing and grubbing required.

- No mass earthwork; no allowance for site remediation.

- Excavated material is suitable for structural backfill. 
- Water table is below the lowest level of excavation; no subdrains or special drainage provisions; however, standard curbs and Udrains are provided for the surface facilities and a sump pump for the basement.

- No storm drains. Process area will be graded and paved to direct the runoff to perimeter road gutters.

- Paving is included only for access to ash silo and new wood truck receiving area.

- No material will be disposed of off site.

- There is no provision for sales tax.

- All major foundations rest on precast concrete piles with average length of $60 \mathrm{LF}$.

- A 120 foot long pipe/utility bridge is provided to link the Fuel Dryer and Gasification equipment with the rest of the plant.

- Electrical cables are routed in tray supported from pipe/utility bridge (no underground routing).

- The only underground systems are cooling water to/from the main mill pipe bridge to the condensing steam turbine condenser, electrical grounding and the firewater system.

- No allowance for price/wage escalation has been provided. Project duration would probably be about 24 months.

- Engineering, Procurement, and other management/administration costs ("Home Office Cost") have been estimated as a percentage of the constructed cost of the plant.

\subsubsection{Estimate Components}

\subsubsection{Direct Field Material Costs}

Direct field material costs are for permanent physical plant facilities. They include the following elements:

- Equipment. Equipment includes all machinery used in the completed facility, such as boilers, rotating machinery, heat exchangers, tanks, and vessels.

- Material. Materials include concrete, steel, building materials, pipe and fittings, valves, wire and conduit, instruments, insulation, and paint used in constructing the completed plant.

- Freight. Freight to the jobsite is included.

\subsubsection{Direct Field Labor Costs}

The components of direct field labor costs are labor manhours and the composite labor wage rate.

\subsubsection{Direct Subcontract Costs}

Direct subcontract costs are those for equipment, materials, and services furnished by the subcontractors, including installation labor costs and related indirect field costs. 
Major items that were estimated as subcontract costs include:

- Dryer assembly

- Condensing steam turbine refurbishment and reinstallation

- Cooling tower

- Electrostatic precipitator

- Ash handling equipment

- Refractory

- Insulation, painting, and personnel protection

\subsubsection{Indirect Field and Home Office Engineering Costs}

Indirect field costs are costs that cannot be directly identified with any construction operation related to specific plant facilities but that support the general construction operation.

These costs for indirect labor and materials include allowances for the following items:

- Miscellaneous construction services (labor) covering cleanup, maintenance of tools and construction equipment, security, surveying and testing.

- Temporary construction.

- Materials including temporary buildings and roads, utilities and services, scaffolding, testing, construction equipment, tools and consumables.

- Construction non-manual personnel.

Home office engineering manhours and other home office services cover the expenses of the following items:

- Labor for engineering design, procurement, technical services, administrative support, and project management services

- Office expenses such as materials, telephone, reproduction and computer costs, and travel

\subsubsection{Process Contingency}

A process contingency is not included in the Nth Plant estimate because by definition the Nth Plant represents the mature, proven technology. The Next Plant gasification design is based on a more conservative equipment/system design. Nonetheless, because of the early state of development of the technology, a process contingency is also included in the estimate to provide for modifications that may be required to achieve acceptable performance.

To determine the overall process contingency, Bechtel evaluated the potential uncertainties of each major system/equipment item and assigned a contingency to the total direct cost for each item. The contingencies ranged from $0 \%$ to $100 \%$. The resulting total contingency is $\$ 3,550,000$, which is $13.4 \%$ of the direct cost of the gasification system. The EPRI Technical Assessment Guide suggests that the percentage be between 20 to $35 \%$ for a process for which small pilot scale data is 
available and between 5 to $20 \%$ if there is an operational full-size module. The gasification technology state of development is somewhere in between these two stages. Consequently, a process contingency of $13.4 \%$ is reasonable.

\subsubsection{Project Contingency}

The Weyerhaeuser Standardized Project Process recommends using a project contingency between 8 to $10 \%$. This contingency level is acceptable for small capital cost projects. The EPRI Technical Assessment Guide recommends the project contingency be based upon the level of design/estimating completed. This project meets the definition of a Class II estimate for which a 15 to $30 \%$ project contingency is recommended. A contingency equal to $15 \%$ of the total direct plus indirect cost is applied to the Nth plant estimate. However, for the Next Plant estimate, the project contingency was increased to $25 \%$.

\subsubsection{Nth Plant Design at New Bern Cost Estimate}

The total installed cost for the biomass gasification retrofit project at New Bern based on the Nth Plant Design is $\$ 55.8$ million as shown in Table 5-4.

The Nth Plant Design is a mature design consistent with good engineering practice. The design includes prudent equipment sparing. However, optimum technology performance (not yet demonstrated) is assumed, which would result in minimum equipment sizing.

\subsubsection{Next Plant Design at New Bern Cost Estimate}

The project cost based upon the Next Plant Design is $\$ 67.9$ million as shown in Table 5-5.

The Next Plant Design incorporates conservatism recommended by Bechtel to reduce technical risks. The fuel handling system includes a round-robin conveyor system to move dried fuel continuously from the dryer to the feed bin with overage going on to the dried chip storage bin. A conveyor is provided not just from the storage bin back to the dryer as is used in the Nth Plant Design, but all the way to the feed bin. This provides redundancy in the "S" conveyor moving material to the feed bin. Two feeds with their associated equipment are provided into the gasifier to provide for both redundancy and to ensure proper mixing between the sand and fuel in the bottom of the gasifier. The capacities of the sand and magnesium oxide (MgO) silos are increased in case the sand consumption is higher than expected. A secondary cyclone is added to further reduce solids carryover to the tar cracker and scrubber.

Allowances were included for a taller gasifier/combustor structure, for additional instrumentation and for additional start up support. Finally, a process contingency is added to cover other potential equipment modifications.

The impact of the Nth versus Next gasification plant design on the balance of plant costs is negligible. 


\subsubsection{Generic Nth Plant Gasification Plant Cost Estimate}

The generic gasification plant design is the same capacity as the New Bern design (420 MMBtu/h of fuel gas production), but it does not include the condensing steam turbine project. Specifically, the following modifications were made to the New Bern design to make it generic:

- Condensing steam turbine project was deleted.

- Cooling tower and cooling water pump capacities were reduced to satisfy only the gasification plant cooling requirements.

- Natural gas was assumed to be available for the gasifier start up.

- A totally independent wood receiving, storage and handling system is provided.

- A gasification plant control building is provided.

- The gasification plant battery limits terminate at the fuel gas compressor discharge, i.e., the fuel gas is available at 15 psig pressure, but no distribution/combustion equipment is provided.

The generic gasification plant must still be integrated into an existing steam generation facility (for office/laboratory/sanitary facilities, fire water supply, service water, boiler feedwater, start up steam, a use for the steam produced in the product gas HRSG, wastewater treatment and 4160v/480v electrical supply.

The generic gasification plant capital cost is $\$ 49.9$ million as given in Table 5-6.

\subsection{Operating \& Maintenance Costs}

\subsubsection{Staffing Requirements}

Additional Control Room Operators Wood yard

Truck Unloading

Gasifier Area Roving Operators
1 per shift

1.5 per shift

1 for two shifts weekdays $=2$

1.5 per shift

TOTAL
$=4$

$=6$

$=6$

18 
TABLE 5-4

\section{BIOMASS GASIFICATION RETROFIT PROJECT CAPITAL COST ESTIMATE} NIT PLANT DESIGN

\begin{tabular}{l}
$\begin{array}{c}\text { Basis: January } 2000 \\
\text { Item }\end{array}$ \\
\multicolumn{1}{c}{ PLANT SYSTEMS } \\
Wood Drying/Gasification \\
Gasification Utilities \\
Condensing Steam Turbine \\
Wood Handling \\
Electrostatic Precipitator/ash Handling \\
Product Gas \\
Cooling Water \\
Switchyard/Electrical \\
Distributed Control
\end{tabular}

Subtotal

BULK MATERIALS

Site Improvements

Gasification/Drying

Gasification Utilities

Condensing Steam Turbine

Wood Handling

Ash Handling

Product Gas

Cooling Water

Switchyard/Electrical

Distributed Control

Subtotal

TOTAL DIRECT COST

HOME OFFICE

FIELD NON-MANUAL

TOTAL INDIRECT COST

TOTAL DIRECT \& INDIRECT COST

PROCESS CONTINGENCY

PROJECT CONTINGENCY (15\%)

TOTAL INSTALLED COST

Material

Labor

Subcontract

Total Cost

$$
\begin{array}{r}
9,941,000 \\
250,000 \\
1,678,000 \\
2,315,000 \\
1,504,000 \\
1,615,000 \\
410,000 \\
80,000 \\
270,000
\end{array}
$$

$\$ 18,063,000$

424,000
10,000
350,000
163,000

$\$ 947,000$

$8,622,000$

$\$ 18,987,000$

$\$ 260,000$

$1,280,000 \quad \$ 2,958,000$

$\$ 2,665,000$

$800,000 \quad \$ 2,304,000$

$290,000 \quad \$ 1,905,000$

$\$ 573,000$

$91,000 \quad \$ 171,000$

$75,000 \quad \$ 345,000$

$\$ 11,158,000 \quad \$ 30,168,000$

3,000
$3,847,000$
631,000
195,000
149,000
119,000
165,000
517,000
68,000
20,000

$\$ 5,714,000$

$\$ 23,777,000$

$\$ 3,478,000$

$\begin{array}{rrr}65,000 & & \$ 68,000 \\ 1,395,000 & 158,000 & \$ 5,400,000 \\ 315,000 & & \$ 946,000 \\ 189,000 & & \$ 384,000 \\ 55,000 & & \$ 204,000 \\ 75,000 & & \$ 194,000 \\ 129,000 & & \$ 294,000 \\ 258,000 & & \$ 775,000 \\ 50,000 & & \$ 118,000 \\ & 20,000 & \$ 40,000 \\ \$ 2,531,000 & \$ 178,000 & \$ 8,423,000 \\ & & \\ \$ 3,478,000 & \$ 11,336,000 & \$ 38,591,000\end{array}$

$\$ 7,164,000$

$\$ 2,750,000$

$\$ 9,914,000$

$\$ 48,505,000$

Not Applied

$\$ 7,276,000$

$\$ 55,781,000$ 
TABLE 5-5

\begin{tabular}{|c|c|c|c|c|}
\hline \multicolumn{5}{|c|}{$\begin{array}{l}\text { BIOMASS GASIFICATION RETROFIT PROJECT CAPITAL COST ESTIMATE } \\
\text { NEXT PLANT DESIGN }\end{array}$} \\
\hline \multicolumn{5}{|l|}{ Basis: January 2000} \\
\hline Item & Material & Labor & Subcontract & Total Cost \\
\hline \multicolumn{5}{|l|}{ PLANT SYSTEMS } \\
\hline Wood Drying/Gasification & $10,443,000$ & 440,000 & $9,622,000$ & $\$ 20,505,000$ \\
\hline Gasification Utilities & 250,000 & 10,000 & & $\$ 260,000$ \\
\hline Condensing Steam Turbine & $1,678,000$ & & $1,280,000$ & $\$ 2,958,000$ \\
\hline Wood Handling & $2,315,000$ & 350,000 & & $\$ 2,665,000$ \\
\hline Electrostatic Precipitator/ash Handling & $1,504,000$ & & 800,000 & $\$ 2,304,000$ \\
\hline Product Gas & $1,615,000$ & & 290,000 & $\$ 1,905,000$ \\
\hline Cooling Water & 410,000 & 163,000 & & $\$ 573,000$ \\
\hline Switchyard/Electrical & 80,000 & & 91,000 & $\$ 171,000$ \\
\hline Distributed Control & 270,000 & & 75,000 & $\$ 345,000$ \\
\hline Subtotal & $\$ 18,565,000$ & $\$ 963,000$ & $\$ 12,158,000$ & $\$ 31,686,000$ \\
\hline \multicolumn{5}{|l|}{ BULK MATERIALS } \\
\hline Site Improvements & 3,000 & 65,000 & & $\$ 68,000$ \\
\hline Gasification & $4,307,000$ & $1,592,000$ & 176,000 & $\$ 6,075,000$ \\
\hline Gasification Utilities & 631,000 & 315,000 & & $\$ 946,000$ \\
\hline Condensing Steam Turbine & 195,000 & 189,000 & & $\$ 384,000$ \\
\hline Wood Handling & 149,000 & 55,000 & & $\$ 204,000$ \\
\hline Ash Handling & 119,000 & 75,000 & & $\$ 194,000$ \\
\hline Product Gas & 165,000 & 129,000 & & $\$ 294,000$ \\
\hline Cooling Water & 517,000 & 258,000 & & $\$ 775,000$ \\
\hline Switchyard/Electrical & 68,000 & 50,000 & & $\$ 118,000$ \\
\hline Distributed Control & 20,000 & & 20,000 & $\$ 40,000$ \\
\hline Subtotal & $\$ 6,174,000$ & $\$ 2,728,000$ & $\$ 196,000$ & $\$ 9,098,100$ \\
\hline TOTAL DIRECT COST & $\$ 24,739,000$ & $\$ 3,691,000$ & $\$ 12,354,000$ & $\$ 40,784,000$ \\
\hline HOME OFFICE & & & & $\$ 7,679,000$ \\
\hline FIELD NON-MANUAL & & & & $\$ 3,011,000$ \\
\hline TOTAL INDIRECT COST & & & & $\$ 10,690,000$ \\
\hline TOTAL DIRECT \& INDIRECT COST & & & & $\$ 51,474,000$ \\
\hline PROJECT CONTINGENCY (25\%) & & & & $\$ 12,868,000$ \\
\hline PROCESS CONTINGENCY & & & & $\$ 3,550,000$ \\
\hline TOTAL INSTALLED COST & & & & $\$ 67,892,000$ \\
\hline
\end{tabular}


TABLE 5-6

\section{BIOMASS GASIFICATION RETROFIT PROJECT CAPITAL COST ESTIMATE} NTh PLANT DESIGN GENERIC APPLICATION

Basis: January 2000

Item

Material

Labor

Subcontract Total Cost

\section{PLANT SYSTEMS}

Gasification/Drying

Gasification Utilities

Wood Handling

Ash Handling

Product Gas

Cooling Water

Distributed Control

Subtotal

$$
\begin{array}{rr}
9,941,000 & 424,000 \\
250,000 & 10,000 \\
3,171,000 & 480,000 \\
1,504,000 & \\
700,000 & \\
275,000 & 22,000 \\
295,000 & \\
\$ 16,136,000 & \$ 936,000
\end{array}
$$

\section{BULK MATERIALS}

Site Improvements

Gasification

Gasification Utilities

Wood Handling

Ash Handling

Product Gas

Cooling Water

Electrical

Distributed Control

Subtotal

TOTAL DIRECT COST

HOME OFFICE

FIELD NON-MANUAL

TOTAL INDIRECT COST

TOTAL DIRECT \& INDIRECT COST

PROCESS CONTINGENCY

PROJECT CONTINGENCY (15\%)

TOTAL INSTALLED COST

$$
\begin{array}{rr}
3,000 & 15,000 \\
3,900,000 & 1,437,000 \\
628,000 & 323,000 \\
186,000 & 68,000 \\
119,000 & 75,000 \\
19,000 & 15,000 \\
349,000 & 188,000 \\
25,000 & 25,000 \\
20,000 & \\
\$ 5,249,000 & \$ 2,146,000 \\
& \\
\$ 21,385,000 & \$ 3,082,000
\end{array}
$$

$$
\begin{array}{rr}
8,622,000 & \$ 18,987,000 \\
& \$ 260,000 \\
& \$ 3,651,000 \\
800,000 & \$ 2,304,000 \\
150,000 & \$ 850,000 \\
& \$ 297,000 \\
75,000 & \$ 370,000 \\
\$ 9,647,000 & \$ 26,719,000
\end{array}
$$

$\$ 9,831,000$

$\$ 34,298,000$

$\$ 6,672,000$

$\$ 2,441,000$

$\$ 9,113,000$

$\$ 43,411,000$

Not Applied

$\$ 6,512,000$

$\$ 49,923,000$ 


\section{Section 6}

\section{Syngas Utilization Considerations}




\subsection{Syngas Utilization Considerations}

Medium Calorific Value Gas (MCVG) consists of methane $\left(\mathrm{CH}_{4}\right)$, carbon dioxide $\left(\mathrm{CO}_{2}\right)$, carbon monoxide $(\mathrm{CO})$, hydrogen $\left(\mathrm{H}_{2}\right)$, and water vapor $\left(\mathrm{H}_{2} \mathrm{O}\right)$, along with small amounts of other light hydrocarbons. It has a volumetric heating value approximately half that of typical natural gas, so is potentially a viable industrial fuel. The purpose of this section of the report is to assess the impacts of MCVG on the performance of lime sludge reburning kilns used in the pulp and paper industry as part of the recausticizing operation. In the discussion below, MCVG will be compared to natural gas and to fuel oil, both of which are currently used as fuel for lime reburning in the industry. These fuels will be compared on the basis of flame temperature and other combustion parameters. The results of this comparison will then be discussed in terms of the impact on lime kiln performance. A practical means of assessing MCVG performance with a simple mill trial using fuel oil was proposed, but was not implemented due to the decision to delay consideration of the project at New Bern.

\subsection{Process Impacts Of MCVG}

Table 6-1 lists the approximate chemical composition of several fuels including MCVG, along with a calculation of both the theoretical flame temperature and an estimated actual flame temperature for a lime kiln. The composition of natural gas varies considerably across the country and around the world. The natural gas in the table is an average for natural gas for the Southern U.S. The MCVG (Medium-Btu) is the average of several analysis from the Battelle reports of experiments with the LIVG technology. The chemical composition of the fuel oil is not accurate, but the heating value and stoichiometric air requirement are correct.

Table 6-1 has one column each for natural gas and for MCVG. There are four columns for fuel oil for four different levels of excess air. The calculation of the fuel parameters in the table are based solely on the specified chemical composition and are very straightforward stoichiometric calculations.

The fuel parameters include the very common specification of the volumetric heating value for the gaseous fuels. Pipeline natural gas is typically near $1,000 \mathrm{Btu} / \mathrm{ft}^{3}$. Comparing the heating values shows very dramatic differences between the fuels. However, this common fuel parameter grossly overstates the differences between these fuels. What is often overlooked is the stoichiometric air requirement. It takes both fuel and air to have combustion, so the air requirement is as important as the heating value. The table shows that the air requirement decreases for lower heating value fuels. This is the major reason for the initially surprising result shown for the flame temperatures.

The theoretical flame temperature is a straightforward thermodynamic calculation which accounts for the conversion of all the chemical energy in the fuel into thermal energy in the combustion products. Assumptions are made about the chemical state of the products and about the specific heat of the products, but otherwise the calculation is a strict energy balance. In the table, the combustion products are assumed to be $\mathrm{CO}_{2}, \mathrm{H}_{2} \mathrm{O}, \mathrm{O}_{2}$, and $\mathrm{N}_{2}$; i.e., disassociation of $\mathrm{CO}_{2}$ into $\mathrm{CO}$ and $\mathrm{O}_{2}$ is not included (this is a small effect at these temperatures, and a negligible one at the actual flame temperatures). The specific heat is 
taken for each combustion product as the average for the temperature range from $77^{\circ} \mathrm{F}$ to $3000^{\circ} \mathrm{F}$.

\begin{tabular}{|c|c|c|c|c|c|c|}
\hline & $\begin{array}{c}\text { Natural } \\
\text { Gas }\end{array}$ & $\begin{array}{c}\text { Medium-Btu } \\
\text { Gas }\end{array}$ & Fuel oil & Fuel oil & Fuel oil & Fuel oil \\
\hline \multicolumn{7}{|l|}{ Composition } \\
\hline Methane-CH4 & $83.3 \%$ & $12 \%$ & & & & \\
\hline Ethane-C2H6 & $5.7 \%$ & & & & & \\
\hline Propane-C3H8 & $2.0 \%$ & & & & & \\
\hline Butane-C4H10 & $0.6 \%$ & & & & & \\
\hline Fuel oil equivalent-C10H10 & $0.0 \%$ & $3 \%$ & $100 \%$ & $100 \%$ & $100 \%$ & $100 \%$ \\
\hline Carbon monoxide-CO & & $37 \%$ & & & & \\
\hline Hydrogen-H2 & & $27 \%$ & & & & \\
\hline Nitrogen-N2 & $7.3 \%$ & $3 \%$ & & & & \\
\hline Carbon dioxide-CO2 & $1.0 \%$ & $11 \%$ & & & & \\
\hline Water vapor-H2O & & $7 \%$ & & & & \\
\hline Temperature, ${ }^{\circ} \mathrm{F}$ & 77 & 77 & 250 & 250 & 250 & 250 \\
\hline \multicolumn{7}{|l|}{ Fuel parameters } \\
\hline Higher heating value, Btu/cu ft & 1,007 & 446 & - & - & - & - \\
\hline Higher heating value, Btu/lbm & 20,384 & 7,723 & 19,700 & 19,700 & 19,700 & 19,700 \\
\hline Net heating value, Btu/lbm & 18,423 & 7,128 & 18,973 & 18,973 & 18,973 & 18,973 \\
\hline Air-to-fuel ratio, $l \mathrm{lbm} / \mathrm{lbm}$ & 14.7 & 5.0 & 13.2 & 13.2 & 13.2 & 13.2 \\
\hline \multicolumn{7}{|l|}{ Flame temperatures } \\
\hline Excess air & $10 \%$ & $10 \%$ & $10 \%$ & $20 \%$ & $30 \%$ & $40 \%$ \\
\hline Adiabatic flame temperature, ${ }^{\circ} \mathrm{F}$ & 3,510 & 3,619 & 4,249 & 3,922 & 3,643 & 3,401 \\
\hline Typical flame temperature, ${ }^{\circ} \mathrm{F}$ & 2,873 & 2,914 & 3,117 & 3,019 & 2,923 & 2,829 \\
\hline
\end{tabular}

Table 6-1: Process Impacts of MCVG

Careful examination of Table 6-1 shows that the theoretical flame temperature changes, but the effect is much less dramatic than the heating value would indicate. This is even more true for the estimated actual flame temperature. Here the actual flame temperature calculation takes into account the radiation heat loss from the flame. The conditions used for the calculation are typical of a lime reburning application. The heat input to the kiln was taken as $80 \mathrm{MM} \mathrm{Btu} / \mathrm{hr}$, and the flame was assumed to be 4 feet in diameter and 25 feet long with an emissivity of 0.3 for the gaseous fuels and 0.9 for fuel oil, radiating to the surrounding lime and refractory at $2000^{\circ} \mathrm{F}$. The calculated temperatures are much more realistic estimates of the actual flame temperature in a kiln than the theoretical flame temperature. The differences in this temperature for the various fuels is quite small. This is because the heat in the fuel is absorbed by the combustion products, which consist of the sum of the fuel and the air. A lower air requirement compensates for a lower heating value.

The estimated flame temperature comparison shows several important results. First, the flame temperature for a fuel oil flame at $30 \%$ excess air is almost identical to the flame temperature for the MCVG at $10 \%$ excess air. This means that a practical trial could be carried out in the mill of the impact of MCVG on the kiln by comparing the kiln operation on fuel oil at $10 \%$ excess air (about $1.5 \% \mathrm{O}_{2}$ ) to that at $30 \%$ excess air (about $4 \% \mathrm{O}_{2}$ ). The latter condition would be nearly identical to using MCVG at $10 \%$ excess air. 
The impact of firing MCVG on kiln efficiency will be very modest. A fairly accurate estimate of kiln efficiency can be made from data gathered under normal kiln operation. The required data includes an estimate of production rate based both on mud feed to the kiln and lime required for recausticizing, a kiln shell temperature profile, and operating data such as gas temperature and oxygen concentration in the kiln exit gas, dust loss, etc.

The impact of firing MCVG on the kiln emissions should be modest. The two main emissions from lime reburning kilns are TRS (total reduced sulfur) and particulate. MCVG combustion characteristics will be very similar to those for natural gas and fuel oil. Complete combustion of fuel and incineration of NCG (non-condensable gases) depends primarily on having sufficient oxygen and good gas mixing in the kiln. At the same flue gas $\mathrm{O}_{2}$ level, natural gas, fuel oil and MCVG should produce the same destruction efficiency for NCG, with a resulting equivalent flue gas TRS level. Combustion conditions for these fuels will not impact TRS from $\mathrm{Na}_{2} \mathrm{~S}$ in the lime mud to any significant degree. The quantity of particulate loss from the stack depends on both the dust loss from the kiln and the scrubber efficiency. The impact of MCVG can be assessed using the trial with fuel oil at two different excess air levels. 


\section{Section 7}

\section{Power Boiler Relifing as a Conventional Alternative}

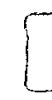

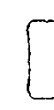

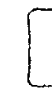

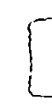

I

I 


\subsection{Power Boiler Relifing as a Conventional Alternative}

\subsection{Background}

The previous two sections dealt with the integration of a gasification system into the New Bern mill and the use of the synthesis gas produced. The present section considers a relifing of the existing No. 1 power boiler to burn wood residuals as the preferred conventional technology alternative for the mill.

In 1991, CRS Sirrine Engineers Inc. developed a design for refurbishing the No.1 power boiler at New Bern. The boiler was originally installed in 1967; and its condition had deteriorated, impacting its reliability. The boiler was still firing hog fuel at that time, but the sand scrubber that Weyerhaeuser had installed to reduce particulate emissions was not operating satisfactorily. Sirrine's scope included replacing the sand scrubber with an electrostatic precipitator to meet emission requirements and making other upgrades necessary to allow the unit to provide good performance for another 15 years. Sirrine prepared a detailed design in order to meet Weyerhaeuser's requirement for a Class $10( \pm 10 \%)$ cost estimate. The Sirrine design was not implemented. Weyerhaeuser and Jacobs-Sirrine updated the design and estimate in 1994. Rather than upgrade the No. 1 power boiler, Weyerhaeuser decided to eliminate burning hog fuel and reduce its service requirements by adding a smaller oil-fired boiler.

For the present evaluation, Stone \& Webster utilized the detailed design information from Sirrine and added the necessary design for reactivating the hog fuel handling and feed system and installing the condensing steam turbine with its associated utility/balance of plant systems.

\subsection{Design Basis}

The No. 1 power boiler was designed to produce up to $388,000 \mathrm{lb} / \mathrm{h}$ of $850 \mathrm{psig} / 825^{\circ} \mathrm{F}$ steam when firing oil and up to $350,000 \mathrm{lb} /$ hour of steam when firing $30 \mathrm{ton} / \mathrm{h}$ of hog fuel $(50 \%$ moisture) and 1,568 gallons/hour of oil. Since the mill has installed the No. 2 power boiler, the No. 1 power boiler loading has been significantly reduced. Consequently, the relifing project is based on a maximum steam generation capability of $300,000 \mathrm{lb} / \mathrm{h}$ with either oil only or oil/wood firing.

The expected performance of the relifed boiler is detailed in Table 7-1. 


\begin{tabular}{|c|c|c|c|}
\hline & OLL ONLY & HOG EUEL+OIL & HOG FUEL,ONLY \\
\hline $\begin{array}{c}\text { MAX. STEAM } \\
\text { GENERATION, Ib/h }\end{array}$ & 350,000 & 300,000 & 171,300 \\
\hline Boiler Efficiency, \% & 86.127 & 76.92 & 71.47 \\
\hline $\begin{array}{c}\text { Oil Heat Input (HHV } \\
\text { Basis), MMBtu/h }\end{array}$ & 457.8 & 169 & NA \\
\hline $\begin{array}{c}\text { Hog Fuel Heat Input } \\
\text { (HHV Basis), MMBtu/h }\end{array}$ & NA & 270 & 270 \\
\hline Oil Feed Rate, lb/h & 24,746 & 9,135 & NA \\
\hline Oil Feed Rate, gpm & 51.2 & 18.9 & NA \\
\hline Hog Fuel Feed Rate, lb/h & NA & 60,000 & 60,000 \\
\hline
\end{tabular}

Table 7-1: Relifed Boiler Expected Performance

At $300,000 \mathrm{lb} / \mathrm{h}$ steam production, the total heat input to the boiler is $439.35 \mathrm{MMBtu} / \mathrm{hour}$. The $30 \mathrm{tph}$ of hog fuel contributes $270 \mathrm{MMBtu} / \mathrm{h}$ and 1,116 gallons/h of No. 6 fuel oil provides the remaining 169.35 MMBtu/h of heat input.

Performance at reduced loads are predicted to be:

\begin{tabular}{|c|c|c|c|}
\hline & & LOAB $\mathbf{k p p h}$ & : \\
\hline & 50 & 150 & 300 \\
\hline FUEL & \multicolumn{3}{|c|}{ Boiler Efficiency, \% } \\
\hline Oil & 85.29 & 86.37 & 87.46 \\
\hline Wood & 69.02 & 73.33 & N.A. \\
\hline \multirow[t]{2}{*}{ Wood \& Oil } & 75.03 & 75.57 & 76.92 \\
\hline & \multicolumn{3}{|c|}{ Performance } \\
\hline Excess Air, \% & 100 & 50 & 15 \\
\hline Steam Temp., ${ }^{\circ} \mathrm{F}$ & 700 & 825 & 825 \\
\hline Exit Gas Temp., ${ }^{\circ} \mathrm{F}$ & 270 & 300 & 320 \\
\hline $\begin{array}{c}\text { Unburned } \\
\text { Combustibles Heat } \\
\text { Loss, \% }\end{array}$ & $\begin{array}{c}\text { Oil }-0 \% \\
\text { Wood }-2 \%\end{array}$ & $\begin{array}{c}\text { Oil }-0 \% \\
\text { Wood }-1.76 \%\end{array}$ & Oil $-0 \%$ \\
\hline
\end{tabular}

Table 7-2: Performance at Reduced Loads

The flue gas flow at full load when firing hog fuel and oil is calculated to be $160,290 \mathrm{cfm}$ at $350^{\circ} \mathrm{F}$ and 5 inches $\mathrm{H}_{2} \mathrm{O}$ Gauge.

The scope of the required boiler modifications is:

- Replace air heater

- Replace economizer

- Add single stage mechanical collector

- Add electrostatic precipitator 
- Add overfire air system (including fan)

- Replace ID fan and add variable speed drive

- New ducting as needed for above systems

- New fuel spreaders (existing width, no pressure part modifications)

- Repair superheaters

- Install new live-bottom (variable-speed metering screws) in hog fuel metering bin

- Install new bottom ash hopper and bottom ash removal system

- Add ash handling systems for both bottom- and fly-ash

- Use existing structural elements of hog fuel delivery system (from storage pile to boiler fuel metering bin), replace all mechanical components

The electrostatic precipitator is designed for a flue gas flow of 200,000 acfm and an inlet maximum particulate loading of 3 grains per acf. The outlet particulate loading is 0.1 grains per dry scf at $12 \% \mathrm{CO}_{2}$ which is equivalent to $99.7 \%$ particulate removal. This level of control is considered "Best Available Control Technology".

The mill plot plan showing the location of the modifications resulting from this project is shown in Figure 7-1 (07194-EM-2A-1). 


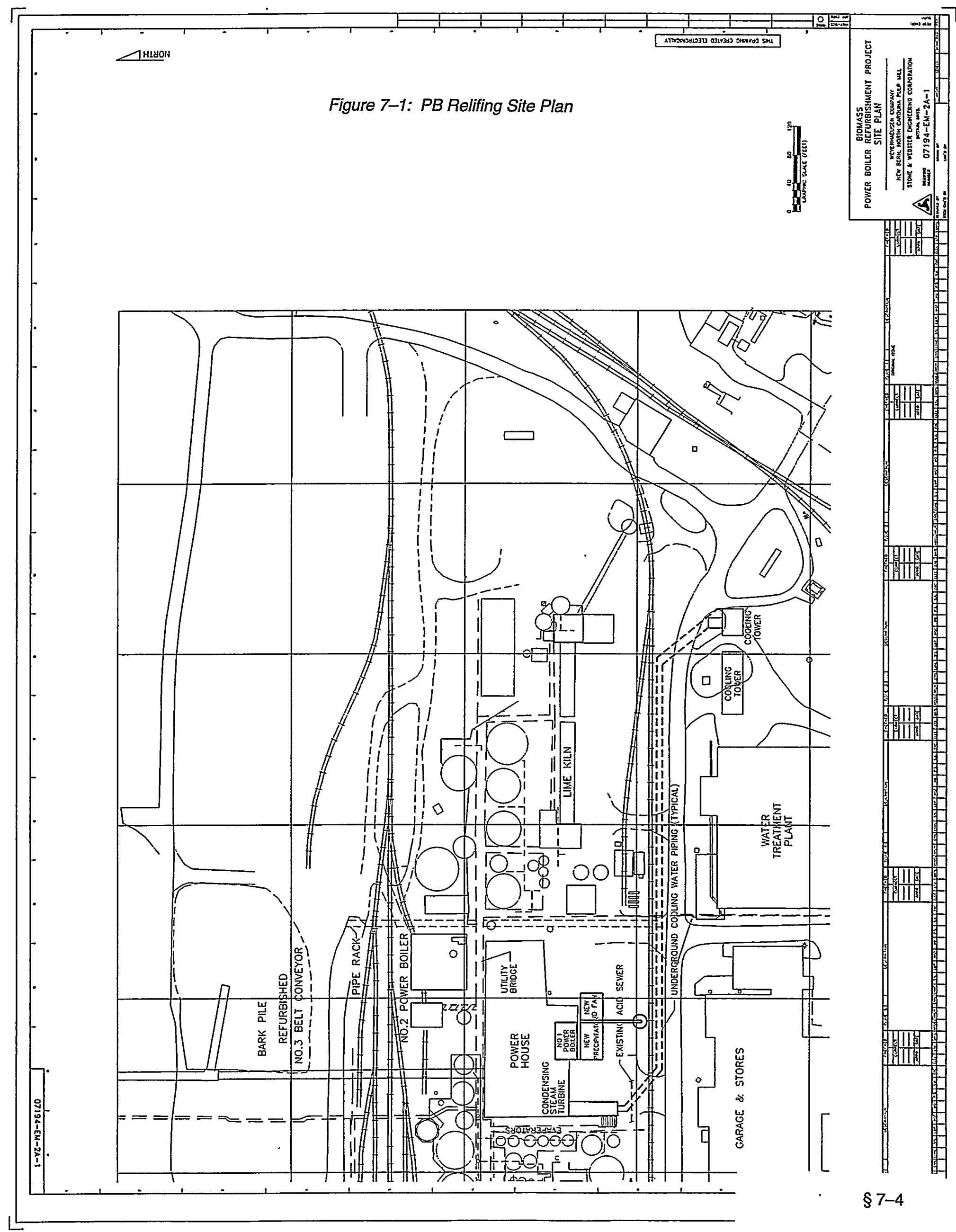




\subsection{System Descriptions}

\subsubsection{Boiler/Flue Gas System Modifications}

The boiler and flue gas system modifications are shown in Figure 7-2 (PFD-PB-001).

The hog fuel is fed to the stoker grate using new fuel spreaders (PBS-FDR1A, B, C, D). A new overfire air fan (PAS-FN1) takes heated primary air from the air heater outlet duct and distributes the air to the overfire air ports. The current standard arrangement for overfire air systems on biomass units is to have large quantities of hot overfire air injected into the furnace through nozzle openings located at various elevations across the front and rear walls. The air admitted through these nozzles is generally $40-50 \%$ of the total air flow requirements.

Flue gas leaves the boiler through a new economizer (PBS-ECON1) and enters the new multiple cyclone type dust collector (FGS-DC1). The dust collector particulate removal efficiency is $80 \%$. The 6 dust collector hoppers discharge into 3 new sand classifiers (FGS-SEP1A,B,C). The sand classifiers recover any char particles for reinjection to the boiler. The overfire air fan is used to provide transport air to reinject the unburned material.

The flue gas then flows through a rebuilt tubular air heater (FGS-AH1). The rebuild includes new tubes and erosion shields.

The flue gas leaving the air heater enters a new induced draft fan (FGS-FN1). The fan moves the flue gas through the electrostatic precipitator (FGS-ESP1) and back to the existing roof-top stack.

Combustion air is supplied by the existing forced draft fan and passes through a replaced steam coil air preheater (PAS-AH1) prior to increasing the cold end temperature of the rebuilt tubular air heater.

\subsubsection{Equipment List}

Fuel Spreaders (PBS-FDR1A,B,C,D) - Modulating air swept feeder-30-40 inches water gauge air pressure; includes feed chute- 7.5 tons/chute capacity with anti-flash back balance air dampers and boiler front plate.

Economizer (PBS-ECON1) $-8,400 \mathrm{ft}^{2}$ of heating surface; $14 \mathrm{ft}$ high $\times 12 \mathrm{ft} 6$ inches wide $\mathrm{x} 17 \mathrm{ft} 6$ inches long; with sootblowers; estimated wt. 80,000 lbs; inlet water temperature $=312^{\circ} \mathrm{f}$; outlet water temperature $=378^{\circ} \mathrm{f}$; inlet flue gas temperature $=$ $725^{\circ} \mathrm{f}$; outlet flue gas temperature $=647^{\circ} \mathrm{f}$, includes lagging and insulation, duct modifications, external piping connections, a relief valve and structural modifications as required.

Overfire Air Fan (PAS-FN1) - 175,000 acfm @ 500 F, 10 inches water gauge with $350 \mathrm{hp}$ motor.

Dust Collector (FGS-DC1) - Multiclone arrangement with a primary dust collector of 360 cyclones, 9 inch diameter each; 3 hoppers wide by 2 deep; includes insulation, lagging, and outlet flanges. 
Sand Classifiers (FGS-SEP1A,B,C) - Vibrating screen type sand classifiers; includes char reinjection system.

Tubular Air Heater (FGS-AH1) - Duty $=38.5 \mathrm{MMBtu} / \mathrm{h}$; air inlet temperature = $80^{\circ} \mathrm{f}$, air outlet temperature $=496^{\circ} \mathrm{f}$; flue gas inlet temperature $=647^{\circ} \mathrm{F}$; flue gas outlet temperature $=360^{\circ} \mathrm{F}$.

Steam Coil Air Preheater (PAS-AH1) - Design air flow 386,000 lbs/hr wet air; Duty $=4.25 \mathrm{MMBtu} / \mathrm{h}$.

Induced Draft Fan (FGS-FN1) - 200,000 acfm, 350 F, 22.5 inches water gauge maximum static pressure; $1000 \mathrm{HP}$ motor with variable speed drive. This motor replaces the steam turbine drive used on the existing induced draft fan.

Electrostatic Precipitator (FGS-ESP1) - 200,000 acfm at $350^{\circ} \mathrm{F}$ and 5 inches water gauge; design pressure 25 inches water gauge; 3 grains per acf inlet loading; $99.7 \%$ collection efficiency; 4 fields; 2 trough type hoppers; $30 \mathrm{ft} 6$ in wide $x 63 \mathrm{ft} 11$ in long including diffusers $\times 53 \mathrm{ft} 10$ in high; includes stand-alone control console with a serial link to the mill DCS. 


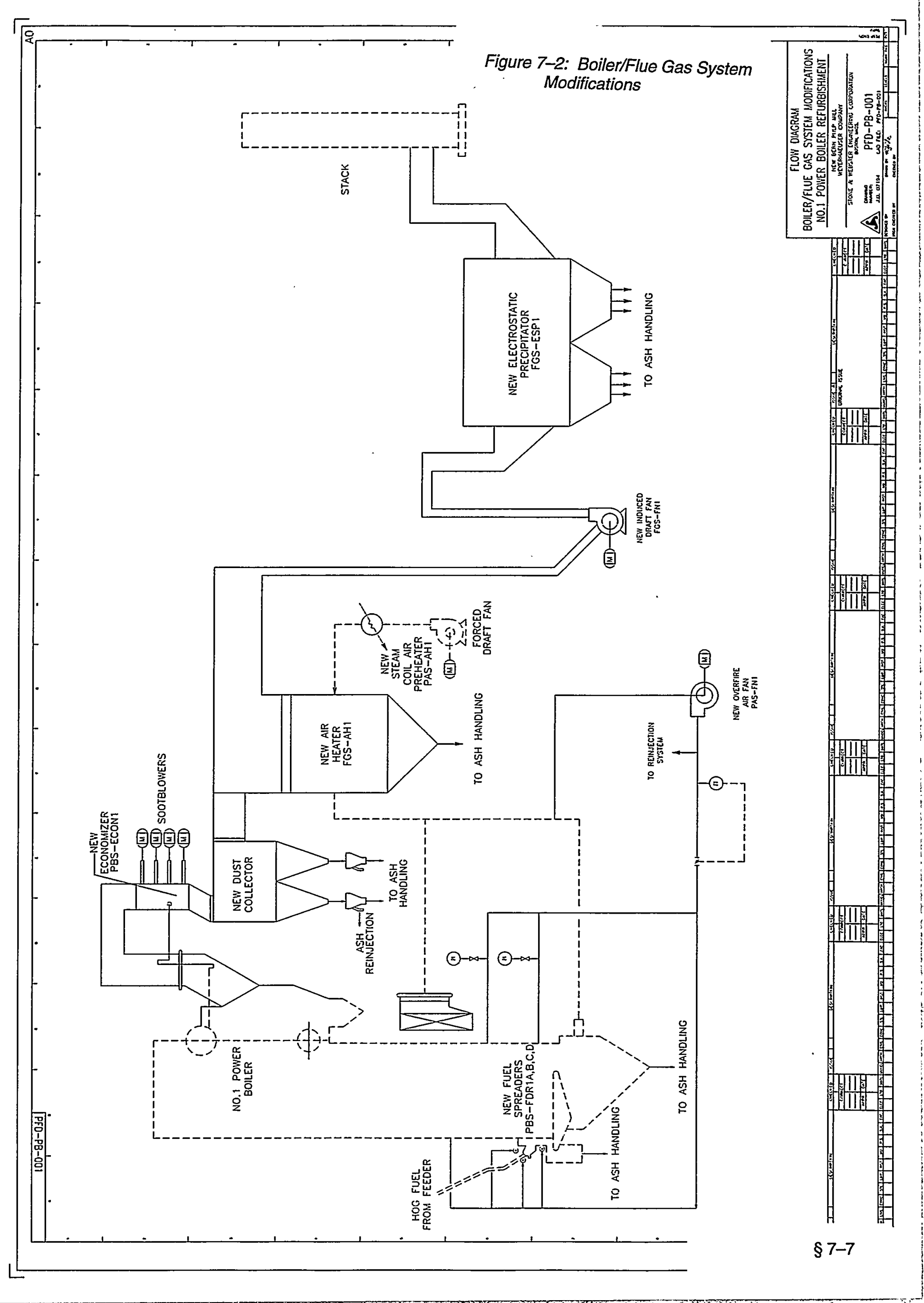




\subsubsection{Condensing Steam Turbine System}

The condensing steam turbine system is shown in Figure 7-3 (PFD-001).

The condensing steam turbine system includes the turbine generator, its control and auxiliary systems, main steam piping from high pressure steam header to the turbine throttle, extraction piping to mill medium pressure and low pressure steam headers, a surface condenser, a condenser air removal system, condensate pumps and condensate piping to existing mill deaerator.

The turbine generator (CST-T1) is a nominal $15 \mathrm{MW}$ machine. Steam is admitted to the throttle at $850 \mathrm{psig} / 825^{\circ} \mathrm{F}$. Steam can be extracted from two stages of the turbine, if desired, to supply the mill's medium pressure ( $155 \mathrm{psig}$ ) and/or low pressure (55 psig) steam headers. The turbine full load exhaust flow with no extractions and a condensing pressure of 3 inches $\mathrm{Hg}$ is $140,000 \mathrm{lb} /$ hour. The extractions are uncontrolled to minimize the turbine cost. Since external controls are employed for the extraction flow and pressure, an exhaust temperature control system is used to ensure that the flow to the exhaust is sufficient to prevent overheating.

The steam exiting the turbine is condensed in a surface condenser (CST-CND1) and the condensate is pumped using one of two $100 \%$ capacity pumps (CST-P1A/B) to the existing mill deaerator. The condenser design duty is $132.5 \mathrm{MMBtu} /$ hour. The design cooling water flow rate is $8,823 \mathrm{gpm}$ based on a $30^{\circ} \Delta \mathrm{T}$.

Each condensate pump is sized for a maximum flow of $280 \mathrm{gpm}$. Since the condensing steam turbine will normally be operating at partial load, the condensate pump discharge will be recycled to the condenser hotwell as required to maintain a minimum hotwell level.

Steam ejectors are used for condenser air removal. The system employs a hogging ejector for start up and a holding ejector for normal operation.

\subsubsection{Equipment List}

Turbine generator (CST-T1) - 15 MW nominal size, with two uncontrolled extractions at $155 \mathrm{psig}$ and $55 \mathrm{psig}$, exhausting at 3 inches $\mathrm{Hg} ; 13.8 \mathrm{kV}$ totally enclosed water to air-cooled generator.

Surface Condenser (CST-CND1) - Heat transfer surface $=18,319 \mathrm{ft}^{2} ; 5 / 8 "$ BWG 304 stainless steel tubes; single pressure, 2-pass.

Condensate Pumps (CST-P1A/B) - 280 gpm horizontal centrifugal pump. 


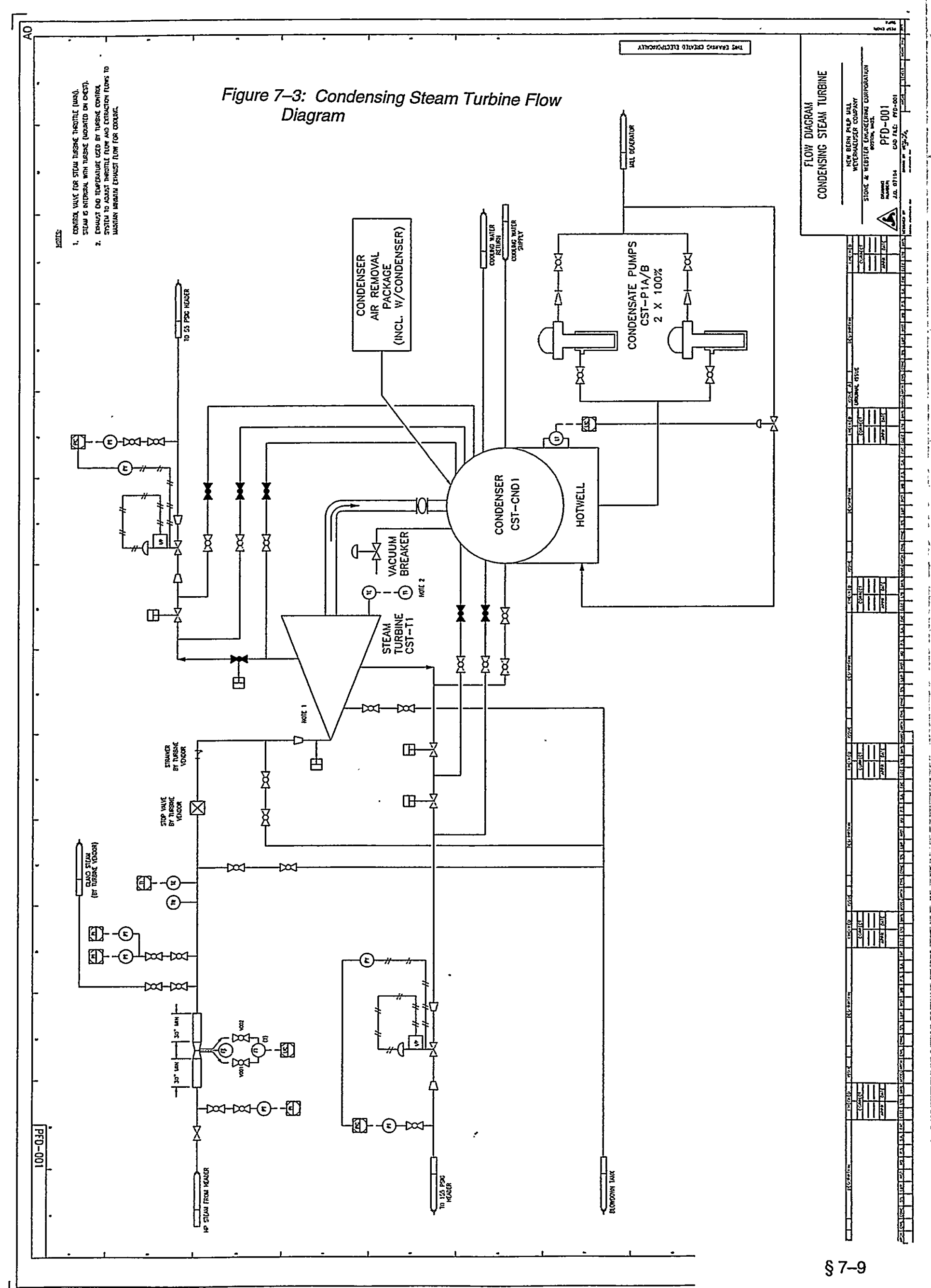




\subsubsection{Wood Handling System}

The wood handling system is shown on process flow diagram Figure 7-4 (PFD-PB002).

The system is designed to provide up to 30 tons/hour of hog fuel (bark, rejects, sawdust and associated material) to the No. 1 power boiler. Approximately 30 tons/ hour of bark, rejects, sawdust, and associated material produced in the existing mill complex are consolidated in the existing hog fuel processing equipment. The No. 1 belt conveyor transports the hog fuel to a transfer station where it is either discharged to the No. 3 belt conveyor for transport to the No. 1 power boiler hog fuel surge bin or discharged to the No. 2 belt stacking conveyor which feeds the hog fuel storage pile.

Material is reclaimed from the storage pile by a chain reclaim conveyor. The reclaim conveyor feeds the hog fuel onto the No. 3 belt conveyor.

All of the equipment already exists. However, the storage pile reclaim conveyor and the No. 3 belt conveyor have been idle since the early 1990s when the mill stopped burning hog fuel in the No. 1 power boiler. These conveyors will be replaced. A new chain reclaim conveyor will be installed in the reclaim pit. The structural components of the No. 3 belt conveyor are sound. These will be reused and a new 30 inch belt and mechanical components (e.g., idlers, pulleys, drive), motor, controls, magnet and belt scale will be provided.

The hog fuel surge bin is equipped with spiked rollers to feed the fuel to the boiler fuel spreaders. These spiked rollers will be removed. A volumetric feeder (WHSFDR1) comprised of 12 screws and 4 motors with adjustable speed control will be added to the bottom of the fuel surge bin to improve fuel feeding.

\subsubsection{Equipment List}

Refurbished No. 3 Belt Conveyor -30 inch wide belt conveyor, rated for 30 tph. Conveyor is $502.28 \mathrm{ft}$ long and is inclined $11^{\circ}-01^{\prime}-42^{\prime \prime}$; final elevation is 99 feet3 inches above grade; includes belt, mechanical components, motor, controls, magnet and scale.

Storage Pile Reclaim Conveyor - Chain conveyor, rated for 30 tph; three 12 inch strands; 53 feet long; inclined $17.8^{\circ}$.

Volumetric Screw Feeder (WHS-FDR1) - 30 tph, carbon steel, 12-14 inch diameter, 14 foot long screws; 4 drives ( 1 per 3 screws), each comprised of a $5 \mathrm{HP}$ motor, 3:1 constant torque controller, gear reducer and chain drive. 


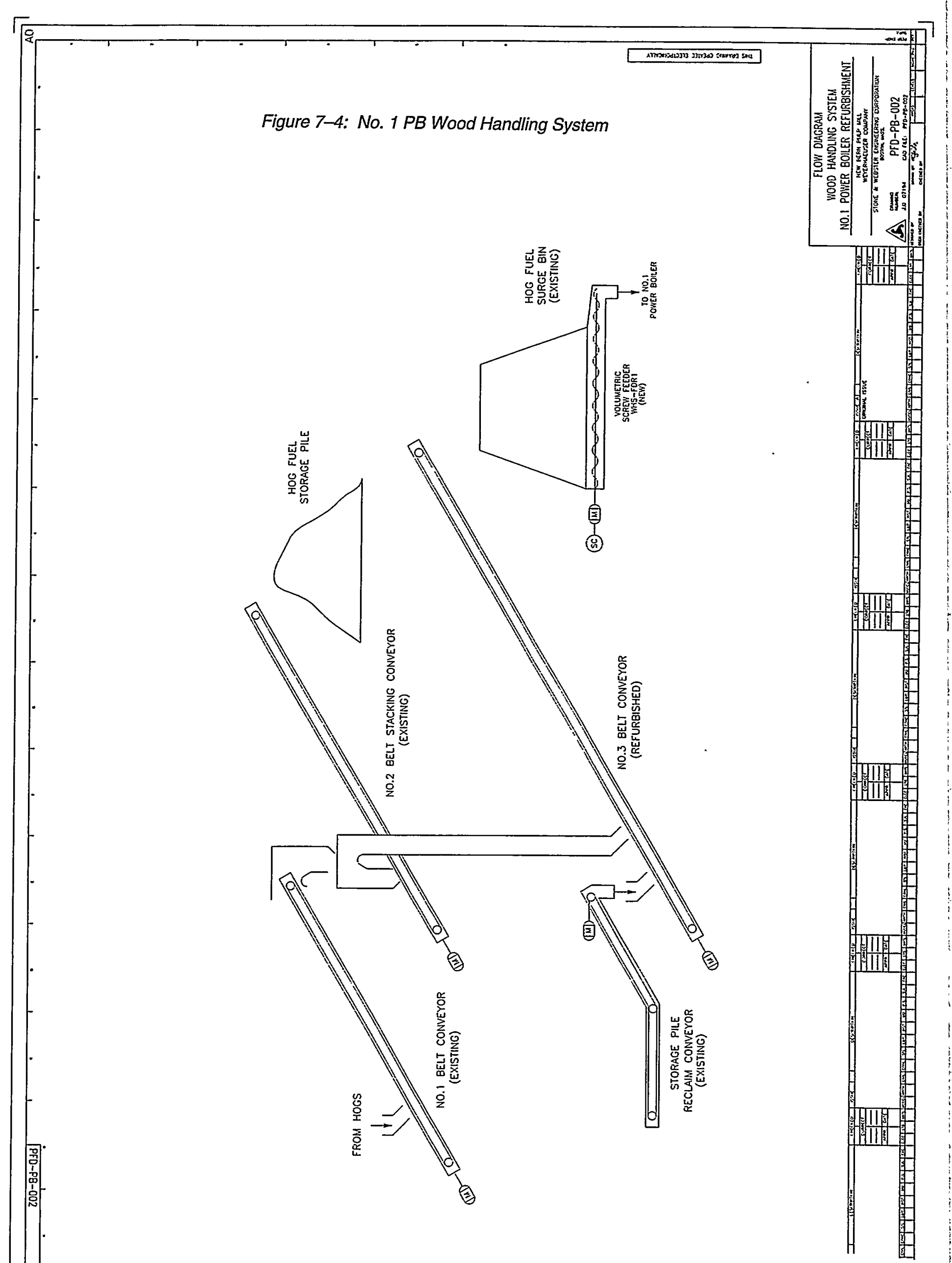




\subsubsection{Ash Handling System}

The ash handling system is shown in Figure 7-5 (PFD-PB-003).

The ash produced from burning hog fuel in the No. 1 power boiler is comprised of stoker siftings, bottom ash and flyash collected in the dust collector, air heater and precipitator. This ash must be removed and disposed of.

Bottom ash falls off the end of the stoker grate into a refractory-lined hopper (AHSHOP1) which directs the ash into a wet (submerged) drag chain conveyor (AHSCNV5). Water is added to this conveyor to maintain a constant level, compensating for water absorbed by the ash and lost to evaporation. Siftings, material that either falls through the grate or drops off the grate as it returns to hog fuel feed end, are collected in a hopper under the stoker grate. This hopper discharges to the siftings conveyor, AHS-CNV4. The siftings conveyor is a dry drag chain conveyor that transfers the siftings to AHS-CNV5. The siftings and bottom ash are transported by AHS-CNV5 to the ash transfer conveyor No. 1 (AHS-CNV6), a dry drag chain conveyor.

Flyash removed by the new mechanical dust collector falls by gravity from three hoppers into double flap airlock valves (AHS-LK1A, B, C). These valves deposit the ash onto the sand classifier conveyor (AHS-CNV1), a dry drag chain conveyor. This conveyor brings this ash to AHS-CNV6 where it joins the bottom ash and siftings.

AHS-CNV6 discharges to the ash transfer conveyor No. 2 (AHS-CNV7), a dry, drag chain conveyor.

Ash which accumulates in the hoppers of the new air heater falls by gravity into double flap airlock valves (AHS-LK2A, B). These valves deposit the ash onto the air heater conveyor (AHS-CNV2), a dry drag chain conveyor. This conveyor discharges the air heater ash to AHS-CNV7 where it joins the siftings, bottom ash and dust collector ash.

The ash removed in the new electrostatic precipitator collects in two trough hoppers and falls by gravity into two ash collecting conveyors (AHS-CNV3A, B). These dry drag chain conveyors each discharges into a double flap airlock valve (AHS-LK3A, B). The airlocks direct the ash onto AHS-CNV7 where it joins the rest of the ash. AHS-CNV7 transfers all the ash to the storage silo.

The ash storage silo (AHS-SILO1) is sized for 24 hours of maximum ash production, assuming a minimum ash density of $20 \mathrm{lb} / \mathrm{ft}^{3}$. The silo is designed to allow a truck to drive under the discharge hopper. The discharge hopper is equipped with an ash conditioning unit (AHS-W1) that wets the ash to increase its density for disposal.

\subsubsection{Equipment List}

Bottom Ash Hopper - Castable refractory-lined hopper; 14 feet long $\mathrm{x} 10$ feet high $\mathrm{x}$ 2 feet wide

Sand Classifier Collector Conveyor (AHS-CNV1) - Design capacity $=4,500 \mathrm{lb} / \mathrm{h}$; $6 \times 18$ single strand drag chain with 33 feet horizontal sprocket centers; operates at 10 fpm; 1 HP motor 
Air Heater Conveyor (AHS-CNV2) - Design capacity $=1,500 \mathrm{lb} / \mathrm{h} ; 2 \times 12$ single strand drag chain with 29 feet horizontal sprocket centers; operates at $10 \mathrm{fpm} ; 1 \mathrm{HP}$ motor

Precipitator Collecting Conveyors (AHS-CNV3A,B) - Design capacity $=0.5$ tph; $2 \times 12$ single strand drag chain with 37 feet horizontal sprocket centers; operates at 10 fpm; 1 HP motor

Siftings Conveyor (AHS-CNV4) - Design capacity $=500 \mathrm{lb} / \mathrm{h} ; 2 \times 12$ single strand drag chain with 17 feet horizontal sprocket centers; operates at $10 \mathrm{fpm} ; 1 \mathrm{HP}$ motor

Bottom Ash Submerged Conveyor (AHS-CNV5) - Design capacity $=0.5$ tph; 2 feet wide with 36 feet horizontal sprocket centers; operates at $10 \mathrm{fpm} ; 2 \mathrm{HP}$ motor

Ash Transfer Conveyor No. 1 (AHS-CNV6) - Design capacity $=5,000 \mathrm{lb} / \mathrm{h} ; 2$ feet6 inches wide double strand design with 75 feet true sprocket centers; operates at $10 \mathrm{fpm}$ up a $40^{\circ}$ incline to discharge into top of ash silo; $3 \mathrm{HP}$ motor

Ash Transfer Conveyor No. 2 (AHS-CNV7) - Design capacity $=3$ tph; 2 feet6 inches wide double strand design with 112 feet true sprocket centers; operates at 10 fpm up a $40^{\circ}$ incline; $2 \mathrm{HP}$ motor

Double Flap Airlock (AHS-LK1A,B,C) - Design capacity = 1,500 lb/h; design pressure $=5$ inches $\mathrm{H}_{2} \mathrm{O}$

Double Flap Airlock (AHS-LK2A,B) - Design capacity $=750 \mathrm{lb} / \mathrm{h}$; design pressure $=5$ inches $\mathrm{H}_{2} \mathrm{O}$

Double Flap Airlock (AHS-LK3A,B) - Design capacity = 1,000 lb/h; design pressure $=5$ inches $\mathrm{H}_{2} \mathrm{O}$

Ash Silo (AHS-SKLO1 - Steel silo 20 feet diameter, 37 feet height with $60^{\circ}$ bottom cone; bottom outlet 20 ' above grade

Ash Conditioning Unit (AHS-W1) - Design capacity $=30 \mathrm{tph}$; maximum ash inlet temperature $=300^{\circ} \mathrm{F}$; includes all valves, fittings feeders from silo bottom outlet through truck loading outlet 


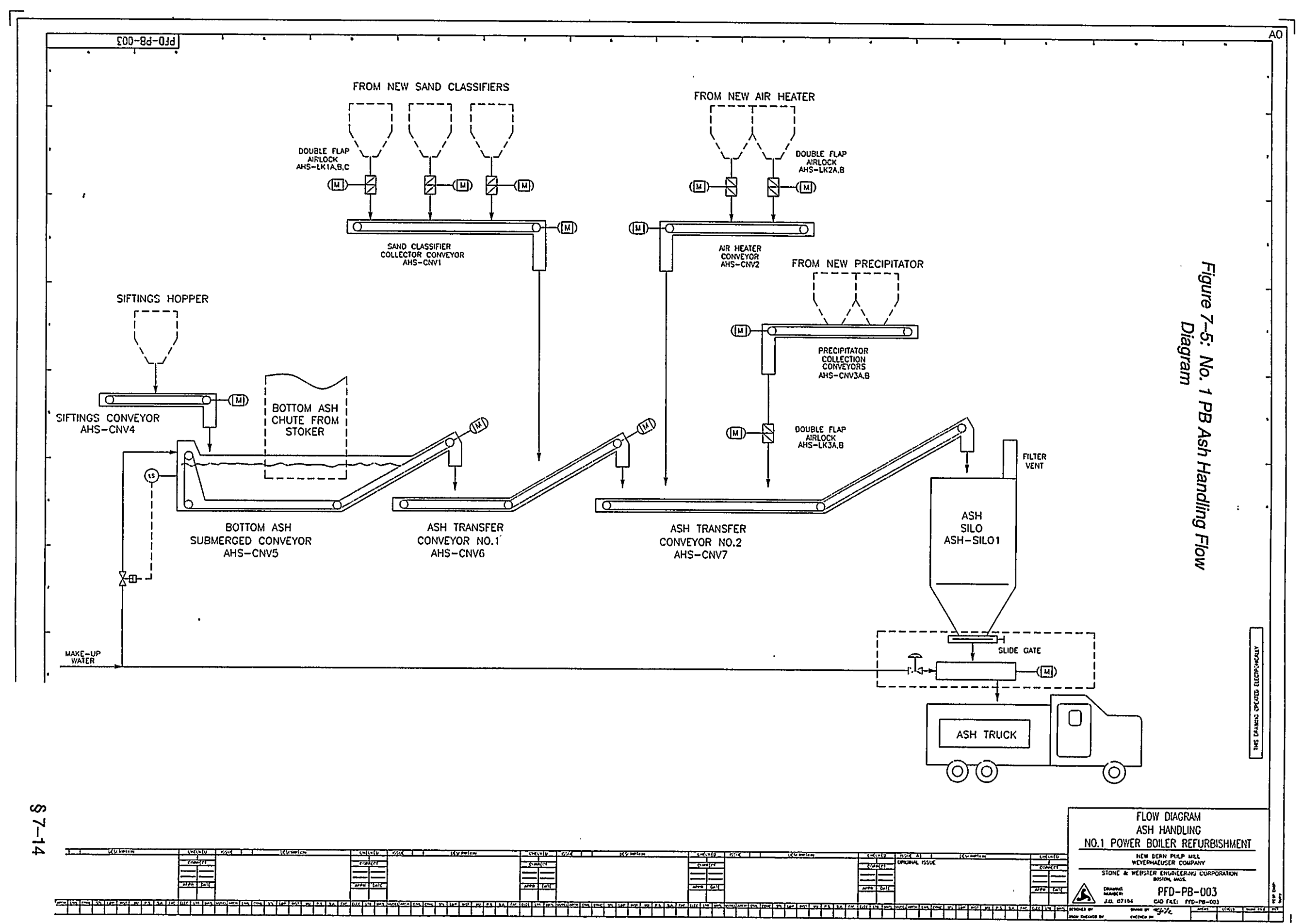




\subsubsection{Cooling Water System}

The cooling water system is shown in Figure 7-6 (PFD-PB-005). The system is designed to meet the following cooling requirements:

- Condensing steam turbine condenser $8,823 \mathrm{gpm} @ 30^{\circ} \Delta \mathrm{T}$

- Condensing steam turbine lube oil cooler $200 \mathrm{gpm} @ 20^{\circ} \Delta \mathrm{T}$

- Condensing steam turbine generator cooler $260 \mathrm{gpm} @ 20^{\circ} \Delta \mathrm{T}$

The total circulating water flow is $9,283 \mathrm{gpm}$.

The system is a closed cycle utilizing a single cell mechanical draft cooling tower (CWS-TWR1).

Two $50 \%$ capacity circulating water pumps (CWS-P1A,B) take suction from the cooling tower basin and distribute the water to the specified users and back to the cooling tower fill.

The cooling tower blowdown rate is established to maintain the required water solids levels. The make up water to the tower is controlled by the water level in the basin.

\subsubsection{Equipment List}

Cooling Tower (CWS-TWR1) - Single cell 48 feet long by 36 feet wide counterflow mechanical draft cooling tower with single speed fan; tower cooling duty $=137 \mathrm{MMBtu} / \mathrm{h}$

Circulating Water Pumps (CWS-P1A,B) - 4700 gpm vertical centrifugal pumps 


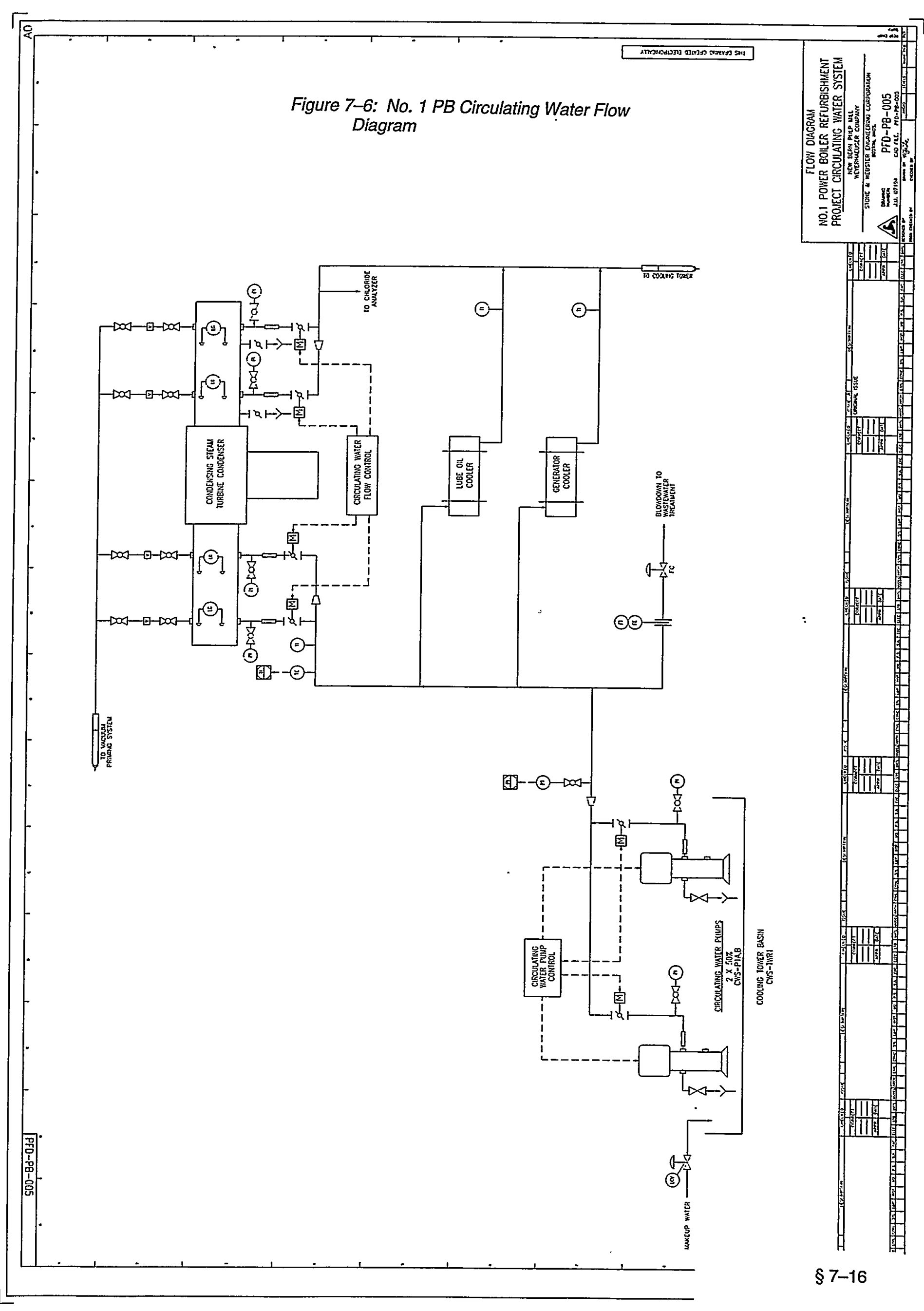




\subsubsection{Other Utility/Infrastructure Requirements}

The other project utility and infrastructure requirements include:

- Instrument air

- Electrical interconnections

- Interconnections to mill DCS

The additional electrical loads total about $1.5 \mathrm{MW}$ as follows:

\begin{tabular}{|lc|}
\hline Boiler Relifing Project Additional Electrical Loads \\
\hline & kWe \\
Overfire Air Fan & 261 \\
Induced Draft Fan & 746 \\
Condensate Pump & 18 \\
Ash Handling & 9 \\
Wood Handling & 100 \\
Circulating Water Pumps & 163 \\
Cooling Tower Fan & 85 \\
Electrostatic Precipitator & 117 \\
Steam Turbine Auxiliaries & 19 \\
Misc. & 10 \\
& $1528 \mathrm{kWe}$ \\
\hline
\end{tabular}

Table 7-3: Additional Electrical Loads

\subsection{Capital Cost Estimate}

\subsubsection{Estimate Approach}

Stone \& Webster prepared the estimate by updating previous estimates for the No. 1 power boiler relifing that had been developed by CRS Sirrine and Jacobs-Sirrine, and adding the costs for reactivation of the hog fuel transfer and feeding system and installation of the condensing steam turbine. Sirrine had prepared a Weyerhaeuser Class 10 estimate in 1991. The Class 10 estimate is intended to have an accuracy of $\pm 10 \%$. To achieve this accuracy requires substantial design work. Sirrine produced major equipment specifications, arrangement drawings, piping \& instrumentation drawings, one-line diagram, electrical load list, instrument list and control I/O list. The estimate was generated from major equipment quotations and quantity takeoffs for development of bulk material quantities.

Jacobs-Sirrine updated their estimate in December, 1994. The 1991 estimate included a secondary dust collector and a new stack. The 1994 estimate did not include these items. Sirrine updated the estimate by deleting the items removed from the project scope of work, obtaining new prices for the major equipment and adjusting labor rates and bulk material costs. 
The present scope of work for relifing of the No. 1 power boiler includes the following items that were not in the 1994 Jacobs-Sirrine estimate:

- New tubular air heater

- New steam coil air heater

- Superheater repairs

- New fuel spreaders

- Grate repairs

- New bark pile reclaim conveyor

- New conveyor from wood yard to boiler fuel bin

The extent of superheater and grate repairs has not been defined, so an allowance developed from experience was included for these items. Stone \& Webster obtained budget prices for the other new items and estimated the associated installation cost. Current budget prices were also obtained for the major equipment previously estimated by Sirrine. The Sirrine labor rates and bulk material prices were adjusted to present day. Stone \& Webster estimated the costs for the condensing steam turbine addition which necessitated a new single cell cooling tower.

Based on the estimating approach, this estimate is considered to be between a preliminary cost estimate (Class 20) and a detailed (Class 10) estimate. The estimate accuracy range should be $\pm 15 \%$.

\subsubsection{Estimating Basis and Assumptions}

The capital cost estimate was developed based on the following assumptions:

- Cost data are based on a January 2000 price level.

- Owners' costs are not included.

- Cost of permits, applications and inspections by governmental bodies not included.

- No clearing \& grubbing required.

- No mass earthwork; no allowance for site remediation.

- Excavated material is suitable for structural backfill.

- No subdrains or special drainage provisions; water table is below the lowest level of excavation.

- No storm drains.

- Only paving included is for access to ash storage silo.

- No material will be disposed of off site.

- There is no provision for sales tax.

- All major foundations rest on precast concrete piles with average length of $60 \mathrm{LF}$.

- Electrical cables are routed in tray supported from pipe/utility bridge (no underground routing). 
- The only underground systems are cooling water to/from the main mill pipe bridge to the condensing steam turbine condenser and electrical grounding.

- No allowance for price/wage escalation has been provided. Project duration is expected to be about 18 months.

- Engineering, procurement, and other management/administration costs ("Home Office Cost") have been estimated as a percentage of the constructed cost of the plant. The percentage used is typical for projects in this cost range.

\subsubsection{Estimate Components}

\subsubsection{Direct Field Material Costs}

Direct field material costs are for permanent physical plant facilities. They include the following elements:

- Equipment. Equipment includes all machinery used in the completed facility, such as boilers, rotating machinery, heat exchangers, tanks, and vessels.

- Material. Materials include concrete, steel, building materials, pipe and fittings, valves, wire and conduit, instruments, insulation, and paint used in constructing the completed plant.

- Freight. Freight to the job site is included.

\subsubsection{Direct Field Labor Costs}

The components of direct field labor costs are labor manhours and the composite labor wage rate.

\subsubsection{Direct Subcontract Costs}

Direct subcontract costs are those for equipment, materials, and services furnished by the subcontractors, including installation labor costs and related indirect field costs.

Major items that were estimated as subcontract costs include:

- Boiler modifications (fuel feed, grate, economizer, superheater, air heater, ash reinjection)

- Condensing steam turbine relifing and reinstallation

- Cooling tower

- Electrostatic precipitator

- Ash handling equipment

\subsubsection{Indirect Field and Home Office Engineering Costs}

Indirect field costs are costs that cannot be directly identified with any construction operation related to specific plant facilities but that support the general construction operation. 
These costs for indirect labor and materials include allowances for the following items:

- Miscellaneous construction services (labor) covering cleanup, maintenance of tools and construction equipment, security, surveying and testing.

- Temporary construction

- Materials including temporary buildings and roads, utilities and services, scaffolding, testing, construction equipment, tools and consumables.

- Construction non-manual personnel

Home office engineering manhours and other home office services cover the expenses of the following items:

- Labor for engineering design, procurement, technical services, administrative support, and project management services

- Office expenses such as materials, telephone, reproduction and computer costs, and travel

\subsubsection{Contingency}

A project contingency of $12.5 \%$ is applied. Weyerhaeuser's Standardized Project Process utilizes an 8 to $10 \%$ contingency. However, based on the size of this project, the contingency was increased.

\subsection{Boiler Relifing Project Cost Estimate}

The capital cost for the boiler relifing project is $\$ 22.7$ million as shown in Table 7-4.

\subsection{Operating \& Maintenance Costs}

\subsubsection{Staffing Requirements}

Additional Control Room Operators Wood yard

Roving Operators
1 per shift

1 per shift

0.5 per shift

TOTAL
$=4$

$=4$

$=2$ 
TABLE 7-4

NO. I POWEA BOILER RELIFING PROJECT

CAPITAL COST ESTIMATE

Basis: January 2000

Item

Material

Labor

Subcontract Total Cost

\section{PLANT SYSTEMS}

Boiler Relifing

Site Modifications

Buildings

Conveyor Repairs

Electrostatic Precipitator

Ash Handling

Boiler Modifications

Foundations

Piping

Electrical \& Instrumentation

Building Services

Condensing Steam Turbine

Buildings

Equipment

Foundations

Piping

Electrical \& instrumentation

Building Services

Cooling Water

Site Modifications

Equipment

Foundations

Piping

Electrical \& Instrumentation

TOTAL DIRECT COST

$\begin{array}{rrrr}6,000 & 175,000 & 31,000 & \$ 212,000 \\ 73,000 & 109,000 & 3,000 & \$ 185,000 \\ 185,000 & 30,000 & & \$ 215,000 \\ 1,320,000 & & 620,000 & \$ 1,940,000 \\ 910,000 & 104,000 & & \$ 1,014,000 \\ 1,789,000 & 886,000 & 3,048,000 & \$ 5,723,000 \\ 285,000 & 465,000 & 167,000 & \$ 917,000 \\ 70,000 & 206,000 & 74,000 & \$ 350,000 \\ 1,310,000 & 576,000 & & \$ 1,886,000 \\ 151,000 & 198,000 & 3,000 & \$ 352,000\end{array}$

$\begin{array}{rrrr}66,000 & 4,000 & 40,000 & \$ 110,000 \\ 1,556,000 & & 1,222,000 & \$ 2,778,000 \\ 75,000 & 125,000 & & \$ 200,000 \\ 90,000 & 40,000 & & \$ 130,000 \\ 40,000 & 15,000 & & \$ 55,000 \\ 16,000 & 5,000 & & \$ 21,000\end{array}$

$\begin{array}{rr}2,000 & 4,000 \\ 81,000 & 27,000 \\ 23,000 & 63,000 \\ 290,000 & 130,000 \\ 43,000 & 22,000\end{array}$

$\begin{array}{rr} & \$ 6,000 \\ 219,000 & \$ 327,000 \\ \$ 86,000 \\ \$ 420,000 \\ \$ 65,000\end{array}$

$\$ 8,381,000 \quad \$ 3,184,000 \quad \$ 5,427,000 \quad \$ 16,992,000$

HOME OFFICE

FIELD NON-MANUAL

TOTAL INDIRECT COST

TOTAL DIRECTS + INDIRECTS

PROJECT CONTINGENCY (12.5\%)

$\$ 2,025,000$

$\$ 1,125,000$

$\$ 3,150,000$

$\$ 20,142,000$

$\$ 2,518,000$

TOTAL INSTALLED COST

$\$ 22,660,000$ 


\section{Section 8}

\section{Economics of New Bern Alternatives}




\subsection{Economics of New Bern Alternatives}

\subsection{Approach}

Economic viability of the FERCO-LIVG (Low Inlet Velocity Gasification) technology at the New Bern mill is assessed using standard incremental economic evaluation techniques. The analysis is done in nominal-dollar terms. The costs and benefits of the Gasification Project described in Section 5 are assessed based on thermodynamic performance, operating requirements of the defined project, New Bern site energy demands and in the context of current and future projections of relevant unit cost parameters.

This assessment will focus on economic viability of the LIVG process configured to meet the thermal and electrical requirements of the New Bern site. Given that emerging technologies such as LIVG process must offer benefits beyond what is currently available to warrant consideration by potential users, LIVG process economics will be compared to an analogous conventional technology alternative. The No. 1 Power Boiler Relifing Project, described in Section 7, is defined and evaluated as the conventional technology alternative for minimizing fossil fuel dependence at New Bern. Like the gasification case, this option attempts to make maximum utilization of existing on-site equipment by modifying the No. 1 power boiler to facilitate biomass fuel utilization. Unlike the gasification case, this alternative does not allow biomass utilization by multiple fuel users-the mill lime kiln and No. 2 power boilers continue to be fired by fossil fuel. Economics of the two process options will be compared for the default set of economic assumptions. Sensitivity analysis and the impact of potential public policy incentives to encourage broader use of biomass fuels will focus on the LIVG process option.

Both biomass options are compared to a base case which defines current and projected future operating costs and minimum capital requirements for continued reliable steam generation for the site. The base case presumes that the status quo will continue with \#6 fuel oil as the primary non-recovery fuel used at New Bern. A maintenance capital investment of $\$ 1.8$ million is included in the base case in order to relife the No. 1 power boiler to a level of reliability and longevity that is consistent with the No. 1 Power Boiler Relifing Project. Likewise, $\$ 1.8$ million in additional capital expenditure is also added to the Gasification Project alternative for the same reason. This maintenance capital figure was derived from capital cost estimate for the No. 1 Power Boiler Relifing Project and is part of that project's scope. Maintenance capital costs include superheater repairs and replacement of both the air heater and economizer

The New Bern-specific analysis will take a "Next Plant" perspective as the New Bern project has been proposed as an early demonstration of the LIVG technology. "Nth Plant" economic potential of the LIVG technology will be discussed in a subsequent section of this report.

\subsection{Overview of Alternatives}

Table 8-1 below summarizes the major impacts of the two alternative biomass projects on the fuel and purchased power requirements of the New Bern mill. Default capital cost values 
for the alternatives are also included. Mill steam requirements were estimated based on historical process data and future production plans. The hourly average fuel requirements shown below are based on a month-by-month annual assessment that takes into account seasonally-induced variation in mill thermal requirements as well as the operational constraints of the mill's two power boilers. These constraints include such items as boiler turndown limits, minimum support fuel requirements for non-condensable gas destruction, and keeping boilers in a suitable load range for response to modulating steam needs of the facility.

\begin{tabular}{|c|c|c|c|}
\hline Parameter & $\begin{array}{l}\text { Base Case: Oil as } \\
\text { Non-Recovery Fuel }\end{array}$ & $\begin{array}{l}\text { No: } 1 \text { P/B Biomass } \\
\text { Retrofit w/CST }\end{array}$ & Biomass Gasifier with CST \\
\hline Capital Cost & $\$ 1.8$ million & $\$ 22.7$ million & $\begin{array}{l}\$ 69.7 \text { million (Next Plant) } \\
\$ 57.6 \text { million (Nth plant) }\end{array}$ \\
\hline $\begin{array}{l}\text { Oil Use for Steam } \\
\text { Generation }\end{array}$ & $45.4 \mathrm{Bbl} / \mathrm{hr}$ & $22.7 \mathrm{Bbl} / \mathrm{hr}$ & 8.7 Bbl/hr \\
\hline Lime Kiln Fuel & $15.8 \mathrm{Bbl} / \mathrm{hr}$ & $15.8 \mathrm{Bbl} / \mathrm{hr}$ & Biomass gas \\
\hline $\begin{array}{l}\text { Disposition of Site } \\
\text { Fuel Residuals }\end{array}$ & Sell $187,000 \mathrm{GT} / \mathrm{yr}$ & To No. 1 P/B & To Biomass Gasifier \\
\hline $\begin{array}{l}\text { Purchased Biomass } \\
\text { Fuel }\end{array}$ & None & $\begin{array}{l}52,500 \mathrm{GT} / \mathrm{yr} \text { to } \\
\text { No. } 1 \mathrm{P} / \mathrm{B}\end{array}$ & $\begin{array}{c}371,000 \text { GT/yr to Biomass } \\
\text { Gasifier }\end{array}$ \\
\hline $\begin{array}{l}\text { Added Electrical } \\
\text { Connected Load }\end{array}$ & N/A & $1.5 \mathrm{MW}$ & $5.4 \mathrm{MW}$ \\
\hline $\begin{array}{l}\text { Purchased Electric } \\
\text { Power }\end{array}$ & $6.0 \mathrm{MW}$ & Self-Sufficient & Self-Sufficient \\
\hline
\end{tabular}

Table 8-1: Overview of Project Alternatives

The figures in Table 8-1 are based on annual biomass and fossil fuel requirements and thus, represent "mid-season" conditions while the New Bern mill is running at its target production rate. As is seen in the table, the gasifier alternative does not completely eliminate fossil fuel use at the site. The system has been sized to ensure high gasifier system capacity utilization on a year-around basis. During summer months, the gasifier system is turned down slightly, due to the lower seasonal thermal loads. During winter months, non-recovery thermal loads exceed gasifier capability necessitating that some fuel oil still be used.

\subsection{Analytical Method, Assumptions and Key Inputs}

As stated above, alternatives were evaluated using incremental economic evaluation methods. The net benefits of each alternative are reduced to an after-tax cash flow stream. Escalation factors are applied to the various operating costs to account for the impacts of inflation. Capital expenditures are considered as pure equity investments; there are no leverage impacts due to the effects of debt financing. Net present value and internal rate of return are calculated for each alternative in accord with the following analytical framework: 
Life of projects - Twenty five years

Nominal inflation rate $-2.5 \% / \mathrm{yr}$.

Combined tax rate $-38 \%$ (includes State and Federal)

Discount rate $-12 \%$ (for net present value calculations)

Investment tax credits (North Carolina-specific) - 5\%, 15\% for biomass projects

Depreciation schedules - Fifteen year double-declining balance, five year DDB for biomass projects.

Project residual values - Based on after-tax cash flow in last year of operation

The operating cost/benefit impacts of each biomass alternative are considered in the following cost categories:

Biomass fuel cost/revenue - Manufacturing residuals at the New Bern site are currently sold. In each biomass alternative, all internal residuals are consumed as fuel at the expense of the current sales revenue. Both options require additional purchase of biomass fuels in the local market at prices based on the supply analysis presented in Section 2. Biomass fuel prices are escalated at the nominal rate of inflation (zero percent real price escalation).

Fuel oil - Biomass fuel utilization displaces \#6 fuel oil use in the No. 1 and No 2 power boiler and the lime kiln in the gasification alternative. In the boiler retrofit case, \#6 fuel oil use is only displaced in No. 1 power boiler. Fuel oil prices have fluctuated significantly over the last two years; this analysis is based on an initial (year 2000) price of $\$ 20 /$ barrel. Fuel oil price real escalation is assumed at a default value of $0.1 \% / y r$. This value is based on data presented in the Energy Information Administration (ELA) Annual Energy Outlook 2000 publication for their "Reference Case". The impact of these assumptions on project viability will be investigated through sensitivity analysis.

As seen in Table 4-4 in the LIVG process energy and material balance, the LIVG process does not consume all the dryer exhaust steam. This analysis assumes that a reboiler is installed to generate low pressure steam from this heat source, and that a suitable use can be found for this steam that displaces high pressure steam generation. This thermal credit brings the overall thermal efficiency of the gasification island to $89.4 \%$ where thermal efficiency is defined as:

(HHV of product gas + heat export from product gas $\mathrm{HRSG}+$ heat export from dryer exhaust)

HHV of biomass fuel input to gasifier

This high level of thermal efficiency is considered to be near the upper bound of what is achievable in applying the LIVG process technology. For this reason, no increase in thermal efficiency will be assumed to occur between "Next Plant" and "Nth Plant" when discussing the economics of generic "Nth Plant" technology applications (see Section 9).

Purchased electric power - In each biomass alternative, additional power is generated via the new condensing steam turbine to displace all purchased load and 
offset the added auxiliary loads imposed by the project itself. In practice, it is recognized that a power grid connection would be maintained with the potential for electric power flow in either direction between the mill and the electric power grid. The default value assumed for the displaced purchased load is $\$ 0.05 / \mathrm{kWh}$ with sensitivities run at $\$ 0.04$ and $\$ 0.06 / \mathrm{kWh}$. Although electric power industry deregulation is under discussion in North Carolina, there is not yet a clear basis for regional projection of future electric power price escalation. Real escalation assumptions for the market value of electric power are based on Energy Information Agency national projections as follows :

$\begin{array}{ll}2001-2005 & -0.5 \% / \mathrm{yr} . \\ 2006-2010 & -1.0 \% / \mathrm{yr} . \\ 2011-2015 & +0.7 \% / \mathrm{yr} . \\ 2016 \text { to end of project } & -0.3 \% / \mathrm{yr} .\end{array}$

The above escalation rates assume regulated electricity rates prevail until 2005; competitive market assumptions are used from 2006 through the end of project life.

Operating labor - Labor for the biomass alternatives is added based on the staffing requirements estimated in Section 5.5.1. Fully loaded labor rates of $\$ 22 / \mathrm{hr}$. are used and are assumed to escalate at the nominal inflation rate.

Maintenance costs - Expensed maintenance labor and materials are estimated to be $3.5 \%$ of initial capital per year escalated at the nominal inflation rate. Maintenance capital is added at $3 \% / y r$. These values are based on pulp and paper industry experience and data.

Boiler Feedwater, Waste Water Treatment, Cooling Water and Miscellaneous Chemicals/Operating Supplies - Allowances are made on a case-specific basis and escalated at the nominal inflation rate.

\subsection{Results and Discussion}

\subsubsection{Results}

Results of the economic analysis are shown in the following paired graphics, Figures 8-1 through 8-16. Return on investment (ROI) and net present value (NPV) are displayed as functions of invested capital. When an acceptable ROI "hurdle rate" is specified, the figures allow estimation of how much capital can be spent to capture the economic benefits provided by the project. The economic value of the project can then be estimated from the accompanying NPV graphic. In all figures, the green trend lines represent the use of the "default" assumptions for all parameters (except capital cost).

The following sensitivities are investigated independently:

- Sensitivity to oil initial price and escalation assumptions Figures 8-1 and 8-2.

- Average biomass fuel price (outside purchased fuels): Figures 8-3 and 8-4.

\footnotetext{
${ }^{1}$ Annual Energy Outlook 2000; Energy Information Agency
} 
- Value of displaced purchased electricity: Figures 8-5 and 8-6.

- Sensitivity to maintenance expense and capital assumptions: Figures 8-7 and 8-8.

- Figures 8-9 and 8-10 compare ROI and NPV vs. capital trends for the LIVG Project and for the No. 1 Power Boiler Relifing Project.

- The potential impact of two public policy-based incentives to encourage expanded use of biomass fuels is also investigated. Figures 8-11 and 8-12 demonstrate how LIVG project ROI and NPV are affected by a $\$ 1.00 / \mathrm{MBtu}$ biomass fuel gas tax credit.

- Figures 8-13 and 8-14 demonstrate the potential impact of tax credits associated with reduction of atmospheric carbon emissions, assuming that biomass substitution (from renewable sources) for fossil fuels would qualify for such tax credits.

- Figures 8-15 and 8-16 create a favorable scenario for biomass utilization by moving several key economic factors in a direction which makes biomass fuel use more attractive. This scenario benefits the No. 1 Power Boiler Relifing Project as well as the Gasifier alternative.

Table 8-2 summarizes the default assumptions used in this analysis and embodied in Figures 8-1 through 8-16. A discussion and interpretation of these figures follows Figure 8-16. 


\begin{tabular}{|c|c|}
\hline Parameter & $\cdots \cdots \quad: \quad, \quad$ Default Value \\
\hline General inflation rate, \% & $2.5 \%$ \\
\hline Discount rate, $\%$ & $12 \%$ \\
\hline Income tax rate, $\%$ & $38 \%$ \\
\hline Investment tax credit & $\begin{array}{l}15 \% \text { for biomass projects } \\
5 \% \text { for other capital projects }\end{array}$ \\
\hline Tax depreciation & $\begin{array}{l}5 \mathrm{yr} \text {. double declining balance for biomass projects } \\
15 \mathrm{yr} \text {. double declining balance for other capital projects }\end{array}$ \\
\hline Project life & 25 years \\
\hline Residual fuel oil price, \$/Bbl. & $\$ 20.00$ \\
\hline Real escalation rate - residual fuel oil, \% & $0.1 \%$ \\
\hline Average Power Price, $₫ / \mathrm{kWh}$ & $5 \phi$ \\
\hline $\begin{array}{l}\text { Real escalation rate - purchased electric } \\
\text { power }\end{array}$ & 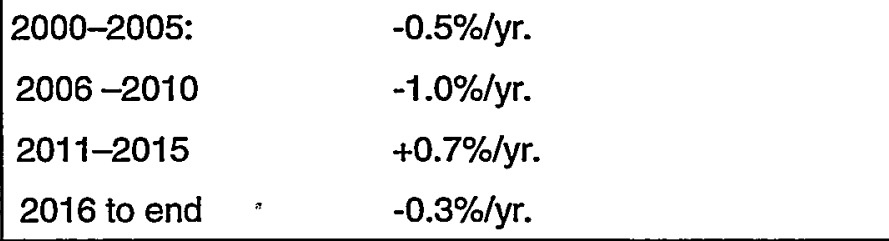 \\
\hline Average biomass price, \$/BDT & $\$ 18$ (at Gasifier Project volume) \\
\hline $\begin{array}{l}\text { Maintenance capital requirement, \% of } \\
\text { capital/yr. }\end{array}$ & $3.0 \%$ \\
\hline $\begin{array}{l}\text { Maintenance materials and labor, } \% \text { of } \\
\text { capital/yr. }\end{array}$ & $3.5 \%$ \\
\hline Capacity Factors (based on 365 day year) & $\begin{array}{l}\text { Mill- } 92 \% \\
\text { Gasifier Project- } 88 \% \\
\text { Boiler Relifing Project- } 90 \%\end{array}$ \\
\hline Start Up Dates & $\begin{array}{l}\text { Gasifier Project- } 2003 \\
\text { Boiler Relifing Project- } 2002\end{array}$ \\
\hline Capital Spending Period & $\begin{array}{l}\text { Gasifier Project- Two Years } \\
\text { Boiler Relifing Project- One Year }\end{array}$ \\
\hline
\end{tabular}

Table 8-2: Summary of Default Economic Assumptions (New Bern Alternatives Case) 

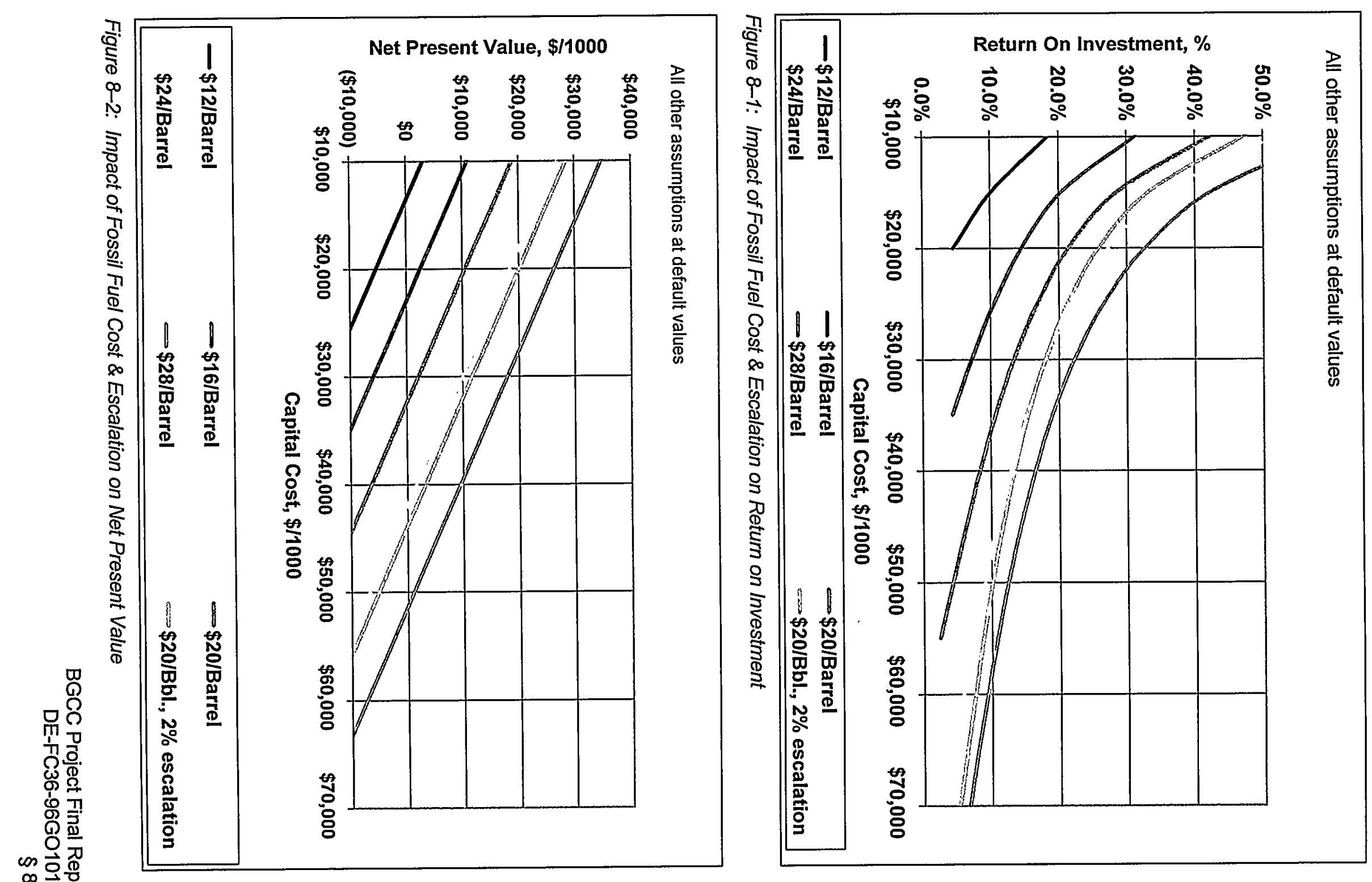

州岕 
All other assumptions at default values

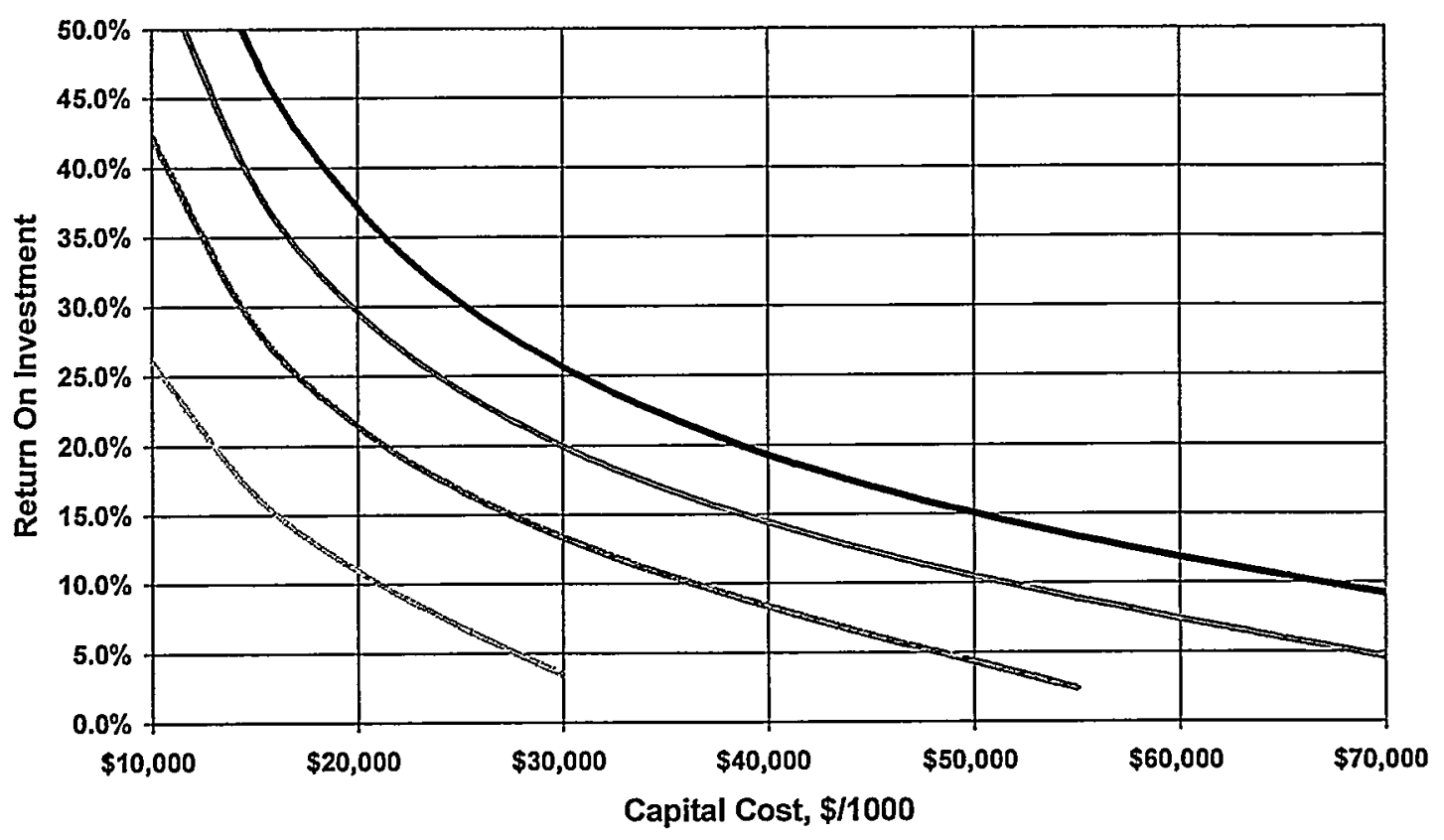

Decrease \$20/BDT $\Longrightarrow$ Decrease \$10/BDT Default (\$18/BDT) $=$ Increase \$10/BDT

Figure 8-3: Impact of Average Biomass Fuel Cost on Return on Investment

All other assumptions at default values

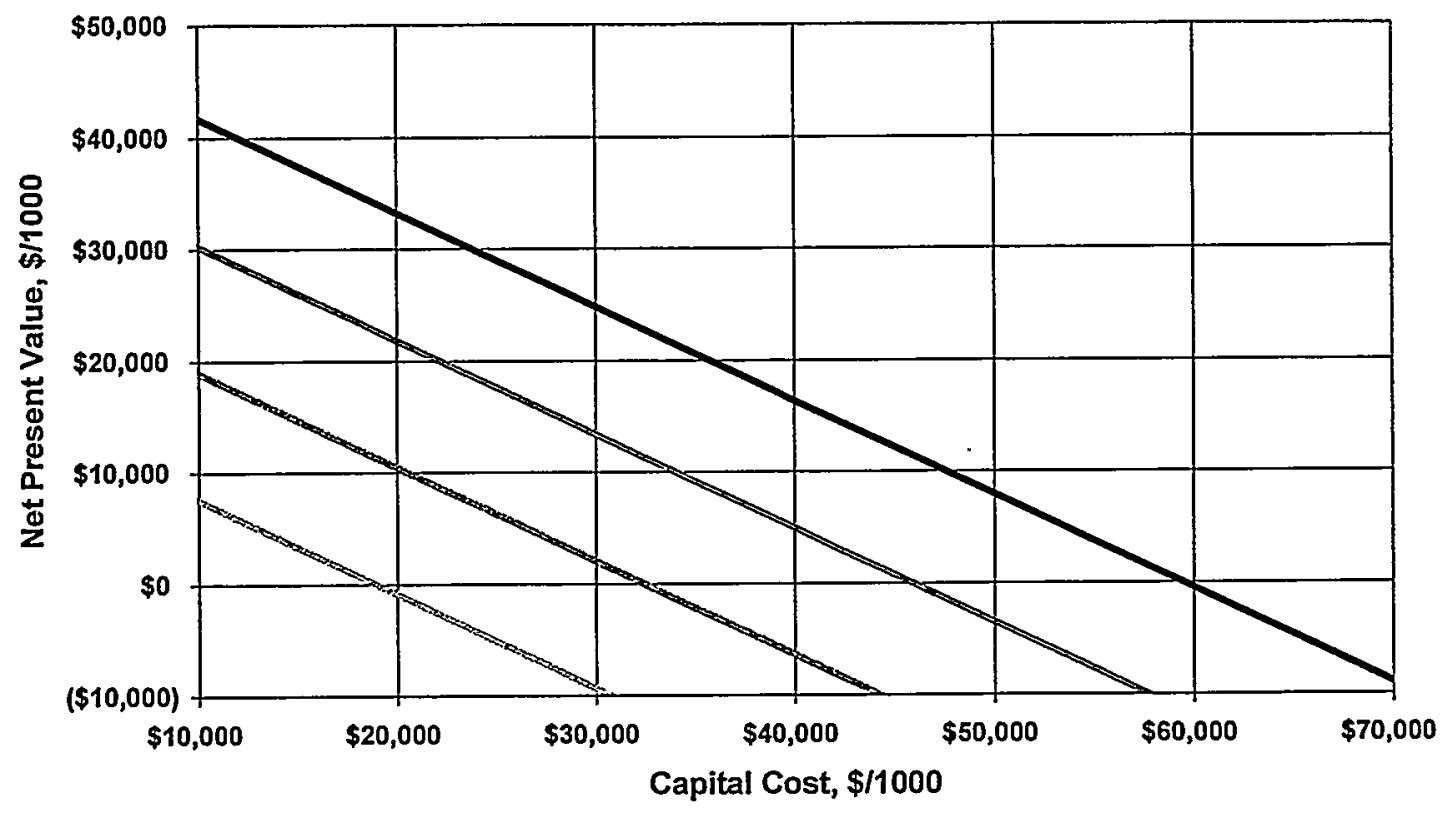

Figure 8-4: Impact of Average Biomass Fuel Cost on Net Present Value 
All other assumptions at default values

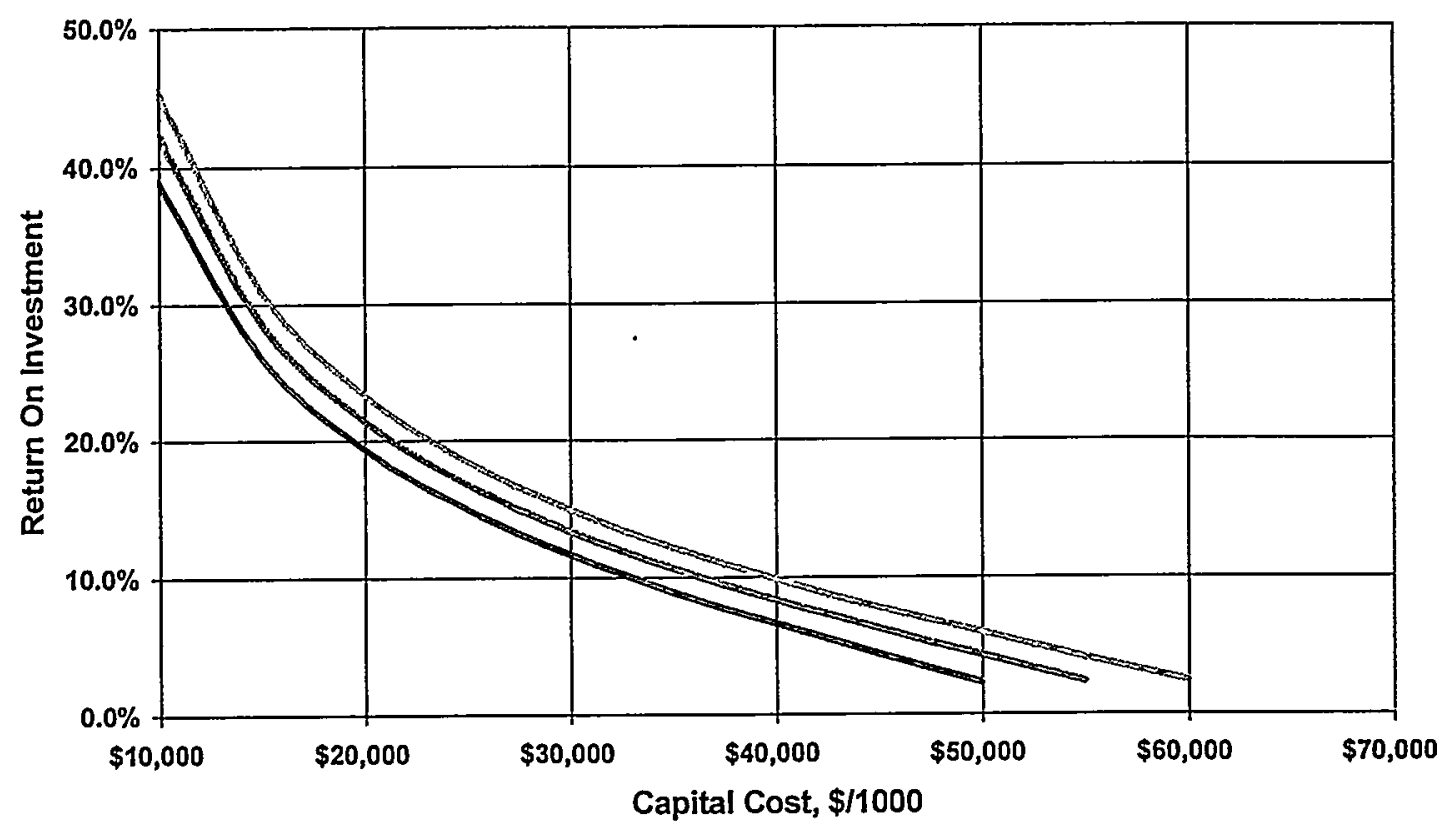

$-\$ 0.04 / \mathrm{kWh}$ $\$ 0.05 / \mathrm{kWh}$ $\$ 0.06 / \mathrm{kWh}$

Figure 8-5: Impact of Displaced Purchased Power Value on Return on Investment

All other assumptions at default values

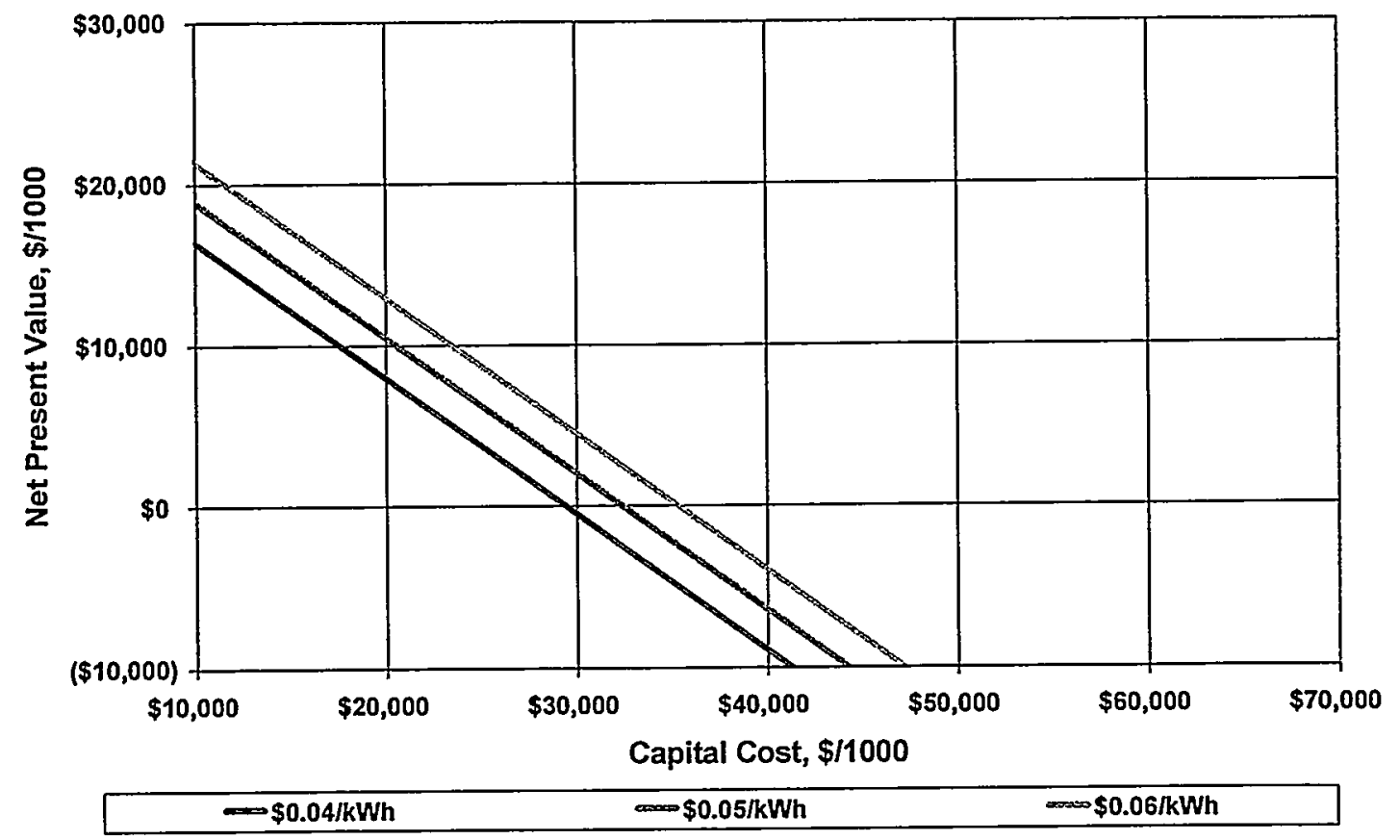

Figure 8-6: Impact of Displaced Purchased Power Value on Net Present Value

BGCC Project Final Report DE-FC36-96G010173 
All other assumptions at default values

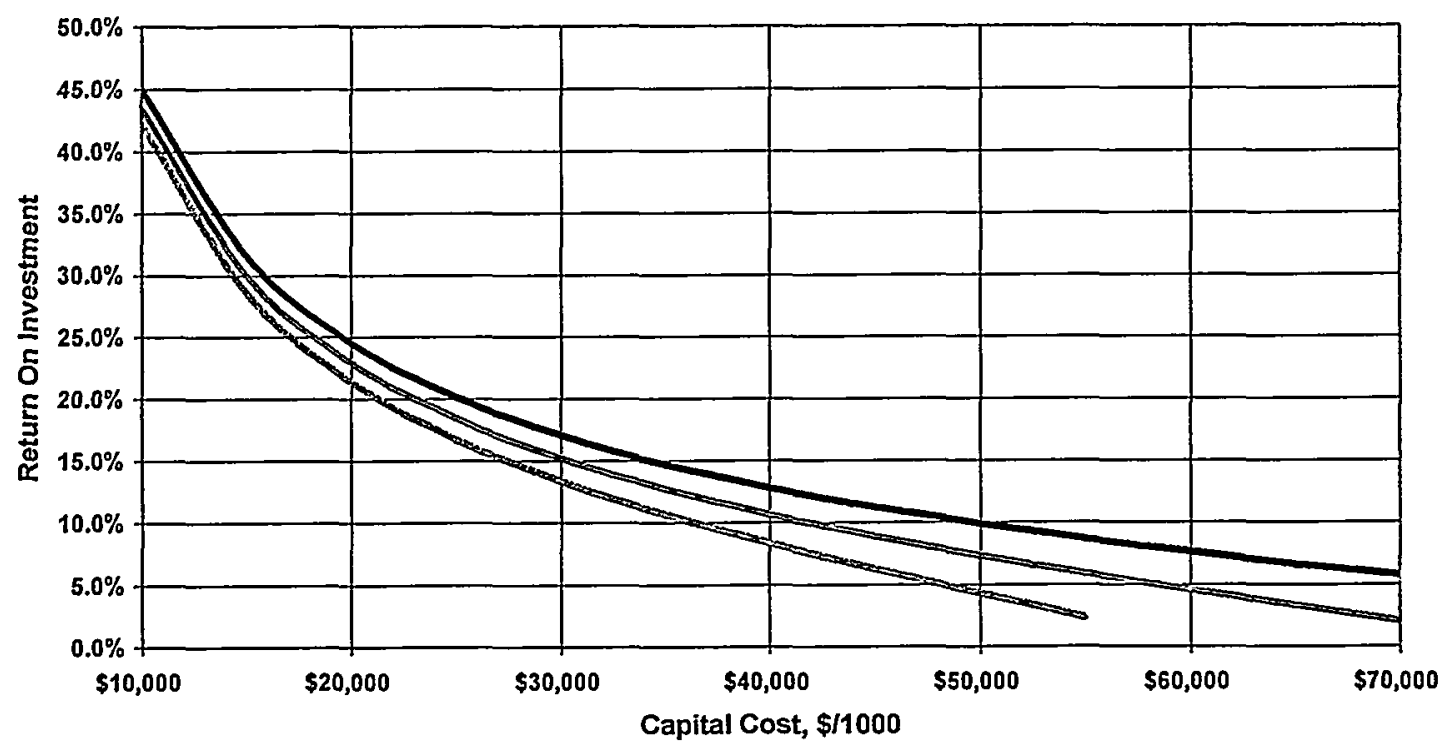

Default-Mtce. Materials/Labor @ 3.5\% of Capital, Mtce. Capital @ 3.0\% of Capital/Yr.

Reduce to $2.5 \%$ Mat'Is/Labor \& 2\% Mtce. Capital

- Reduce to $1.5 \%$ Mat'ls \& Labor \& $1.0 \%$ Mtce. Capital

Figure 8-7: Impact of Maintenance Cost Assumptions on Return on Investment

All other assumptions at default values

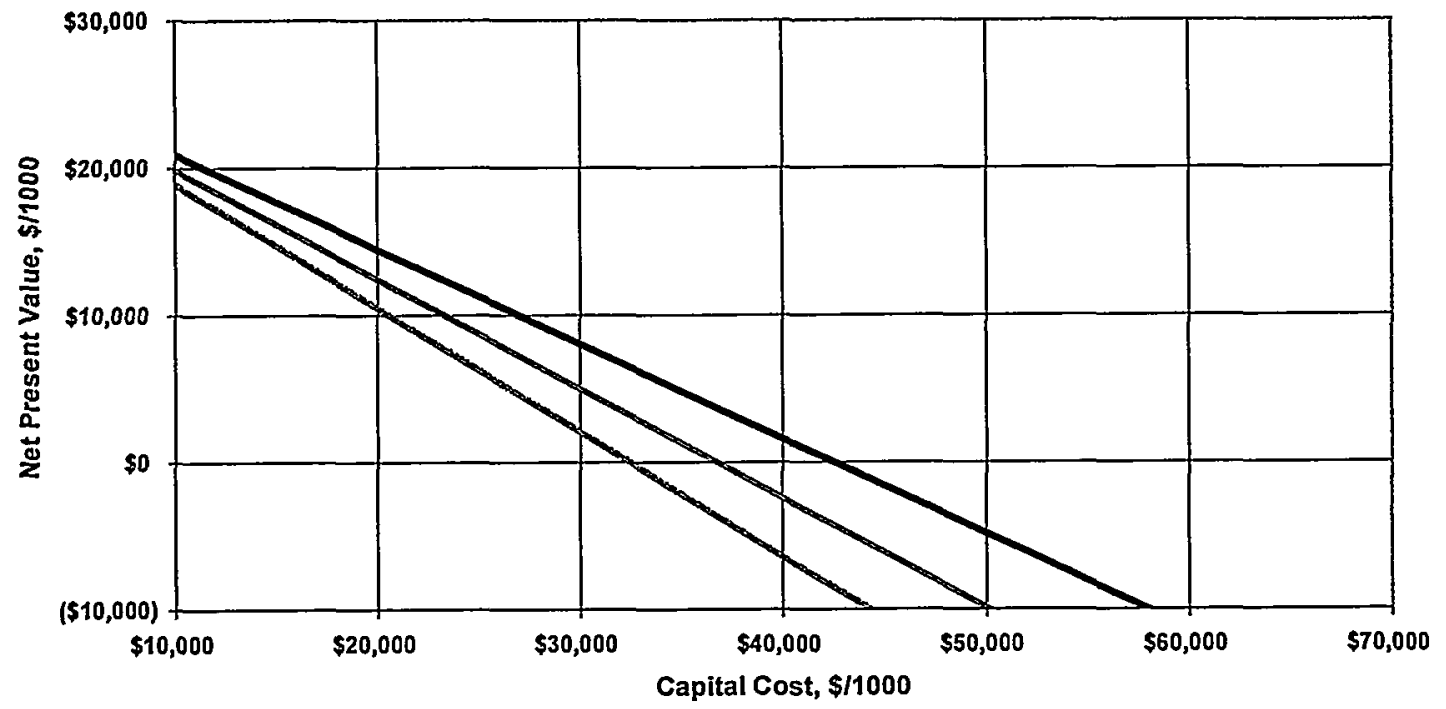

Default-Mtce. Materials/Labor @ 3.5\% of Capital, Mtce. Capital @ 3.0\% of Capital/Yr.

Reduce to $2.5 \%$ Mat'Is/Labor \& 2\% Mtce. Capital

-Reduce to $1.5 \%$ Mat'ls \& Labor \& $1.0 \%$ Mitce. Capital

Figure 8-8: Impact of Maintenance Cost Assumptions on Net Present Value

BGCC Project Final Report

DE-FC36-96G010173 
All other assumptions at default values

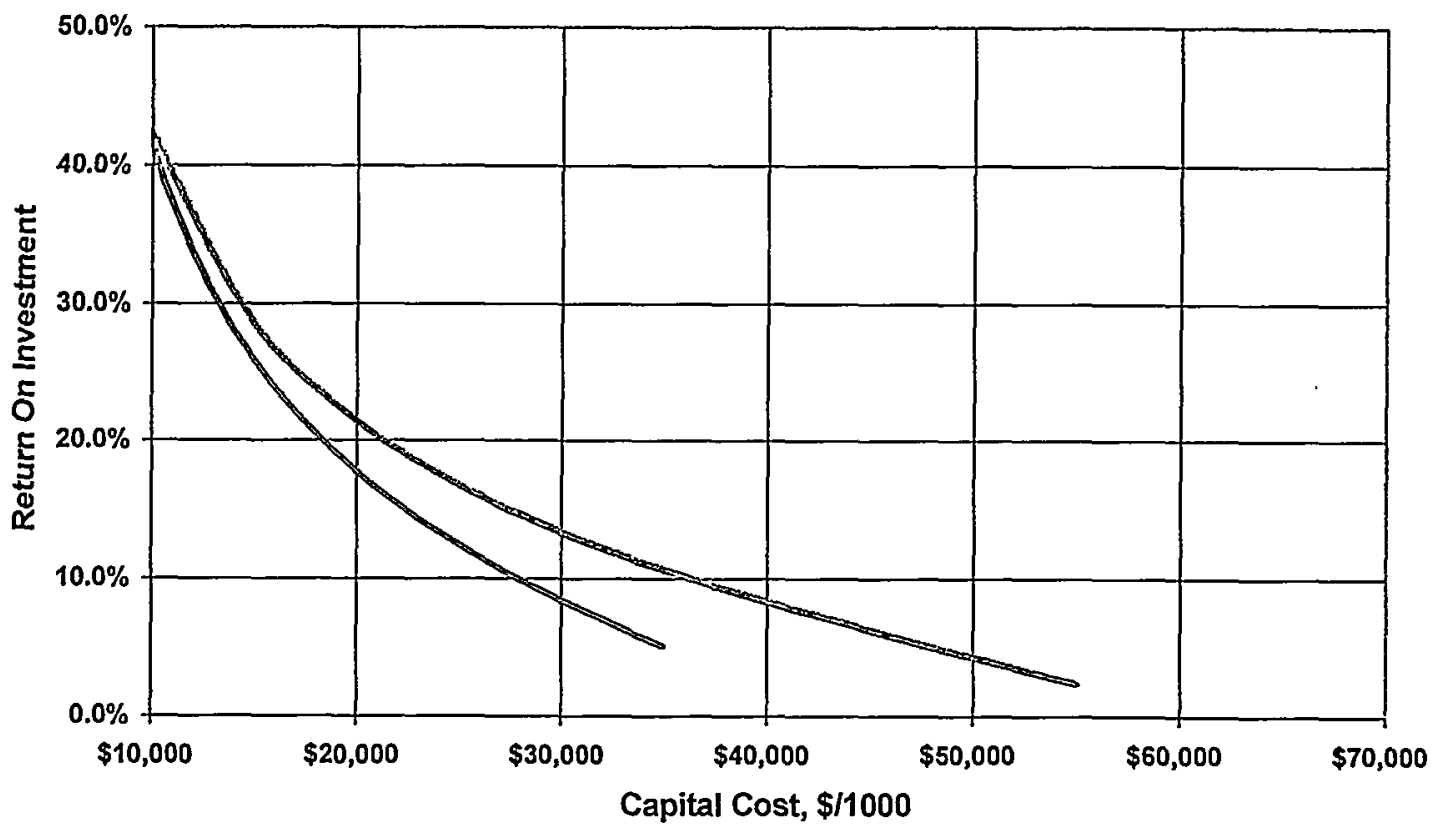

Ferco/Battelle LIVG Project \#1 Power Boiler Biomass Conversion Project

Figure 8-9: Comparison with No. 1 Power Boiler Relifing Project-Return on Investment All other assumptions at default values

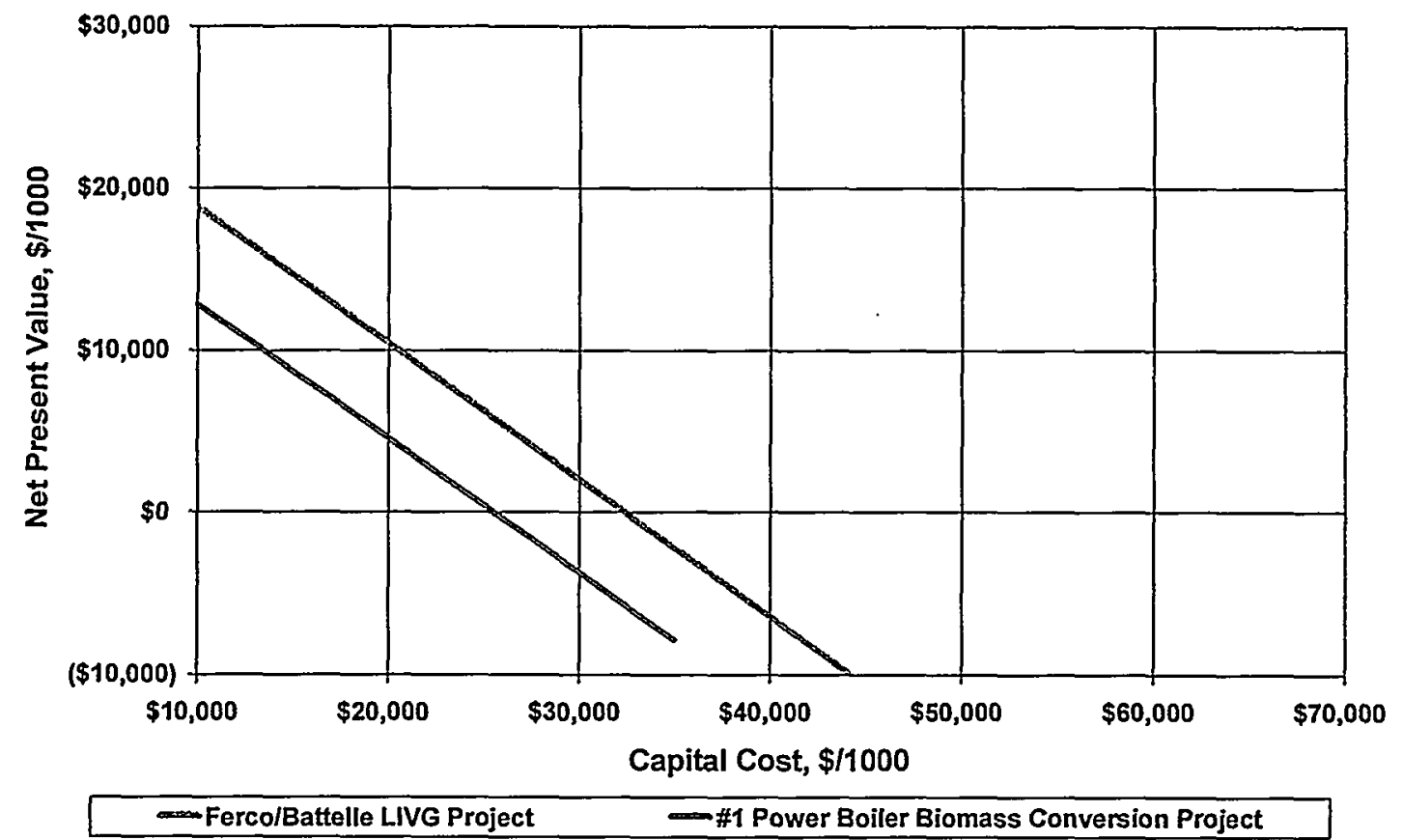

Figure 8-10: Comparison with No. 1 Power Boiler Relifing Project-Net Present Value 


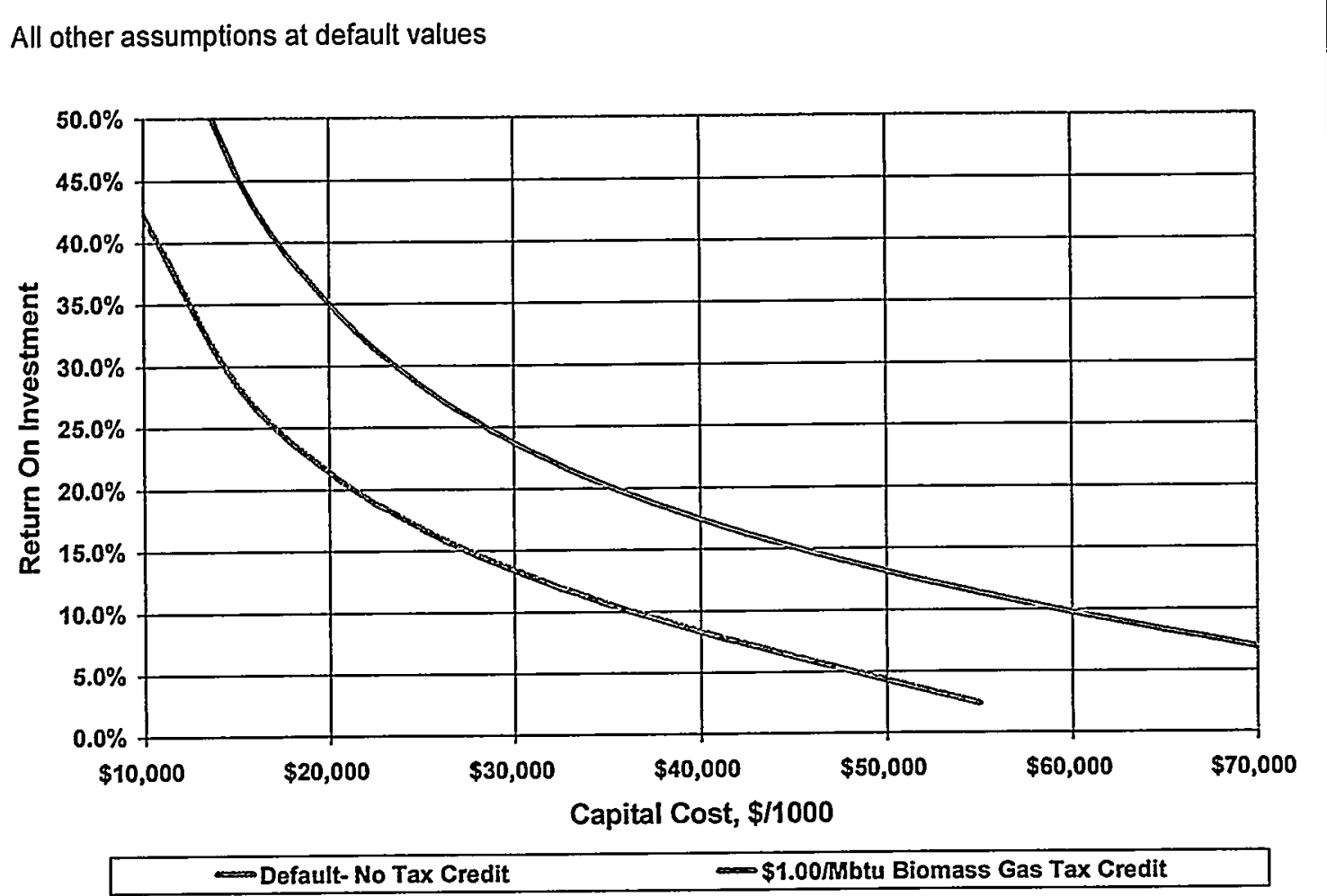

Figure 8-11: Impact of Fuel Gas Tax Credit on Return on Investment

All other assumptions at default values

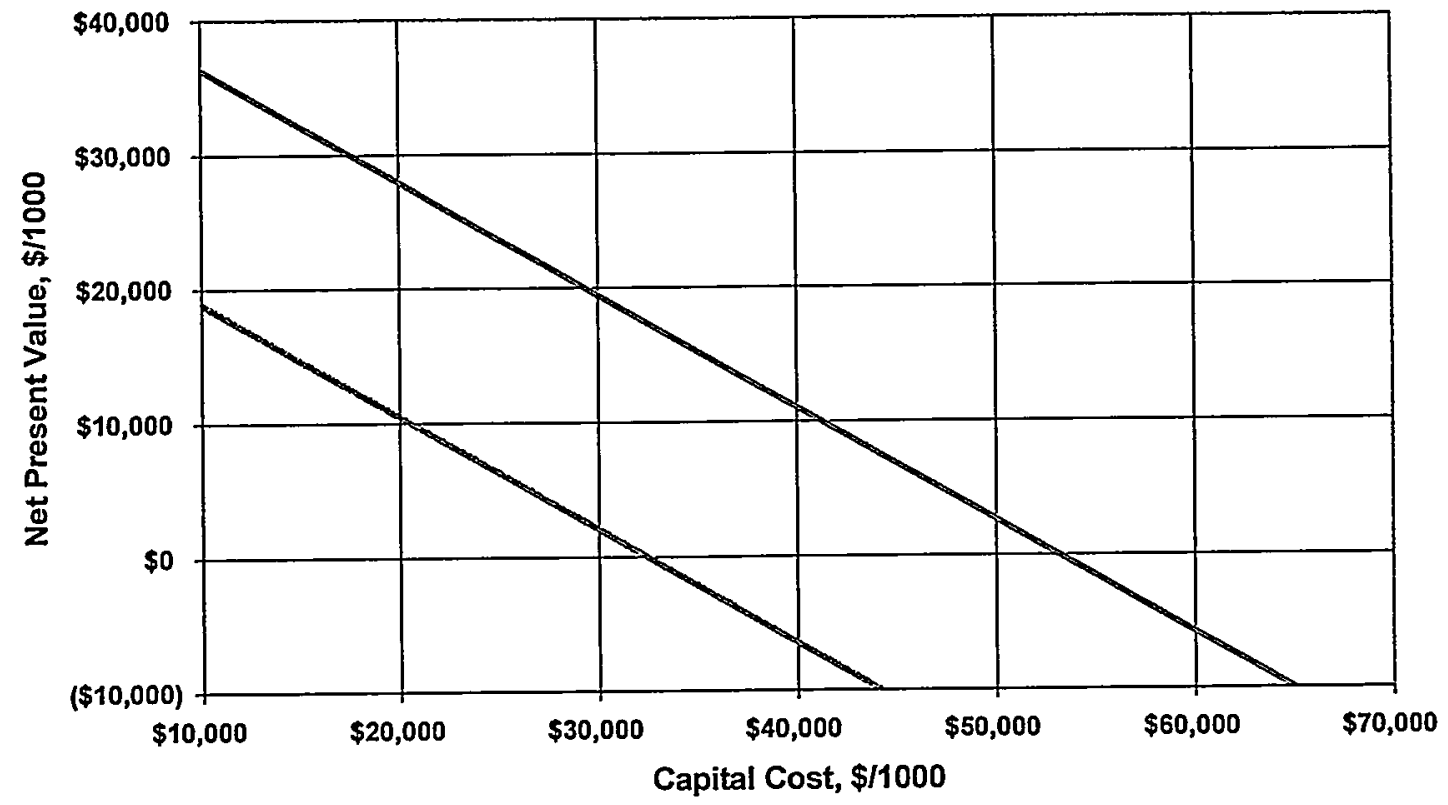

Default- No Tax Credit

$\longrightarrow$ \$1.00/Mbtu Biomass Gas Tax Credit

Figure 8-12: Impact of Fuel Gas Tax Credit on Net Present Value

BGCC Project Final Report DE-FC36-96G010173 


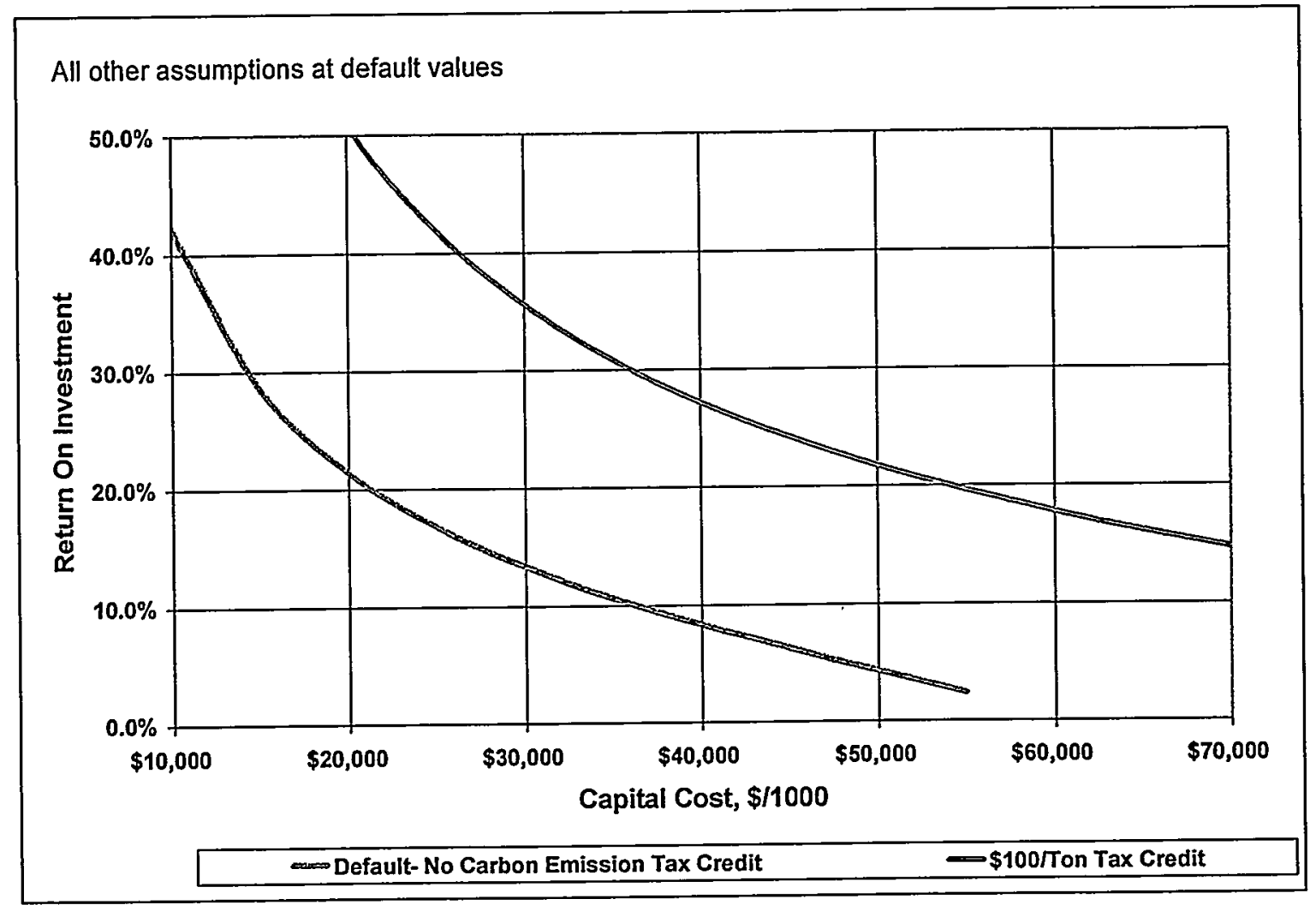

Figure 8-13: Impact of Tax Credits for Avoided Carbon Emissions on Return on Investment

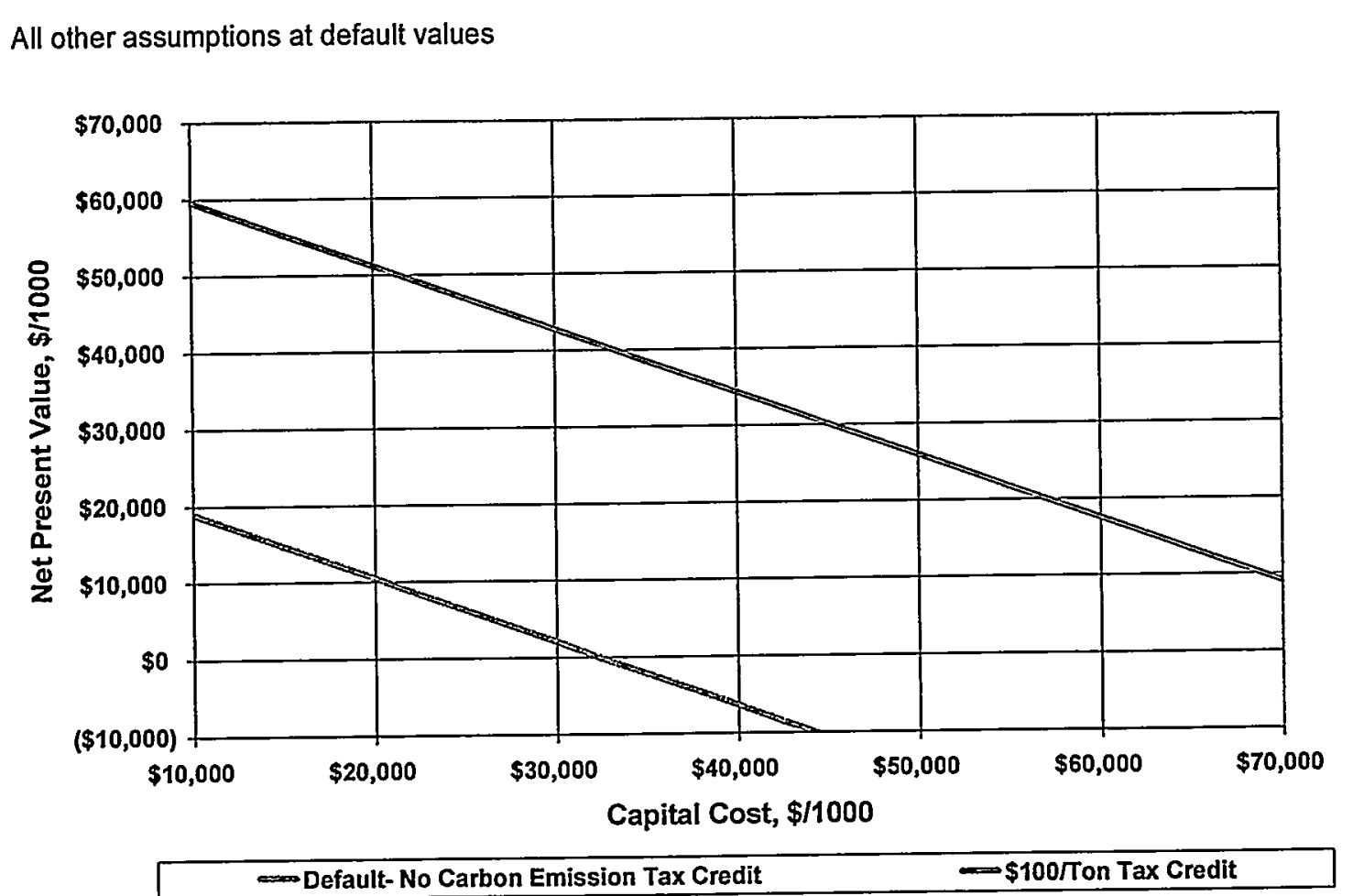

Figure 8-14: Impact of Tax Credits for Avoided Carbon Emissions on Net Present Value 
Reduce Biomass \$10/BDT, \$24 Bbl oil, 1\% Oil Escalation,

Reduced Maintenance Costs

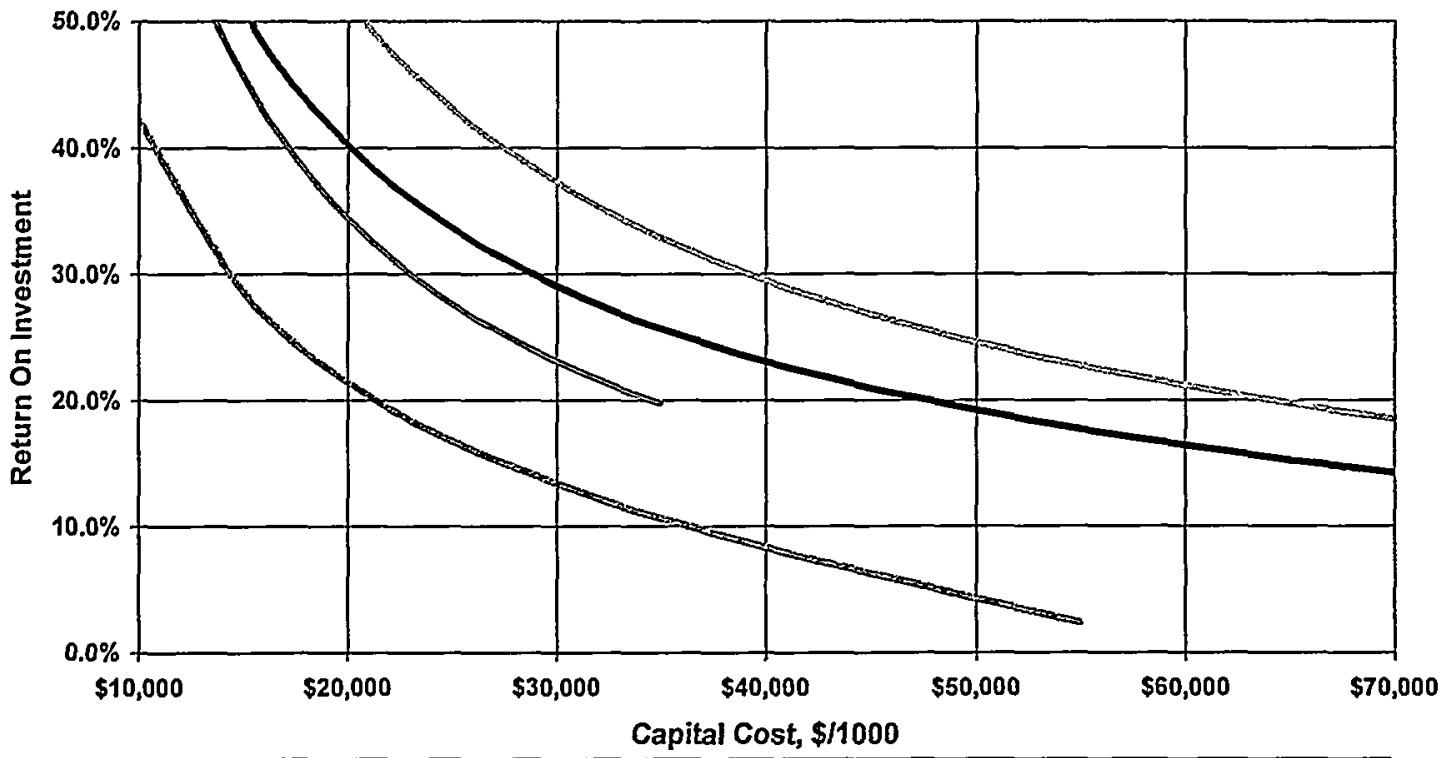

Gasifier- Default Economic Assumptions

—1 P/B Retrofit (no fuel gas tax credit)

- Gasifier (no fuel gas tax credit)

Gasifier-\$1.00/Mbtu Fuel Gas Tax Credit

Figure 8-15: Impact of Favorable Economic Assumptions on Return on Investment

Reduce Biomass \$10/BDT, \$24 Bbl oil, 1\% Oil Escalation,

Reduced Maintenance Costs

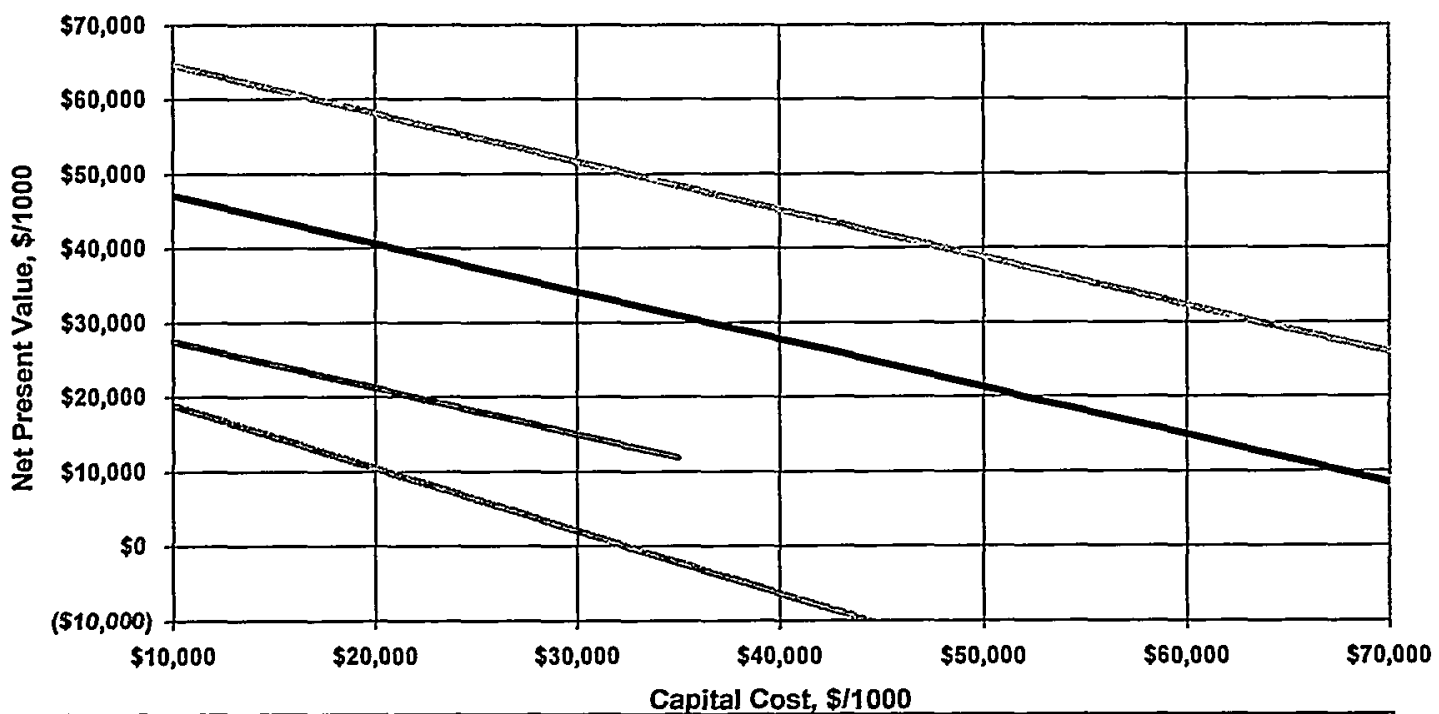

Gasifier- Default Economic Assumptions

-\#1 P/B Retrofit (no fuel gas tax credit)

- Gasifier (no fuel gas tax credit)

Gasifier-\$1.00/Mbtu Fuel Gas Tax Credit

Figure 8-16: Impact of Favorable Economic Assumptions on Net Present Value 
For purposes of this study, a range of ROI "hurdle rate" values from $12 \%$ to $19 \%$ has been defined to represent the minimum threshold required for project economic viability. The low end of the range has been set based on informal discussions with electric power industry independent power project developers. Given a commercially proven technology, this represents a minimum weighted average return to debt and equity project participants that constitutes an economically viable project. The $19 \%$ high end of the range is based on Weyerhaeuser's publicly stated goal of achieving financial performance of at least $19 \%$ return on net assets (RONA) in it's major businesses across the business cycle. Granted, projects with pro forma ROI forecasts of below $19 \%$ ROI can generate contributions greater than 19\% RONA over the life of a project. The 19\% ROI figure has been selected as a benchmark to represent the rate of return above which manufacturing companies may decide investment is warranted. Based on the above range of threshold returns, the Gasifier Project defined for New Bern will support a capital investment in the range of $\$ 22.0$ million to $\$ 31.8$ million using the default economic assumptions.

Figures 8-1 and 8-2 display the sensitivity of economic figures of merit to assumptions about initial oil price and assumed escalation rate. The default values $(\$ 20 / \mathrm{barrel}$ and $0.1 \%$ real escalation) are based on Energy Information Agency forecasts and recent New Bern experience, but recent volatility in oil markets makes even the determination of current trend price somewhat speculative. As seen in these figures, a $\$ 4 / \mathrm{barrel}$ movement in oil price is roughly equivalent to an increase in oil escalation rate from the default value to $2 \%$ (real)/yr. and increases economic value of the Gasifier Project (as measured by NPV) by roughly $\$ 9$ million. Disruptions in oil markets, such as supply-side shocks, would clearly have a major impact on project viability.

As can be observed by examining Figures 8-1 through 8-8, significant deviations from the default values of key fuel and power cost and/or escalation assumptions are needed to bring project economic value into line with the estimated capital investment of nominally $\$ 70$ million. Table $8-3$ below takes each sensitivity parameter individually and back-calculates how far it would have to move in order to generate project ROI's in the threshold range for the "Next Plant" estimated capital cost.

\begin{tabular}{|l|c|c|c|}
\hline \multirow{2}{*}{$\begin{array}{l}\text { Parameter } \\
\# 6 \text { Fuel Oil Escalation, \%/yr. }\end{array}$} & $\ddots$ & \multicolumn{2}{|c|}{$\begin{array}{c}\text { Next Plant Capital } \\
\text { Cost }=\$ 69.7 \mathrm{M}\end{array}$} \\
\cline { 3 - 4 } & Default Value & $\begin{array}{c}\text { Value for } \\
12 \% \text { Rol }\end{array}$ & $\begin{array}{c}\text { Value for } \\
19 \% \text { Rol }\end{array}$ \\
\hline Beginning Oil Price (2000), \$/Bbl. & $0.1 \%$ & $5.8 \%$ & $10.2 \%$ \\
\hline $\begin{array}{l}\text { Capital Cost Support (One Time } \\
\text { Payment), } \$\end{array}$ & N/A & $\$ 38 \mathrm{M}$ & $\$ 48 \mathrm{M}$ \\
\hline Average cost of biomass, \$/BDT & $\$ 18$ & $-\$ 8$ & $-\$ 34$ \\
\hline $\begin{array}{l}\text { Value of displaced purchased } \\
\text { electricity, } \$ / \mathrm{kWh}\end{array}$ & $\$ 0.05$ & $\$ 0.20$ & $\$ 0.33$ \\
\hline
\end{tabular}

Table 8-3: Escalation Factors for Economic Viability 
Table 8-3 suggests it's unlikely that movement of any single fuel and power related parameter will change markedly enough to establish the Gasifier Project economic viability at the New Bern site in the absence of some manner of public policy-related initiative.

Figures 8-9 and 8-10 indicate that given the same ROI "hurdle rate" range and default economic assumptions, the No. 1 Power Boiler Relifing Project will support capital expenditure in the range of $\$ 18.6$ million to $\$ 24.8$ million. This range compares favorably with the estimated project capital of $\$ 22.6$ million and suggests that further investigation regarding the viability of this project is warranted.

Given the much greater fossil fuel displacement which is afforded by the LIVG technology, it is somewhat surprising that the incremental value of the Gasifier Project above the Boiler Relifing Project isn't greater than is observed in Figures 8-9 and 8-10. Given the default assumptions, only $\$ 3.5$ to $\$ 7.0$ million in incremental capital investment is warranted in the threshold ROI range. This is due to several factors:

- The average biomass fuel cost is significantly higher for the gasifier option due to the higher volume of fuel required.

- Parasitic electrical loads are significantly higher for the gasifier case as can be seen from Table 8-1. This further increases the fuel requirements and average biomass fuel cost for the gasifier case.

- Operating manpower requirements for the gasifier case are higher due to increases in process equipment scope and fuel handling requirements.

Figures 8-11 through 8-14 briefly examine the impact of two forms of public policy incentive. Figures 8-11 and 8-12 demonstrate the impact on project economics of a biomass gas tax credit applied for the life of the project at $\$ 1.00 / \mathrm{MB}$ tu of fuel gas (based on higher heating value). The graphics indicate that the fuel gas tax credit by itself would not be sufficient incentive to project implementation given the default assumptions used in this analysis.

Figures 8-13 and 8-14 demonstrate the impact of a hypothetical tax credit for displacement of atmospheric carbon emissions. The tax credit assumes that the gasification project as operated at New Bern would displace carbon emissions from coal and fuel oil combustion by 70,000 tons per year. This figure is the sum of atmospheric carbon emissions estimated from the New Bern base case plus carbon emissions that would be displaced from a bituminous coal-fired power plant generating the same net amount of electricity as the two biomass alternatives (48,355 MWh/yr.). By comparison, 37,000 tons per year of avoided carbon emissions would result from implementation of the No. 1 Power Boiler Relifing Project.

Table 8-4 indicates the levels of several hypothetical public-policy incentives that would be necessary to achieve economic viability for the Gasifier Project as defined for New Bern. Conceptual options include a fuel gas tax credit, a tax credit for avoided atmospheric carbon emissions, or an emissions credit for avoided atmospheric carbon emissions (treated as taxable income). Table 8-4 also shows the range of capital cost subsidy needed to achieve threshold levels of economic return for the "Next Plant" case. Capital support as the only incentive to a Next Plant project would need to be in the range of 54 to 68 percent of the estimated capital cost of the facility to bring economic return into the threshold range. 


\begin{tabular}{|l|c|c|}
\hline \multirow{2}{*}{ Parameter } & \multicolumn{2}{|c|}{ Next Plant Capital Cost $=\$ 69.7 \mathrm{M}$} \\
\cline { 2 - 3 } & Value for 12\% ROI & Value for 19\% ROI \\
\hline $\begin{array}{l}\text { Fuel gas tax credit, \$/MBtu (based on higher } \\
\text { heating value of product gas) }\end{array}$ & $\$ 2.20$ & $\$ 3.79$ \\
\hline $\begin{array}{l}\text { Tax Credit for avoided atmospheric carbon } \\
\text { emissions, \$/ton avoided carbon emission }\end{array}$ & $\$ 94$ & $\$ 163$ \\
\hline $\begin{array}{l}\text { Emission credit (taxable) for avoided } \\
\text { atmospheric carbon emissions, \$/ton avoided } \\
\text { carbon emission }\end{array}$ & $\$ 152$ & $\$ 262$ \\
\hline Capital Cost Support (One Time Payment), \$ & $\$ 38 \mathrm{M}$ & $\$ 48 \mathrm{M}$ \\
\hline
\end{tabular}

Table 8-4: Public Policy Incentives-Levels for New Bern Gasifier Project Economic Viability

A wide variety of "what-if scenarios" could be created to determine what conditions would favor investment in the Gasifier Project at the New Bern site. Figures 8-15 and 8-16 exemplify one such case and makes changes in several important economic parameters to create a scenario more favorable to biomass utilization than is currently envisioned. The following economic assumptions are changed:

- Fuel oil initial price of $\$ 24 / \mathrm{Bbl}$. rather than $\$ 20 / \mathrm{Bbl}$.

- Fuel oil real escalation at $1 \%$ rather than $0.1 \%$

- Average biomass fuel price reduced by $\$ 10 / \mathrm{BDT}$

- Displaced purchased power value at $\$ 0.060 / \mathrm{kWh}$ rather than $\$ 0.050 / \mathrm{kWh}$

- Maintenance costs (expense and capital) at $1.5 \%$ and $1.0 \%$ respectively, rather than $3.5 \%$ and $3.0 \%$

As can be seen from the charts, these changes in assumptions bring the gasifier project returns into the threshold range at the estimated "Next Plant" capital cost. Incremental capital above what can be spent on the boiler retrofit option is also increased. It is interesting to note, however, that economic value above and beyond what is created by the No. 1 Power Boiler Relifing Project is only produced if public policy incentives (such as the fuel gas tax credit) are present. This can be seen by examining Figure 8-16 and is shown in Table 8-5. 


\begin{tabular}{|c|c|c|}
\hline Economic Assumptions & $\begin{array}{c}\text { Biomass Gasifier } \\
\text { Project Net Present } \\
\text { Value-Capital }=\$ 69.7 \mathrm{M}\end{array}$ & $\begin{array}{l}\text { No. } 1 \text { Power Boiler } \\
\text { Retrofit Project Net } \\
\text { Present Value- } \\
\text { Capital = } \$ 22.6 \mathrm{M}\end{array}$ \\
\hline Default values & $-\$ 30 M$ & $\$ 2 M$ \\
\hline $\begin{array}{l}\text { Favorable to biomass: } \\
\text { - } \$ 24 / \mathrm{Bbl} \text {. } \\
\text { - } 1 \% \text { oil escalation } \\
\text { - } \$ 0.06 / \mathrm{kWh} \text { power } \\
\text { - } \$ 8 / \mathrm{BDT} \text { biomass } \\
\text { - } \quad \text { Reduced maintenance expenses and } \\
\text { capital }\end{array}$ & $\$ 9 M$ & $\$ 20 \mathrm{M}$ \\
\hline $\begin{array}{l}\text { Favorable biomass assumptions plus: } \\
\text { - Add } \$ 1.00 / \mathrm{MBtu} \text { fuel gas tax credit } \\
\text { (Gasifier Project Only) }\end{array}$ & $\$ 26 \mathrm{M}$ & $\$ 20 M$ \\
\hline
\end{tabular}

Table 8-5: Economic Value as a Function of Economic Assumptions

\subsubsection{Discussion - Comparison to Biomass Gasification Combined Cycle (BGCC) Technology}

The potential application of biomass gasification combined cycle (BGCC) technology at New Bern was investigated in the previous "New Bern Biomass to Energy Project Phase 1 Feasibility Study" (LOI No. RCA-3-13326) conducted in 1994-95. In that study, BGCC systems were defined for the New Bern site based on both the TPS and Tampella low-Btu gasification technologies. That study concluded that export power prices above $\$ 0.05 / \mathrm{kWh}$ in conjunction with capital subsidies for early implementations of the technology yielded a development path that could lead to commercially viable BGCC combined heat and power systems.

BGCC system configurations have not been proposed for New Bern in the current study, in part because regional power markets do not currently support the necessary power prices to make such a project viable. This and other factors dictated that gasification system configurations in the current study be defined with an emphasis on energy self-sufficiency.

In order to revisit the findings of the "New Bern Biomass to Energy Project Phase 1 Feasibility Study", information from that study has been used to compare the economic performance of a conceptual BGCC system to the economic performance of the biomass projects defined in the current study using the same economic assumptions and evaluation methodology. Heat and material balances for the BGCC technology option are based on the Tampella gasification technology using a steam dryer for fuel preparation. The balances have been adapted to allow direct comparison to the two biomass systems defined in the current study. Key performance parameters are defined in Table 8-6. 


\begin{tabular}{|l|l|}
\hline Description & BGĆ System Value \\
\hline Approximate capital cost (escalated to 2000 dollars) & $\$ 110 \mathrm{M}$ \\
\hline Net BGCC electrical output & $39 \mathrm{MW}$ \\
\hline Net power export & $34 \mathrm{MW}$ \\
\hline Net BGCC system usable thermal export & $190-270 \mathrm{MBtu} / \mathrm{hr}$. \\
\hline Fuel requirement & $319,000 \mathrm{BDT} / \mathrm{yr}$. \\
\hline Average fuel cost & $\$ 20 / \mathrm{BDT}$ \\
\hline
\end{tabular}

Table 8-6: Performance Parameters for BGCC Technology Comparison

The net thermal energy that can be exported from the BGCC system is stated as a range, depending on how much useful heat is recovered from the steam dryer exhaust stream. The mill's non-recovery thermal requirements can be met within the range stated in Table 8-6, although how dryer waste heat would be integrated to satisfy thermal process demands at New Bern has not been specifically determined. The average fuel cost displayed in Table 8-6 is based on biomass fuel supply data presented in Section 2 of this report. Economic assumptions used are the same as for the biomass projects defined in the current study. Economic performance of the BGCC system is compared to the biomass options of the current study in Figures 8-17 and 8-18 below.

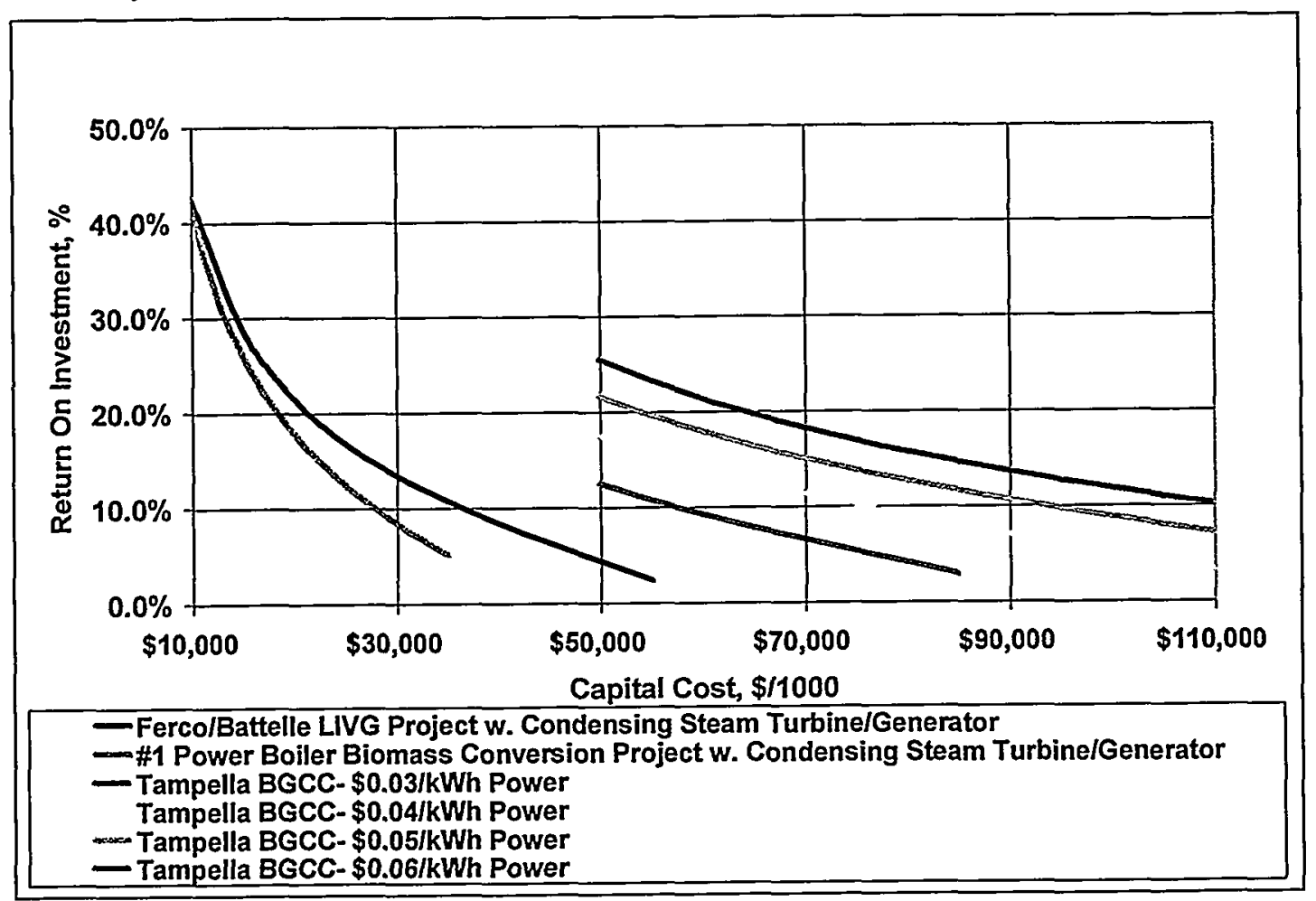

Figure 8-17: New Bern DOE Study Options vs. Tampella BGCC/LOI Study - Return on Investment 


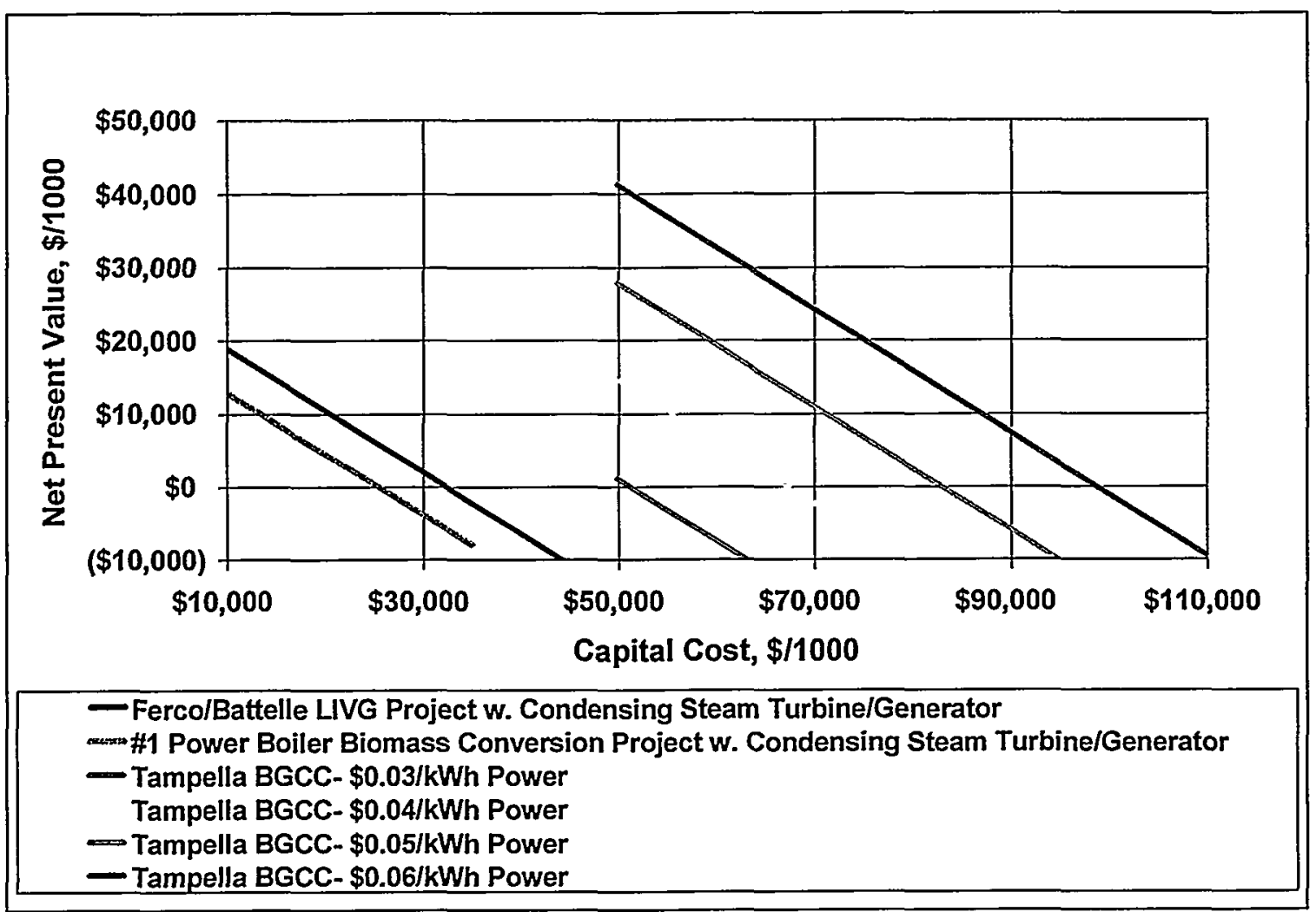

Figure 8-18: New Bern DOE Options vs. Tampella BGCC - Net Present Value

Again using an economic return threshold of 12-19\% ROI, the BGCC option will support capital investment in the ranges shown below in Table 8-7 as a function of export power price.

\begin{tabular}{|l|c|c|c|}
\hline $\begin{array}{l}\text { Case Description } \\
\text { Estimated } \\
\text { Capital }\end{array}$ & $\begin{array}{c}\text { Supportable } \\
\text { Capital at } \\
19 \% \text { Rol }\end{array}$ & $\begin{array}{c}\text { Supportable } \\
\text { Capital at } \\
12 \% \text { ROI }\end{array}$ \\
\hline $\begin{array}{l}\text { No. 1 Power Boiler Relifing Project with } \\
\text { Condensing Steam Turbine }\end{array}$ & $\$ 23 \mathrm{M}$ & $\$ 19 \mathrm{M}$ & $\$ 25 \mathrm{M}$ \\
\hline $\begin{array}{l}\text { FERCO/Battelle LIVG Project with } \\
\text { Condensing Steam Turbine }\end{array}$ & $\$ 70 \mathrm{M}$ & $\$ 22 \mathrm{M}$ & $\$ 32 \mathrm{M}$ \\
\hline $\begin{array}{l}\text { BGCC System with power sales at } \\
\$ 0.04 / \mathrm{kWh}\end{array}$ & $\$ 110 \mathrm{M}$ & $\$ 46 \mathrm{M}$ & $\$ 67 \mathrm{M}$ \\
\hline $\begin{array}{l}\text { BGCC System with power sales at } \\
\$ 0.05 / \mathrm{kWh}\end{array}$ & $\$ 110 \mathrm{M}$ & $\$ 57 \mathrm{M}$ & $\$ 83 \mathrm{M}$ \\
\hline $\begin{array}{l}\text { BGCC System with power sales at } \\
\$ 0.06 / \mathrm{kWh}\end{array}$ & $\$ 110 \mathrm{M}$ & $\$ 67 \mathrm{M}$ & $\$ 99 \mathrm{M}$ \\
\hline
\end{tabular}

Table 8-7: Supportable Capital Summary for New Bern Biomass Options

These results are consistent with findings of the New Bern Biomass to Energy Feasibility Study, indicating that a power price of $\$ 0.05 / \mathrm{kWh}$ or more would be needed to attain project viability. 


\subsection{Conclusions: New Bern Gasification Project Economic Analysis}

The economic analysis of the Gasification Project option for New Bern indicates that, given default values of key economic assumptions, project viability would require significant external subsidy to the project in one form or another. Sensitivity analysis of key economic assumptions indicates that favorable shifts in several key economic assumptions would have to occur in concert to ensure the Gasifier Project's viability. Economic value creation above what is possible with conventional technology occurs only when favorable economic assumptions are combined with public policy incentives geared toward expanding biomass fuels utilization.

It is important to note that these conclusions are highly specific to the New Bern site. Key factors about the New Bern situation decrease the value of the gasification technology below what its value could be at other implementation sites. These factors include:

Biomass fuel market characteristics - Weighted average biomass fuel cost is $\sim 18 / \mathrm{BDT}$ at the volume required by the Gasifier Project. This is higher than may be the case in other regions-in part due to the local presence of a large biomass-fueled independent power producer (the $45 \mathrm{MW}$ Craven County Wood Energy Project). In addition, the New Bern mill currently has a reasonably good market for selling its manufacturing residual. Economic return of both biomass projects suffer from the fact that implementation of either technology alternative means loss of fuel revenues to the site from fuel sales. This positive situation with respect to residual sales was uncertain when the project was conceived in 1996.

Presence of a boiler suitable for biomass firing - The conventional technology alternative in this case is based on retrofitting an existing boiler rather than installing a new biomass-fired boiler. The conventional technology option would look much less attractive were a new biomass-fired boiler required.

Low emphasis on electric power production - The New Bern situation does not currently lend itself to maximization of electric power production or the export of baseloaded electric power. A key prospective feature of the LIVG technology is its ability to use biomass fuels in combined-cycle power systems. This alternative was not considered in the current study, largely due to power market conditions. As shown in the BGCC technology comparison for New Bern (Figures 8-17 and 8-18; Tables 8-6 and 8-7) higher power values are necessary to support a BGCC-based approach. At the conception of the project, a resolved and attractive power market was anticipated.

Little opportunity for avoided capital expenditure - Biomass fuel conversion projects are sometimes driven, in part, by the need to invest significant capital in the existing facility in order to maintain the status quo. Examples would include capital expenditure (and associated operating costs) to mitigate $\mathrm{SO}_{2}$ or NOx emissions. This situation does not currently exist at New Bern. In 1996, the need for a new power boiler was imminent. In fact, one was purchased, which removed the opportunity for avoided capital to be factored into the gasification alternative. Had the project been able to move more rapidly, this might not have been the case. 
Favorable fossil fuel economic forecast - Assumptions for current fossil fuel cost and real escalation rate for New Bern are lower than may be the case for other localities. Comparison to a base case situation featuring natural gas as the default fuel with higher escalation assumptions would yield more favorable economics for a gasification-based energy project. In 1996, a 3.1\% oil price escalation was anticipated. This is significantly higher than the consensus belief today.

Given the significant changes in the New Bern mill operating parameters and external factors impacting the project, it was realized in late 1998 that the likelihood of an early implementation at New Bern was low. With the DOE's concurrence, a scope change redirected the project to focus on opportunities for improving the capital and operating economics and defining the characteristics of a more viable implementation site. As a result, a generic gasification island was developed. Section 9 addresses the design and economic factors to be considered for selecting a site that will provide sustainable economics. 


\section{Section 9}

\section{Public Policy \&}

Sustainable Economic

Considerations 


\subsection{Public Policy \& Sustainable Economic Considerations}

\subsection{Approach}

As stated in the last section, the LIVG process economic performance at New Bern is negatively impacted by several factors. Key among these factors is that the biomass fuel market in the area is currently quite healthy compared to some other regions in North America, resulting in reduced spread between biomass and fossil fuel pricing. The existence of a power boiler on site that can be converted to biomass firing gives the mill a less capital intensive option for firing biomass than would be available to many other industrial sites. The current New Bern situation offers little opportunity for a gasifier project to displace other capital that would be necessary to sustain plant operation. In addition, although there is opportunity to displace a purchased electric load of modest size, the electric power market does not lend itself to development of base load power generation for sale to the power grid. Finally, the price and escalation assumptions used for future \#6 oil utilization are not as favorable to biomass alternatives as pricing assumptions would be for a site firing natural gas. Many of these elements are quite different now than when the project was conceived in 1996.

The intent of presenting a "Generic" look at economics of the LIVG process is to provide potential users of the technology with a starting point for understanding what conditions favor its use. To that end, economic performance projections are presented for a broader array of biomass and fossil fuel costs than in the previous section. In addition, projections are added for different levels of capacity utilization. As before, economic figures of merit are displayed as a function of capital employed. By incrementing the Nth Plant Design Generic Application Capital Cost Estimate (see Table 5-6) to better reflect a given site's situation, a feasibility-level capital cost can be estimated for a specific user's situation at the same fuel processing capability (790 BDT/day). Appropriate scaling adjustments would need to be made by the reader for systems at other sizes.

The "Generic" assessment of economic viability of the FERCO-LIVG process is conducted using the same basic methodology used to evaluate the New Bern projects. A base case and LIVG project case are defined as was done for New Bern. Assumptions have been changed to reflect a typical industrial fossil fuel use situation where biomass retrofit may be considered. Key elements of the analysis are highlighted below:

- LIVG process performance assumptions remain unchanged.

- LIVG product gas substitutes for fossil fuel at the host site at equal thermal efficiency.

- Steam from the product gas HRSG and surplus waste steam from the fuel dryer are valued at the value of steam generated from fossil fuel in the base case. This implies there is a process steam load large enough to consume at least this amount of steam on a year-around basis.

- The host site operates on a 355 day, 24 hour/day basis.

- Consistent with the Generic capital cost estimate (Table 5-6), no condensing steam turbine is included. 
- There is no credit for "avoided capital" which must be spent in the base case. Readers can examine this impact by adjusting the capital required for their site to reflect the impact of avoided capital spending.

Potentially, the most promising commercial application of the LIVG process is in providing fuel to combustion turbines in combined cycle application. The above approach was chosen in order to separate the economics of fuel substitution from the economics of power generation. Thus, as long as the "export steam product" of the LIVG process can be used, this comparison is indifferent to whether the product gas fires a boiler, a combustion turbine, or a direct-fired process heater. The key factor is that the medium-Btu product gas from the LIVG process be directly substitutable for the fuel currently in use. This analysis assumes the fuel utilization efficiencies are the same, although minor differences in utilization efficiency will not have material impact on the results and conclusions drawn from the analysis. Limitations of this approach are that it does not recognize any synergy or economic value that that may result from combining biomass fuel utilization and export power production (e.g., potential "green power applications").

As in the New Bern-specific economic case, results of the economic analysis are presented as a function of capital requirement in order to focus on what level of capital expenditure can be supported by the economic benefits provided by the project. This analysis does not differentiate "Next Plant" from "Nth Plant" in process performance from either a thermal or reliability/operability perspective; the LIVG process is defined to have a high level of thermal efficiency and is assumed to operate with a level of reliability that is normally expected of fully commercial process systems in continuous process industries. Therefore, evaluation of economic results at the "Generic Plant Capital Cost" of $\$ 50.0 \mathrm{M}$ (see table 5-6) allows inferences to be drawn regarding economic viability of Nth plant applications of the process.

\subsection{Overview of Alternatives}

Table 9-1 below summarizes the major impacts of the generic LIVG project on the fuel and purchased power requirements of the host site. As seen in the table, the only electrical cost impact to the project is from the electrical load of the new gasification island. Appropriate parameters have been zeroed out so that the table shows only incremental values for the key parameters.

\begin{tabular}{|c|c|c|}
\hline $\begin{array}{l}\text { Parameter } \\
\end{array}$ & $\begin{array}{l}\text { Base Case: Generic } \\
\text { Fossil Fuel User }\end{array}$ & LIVG Process Fetrofit \\
\hline Capital Cost & 0 & $\$ 50.0$ million (Nth plant) \\
\hline Fossil Fuel Use & 546.3 MBtu/hr. & $0 \mathrm{MBtu} / \mathrm{hr}$. \\
\hline Capacity Utilization & N/A & $80 \%$ \\
\hline Disposition of Site Fuel Residuals & N/A & N/A \\
\hline Purchased Biomass Fuel & None & 33.41 BDT/hr. (full load) \\
\hline Purchased Electric Power & N/A & $\begin{array}{l}3,990 \mathrm{~kW} \text { incremental to base } \\
\text { case (gasification island load) }\end{array}$ \\
\hline
\end{tabular}

Table 9-1: Overview of the Generic LIVG Project 


\subsection{Analytical Method, Assumptions and Key Inputs}

As in the New Bern case, the net economic benefits the generic LIVG retrofit project are reduced to an after-tax cash flow stream. Economic assumptions are the same as for the New Bern case with qualifications as follows:

Investment tax credits (North Carolina-specific) - Retained at 15\% for biomass projects. Although this tax credit structure is North Carolina-specific, it was retained for the generic case in that other states may have measures which encourage increased utilization of renewable fuels. The relative importance of this factor will be investigated as part of the project sensitivity analysis.

Depreciation schedules \& tax credits - Five year double declining balance (DDB) depreciation was used in the New Bern analysis whereas fifteen year DDB is more typical for industrial equipment. This preferential treatment for biomass options was retained for the generic case. The importance of this assumption is examined through sensitivity analysis.

Project residual values - Based on after-tax cash flow in last year of operation

The operating cost/benefit impacts of the generic LIVG project are considered in the following cost categories:

Biomass fuel cost - Biomass fuels similar in specifications to those found in the New Bern case are purchased on the open market. The analysis focuses on what biomass costs are required for project viability. It is assumed that average moisture of fuel into the LIVG process is $50 \%$, wet basis. Biomass fuel prices are escalated at the nominal rate of inflation (zero percent real price escalation). The default value of biomass fuels used when investigating the sensitivity of other key economic assumptions is $\$ 10 / \mathrm{BDT}$, half the average biomass cost used in the New Bern cases. This is an arbitrary figure intended to reflect a host site fuel supply which is favorable to new biomass energy projects. Biomass fuel cost sensitivity is investigated from $\$ 0 / \mathrm{BDT}$ to $\$ 30 / \mathrm{BDT}$ (roughly equivalent to typical coal pricing).

Fossil fuel cost - Biomass fuel utilization displaces fossil fuel in host site users at the same fuel utilization efficiency as in the base case. A default value of $\$ 3.00 / \mathrm{MBtu}$ is used for fossil fuel with fossil fuel price as a major parameter investigated in economic sensitivity analysis. This value is midway between EIA average year 2000 values cited for residual oil and natural gas. Fossil fuel price real escalation is assumed at a default value of 1.0\%/yr., in line with EIA "Reference Case" projections for natural gas pricing for industrial users . A thermal credit for surplus dryer exhaust steam is given as in the New Bern project case. Fossil fuel use is assumed as "back-up fuel" $4 \%$ of operating time to cover biomass fuel system operating issues.

Purchased electric power - Purchased power escalation assumptions are the same as used in the New Bern cases. Gasifier island electrical load is costed at $\$ 0.044 / \mathrm{kWh}$ consistent with EIA average industrial electric power prices.

Operating labor - Labor for the biomass alternatives is added based on the staffing requirements estimated in Section 7.6.1. Fully loaded labor rates of $\$ 22 / \mathrm{hr}$. are used and are assumed to escalate at the nominal inflation rate. 
Maintenance costs - Expensed maintenance labor and materials are estimated to be $3.5 \%$ of initial capital per year escalated at the nominal inflation rate. Maintenance capital is added at $3 \% / y r$. These values are based on pulp and paper industry experience and data.

Boiler Feedwater, Waste Water Treatment, Cooling Water and Miscellaneous Chemicals/Operating Supplies - Allowances are made on a case-specific basis and escalated at the nominal inflation rate.

\subsection{Results and Discussion: Generic LIVG Process Economics}

Results of the economic analysis are shown in the following paired graphics, Figures 9-1 through 9-16. As in the New Bern cases, when an acceptable ROI "hurdle rate" is specified, the figures allow estimation of how much capital can be spent to capture the economic benefits provided by the project. The economic value of the project can then be estimated from the accompanying NPV graphic. In all figures, the green trend lines represent the use of the "default" assumptions for all parameters (except capital cost).

The following sensitivities are investigated independently:

- Oil and biomass price sensitivity: Figures 9-1 through 9-8

- LIVG system capacity utilization: Figures 9-9 and 9-10

The impact of current public policy incentives for biomass utilization is examined in Figures 9-11 and 9-12 where economic figures of merit are compared with and without preferences applied to biomass projects in the area of investment tax credit and depreciation schedule. The potential impact of public policy-based incentives to encourage expanded use of biomass fuels is also investigated. Figures 9-13 and 9-14 demonstrate how LIVG project ROI and NPV are affected by a $\$ 1.00 / \mathrm{MBtu}$ biomass fuel gas tax credit. Figures 9-15 and 9-16 demonstrate the potential impact of tax credits associated with reduction of atmospheric carbon emissions assuming that biomass substitution (from renewable sources) for fossil fuels would qualify for such tax credits.

\subsubsection{Economic Assumptions}

Table 9-2 summarizes the default assumptions used in this analysis and embodied in Figures 9-1 through 9-16. 


\begin{tabular}{|c|c|}
\hline Pazameter & Default Value \\
\hline General inflation rate, $\%$ & $2.5 \%$ \\
\hline Discount rate, \% & $12 \%$ \\
\hline Income tax rate, $\%$ & $38 \%$ \\
\hline Investment tax credit & $\begin{array}{l}15 \% \text { for biomass projects } \\
5 \% \text { for other capital projects }\end{array}$ \\
\hline Tax depreciation & $\begin{array}{l}5 \text { yr. double declining balance for biomass projects } \\
15 \text { yr. double declining balance for other capital projects }\end{array}$ \\
\hline Project life & 25 years \\
\hline Displaced fossil fuel, $\$ / \mathrm{MBtu}$. & $\$ 3.00$ \\
\hline Real escalation rate - fossil fuel, $\%$ & $1.0 \%$ \\
\hline Average Power Cost $-\not / \mathrm{kWh}$ & $4.4 \phi$ \\
\hline $\begin{array}{l}\text { Real escalation rate - purchased electric } \\
\text { power }\end{array}$ & $\begin{array}{ll}2000-2005: & -0.5 \% / y r \\
2006-2010 & -1.0 \% / y r \\
2011-2015 & +0.7 \% / y r \\
2016 \text { to end } & -0.3 \% / y r\end{array}$ \\
\hline Average biomass price, $\$ / \mathrm{BDT}$ & $\$ 10$ (at Gasifier Project volume) \\
\hline $\begin{array}{l}\text { Maintenance capital requirement, \% of } \\
\text { capital/yr. }\end{array}$ & $3.0 \%$ \\
\hline $\begin{array}{l}\text { Maintenance materials and labor, } \% \text { of } \\
\text { capital/yr. }\end{array}$ & $3.5 \%$ \\
\hline Capacity Factors (based on 365 day year) & $\begin{array}{l}\text { Mill- 92\% } \\
\text { Gasifier Project- } 88 \%\end{array}$ \\
\hline Start Up Dates & Gasifier Project- 2003 \\
\hline Capital Spending Period & Gasifier Project- Two Years \\
\hline
\end{tabular}

Table 9-2: Summary of Default Economic Assumptions (Generic Case) 
Free Biomass; other assumptions at default values

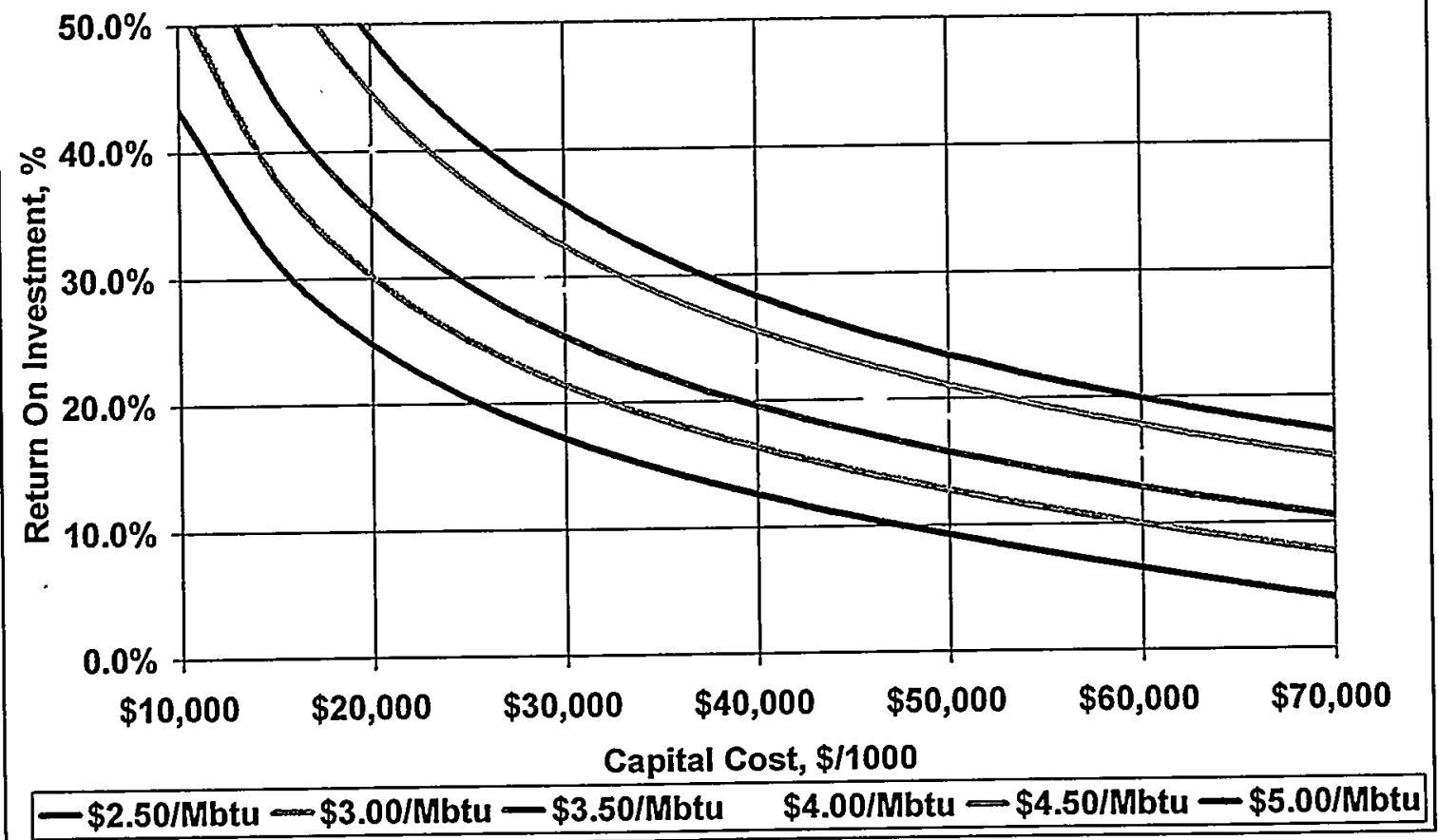

Figure 9-1: Impact of Fossil Fuel Cost on Return on Investment

Free Biomass; other assumptions at default values

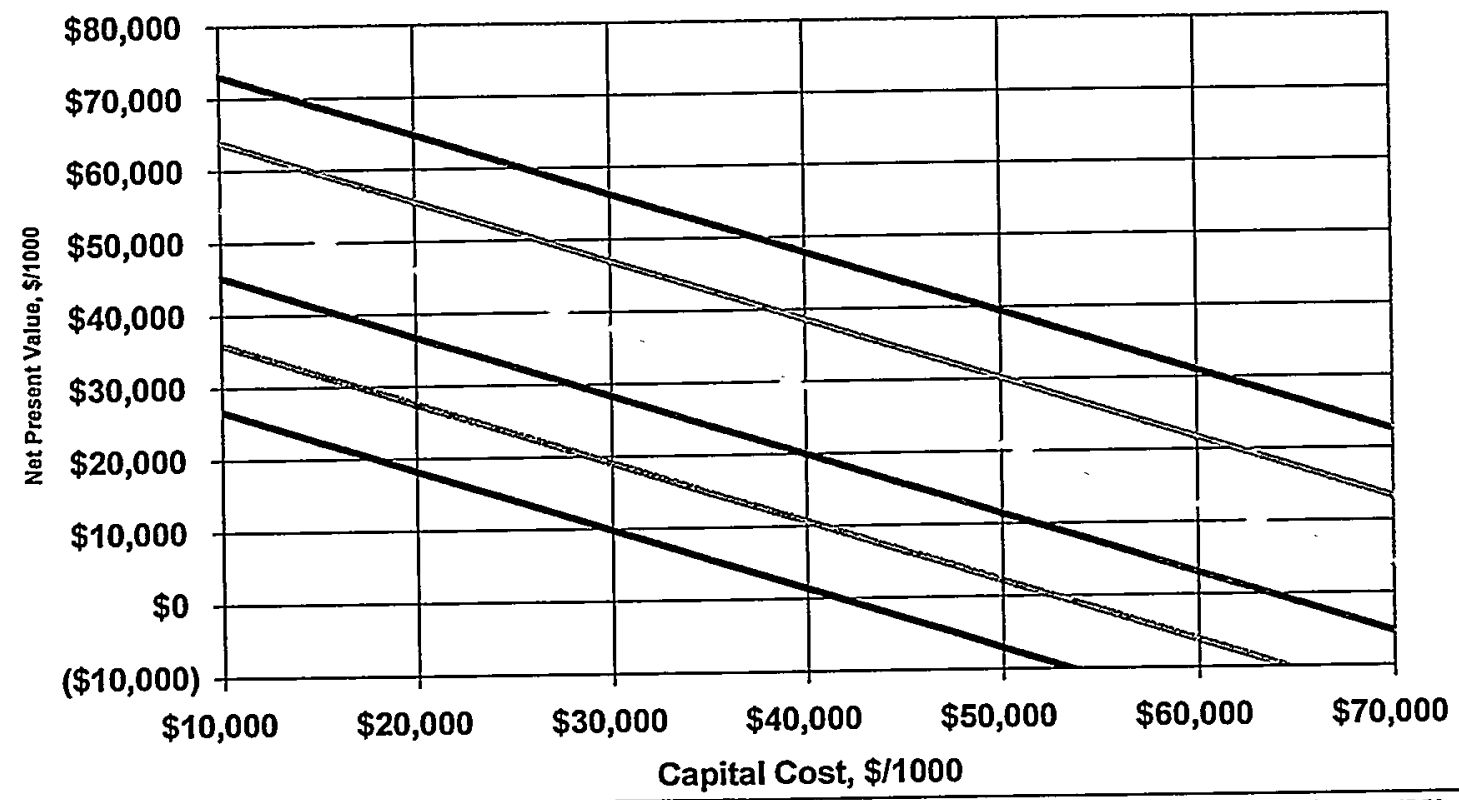

$=\$ 2.50 / \mathrm{Mbtu}=\$ 3.00 / \mathrm{Mbtu}-\$ 3.50 / \mathrm{Mbtu} \quad \$ 4.00 / \mathrm{Mbtu}=\$ 4.50 / \mathrm{Mbtu}=\$ 5.00 / \mathrm{Mbtu}$

Figure 9-2: Impact of Fuel Costs on Net Present Value 


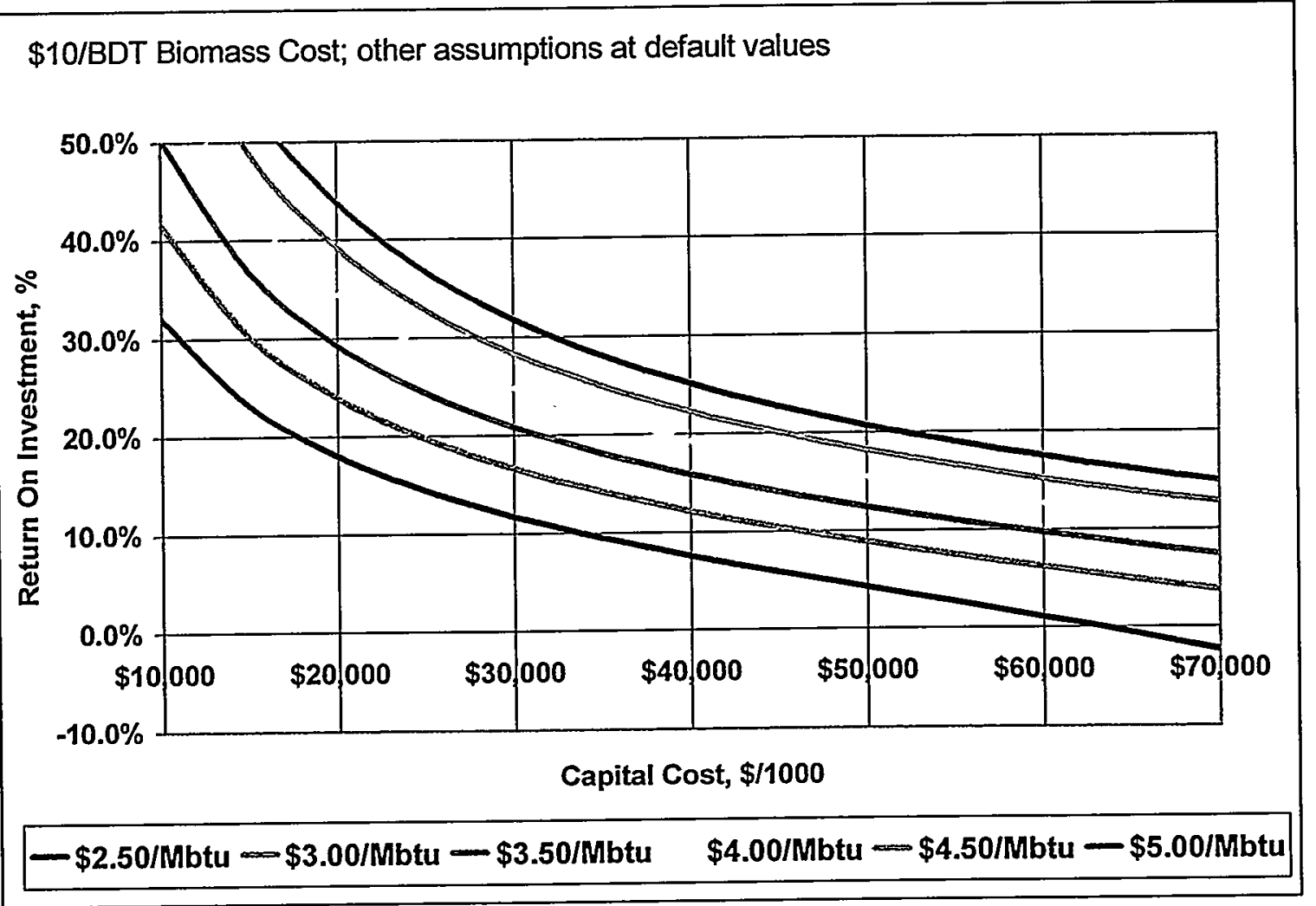

Figure 9-3: Impact of Fossil Fuel Cost on Return on Investment

\$10/BDT Biomass Cost; other assumptions at default values

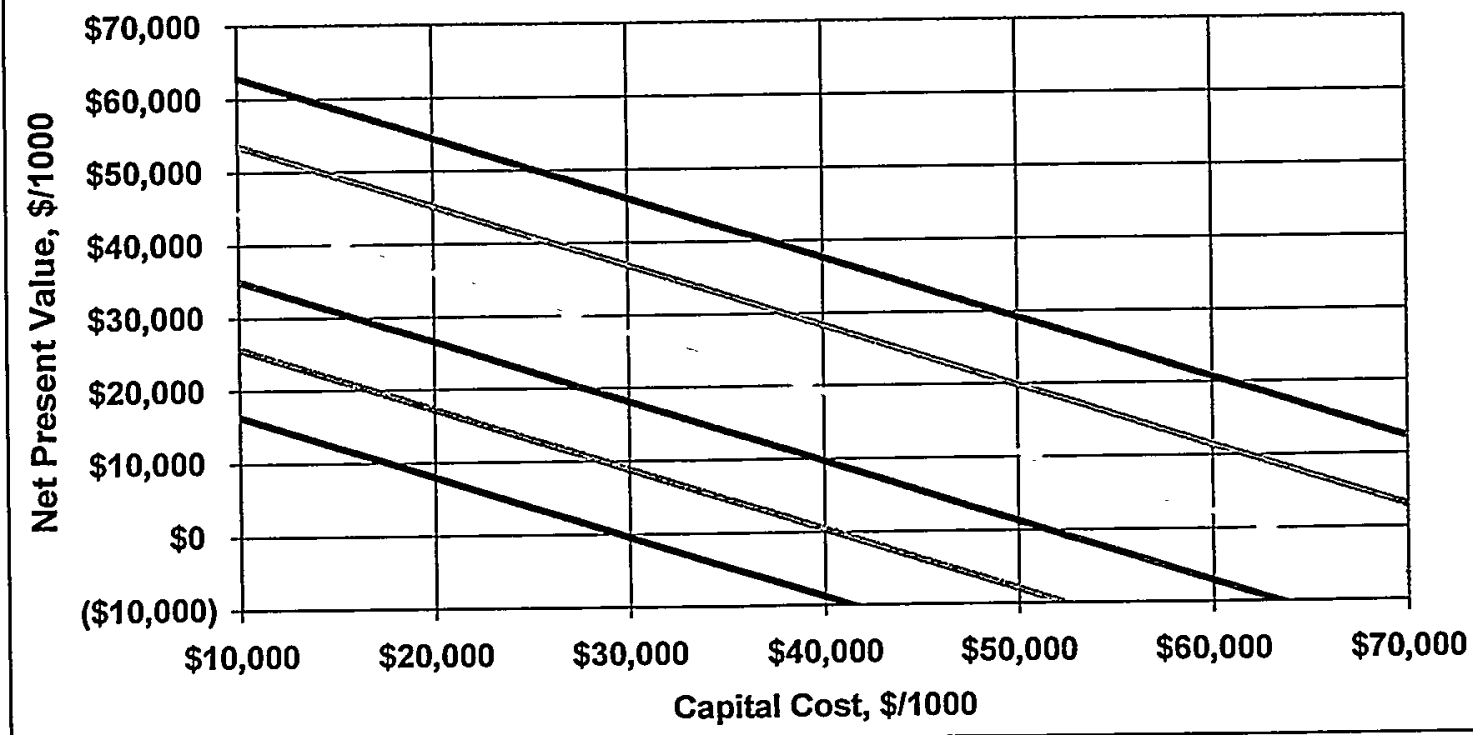

$-\$ 2.50 / \mathrm{Mbtu}=\$ 3.00 / \mathrm{Mbtu}-\$ 3.50 / \mathrm{Mbtu} \quad \$ 4.00 / \mathrm{Mbtu}-\$ 4.50 / \mathrm{Mbtu}-\$ 5.00 / \mathrm{Mbtu}$

Figure 9-4: Impact of Fuel Costs on Net Present Value 
\$20/BDT Biomass Cost; other assumptions at default values

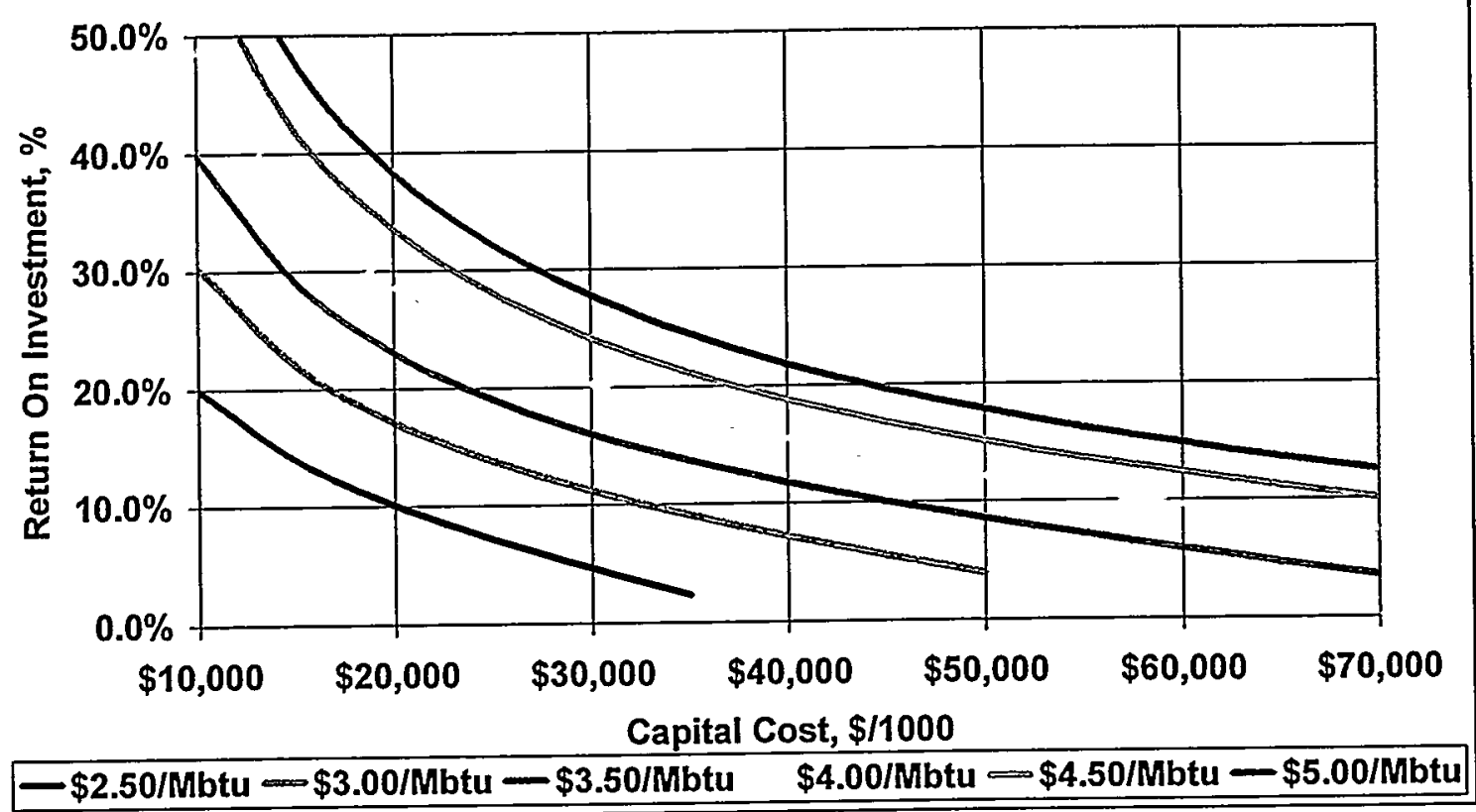

Figure 9-5: Impact of Fossil Fuel Cost on Return on Investment

\$20/BDT Biomass Cost; other assumptions at default values

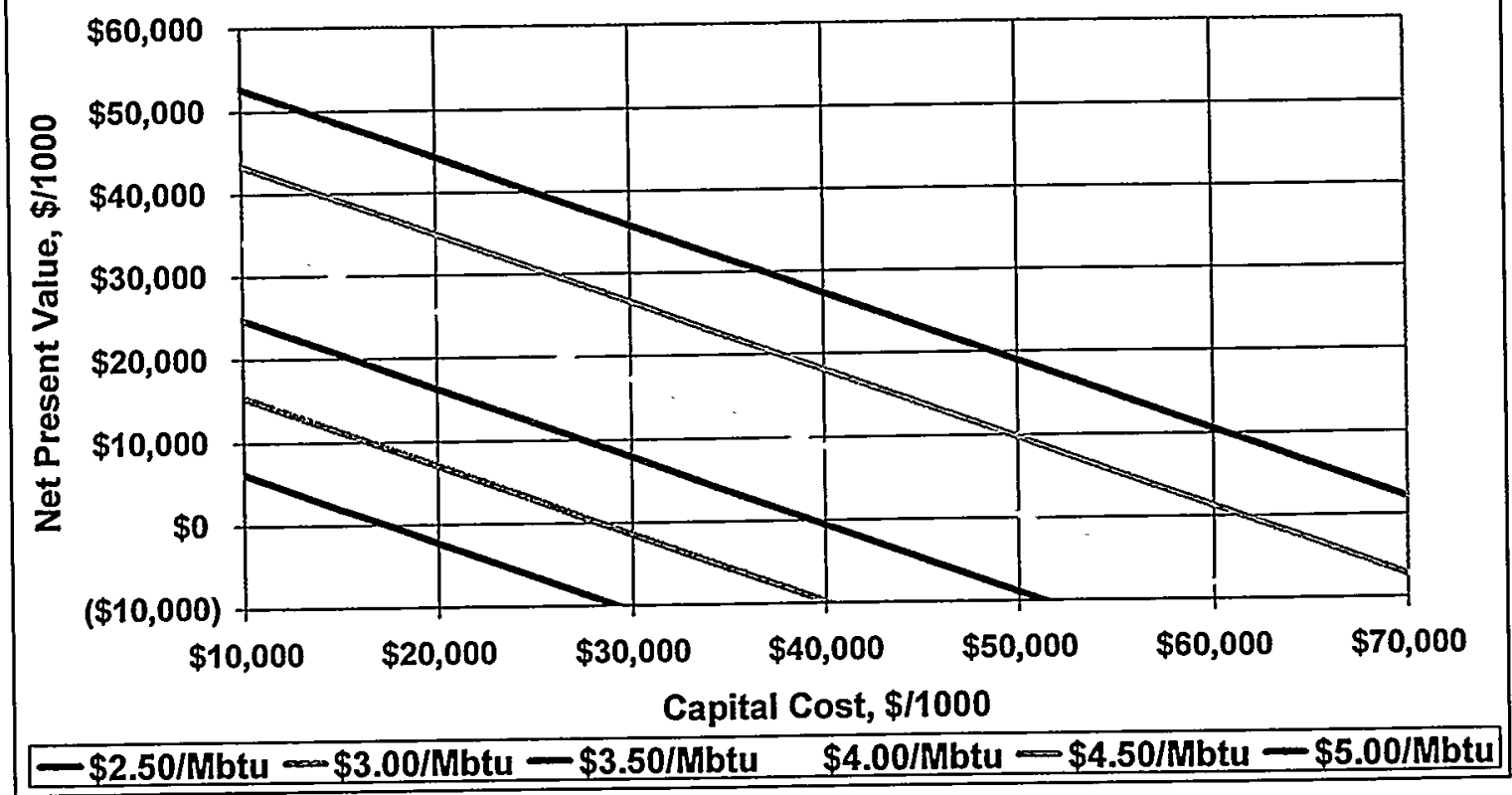

Figure 9-6: Impact of Fuel Costs on Net Present Value 
\$30/BDT Biomass Cost; other assumptions at default values

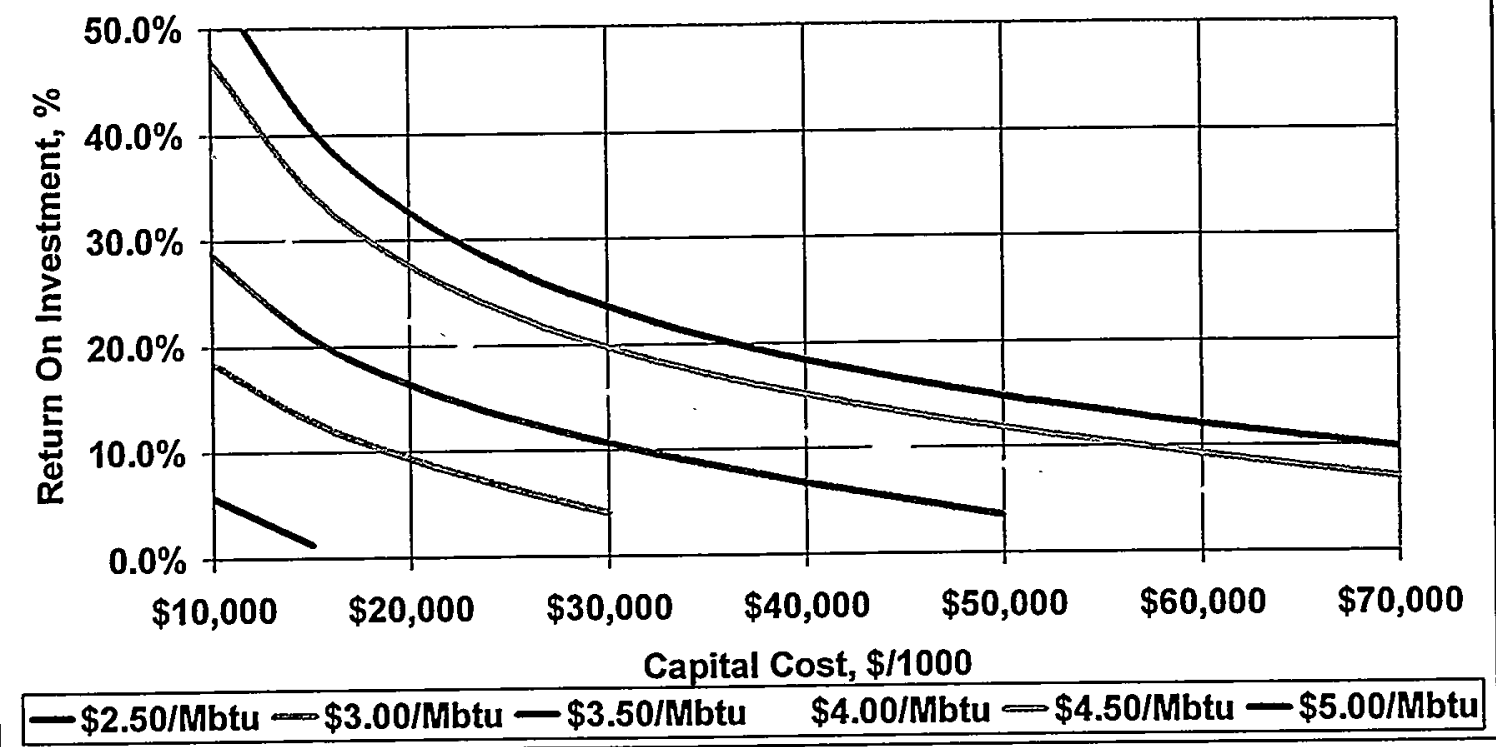

Figure 9-7: Impact of Fossil Fuel Cost on Return on Investment

\$30/BDT Biomass Cost; other assumptions at default values

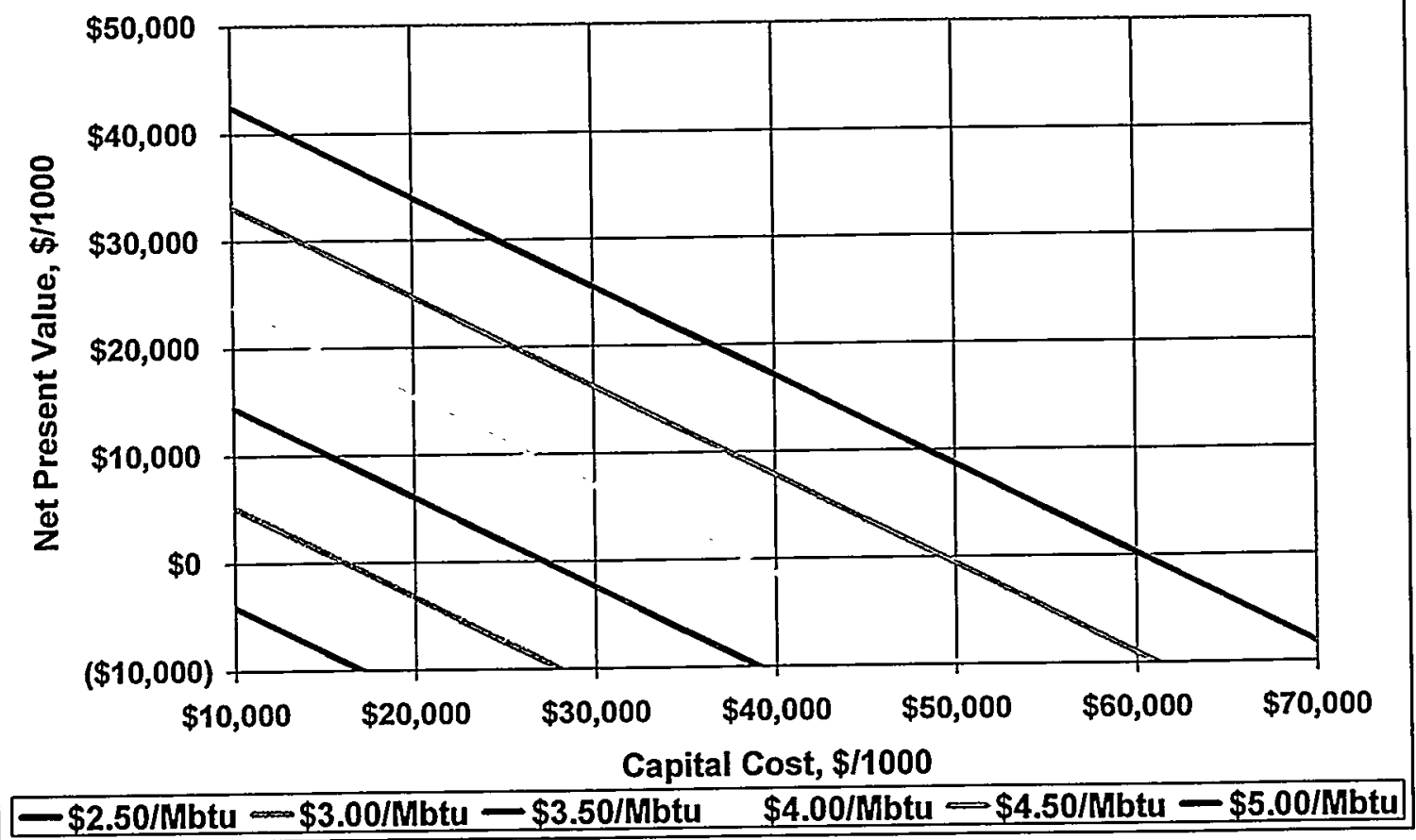

Figure 9-8: Impact of Fuel Costs on Net Present Value 


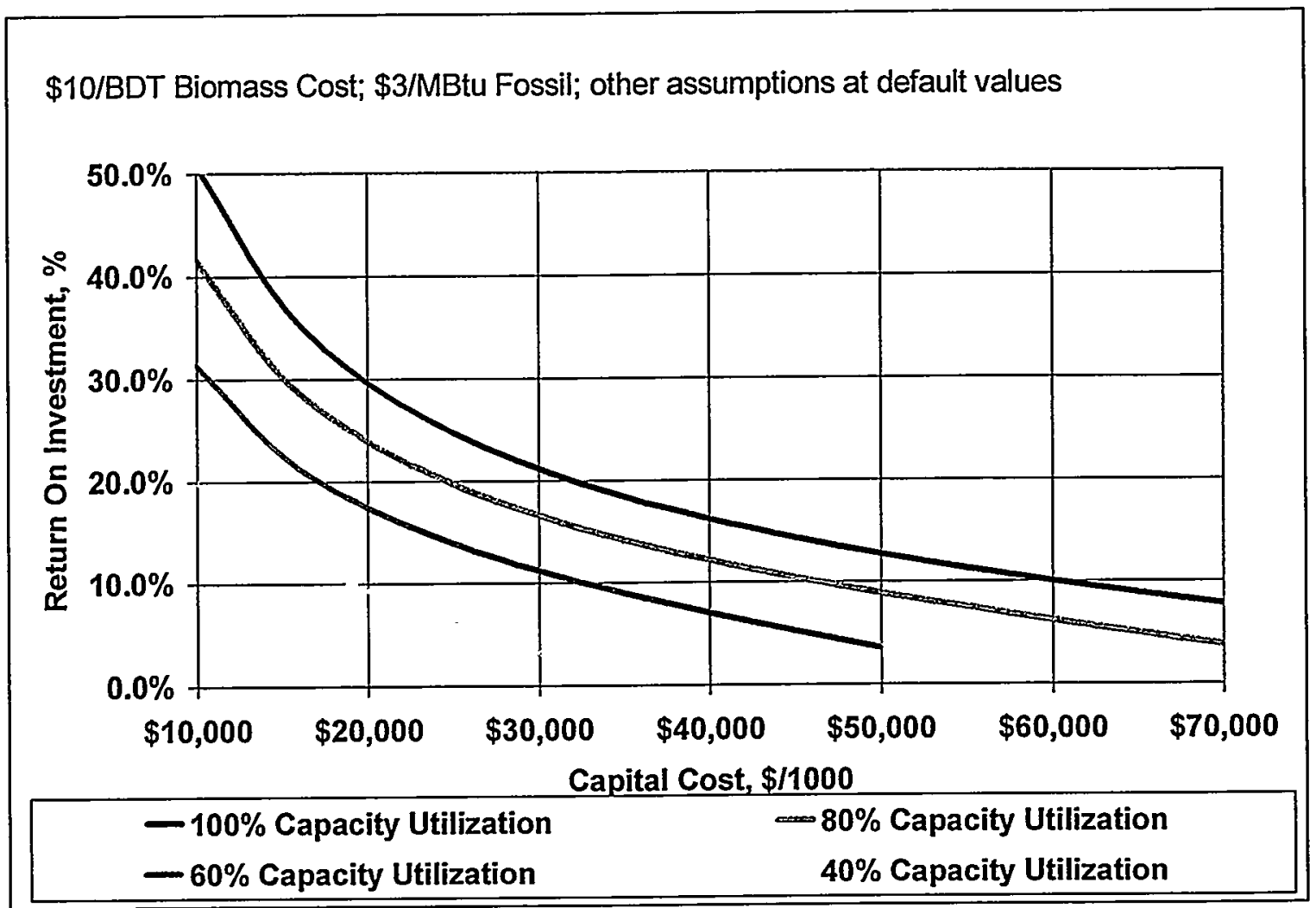

Figure 9-9: Impact of Capacity Utilization on Return on Investment

\$10/BDT Biomass Cost; \$3/MBtu Fossil; other assumptions at default values

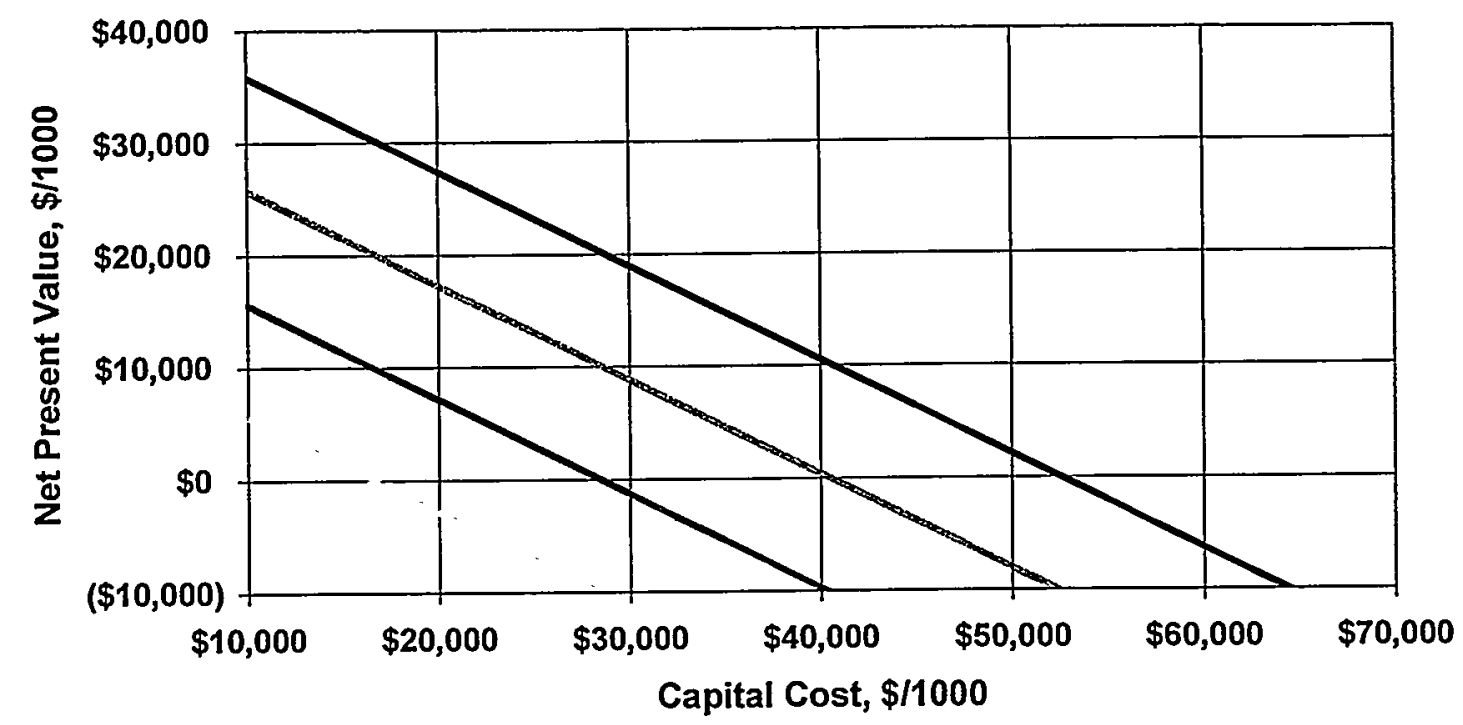

$-100 \%$ Capacity Utilization $-80 \%$ Capacity Utilization $-60 \%$ Capacity Utilization $40 \%$ Capacity Utilization

Figure 9-10: Impact of Capacity Utilization on Net Present Value 
All other assumptions at default values

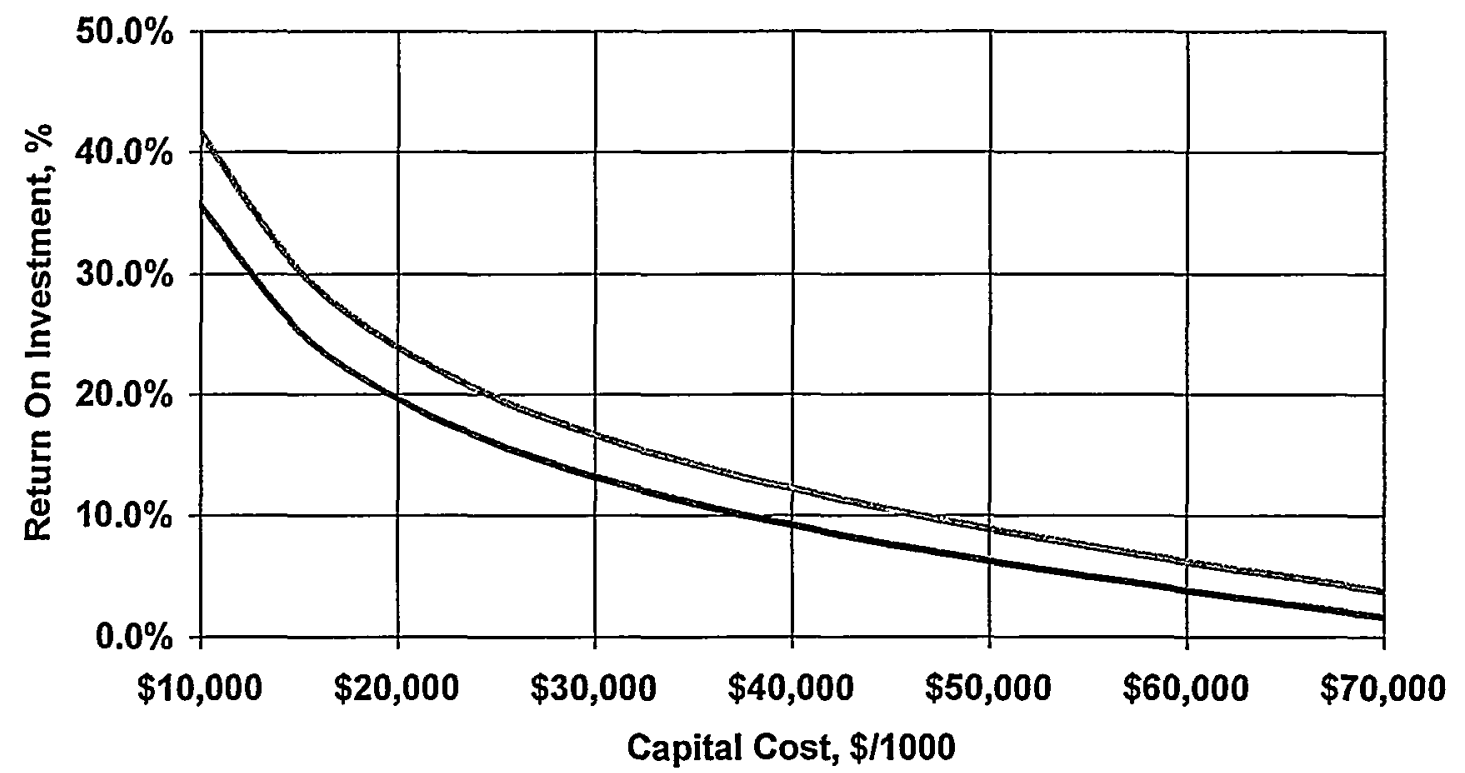

arma Default Economic Assumptions- 5 Year DDB Depreciation, 15\% Investment Tax Credit

- 15 Year DDB Depreciation, 5\% Investment Tax Credit

Figure 9-11: Impact of Preferential Tax Treatment on Return on Investment

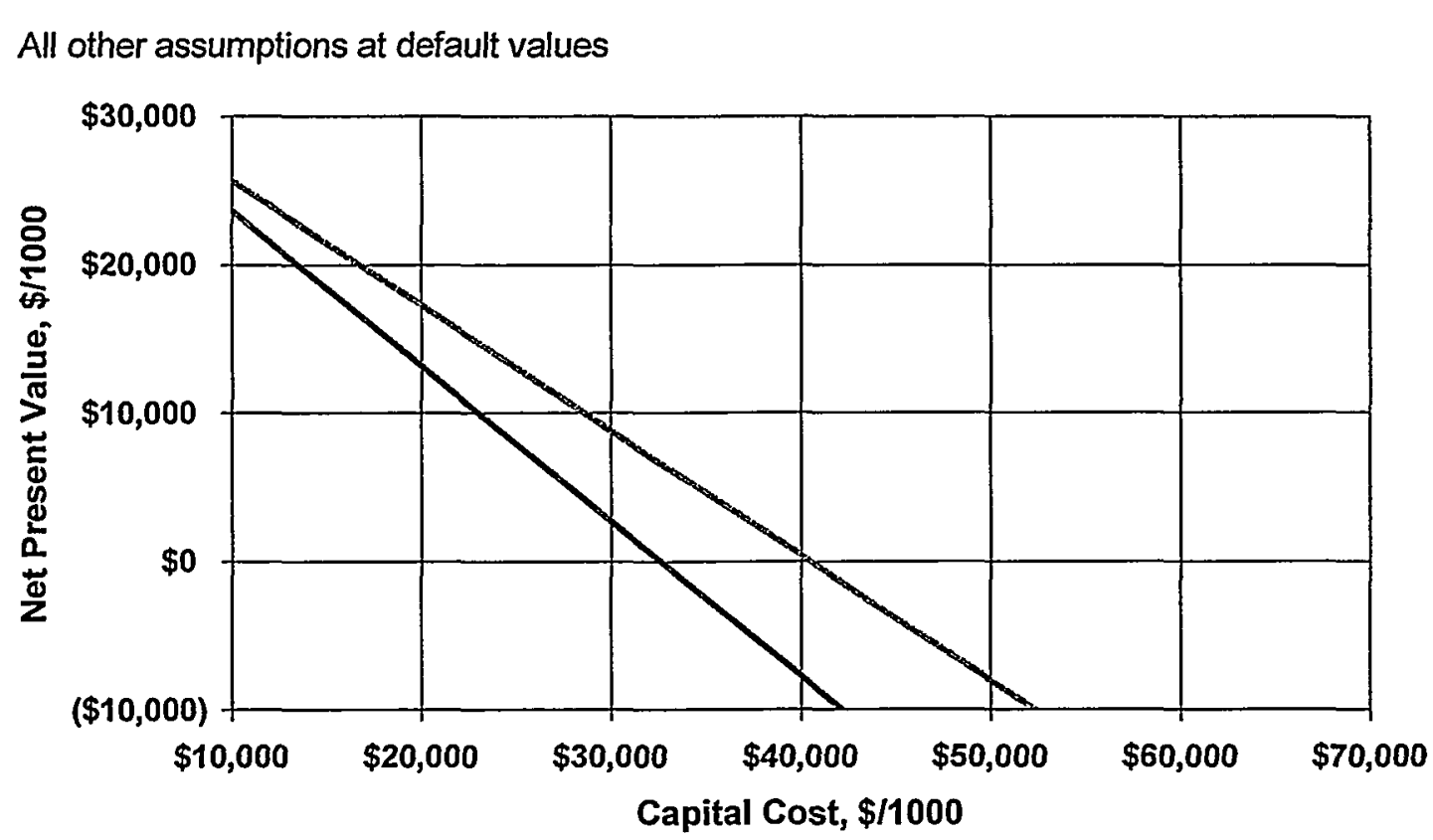

- Default Economic Assumptions- 5 Year DDB Depreciation, 15\% Investment Tax Credit

- 15 Year DDB Depreciation, 5\% Investment Tax Credit

Figure 9-12: Impact of Preferential Tax Treatment on Net Present Value 


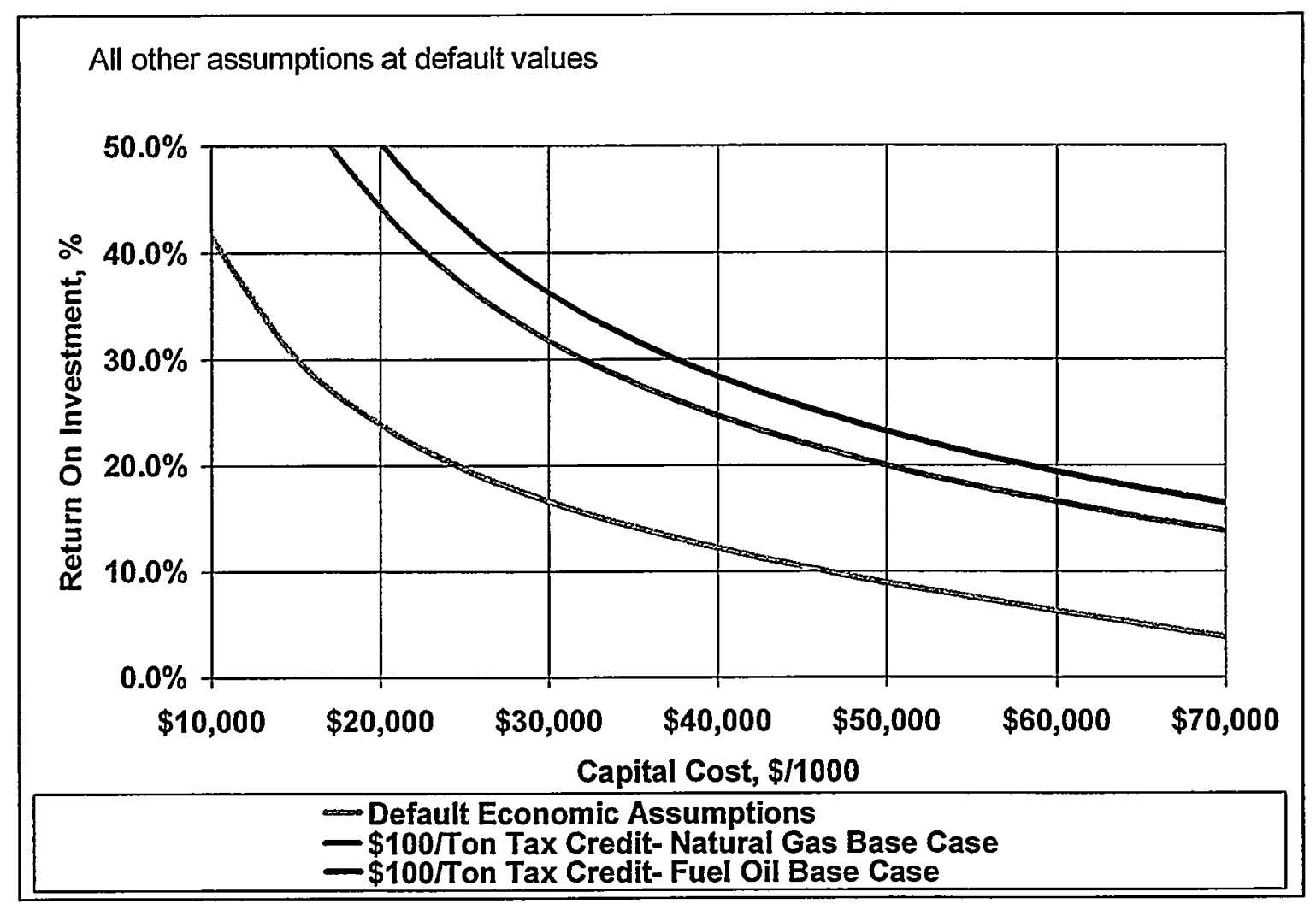

Figure 9-13: Impact of Tax Credits for Avoided Carbon Emissions on Return on Investment

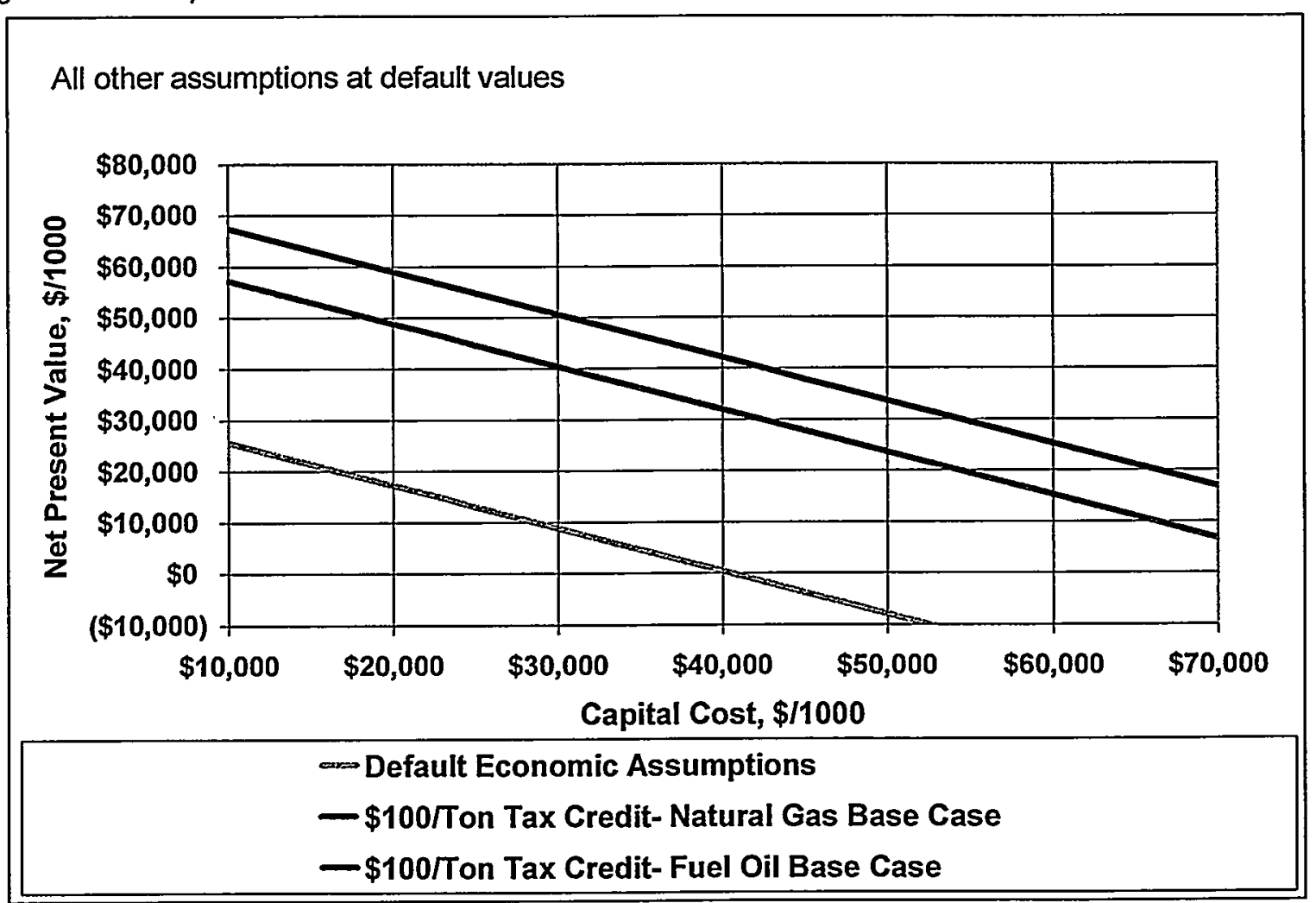

Figure 9-14: Impact of Tax Credits for Avoided Carbon Emisisons on Net Present Value 
All other assumptions at default values

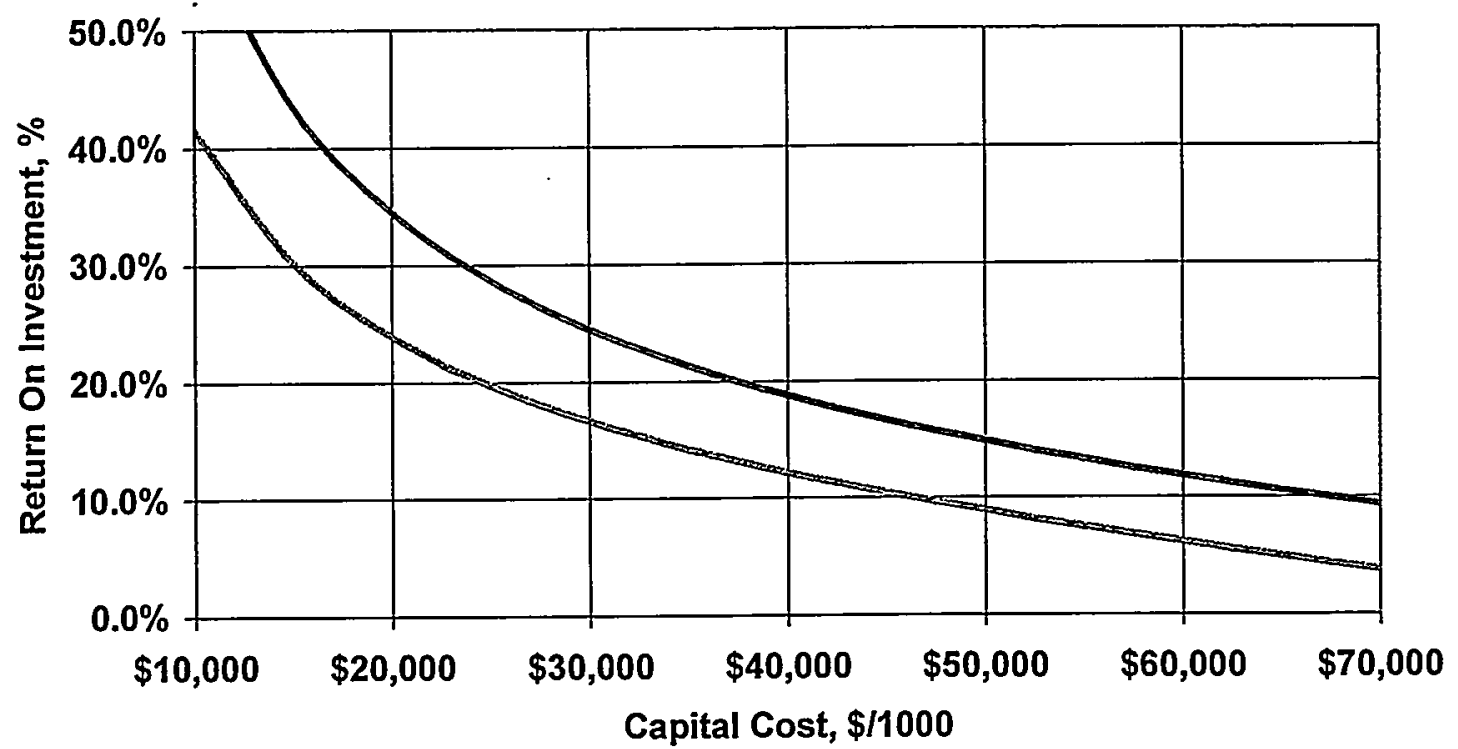

Default Economic Assumptions - With \$1.00/Mbtu Biomass Gas Tax Credit

Figure 9-15: Impact of Fuel Gas Tax Credit on Return on Investment

All other assumptions at default values

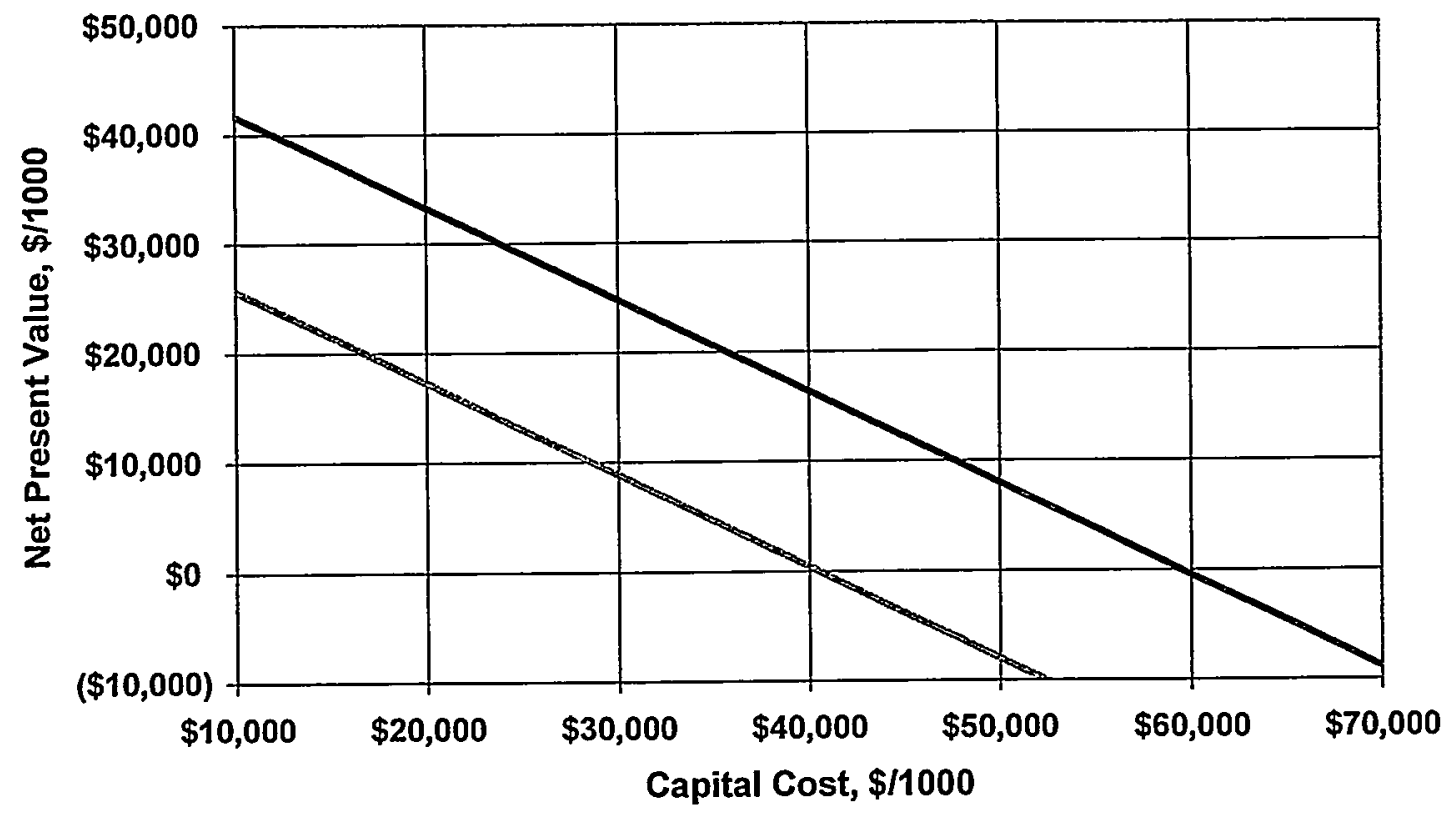

Default Economic Assumptions - With \$1.00/Mbtu Biomass Gas Tax Credit

Figure 9-16: Impact of Fuel Gas Tax Credit on Net Present Value

BGCC Project Final Report

DE-FC36-96G010173 
As in the New Bern cases, a range of ROI "hurdle rate" values from $12 \%$ to $19 \%$ has been defined to represent the minimum threshold required for project economic viability. In Table 9-3, below, supportable capital for the generic LIVG project is displayed as a function of biomass and fossil fuel prices.

\begin{tabular}{|c|c|c|c|c|c|c|}
\hline & \multicolumn{2}{|c|}{ Fossil Fuel, $\$ 3.00 / \mathrm{MBu}$} & \multicolumn{2}{|c|}{ Fossil Fuel, $\$ 4.00 / \mathrm{MBui}$} & \multicolumn{2}{|c|}{ Fossil Fuel, $\$ 5.00 \mathrm{MBiu}$} \\
\hline $\begin{array}{l}\text { Biomass Fuel } \\
\text { Cost, \$/BDT }\end{array}$ & $\begin{array}{c}\text { Supportable } \\
\text { Capital @ } \\
19 \% \text { ROI }\end{array}$ & $\begin{array}{c}\text { Supportable } \\
\text { Capital @ } \\
12 \% \text { ROI }\end{array}$ & $\begin{array}{c}\text { Supportable } \\
\text { Capital @ } \\
\text { 19\% ROI }\end{array}$ & $\begin{array}{c}\text { Supportable } \\
\text { Capital @ } \\
\text { 12\% ROl }\end{array}$ & $\begin{array}{c}\text { Supportable } \\
\text { Capital @ } \\
\text { 19\% ROI }\end{array}$ & $\begin{array}{c}\text { Supportable } \\
\text { Capital @ } \\
12 \% \text { ROI }\end{array}$ \\
\hline$\$ 0 / B D T$ & $\$ 34,2 \mathrm{M}$ & $\$ 52.6 \mathrm{M}$ & $\$ 48.8 \mathrm{M}$ & $\$ 74.7 \mathrm{M}$ & $\$ 63.3 \mathrm{M}$ & $\$ 96.4 \mathrm{M}$ \\
\hline$\$ 10 / \mathrm{BDT}$ & $\$ 26.14$ & $\$ 40.2 \mathrm{n}$ & $\because \$ 40,6 \mathrm{M}$ & $\$ 62.5 \mathrm{M}$ & $\$ 55.1 M$ & $\$ 84.5 \mathrm{M}$ \\
\hline \$20/BDT & $17.9 M$ & $\$ 28.2 M$ & $\$ 32.4 M$ & $\$ 50.4 \mathrm{M}$ & $\$ 46.9 \mathrm{M}$ & $\$ 72.4 \mathrm{M}$ \\
\hline$\$ 30 / B D T$ & $\$ 9.7 M$ & $\$ 16.1 M$ & $\$ 24.2 \mathrm{~N}$ & $\$ 381 M$ & $\$ 387 \mathrm{M}$ & $\$ 60.3 M$ \\
\hline
\end{tabular}

Table 9-3: Supportable Capital Summary

Generic system capital $(\$ 49.9 \mathrm{M})$ is supportable in unshaded portion of table. As expected, greater spread in fossil vs. biomass fuel pricing increases the supportable investment in the technology. Similarly, decreasing investor expectations with regard to return on investment also increase the level of supportable investment.

Figures 9-9 and 9-10 address the impact of capacity utilization. In the default case, the project operates at $80 \%$ of design rating for a 355 day annual operating schedule. In all cases, it is assumed that fossil fuel is fired $4 \%$ of the time due to gasifier island downtime. As is typical of any solid fuel utilization technology, this process lends itself to highutilization or base loaded applications in order to justify the capital expenditure.

Figures 9-11 and 9-12 show the impact of changing project depreciation schedule from five year DDB to fifteen year DDB and removing the $15 \%$ tax credit assumed to be available for biomass projects. As seen in Figure 9-11, these measures increase the supportable investment in the generic project by $\$ 6$ million to $\$ 9$ million.

The impact of potential renewables or carbon emission-related public policy incentives to encourage biomass utilization is displayed in Figures 9-11 through 9-16. In Figures 9-11 and $9-13$, it is seen that-given the default economic assumptions-these policy incentives bring project returns into the threshold range at the $\$ 50$ million capital investment estimated to be necessary for the generic case. Table $9-4$ displays public policy incentive values needed, given the default economic assumptions, to bring project viability (as measured by ROI) into an acceptable range. 


\begin{tabular}{|c|c|c|}
\hline 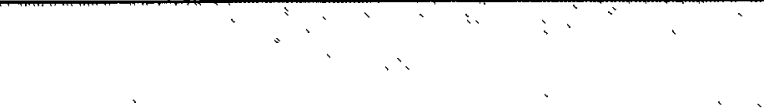 & $\begin{array}{l}\text { Generic Plant } \\
\text { "Nth Plant" Capital }\end{array}$ & $\operatorname{cost}=-\$ 50.0 \mathrm{M}$ \\
\hline PARAMETER & Value for $12 \% \mathrm{ROI}$ & Value for $19 \%$ ROI \\
\hline $\begin{array}{l}\text { Fuel gas tax credit, } \$ / \mathrm{MBtu} \\
\text { (based on higher heating value of product gas) }\end{array}$ & $\$ 0.49$ & $\$ 1.77$ \\
\hline $\begin{array}{l}\text { Tax credit for avoided atmospheric carbon } \\
\text { emissions, \$/ton avoided carbon emission } \\
\text { Natural Gas as Base Case Fuel }\end{array}$ & $\$ 24.87$ & $\$ 89.85$ \\
\hline $\begin{array}{l}\text { Income from taxable emission credit for avoided } \\
\text { atmospheric carbon emissions, } \$ \text { /ton avoided } \\
\text { carbon emission } \\
\text { Natural Gas as Base Case Fuel }\end{array}$ & $\$ 40.11$ & $\$ 144.91$ \\
\hline $\begin{array}{l}\text { Tax credit for avoided atmospheric carbon } \\
\text { emissions, \$/ton avoided carbon emission } \\
\text { \#6 Fuel Oil as Base Case Fuel }\end{array}$ & $\$ 18.85$ & $\$ 68.08$ \\
\hline $\begin{array}{l}\text { Emission credit (taxable) for avoided } \\
\text { atmospheric carbon emissions, } \$ \text { /ton avoided } \\
\text { carbon emission } \\
\text { \#6 Fuel Oil as Base Case Fuel }\end{array}$ & $\$ 30.40$ & $\$ 109.80$ \\
\hline Capital Cost Support (One Time Payment), \$ & $\$ 9.5 \mathrm{M}$ & $\$ 23.9 \mathrm{M}$ \\
\hline
\end{tabular}

Table 9-4: Level of Public Policy Incentive to Reach Threshold Rate of Return

As can be seen in the table, the magnitude size of public policy-based incentives are lower for the generic case than for the analogous incentives in the New Bern-specific case (see Table 8-4). This is due mainly to two differences between the generic and the New Bern cases: 1) the wider spread between fossil fuel and biomass fuel pricing in the generic case, and 2) the lower capital cost inherent in defining the generic case. Also noted above, the magnitude of carbon-based incentives will have to be larger in cases where natural gas is displaced due to the lower carbon emissions from natural gas firing.

\subsection{Conclusions}

In the absence of public policy incentives, the generic LIVG project looks economically attractive for combinations of high avoided fossil fuel price and low biomass fuel price as shown in Table 9-3. Given the default economic assumptions used in this analysis, which includes an avoided fossil fuel price of $\$ 3.00 / \mathrm{MBtu}$, investment in the generic LIVG project is warranted only at very low market values for biomass fuels. Investment would only be warranted at the low end of the defined threshold range of project ROI. This range of return 
would likely be attractive to investors only for well proven process technologies used where future revenue streams are well understood (such as in the independent power production projects being developed today). Given that the generic project represents an "Nth Plant" situation, additional incentives - such as significant "buy down" of capital cost-will most likely be necessary for early applications of the technology.

Public policy incentives typical of those used today to encourage biomass use (e.g., accelerated depreciation schedules, modest investment tax credits) have a significant impact on the economic performance of projects such as this one (see Figures 9-11 and 9-12). However, given the default assumptions used here, they would not be sufficient to support project implementation except where biomass fuels were free or where a disposal problem exists.

Public policy incentives which give economic recognition to the value of renewable fuels or to the avoidance of atmospheric carbon emissions are likely to play a key role in the viability of technologies such as the LIVG process. This is certainly true in the current technology development phase. Whether it is also true given commercially proven process technologies depends on the future direction of fossil fuel prices. 


\title{
Section 10
}

\author{
Overall \\ Conclusions
}

(

I

( 


\subsection{Overall Conclusions}

Gasification combined cycle continues to represent an important defining technology area for the forest products industry. The "Forest Products Gasification Initiative", organized under the Industry's Agenda 2020 technology vision and supported by the DOE "Industries of the Future" program, is well positioned to guide these technologies to commercial success within a five- to ten-year time frame given supportive federal budgets and public policy.

Commercial success will result in significant environmental and renewable energy goals that are shared by the Industry and the Nation.

The Battelle/FERCO LIVG technology, which is the technology of choice for the application reported here, remains of high interest due to characteristics that make it well suited for integration with the infrastructure of a pulp production facility. The capital cost, operating economics and long-term demonstration of this technology are a key input to future economically sustainable projects and must be verified by the $200 \mathrm{BDT} /$ day demonstration facility currently operating in Burlington, Vermont.

The New Bern application that was the initial objective of this project is not currently economically viable and will not be implemented at this time due to several changes at and around the mill which have occurred since the inception of the project in 1995.

The analysis shows that for this technology, and likely other gasification technologies as well, the first few installations will require unique circumstances, or supportive public policies, or both to attract host sites and investors.

Examples of supportive public policies are:

- Tax credits for biomass gas production (\$0.50/MBtu or higher)

- Tax credits for avoided atmospheric carbon emissions ( $\$ 25 /$ ton avoided carbon or higher)

- Capital cost support for the first 2-3 plants (50\% or greater)

- Flexibility of EPA rules and permitting procedures to allow for time to implement and time to develop alternative solutions in the event of technology failure

Examples of unique circumstances are:

- High non-recovery fuel cost (\$3.00/MBtu or greater)

- High electric power value $(\$ 0.05 / \mathrm{kWh}$ or greater

- Low wood residual cost (\$10/BDT or lower)

- Disposal costs or issues

- Aging power infrastructure that requires replacement or major relifing costs

These policy and circumstance areas are not mutually exclusive, nor will one area alone justify a project. It is likely that a number (but not all) of the above will have to work together to make the first few projects economically sustainable and interesting enough to justify the risk and attract the investors.

Weyerhaeuser continues to support the development and commercialization of gasification combined cycle technologies in general, and the Battelle/FERCO LIVG technology specifically, in order that they may become viable commercial choices for Weyerhaeuser and the Industry within the current decade. 